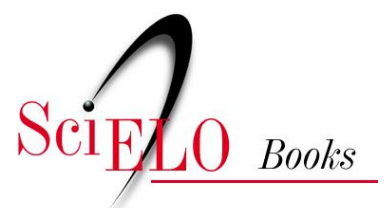

\title{
Participação e saúde no Brasil
}

\author{
Soraya Vargas Côrtes (org.)
}

CÔRTES, SV., org. Participação e saúde no Brasil [online]. Rio de Janeiro: Editora FIOCRUZ, 2009.

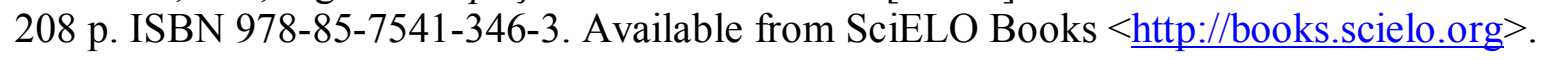

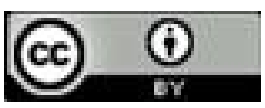

All the contents of this work, except where otherwise noted, is licensed under a $\underline{\text { Creative Commons Attribution } 4.0}$ International license.

Todo o conteúdo deste trabalho, exceto quando houver ressalva, é publicado sob a licença Creative Commons Atribição $\underline{4.0}$.

Todo el contenido de esta obra, excepto donde se indique lo contrario, está bajo licencia de la licencia $\underline{\text { Creative Commons }}$ Reconocimento 4.0. 
PARTICIPAÇÁO e SAÚdE NO BRASIL 


\section{FUNDAC̣ÃO OSWALDO CRUZ}

Presidente

Paulo Ernani Gadelha Vieira

Vice-Presidente de Ensino,

Informação e Comunicação

Maria do Carmo Leal

\section{EDITORA FIOCRUZ}

\section{Diretora}

Maria do Carmo Leal

Editor Executivo

João Carlos Canossa Mendes

Editores Científicos

Nisia Trindade Lima

Ricardo Ventura Santos

Conselho Editorial

Ana Lúcia Teles Rabello

Armando de Oliveira Schubach

Carlos E. A. Coimbra Jr.

Gerson Oliveira Penna

Gilberto Hochman

Joseli Lannes Vieira

Lígia Vieira da Silva

Maria Cecilia de Souza Minayo 
PARTICIPAÇÁO E SAÚdE

y Vargas Cortes

EDTORA 
Copyright (C) 2009 dos autores

Todos os direitos desta edição reservados à

FUNDAÇÃO OSWALDO CRUZ/ EDITORA

ISBN: 978-85-7541-176-6

Capa, projeto gráfico

Carlota Rios

Revisão e copidesque

Jorge Moutinho

Normalização de referências

Clarissa Bravo

Supervisão Editorial

M. Cecilia Gomes Barbosa Moreira

Catalogação na fonte

Centro de Informação Científica e Tecnológica

Biblioteca da Escola Nacional de Saúde Pública Sergio Arouca

C828p Côrtes, Soraya Vargas (Org.)

Participação e Saúde no Brasil. / organizado por Soraya

Vargas Côrtes. - Rio de Janeiro: Editora Fiocruz, 2009.

208 p., tab., graf.

1. Conselhos de Saúde. 2. Participação Comunitária.

3. Sistema Único de Saúde. 4. Qualidade da Assistência à Saúde. I. Título.

CDD - 22.ed. - 362.10680981

2009

EDITORA FIOCRUZ

Av. Brasil, 4036 - sala 112 - Manguinhos

21040-361 - Rio de Janeiro - RJ

Tels: (21) 3882-9039 e 3882-9041

Telefax: (21) 3882-9006

editora@fiocruz.br

www.fiocruz.br/editora 


\section{AUTORES}

\section{Adriane Cristine Goldoni}

Socióloga, analista ambiental do Ministério do Meio Ambiente.

\section{Alcindo Antônio Ferla}

Médico, doutor em educação e saúde pela Universidade Federal do Rio Grande do Sul (UFRGS), pesquisador do Núcleo de Educação, Avaliação e Produção Pedagógica em Saúde da mesma universidade, professor dos Programas de Pós-Graduação em Psicologia Clínica e Social da Universidade Federal do Pará (UFPA) e de Cooperação Técnica entre o Instituto de Informação Cientifica e Tecnológica em Saúde da Fundação Oswaldo Cruz (Icict/ Fiocruz) e o Grupo Hospitalar Conceição (GHC).

\section{Elisabete Oliveira Pereira}

Socióloga, mestre em sociologia pela Universidade Federal do Rio Grande do Sul (UFRGS).

\section{Fernando Canto Michelotti}

Graduado em odontologia, mestre e doutorando em sociologia na Universidade Federal do Rio Grande do Sul (UFRGS).

\section{Janete Cardoso Réos}

Socióloga, mestre e doutoranda em sociologia na Universidade Federal do Rio Grande do Sul (UFRGS) e assessora da Central Única dos Trabalhadores do Rio Grande do Sul.

\section{Liege Adamski dos Santos}

Socióloga, assessora de planejamento e gestão estratégica da Secretaria Municipal de Assistência, Cidadania e Inclusão Social do município de São Leopoldo (RS).

\section{Lisiane Bôer Possa}

Fisioterapeuta e sanitarista, mestre e doutoranda em sociologia na Universidade Federal do Rio Grande do Sul (UFRGS), gerente de Ensino e Pesquisa do Grupo Hospitalar Conceição (GHC). 


\section{Lúcia Inês Schaedler}

Pedagoga, mestre em educação pela Universidade Federal do Rio Grande do Sul (UFRGS), pesquisadora do Núcleo de Educação, Avaliação e Produção Pedagógica em Saúde da UFRGS.

\section{Marcelo Kunrath Silva}

Sociólogo, doutor em sociologia pela Universidade Federal do Rio Grande do Sul (UFRGS), professor do Departamento de Sociologia e dos Programas de Pós-Graduação em Sociologia e Desenvolvimento Rural da UFRGS.

\section{Márcio Barcelos}

Sociólogo, mestrando em sociologia na Universidade Federal do Rio Grande do Sul (UFRGS).

\section{Soraya Vargas Côrtes (organizadora)}

Socióloga, doutora em politicas sociais pela London School of Economics and Polical Science, professora do Departamento de Sociologia e dos Programas de Pós-Graduação em Sociologia da Universidade Federal do Rio Grande do Sul (UFRGS), pesquisadora do Conselho Nacional de Desenvolvimento Científico e Tecnológico (CNPq)

\section{Teresa Borgert Armani}

Pedagoga, sanitarista, mestre e doutora em educação pela Universidade Federal do Rio Grande do Sul (UFRGS), pesquisadora do Núcleo de Educação, Avaliação e Produção Pedagógica em Saúde da UFRGS. 


\section{SUMÁRIO}

PREFÁCIO

APRESENTAC̣̃̃o

Introdução: atores, mecanismos e dinâmicas participativas

Soraya Vargas Côrtes

1. Conselho Nacional de Saúde: histórico, papel institucional e atores estatais e societais

Soraya Vargas Côrtes, Marcelo Kunrath Silva, Janete Cardoso Réos e Márcio Barcelos

2. A Dinâmica das Relações Sociais no Conselho Nacional de Saúde 73 Marcelo Kunrath Silva, Soraya Vargas Côrtes, Janete Cardoso Réos e Márcio Barcelos

3. Conselho Estadual de Saúde do Rio Grande do Sul:

histórico, funcionamento, atores e dinâmica das relações sociais 111 Elisabete Oliveira Pereira, Soraya Vargas Côrtes e Márcio Barcelos

4. Conselhos Municipais de Saúde da Região Metropolitana de Porto Alegre: funcionamento, atores e dinâmica das relações sociais

Soraya Vargas Côrtes, Fernando Canto Michelotti, Adriane Cristine Goldoni e Liege Adamski dos Santos 
5. Mecanismos de Participação em Hospitais do Ministério da Saúde

Alcindo Antônio Ferla, Lisiane Bôer Possa, Teresa Borgert Armani, Lúcia Inês Schaedler e Soraya Vargas Côrtes

6. Uma Síntese do Debate sobre os Mecanismos e as Dinâmicas Participativas no Sistema Único de Saúde Soraya Vargas Côrtes 


\section{PREFÁCIO}

Participação e Saúde no Brasil cumpre o importante papel de iluminar o tema da participação social na saúde, ainda hoje pouco explorado na abordagem acadêmica, fornecendo, portanto, uma substantiva contribuição à ampliação de conhecimentos à saúde coletiva. Partindo de um conjunto de pesquisas sobre a participação social institucionalizada no Sistema Único de Saúde (SUS), especificamente os conselhos de saúde das instâncias federativas, inclui os conselhos gestores ou de gestão participativa das unidades que integram a rede de serviços.

A relação da saúde com a democracia está nas raizes do movimento da Reforma Sanitária, como pode ser constatado no título do documento considerado como base desse processo, lançado pelo Centro Brasileiro de Estudos da Saúde (Cebes) em 1979: "A questão democrática na área da saúde no Brasil”, ou simplesmente "A questão democrática da saúde", como também é conhecido.

O que se preconizava era o direito à saúde como integrante dos direitos humanos, cuja abrangência universal, por seu lado, constitui condição essencial para a consolidação da democracia. Numa equação linear simplificada, o esperado no debate na época era que, por meio da estimulação da participação dos usuários do sistema de saúde, houvesse uma crescente influência destes nos processos decisórios, resultando na ampliação da oferta e da qualidade dos serviços para a população.

Vale ressaltar que, desde sempre, o movimento da Reforma Sanitária teve claro que não apenas a oferta universal de serviços de saúde concretizasse o direito de todos, mas estava subjacente a idéia de que também a sociedade se responsabilizasse e participasse das decisões, garantindo por 
essa via a preservação dos interesses coletivos. $\mathrm{O}$ que se vislumbrava era um crescente nível de politização da sociedade com gradativa ampliação da consciência sanitária, ou seja, da consciência sobre o direito à saúde e sobre a cidadania. E para isso a institucionalização dos conselhos e das conferências constituiria estratégia fundamental.

Dessa 'generalização' da consciência sanitária surgiriam as bases de um novo paradigma do pensar e fazer a saúde no país, alicerçado na concepção da determinação social da saúde. O novo paradigma incluiria a criação e o alastramento de novos compromissos éticos entre os trabalhadores do setor. Usuários e trabalhadores deveriam, nesse contexto, estabelecer um processo de negociação permanente, buscando a composição de um arco sólido de alianças políticas e de atuação para a garantia do direito universal à saúde.

Apesar da fragilidade dessa concepção acerca do processo de determinação social da saúde no cenário atual do SUS, é sempre oportuno relembrar a importância atribuída às condições sociais, ambientais e econômicas na produção de determinado nível de saúde coletiva. Essa é a base do chamado conceito ampliado de saúde, e é a justificativa de o texto constitucional que institui a saúde como direito universal e dever do Estado ter inserido a saúde como um dos pilares do sistema de seguridade social. Situada assim, a saúde articularia as políticas solidárias e universalistas de proteção social. Para a atenção e o cuidado da saúde, foi criado o SUS com seu conjunto de princípios, entre os quais se destaca a participação da comunidade para a garantia da gestão democrática e do controle social sobre o sistema de saúde.

A legislação regulamenta os princípios constitucionais, definindo que a participação da sociedade na dinâmica do SUS seja institucionalizada nos conselhos e nas conferências de saúde. Os conselhos estaduais e municipais passam a ser condição de inclusão dos entes federados na gestão descentralizada do SUS, e sua criação é fortemente estimulada ao longo dos anos 90, de tal forma que existem hoje no Brasil conselhos de saúde na totalidade dos estados e dos municípios brasileiros.

$\bigcirc$ fato de existirem não garante que estejam em seu pleno funcionamento; pelo contrário: tais conselhos trouxeram consigo novos desafios a serem enfrentados na consolidação do SUS e de seus princípios. Coerente com as diferenças e desigualdades entre os diversos territórios e populações do país, o que prevalece é uma forte heterogeneidade entre esses conselhos quanto ao funcionamento e quanto à efetivação das práticas de participa- 
ção quando se analisa o conjunto de 5.560 municípios do país. Mesmo em municípios maiores, aparentemente comparáveis, há disparidades operacionais e politicas relacionadas aos conselhos de saúde.

Apesar da valorização legal das instâncias de participação e de controle social, particularmente, e da clara indução pela criação dos conselhos municipais e estaduais de saúde a partir das normas orientadoras da operacionalização do SUS - Norma Operacional Básica (NOB) e Norma Operacional de Assistência à Saúde (Noas) -, até 2003 não existia no SUS qualquer mecanismo de gestão para apoio a esses processos participativos. Nessa perspectiva, salvo iniciativas isoladas, não se realizou nenhuma ação sistematizada e contínua voltada para a qualificação permanente dos conselhos, que agora acumulam, na sua agenda obrigatória, a aprovação de planos e de relatórios de gestão de sua instância gestora.

Em 2003, resolve-se criar no Ministério da Saúde um setor específico para apoiar a gestão participativa, o que favoreceu a maior presença dessa temática orientando iniciativas inovadoras, ou mesmo as análises realizadas sobre a saúde coletiva nos país. No entanto, a criação de um setor que trata da gestão participativa permitiu a articulação e o financiamento de alguns grupos de pesquisadores interessados na realização de estudos sobre a participação no SUS, como é o caso das pesquisas que serviram de base para este livro.

Marcando avanços nessa área, é relevante dizer que atualmente o SUS já dispõe de um Sistema Nacional de Informações sobre Conselhos e Conselheiros de Saúde, o qual permite conhecer aspectos de extrema relevância sobre a constituição e o funcionamento dessas instâncias. Dados preliminares desse sistema, que recebeu o nome de ParticipaNetSUS, dão conta da longa estrada à frente para atingir a prevalência de indicadores mais aproximados ao pleno grau de funcionamento dos conselhos. Tais indicadores derivam da consideração de variáveis relacionadas a infra-estrutura, composição e funcionamento, possibilitando aproximações que informam sobre a autonomia e a democratização nos conselhos.

O que o leitor encontrará aqui, entretanto, são estudos de caso por meio dos quais se descortina um leque de achados inusitados, revelando dinâmicas negociais vivas, relações de poder, fortalezas e fragilidades de um processo que merece a atenção de todos. Sua leitura mostra a presença de poder concentrado em grupos ou categorias de conselheiros, além de ou- 
tras situações que resvalam a democracia interna nessas instâncias colegiadas de participação. Porém, o que fica subjacente nas análises não é definitivamente uma desvalorização desses mecanismos instituídos de participação, mas os desafios que tais constatações provocam nos diversos atores do processo de construção do SUS.

Com a leitura de Participação e Saúde no Brasil, fica evidente a necessidade da retomada de determinados conceitos básicos. Por exemplo: que significado, limite e possibilidades tem, de fato, o ato de 'deliberar' dos conselhos? Este livro reúne ainda argumentos que justificam a existência, no interior desses conselhos, de processos comunicativos e deliberativos efetivos na construção de políticas comprometidas com o conjunto da população.

O sentimento que fica é o de que, a despeito dos notáveis avanços que no momento já podem ser contabilizados pela existência dos conselhos, ainda há um longo caminho a percorrer na consolidação da democracia participativa na saúde. Como é tradição, no campo da saúde coletiva, de uma rápida incorporação das práticas de serviços e de gestão das constatações e reflexões decorrentes da produção acadêmica, fica a esperança de que esta obra seja festejada pelos pesquisadores, conselheiros, gestores e demais leitores. Que eles se reconheçam ao longo de cada um dos textos e nas situações encontradas nas quais os pesquisadores mergulharam para compartilhar com todos nós esta leitura. Se assim for, sai fortalecida a utopia da democracia participativa no país.

Ana Maria Costa Médica, doutora em ciências da saúde pela Universidade de Brasília, vice-presidente do Centro Brasileiro de Estudos da Saúde (Cebes), diretora de Apoio à Gestão Participativa do Ministério da Saúde 


\section{APRESENTAÇÃO}

Este livro é dedicado ao exame de processos participativos na área de saúde no Brasil. $\mathrm{O}$ assunto é relevante na medida em que, ao longo das três últimas décadas, mecanismos participativos institucionalizaram-se em diversos momentos do processo de planejamento e implementação de políticas públicas e passaram a integrar estruturas gerenciais de organizações públicas em diversos países. Podem ser encontrados exemplos de abertura de canais participativos em várias áreas de política pública. A natureza da participação varia desde a mera escuta, consulta ou advocacia dos interesses de consumidores e de usuários individuais até o envolvimento ativo de participantes representando interesses organizados em comitês, comissões e conselhos. De acordo com a literatura, as principais razões para a criação desses mecanismos foram: a crise de legitimidade das formas tradicionais de representação de interesses nas democracias liberais; a forte demanda por maior participação direta dos cidadãos no processo político; e o estímulo de agências internacionais de desenvolvimento.

A escolha da área da saúde deveu-se ao fato de que, dentre as áreas de politica pública, esta foi a que mais intensa e precocemente incorporou mecanismos de participação, como atesta a criação de dispositivos participativos em sistemas de saúde de diversos países, já a partir da década de 1970. O fenômeno estava associado não apenas às pressões visando à remodelação das instituições públicas, mas também, e talvez principalmente, ao estímulo de agências internacionais de desenvolvimento à participação da comunidade. Elaborada pelo Fundo das Nações Unidas para a Infância (United Nations Children's Fund - Unicef) e pela Organização Mundial da Saúde (OMS), a Declaração dos Cuidados Primários de Saúde, de 1977, pode ser considerada 
como a contribuição mais significativa para a consolidação de políticas que promoviam a participação comunitária ou popular.

A Declaração recomendava a aplicação de tecnologias simplificadas por meio de um sistema de saúde hierarquizado que atingiria toda a população, embora tivesse como alvo prioritário os mais pobres. As políticas de cuidados primários de saúde deveriam ainda estimular o autocuidado e a autonomia das comunidades, mobilizando-as para que assumissem a responsabilidade por sua saúde. Havia o pressuposto de que o envolvimento das comunidades com os serviços de saúde poderia resultar no estabelecimento de um controle externo sobre burocracias relutantes em aceitar propostas de mudança ou reforma nos sistemas de saúde. As propostas da Declaração, dentre elas a que preconizava o envolvimento da comunidade em diferentes momentos do planejamento e implementação da atenção à saúde, transformaram-se em pontos básicos de agendas reformistas na área, tanto em países desenvolvidos como naqueles em desenvolvimento.

No Brasil, desde 1985 as experiências participativas chamam a atenção não apenas por causa da grande quantidade, mas também em razão de sua vitalidade, em termos de envolvimento de participantes, e de seu nível de disseminação pelo país e pelas diversas áreas de política social. Nesse contexto, a área da saúde se destaca pela precocidade com que nela se constituíram fóruns participativos, no mesmo processo que levou à integração e descentralização da gestão de serviços financiados com recursos públicos no país. Na segunda metade da década de 1980, foram criadas as comissões interinstitucionais de saúde - em níveis federal, estadual e municipal - por meio do Programa das Ações Integradas de Saúde, de 1984. O funcionamento das comissões foi fortalecido pelo Programa dos Sistemas Unificados Descentralizados de Saúde (Suds), em 1987. Essas comissões deram origem a conselhos de saúde, principal mecanismo de participação analisado ao longo do livro. $\mathrm{O}$ arcabouço legal e administrativo que, a partir de 1990, criou os conselhos e conferências de saúde e regulamentou seu funcionamento incidiu sobre um processo institucional, já em curso, de descentralização e implantação de mecanismos participativos.

Em 2006, ano em que foi finalizada a pesquisa empírica que deu origem aos dois estudos que tratam do Conselho Nacional de Saúde, este fórum estava em pleno funcionamento, e conselhos estaduais e municipais de saúde estavam formados em todos os estados e municípios do país. Desde 1990, 
vêm sendo criados conselhos gestores em unidades ambulatoriais e hospitalares, fóruns participativos em hospitais públicos, além de dispositivos que propiciam a participação individual por meio de mecanismos como o Disque-Saúde, pesquisas de satisfação de usuários e ouvidorias.

Observe-se que nos processos participativos analisados, quando ocorre a decisão política, ela envolve certos aspectos da política de saúde e não toda a política de saúde. As normas legais e administrativas do Sistema Único de Saúde (SUS) estabelecem a necessidade de participação, mas não constituem instâncias que substituiriam o espaço da gestão como principal centro decisório do sistema. Mesmo que a lei ou as normas estabeleçam que os conselhos são os locais nos quais se decidem as políticas de saúde, na prática isso não acontece. $O$ processo real de tomada de decisões é mais amplo, ocorrendo em diferentes espaços estatais e societais, envolvendo uma grande variedade de atores.

Assim, em vez de indagar se as decisões sobre as políticas de saúde são de fato tomadas nesses fóruns, os estudos aqui reunidos compartilham o interesse em compreender como atores estatais e societais participam nas atividades dos conselhos através dos mecanismos de participação dos hospitais e qual o papel dos conselhos e de tais mecanismos na arena política da área. Para responder às duas questões, foi necessário focalizar os processos políticos que se desenvolvem no interior dos fóruns examinados e na arena decisória da área da saúde. Para isso foi adotado um instrumental teórico comum, apresentado no capítulo introdutório, que é composto por um conjunto de conceitos articulados sobre participação, sobre atores que agem tanto em fóruns participativos como em outros espaços decisórios e sobre a natureza das relações entre Estado e sociedade.

O fato de o livro ser composto por estudos que buscam responder às mesmas questões e que adotam a mesma perspectiva teórico-conceitual tem uma explicação: ele é o resultado do esforço comum de uma equipe de pesquisadores que discutiu em conjunto as diversas etapas das pesquisas que informam os capitulos aqui reunidos. Entretanto, cada grupo de autores teve relativa autonomia para acentuar diferentes aspectos, levando em conta seus interesses e a natureza dos dados disponíveis.

Os objetos de investigação empírica analisados foram: o Conselho Nacional de Saúde, o Conselho Estadual de Saúde do Rio Grande do Sul (CES/RS), os conselhos municipais de Saúde da Região Metropolitana de 
Porto Alegre (RMPA) e os mecanismos de participação existentes em hospitais do Ministério da Saúde. Embora os dados disponiveis para análise não sejam exatamente da mesma natureza, os estudos sobre os conselhos procuram discutir as duas questões básicas aqui apresentadas. $\mathrm{O}$ exame dos mecanismos de participação nos hospitais do Ministério da Saúde teve objetivos bem mais modestos. Trata-se de um estudo pioneiro que descreve as formas de envolvimento de atores internos e externos existentes nessas organizações hospitalares. Mecanismos participativos são identificados, descritos e classificados em uma tipologia que focaliza, principalmente, os tipos de participantes envolvidos.

O livro está organizado em cinco capítulos de análise de dados empíricos, além da introdução e do capitulo final de conclusões. Após esta apresentação, a introdução apresenta o referencial teórico-conceitual utilizado pelo conjunto dos estudos que compõem a coletânea. $\mathrm{O}$ primeiro capítulo faz uma caracterização do Conselho Nacional de Saúde, por meio da reconstrução dos antecedentes históricos do Conselho e da análise das funções e da composição do fórum desde a sua criação. Para isso verificouse qual foi a evolução da proporção dos atores estatais e societais que eram legalmente conselheiros desde a criação do Conselho, em seu novo formato em 1990, até a mudança regimental ocorrida em 2006. O Conselho Nacional de Saúde também é tema do segundo capítulo. Nele é analisado o modo como se estruturam as relações entre os atores no interior do Conselho, verificando ainda qual a capacidade de influir ou, em outras palavras, qual o 'papel' do Conselho na arena decisória da área.

O capitulo 3 examina a dinâmica das relações entre os atores no interior do Conselho Estadual de Saúde do Rio Grande do Sul e a posição do Conselho na configuração das relações sociais da área de saúde naquele estado. No capitulo 4, faz-se, inicialmente, uma caracterização dos conselhos municipais de saúde da Região Metropolitana de Porto Alegre, quanto às suas condições de funcionamento e aos conselheiros participantes. Em seguida analisam-se a dinâmica de funcionamento dos fóruns, focalizando as relações entre os atores, e o papel institucional dos conselhos no contexto da política de saúde municipal. No capítulo 5, apresenta-se um estudo sobre mecanismos de participação nos hospitais vinculados diretamente ao Ministério da Saúde. O último capítulo traz uma síntese das principais conclusões derivadas dos estudos que integram o livro. 
As pesquisas que deram origem a Participação e Saúde no Brasil não teriam sido realizadas a contento se não fosse o apoio do Conselho Nacional de Desenvolvimento Científico e Tecnológico (CNPq) e da Secretaria de Gestão Participativa do Ministério da Saúde. Saliento, particularmente, o apoio e o incentivo constantes de Ana Maria Costa, diretora do Departamento de Apoio à Gestão Participativa daquela secretaria, e de Gilberto Hochman, pesquisador e professor da casa de Oswaldo Cruz, da Fundação Oswaldo Cruz. Merece menção também o ambiente acadêmico estimulante do Programa de Pós-Graduação em Sociologia da Universidade Federal do Rio Grande do Sul, ao qual a maior parte dos autores está vinculada. Espero que os textos aqui reunidos possam colaborar tanto para se compreenderem os mecanismos de participação, caracteristica já institucionalizada no modo de funcionamento das políticas públicas no país, como para inspirar a adoção de caminhos metodológicos inovadores e rigorosos na sua análise, o que considero que os estudos aqui reunidos o fizeram.

A Organizadora 



\section{INTRODUÇÃO:
ATORES, MECANISMOSE
DINAMMICAS PARTICIPATIVAS}

Soraya Vargas Côrtes

Os estudos reunidos neste livro analisam fóruns e mecanismos de participação da área da saúde no Brasil. A importância de examiná-los está diretamente relacionada à institucionalização de mecanismos participativos, ao longo das três últimas décadas, em diversos momentos do processo de planejamento e implementação de políticas públicas nas mais variadas áreas.

No final do regime militar, as pressões por mais participação afetavam todas as áreas de políticas públicas no Brasil. Ao mesmo tempo que se iniciavam reorganizações institucionais setoriais, diferentes atores politicos demandavam e propunham a democratização do sistema político. A área da saúde, em contraste com outras áreas, foi a que mais intensa e precocemente incorporou mecanismos de participação. Além disso, já no final dos anos 70, identificava-se a formação de uma comunidade de política, muito articulada, que defendia a democratização do acesso a serviços combinada à democratização da gestão em saúde. A comunidade, usualmente denominada movimento sanitário, viria a ter papel decisivo, não apenas na construção do Sistema Único de Saúde (SUS), mas também na definição do modo como a participação seria incorporada como elemento constituinte do desenho institucional do sistema. Assim, é possivel afirmar que os mecanismos de participação aqui analisados resultaram de processos gerais, 
transetoriais, de abertura de órgãos e instituições estatais ao escrutínio e demandas sociais, mas também, marcadamente na área da saúde, da ação de diversos atores sociais, estatais e do movimento sanitário, que reunia membros oriundos tanto da sociedade civil quanto do Estado.

Idealizadores e participantes desses mecanismos - bem como seus analistas - tinham a expectativa de que a articulação entre os gestores e burocracias governamentais, de um lado, e os interesses de trabalhadores, usuários e beneficiários de políticas públicas, de outro, afetaria positivamente a sensibilidade dos governos às demandas por democratização do acesso a serviços e bens. Esperavam também que, desse modo, as burocracias estatais viessem a se responsabilizar por suas ações, ou seja, que se tornariam politicamente accountable ante seus atos. No entender dos analistas, interesses tradicionalmente excluídos do processo de decisão passariam a ser considerados, e gestores de políticas públicas e burocracias governamentais seriam induzidos a tomar decisões levando em conta tais interesses. Embora houvesse discordância sobre a natureza dos interesses representados e do processo político que ocorria nesses fóruns, havia concordância sobre sua importância em países em desenvolvimento, como o Brasil, para promover a boa governança e reduzir as possibilidades de manutenção de padrões autoritários de decisão e de formas clientelistas de relação entre governos e atores sociais.

Recentemente, porém, tanto as análises acadêmicas quanto as avaliações dos atores envolvidos em tais experiências - governamentais ou da sociedade civil - têm indicado uma série de obstáculos vivenciados no cotidiano dos fóruns participativos, no sentido de atingirem os objetivos inscritos no ideário normativo que fundamentou sua implantação. De modo mais ou menos explícito, ao avaliar a natureza da participação em conselhos de saúde ou em outros mecanismos participativos, utilizaram-se como parâmetro analítico as regras legais que estabelecem que neles 'devem' ser tomadas as principais decisões políticas relativas à área social a que estão afetos. É possivel indagar sobre a validade de utilizar como referência para análise da natureza da participação normas legais administrativas que estabelecem que eles 'são' os fóruns decisórios.

Dois problemas teórico-metodológicos podem ser identificados nesse tipo de abordagem. Em primeiro lugar, há o risco de se chegar sempre à conclusão de que tais mecanismos não são deliberativos, de que as deliberações ocorrem em outros espaços políticos ou, na melhor das hipóteses, de 
que maior ou menor proporção das decisões acontece fora dos espaços colegiados de decisão. Esse tipo de conclusão - que se pode antecipar não elucida o papel que conselhos ou outros mecanismos participativos estão, de fato, cumprindo no contexto das políticas públicas do país. Também não favorece o conhecimento da natureza dos processos sociais e políticos participativos que neles ocorrem. Permite apenas que se verifique, novamente, o quanto estão enraizados, na cultura política das instituições públicas brasileiras, padrões de comportamento tradicionais, clientelistas, autoritários ou mesmo patrimonialistas. Não são passiveis de contestação as fortes evidências de pesquisa que demonstram a permanência de tais padrões de decisão sobre políticas públicas. Entretanto, esse tipo de abordagem obscurece a compreensão do que mecanismos de participação institucionalizados apresentam de novidade, de mudança em relação aos padrões estruturados de relação entre Estado e sociedade civil no país.

Em segundo lugar, ao elevar uma diretriz legal administrativa ao estatuto de parâmetro metodológico, entra-se em contradição com proposições teóricas e evidências empíricas. As normas estabelecidas em lei ou por decisões administrativas em níveis federal, estadual e municipal se constituem em dispositivos normativos que evidenciam o desejo de mudança do legislador ou do formulador da norma. As regras que de fato estruturam a maneira como se estabelecem as relações sociais e o processo de decisão sobre políticas públicas em sociedades contemporâneas são constituídas por um conjunto de outros condicionantes. Existem outras influências normativas, além da legal e administrativa; há a permanência de regras tradicionais de ação e a relação entre atores e há que se considerar que os atores envolvidos refletem sobre oportunidades abertas ou caminhos fechados para a defesa de suas propostas. Além disso, as teorias do Estado podem considerar que o processo decisório ocorre de modo mais ou menos difuso ou, então, podem atribuir ao poder estatal maior ou menor autonomia ante os interesses societais, mas não existe discordância em relação à impossibilidade de se conceber a deliberação sobre políticas como ocorrendo em um único lócus. E é indiferente, no caso, que se considere deliberar no sentido de decidir ou de discutir.

O emprego de parâmetros analíticos inadequados tem levado freqüentemente à constatação de que os mecanismos participativos, especialmente os conselhos, criados desde 1990, no Brasil, não são deliberativos 
e que as relações de poder em seu interior são marcadamente assimétricas. Tais conclusões pouco colaboram para elucidar o papel que esses fóruns efetivamente cumprem no contexto das políticas públicas setoriais, marcadamente na área da saúde, e qual a configuração de relações sociais que se estruturam em seu interior. Mesmo reconhecendo que eles não são 'o' lugar de deliberação, pode-se indagar em que medida e de que modo eles participam das decisões politicas setoriais e como os atores societais e estatais se relacionam e agem no interior desses fóruns.

Os capítulos que integram este livro, os quais tentam responder a tais indagações, compartilham uma dada perspectiva teórica sobre a natureza das relações entre Estado e sociedade, que é explicitada a seguir. Inicialmente, discutem-se os conceitos de atores estatais e societais e de mecanismos participativos. Em seguida, analisam-se os tipos de participantes - sejam eles estatais, sejam societais - que a literatura aponta como os mais influentes no processo decisório da área de saúde. Entretanto, existem atores que não respeitam as fronteiras entre Estado e sociedade. Por isso, na seção seguinte, examinam-se as noções de comunidades de políticas (policy communities) agindo em contextos de redes de políticas (policy networks).

\section{Atores Estatais e Societais e Mecanismos PARTICIPATIVOS}

A noção de participação não apresenta um significado único. Ao contrário, sua polissemia tem provocado um intenso debate na literatura especializada em ciência política, em movimentos sociais, em desenvolvimento e em política de saúde. Autores tentaram classificar a natureza dos processos participativos por meio de tipologias que categorizaram os tipos de envolvimento de participantes no processo de decisão política (Lee $\&$ Mills, 1985), as diferentes atitudes ou propósitos das instituições ao promover processos participativos (Ham, 1980; Paul, 1987) e os diversos graus de envolvimento dos participantes (Arnstein, 1969). As classificações admitem ser teoricamente possível a existência de um processo participativo que provoque repartição de poder. Este é o caso das noções de colaboração, de negociação e de participação, na tipologia de Lee \& Mills (1985). É igualmente o caso do conceito de negociação, de acordo com a definição de Ham (1980), dos projetos ou políticas que visem ao 'empoderamento', 
segundo Paul (1987), e dos três degraus finais da clássica 'escada da participação', construída por Arnstein (1969). Neste livro, no entanto, o termo participação é utilizado no mesmo sentido que Lee \& Mills (1985) atribuem à noção de envolvimento: como um conceito genérico que deve ser qualificado para que se elucidem os diversos graus de participação.

Em contraste com a maioria dos trabalhos sobre o tema (Côrtes, 1995; Labra \& Figueiredo, 2002; Raichelis, 2000; Tatagiba, 2002; Valla, 1998), aqui não se consideram os usuários, classificação adotada pela legislação, ${ }^{1}$ como os atores cuja participação deve ser examinada. ${ }^{2}$ Os estudos que compõem Participação e Saúde no Brasil partem do pressuposto de que o conceito de usuário de serviços, assim como o de consumidor, é inadequado para analisar as relações sociais que se estabelecem pelos mecanismos examinados. A noção é derivada do campo da economia e se refere a indivíduos que usam bens ou serviços que são oferecidos por diferentes vendedores e prestadores. Embora a relação vendedor/comprador, típica no uso da noção de consumidor, não seja sua principal característica, o conceito de usuário se refere especificamente àqueles que usam determinados serviços prestados em uma dada área territorial. $\mathrm{O}$ conceito pode ser útil para análises gerenciais e administrativas sobre a natureza ou as condições de oferta de determinados serviços. Pode ainda ser empregado para designar os participantes em pesquisas de opinião e ouvidorias, como ocorre no capítulo 5, na análise de mecanismos de participação individual em hospitais. No entanto, não é um instrumento analítico adequado para a compreensão de processos políticos que envolvem atores coletivos. Tampouco favorece o entendimento das relações entre Estado e sociedade, sobre as quais tem se concentrado boa parte dos estudos sobre processos participativos (Dagnino, 2002; Dagnino, Olvera \& Panfichi, 2006; Lavalle, 2003; Silva, 2006). Por essas razões, utilizam-se os conceitos de atores estatais e societais ao se fazer referência àqueles que agem, em geral, representando interesses de órgãos públicos ou de governo no caso dos primeiros; ou representando interesses de coletividades ou particulares no caso dos segundos.

\footnotetext{
${ }^{1}$ A legislação estabelece que representantes do governo, de prestadores de serviço, de profissionais de saúde e de usuários são os participantes nos conselhos de saúde (Brasil, 1990, art. 1) e institui que metade dos conselheiros devem ser usuários (Brasil, 1990, art. 4).

${ }^{2}$ Exceção digna de nota são os estudos de Silva \& Labra (2001) que utilizam, como aqui, o conceito de atores sociais.
} 
Parte importante da literatura sobre as relações entre Estado e sociedade civil busca nas características das instituições explicações para os resultados de políticas e para a modelagem de identidades, interesses e estratégias dos grupos sociais (Amenta, 2005; Hall \& Taylor, 2003; Lowndes, 2002; Schmidt, 2005). Denominados neo-institucionalistas, esses autores atribuem aos aspectos sistêmicos e estruturais do Estado e ao desenho das organizações estatais a capacidade de moldar a ação de atores sociais e individuais (Goodwin, 2001; Steinmo, 1993). Um tipo de argumentação que integra esse conjunto, usualmente identificado como neo-institucionalismo histórico (Hall \& Taylor, 2003), destaca o papel de atores estatais e das relações destes com atores societais. A ação de articulações de atores estatais e societais, dependendo de sua autonomia e de suas capacidades, pode determinar os resultados das políticas (Evans, 1985; Skocpol, 1985). O neoinstitucionalismo histórico pode ser considerado como uma corrente peculiar, no conjunto formado pelo neo-institucionalismo, tendo em vista a ênfase que atribui ao papel dos atores estatais e às relações entre estes e atores societais.

Uma crítica feita às demais correntes do neo-institucionalismo é a acentuada preocupação com as instituições agindo, constrangendo, modelando ou induzindo a ação dos atores. Como afirmam Peters, Pierre e King (2005), a ênfase sobre a dependência de trajetória tem sido muito frutífera para explicar a persistência de determinadas políticas e fenômenos sociais, mas, para explicar mudanças políticas e trajetórias históricas institucionais de curto e médio prazos, é necessário mudar o foco do modelo analítico das estruturas para a ação, do estático para o dinâmico. Inovações institucionais, tais como conselhos de políticas públicas e orçamentos participativos, podem induzir a mudanças nas estratégias de organização e ação de atores sociais individuais e coletivos. Há, no entanto, potencialidades instituídas fora da esfera estatal, derivadas das relações que esses atores travam na esfera societal, que também influenciam decisões estratégicas. Atores societais refletem sobre as condições institucionais, sobre as possibilidades de ação, e fazem escolhas sobre as decisões mais apropriadas para a defesa de seus interesses e valores.

Assim, agrega-se à idéia de dependência de trajetória o pressuposto de que os atores, tanto estatais quanto societais, refletem e realizam escolhas, movidos por interesses, mas também por idéias e crenças por eles comparti- 
lhadas (Sabatier \& Jenkins-Smith, 1993). Seria difícil conceber mudanças institucionais e políticas que não fossem impulsionadas por um conjunto de idéias sobre arranjos e resultados políticos desejáveis, compartilhados por atores que exercem agência dirigindo a mudança (Peters, Pierre \& King, 2005).

Como Giddens (1989) argumenta, os seres humanos são agentes reflexivos. Os homens são responsáveis por suas ações, embora não possam ser responsabilizados pelas circunstâncias nas quais fazem suas escolhas. Quaisquer que sejam as circunstâncias, sempre há possibilidade de se optar entre alternativas. Saliente-se, no entanto, que o conceito de 'escolha', do modo como é utilizado por Giddens, sugeriria que o ator tem liberdade de opção e que não estaria fazendo suas escolhas imerso nas relações e redes sociais que ele integra (Hoggett, 2001). Hoggett sustenta que atores societais e estatais transformam-se em agentes e elaboram reflexões sobre as circunstâncias em que se encontram e sobre as melhores estratégias de ação a serem adotadas, imersos em contextos institucionais e politicos que limitam as possibilidades de escolhas estratégicas. Eles agem constrangidos e estimulados pelas relações e redes sociais que construíram ao longo de suas trajetórias politicas.

Apesar das críticas que provocaram (Archer, 1990, 1996; Hoggett, 2001; McAnnula, 2002), análises que focalizaram a ação humana, como a de Giddens, contrastam com aquelas das vertentes do neoinstitucionalismo que enfatizam, principalmente, estruturas e instituições como condicionantes da ação. A ênfase na noção de agência mostra a necessidade de se desenvolverem recursos teóricos para explicar a mudança social (Amenta, 2005).

A teoria político-institucional (Pierson, 1994; Skocpol, 1992; Weir, Orloff \& Skocpol, 1988) tem respondido aos desafios que a noção de agência e a necessidade de explicação da mudança têm apresentado. Esta teoria mantém o argumento de que as instituições estatais influenciam fundamentalmente a vida política, porém está atenta para a interação entre os atores (Amenta, 2005). Esses atores - estatais ou societais - são vistos agindo no contexto de constrangimentos institucionais, tentando influenciar politicas estatais. As investigações inspiradas nessa perspectiva procuram demonstrar a formação ou a agregação de grupos em torno de políticas; examinam a influência desses grupos na dinâmica política em torno delas e o seu curso (Amenta, 2005). 
O desafio de desenvolver recursos teóricos que incorporem as noções de agência e mudança é enfrentado também pelas perspectivas institucionalista-construcionista, de Hay (1996, 2002), e estratégicorelacional, de Jessop (1990, 2001). Esses autores atribuem nítida primazia às estruturas, mas procuram oferecer uma resposta sobre como atores políticos tornam-se agentes e empreendem mudanças. Eles consideram que os atores estatais e societais agem e se relacionam em contextos que apresentam constrangimentos institucionais e que favorecem certas estratégias em detrimento de outras (McAnulla, 2002).

Para Hay (2002), a noção de agência aparece na mesma perspectiva do neo-institucionalismo histórico: atores estatais determinando os resultados das politicas, atores estatais e societais articulando-se para determinar os resultados das políticas, ação condicionada pela combinação de legados históricos e situações conjunturais. A novidade de sua abordagem é que, para explicar como agentes empreendem mudanças, a ênfase analítica principal recai nas orientações estratégicas desses agentes e no modo de se relacionarem entre si e com o contexto institucional em que se encontram.

Jessop (2001), de maneira similar, argumenta que os poderes e as capacidades estatais não podem ser compreendidos focalizando o Estado isoladamente. A análise deve considerar, também, o contexto estratégico relacional. Para ele, em razão de sua seletividade estrutural e de suas capacidades estratégicas específicas, o poder estatal é sempre condicional e relacional. A realização desse poder depende dos laços estruturais entre o Estado e o sistema político que o engloba, das ligações estratégicas entre administradores estatais e outras forças políticas e do emaranhado complexo de interdependências e redes sociais que ligam o Estado e o sistema político ao ambiente societal mais amplo.

Neste livro, a perspectiva neo-institucionalista é adotada no sentido de considerar que as condições institucionais constrangem a ação dos atores. As instituições consideradas são as regras implícitas que regulam o funcionamento dos fóruns e mecanismos participativos que produzem os incentivos e constrangimentos à participação de atores societais. São também as regras que se constituíram na área da saúde no país que definiram o lugar desses mecanismos no contexto da política. Essas instituições alteram os modos de ação e organização de atores societais individuais e coletivos, mas são atores estatais, em relação com atores societais, que determinam 
resultados de políticas, mesmo que suas ações sejam condicionadas por legados históricos institucionais e por configurações societais particulares. As relações entre atores estatais e societais tanto podem ser conflitantes como também vir a se configurar mediante alianças entre aqueles que compartilham valores e concepções sobre quais devem ser os resultados de políticas. As articulações de atores, constituídas desse modo, têm como uma de suas características não serem limitadas pelas fronteiras entre Estado e sociedade.

Assim, é o conjunto formado pelo neo-institucionalismo histórico e as vertentes analíticas político-institucional, construcionista e estratégicorelacional que oferece os recursos analíticos que permitem aos estudos aqui apresentados focalizarem as redes de relações entre atores societais e entre estes e atores estatais. Atores estatais favorecem a agregação de grupos em torno de políticas, influenciando o processo político ao redor delas e seus resultados. Atores estatais e societais se defrontam com condições que constrangem e que favorecem suas ações e constroem suas estratégias com base em um número limitado de possibilidades. Identidades políticas são formadas, entre eles, na defesa de determinadas questões e interesses à medida que selecionam atores parceiros que ofereçam suporte para formulação e implementação de políticas de interesse comum.

As ações de atores estatais são decisivas na definição das condições de funcionamento de mecanismos participativos, porque eles podem ser acionados para o fortalecimento político de atores societais selecionados e para reforçar relações entre estes e os atores estatais. Ao contrário, conforme as circunstâncias, a importância relativa desses mecanismos no processo decisório pode ser reduzida, por meio de restrições orçamentárias ou da interposição de obstáculos para o seu pleno funcionamento. Assim, a configuração das relações entre atores estatais e societais define, em grande parte, os papéis institucionais que os mecanismos participativos aqui examinados podem ter no contexto da política de saúde ou das organizações, no caso dos hospitais, a que estão afetos.

A noção de configuração empregada é definida como redes interdependentes de seres humanos, com relações de poder assimétricas estruturadas e mutantes (Bergh, 1971). O conceito é relevante para os estudos deste livro porque, como Elias (1993) o propôs, ressalta a interdependência dos atores, sejam eles individuos, sejam grupos, em 
vez de salientar os antagonismos entre indivíduo e sociedade e entre grupos e instituições, como é prática recorrente nas análises entre Estado e sociedade.

Destaque-se ainda o valor heurístico do conceito para a "sociologia da emergência institucional” (Brandtstädter, 2000: 23). Os mecanismos de participação aqui examinados são novidades institucionais que, aos poucos, se consolidam como espaços nos quais se configuram e reconfiguram relações de poder existentes nas redes de interdependências sociais. Como afirma Brandtstädter (2000), a teoria de Elias ajuda a enxergar, no uso de uma abordagem diferente sobre as relações entre Estado e sociedade, a emergência de instituições, pois para a abordagem processual a sociedade está sempre 'se fazendo', mudando, ainda que de forma incremental. Não há, para ele, dicotomia entre Estado e sociedade; ambos estão implicados em uma configuração social de poder que é recriada e reformatada em contextos competitivos mutantes.

\section{TIPOSDE PARTIC IPANTES: ATO RES GOVERNAMENTAIS, SOCIAIS E DE MERCADO E SEUS REPRESENTANTES}

Em um nível de análise mais detalhado e próximo dos objetos empíricos examinados, na maior parte do tempo os atores estatais foram tratados como governamentais. $\mathrm{O}$ conceito de atores estatais abarca tanto indivíduos que ocupam cargos de direção em órgãos do Executivo ou em organizações governamentais como aqueles que estão vinculados a órgãos de outros poderes. Embora, dependendo do conceito de Estado adotado, a ação estatal possa ocorrer fora do Estado formalmente constituido (Gramsci, 2004; Bourdieu, 1994), os atores estatais enfocados nesta obra são estritamente governamentais. Eles são representantes da gestão em saúde de nível federal, estadual ou municipal ou de órgãos públicos, dos três poderes, que não atuam diretamente na área da saúde.

O conceito de atores societais também é muito amplo para expressar diferenças essenciais entre dois tipos de atores: os sociais e os de mercado. Enquanto os primeiros estão associados ao conceito de sociedade civil, os segundos estão relacionados com a noção de economia de mercado. Diversos autores têm enfatizado os limites teóricos do conceito de sociedade civil para análise das relações entre Estado e sociedade (Baker, 2000; Bonfim \& 
Fernandes, 2004; Edwards \& Foley, 1998; Lavalle, 2003; Pinto, 2004; Silva, 2004). Lavalle (2003), Silva (2004) e Pinto (2004) criticam tanto a positividade atribuída ao conceito de sociedade civil, vista como portadora de interesses gerais universais, quanto a negatividade conferida às instituições políticas, por agirem de acordo com interesses corporativos e particularistas.

Sem assumir a carga normativa aferida ao conceito, considera-se aqui que a sociedade civil e seus atores seriam diferentes do Estado e do mercado, e de seus atores. Os atores estatais e de mercado seriam compelidos a agir em ambientes regidos pelo poder e pelo dinheiro, enquanto o mesmo não aconteceria com os atores sociais. Segundo Cohen (2003: 427), os atores sociais não visam a tomar o poder do Estado ou organizar a produção, mas, sim, a "exercer influência por meio da participação em associações e movimentos democráticos". Atores de mercado buscam controlar e administrar a produção, maximizar seus lucros no ambiente de trocas mercantis. Os decisores econômicos, por mais que discutam problemas como os impactos sociais ou ambientais de ações empresariais ou decisões estatais, não podem se furtar dos imperativos da produtividade e do lucro. $O$ sentido principal de suas ações politicas seria guiado por tais imperativos.

Tendo em vista os casos empíricos examinados e a literatura sobre grupos sociais mais influentes na área da saúde (Carapinheiro, 1998; Freidson, 1998; Lee \& Mills, 1985; Marmor, 1983; Walt, 1994;), os atores sociais foram classificados nas seguintes categorias: profissionais e trabalhadores de saúde; trabalhadores, não especificamente da área da saúde; associações comunitárias, movimentos sociais e organizações não governamentais (ONGs); entidades étnicas, de gênero e de portadores de patologias ou deficiências; e igrejas. Levando em conta os mesmos critérios, os atores de mercado foram subdivididos em prestadores privados de serviços de saúde, envolvidos na provisão de serviços (diretamente ou na oferta de seguros de saúde) ou como empresários, com interesses não diretamente vinculados à área da saúde.

Os conselhos e parte dos mecanismos de participação encontrados nos hospitais não estavam abertos à participação direta de indivíduos, mas sim a representantes de organizações que puderam ser classificadas nas categorias aqui listadas. Alguns analistas têm questionado a legitimidade de representantes que integram fóruns participativos institucionalizados (Fiorina, 1999; Pinto, 2004; Skocpol, 1999). Na visão desses autores, somente 
teriam acesso à participação os grupos societais que dispõem de maiores recursos econômicos e de poder; os 'excluídos' continuariam à margem desses processos participativos. Mesmo reconhecendo que as críticas são procedentes, os textos reunidos neste livro partem do pressuposto de que a representação que ali se exerce é uma ação política 'substantiva'. A noção se baseia na idéia de agir por outro, não no "sentido meramente formal de que ela/e tenha sido autorizado ou vá ser considerado responsável, mas considerando a substância real por trás da formalidade: a atividade de representar" (Pitkin, 1969: 14).

Tal visão permite a distinção entre posição formal ou legal da pessoa e daqueles que ela realmente representa, em termos de ações. Assim, por exemplo, é possível dizer que um determinado individuo representa os interesses de portadores de patologias ou de profissionais e trabalhadores da saúde. Mais importante que a autorização formal ou que a responsabilização, ou que examinar se o representante simboliza ou se parece com o representado, é verificar se a substância de sua atividade é identificada com esses interesses (Pitkin, 1969). No mesmo sentido, baseada nos trabalhos de Pitkin (1969) e Manin (1997), Urbinati (2006: 191-192) argumenta que "a representação política é um processo circular (suscetível ao atrito) entre as instituições estatais e as práticas sociais".

No campo da saúde, a crítica à falta de legitimidade de representantes em fóruns participativos - apontados como mais educados e com níveis de escolaridade e socioeconômico superiores aos de seus representados - levou à busca por um modelo de representação que espelhasse, descrevesse os representados. Um exemplo clássico desse tipo de iniciativa ocorreu nos Estados Unidos, nas Agências do Sistema de Saúde (Health System Agencies - HSA). As HSA, com participação dominante de usuários de serviços, foram criadas em 1974. Sua composição deveria obrigatoriamente espelhar descritivamente todos os grupos sociais e demográficos da comunidade. Esse modo de seleção de representantes redundou em problemas. Primeiro, constatou-se que era impossivel 'espelhar' uma população inteira, pois a variedade potencial de grupos de interesses é infinita (Wainwright, 1992). Segundo, em vez de refletir os interesses e as opiniões de uma dada população, tais representantes refletiam apenas suas características demográficas (Marmor, 1983). Terceiro, nem todas as características podiam estar representadas. Sentimentos e opiniões discriminatórias de cunho racista ou sexista, embora 
presentes, não deveriam ser aceitos (Marmor, 1983). O quarto problema é que esse tipo de representação torna a consulta aos representados desnecessária, pois a ênfase é depositada na ampla representação, e não na responsabilidade do representante ante os representados (Marmor, 1983).

$\bigcirc$ desenho institucional de mecanismos participativos seria mais eficaz se fosse reduzida a preocupação com a semelhança demográfica da representação, que supostamente garantiria visão política similar. A atenção deveria ser concentrada na representação de interesses ou na capacidade de apresentação de idéias e valores. Assim, a "efetividade dos representantes é crucial para a representação substantiva. Um orador eloqüente ou um operador político habilidoso pode oferecer melhor representação substantiva que outro com um conhecimento igual dos interesses dos representados, mas desprovido das mesmas habilidades” (Marmor, 1983: 82).

Mesmo que os representantes tenham melhor condição social que a média dos representados, sua capacidade representativa, ou mesmo a sua liderança, é o que os legitima pela noção de 'bases' representadas. A representação substantiva introduz a noção de que as bases devem escolher seus representantes, os quais terão de ser responsáveis por seus atos políticos e poderão ser substituídos se não perseguirem apropriadamente os objetivos que os representados percebem como de seu interesse.

No caso dos mecanismos de participação em foco, a escolha pelas bases geralmente não ocorre. No entanto, as organizações que indicam os representantes, em geral, são presididas por diretorias compostas por membros eleitos. Os representantes nos conselhos, tanto os indivíduos quantos as entidades, são substituídos freqüentemente. Estudos têm mostrado, entretanto, que certos indivíduos permanecem durante muito tempo como conselheiros (Côrtes, 1995; Tatagiba, 2002). Mas sua permanência chama a atenção exatamente porque transgride as normas que regulam a composição dos fóruns, as quais apresentam dispositivos que prevêem a substituição de representantes e de entidades representadas. Saliente-se, porém, que não são as bases que os substituem, como no caso de membros dos parlamentos. A substituição fica a cargo ou da entidade representada, que indica outro membro para representá-la, ou do próprio fórum, que pode modificar sua composição.

Mesmo levando em conta essas peculiaridades, utiliza-se aqui o conceito de representação na acepção de 'representação substantiva', pois o que 
importa, ao se analisar a participação de representantes nos mecanismos analisados, é a substância real subjacente à formalidade: a atividade de representar. Assume-se, portanto, que, mesmo que de forma parcial, os representantes agem nesses fóruns e na arena decisória da saúde de acordo com as idéias dos representados.

\section{Redes de Poúticase Comunidades Poúticas}

Existem atores, no entanto, cuja natureza não permite a formalização da atividade de representação e cuja posição no contexto da política não pode ser determinada em relação ao Estado, ao mercado ou à sociedade civil. Segundo Heclo (1978), esse seria o caso das comunidades de políticas (policy communities) que agem em contextos de redes de políticas. As comunidades constituem-se a partir de suas relações com outros atores no interior de redes existentes em áreas específicas de políticas públicas. Elas se tornaram importantes na medida em que as decisões políticas no setor público dependem, cada vez mais, de um aparato estatal profissionalizado que formula políticas setoriais substantivas. Citando Larsons (1977), Dunleavy (1981: 7) usa o conceito de "corporativismo ideológico" para explicar o papel de comunidades profissionais em organizações estatais modernas. A característica central dessas comunidades seria a efetiva integração de diferentes organizações ou instituições em um nível substantivo de decisão política, por meio da aceitação ou dominância, através de setores e instituições, de uma visão de mundo.

O conceito de comunidade de política (Heclo, 1978) é uma tentativa de categorizar a crescente complexidade e especificidade das áreas de políticas públicas que demandam a expertise de especialistas (Marshall, 1988). O conceito de redes de políticas é um meio de designar a relação entre grupos de interesse, especialistas e o governo ou seções do governo. As redes envolvem uma grande variedade de atores movendo-se para dentro e para fora das arenas políticas, com visões diferentes sobre quais deveriam ser os resultados das políticas. Elas pressupõem a existência de uma grande variedade de centros de decisão política (Smith, 1991).

A noção de comunidade de política, em contraste, refere-se a um número limitado e relativamente estável de membros que dividem os mesmos valores e visão sobre quais deveriam ser os resultados da política setorial. As decisões são tomadas dentro dessas comunidades, em processos fechados 
para outras comunidades e para o público em geral (Rodes, 1986). Comunidades de políticas participam das redes de políticas, tentando afetar processos decisórios que se tornaram muito segmentados, na medida em que as políticas são elaboradas por uma miríade de organizações interconectadas e interpenetradas (Jordan \& Richardson, 1979). Essas comunidades têm substituído o centro que se desintegra - os congressos e a direção dos ministérios - como fonte substancial de decisões.

$\mathrm{Na}$ área da saúde, comunidades e redes de políticas incluem indivíduos de várias instituições, áreas de conhecimento ou profissões. Eles podem trabalhar na prestação de serviços, liderar organizações da sociedade civil, atuar como pesquisadores e acadêmicos ou como gestores. Redes de políticas são "formadas pela confluência e superposição conflituosa de comunidades de políticas existentes dentro e fora do Governo" (Walt, 1994: 110-111). As redes de política na área da saúde, em um dado período, são arenas formadas pelas relações complexas que se estabelecem entre companhias farmacêuticas, profissionais, prestadores privados de serviços hospitalares, associações de portadores de patologias, dentre outros grupos de interesse, e comunidades de políticas, que têm membros dentro e fora do governo.

As comunidades de políticas participam dessa arena em rede tentando influenciar a formulação de políticas e seus resultados. Podem existir diferenças dentro da comunidade, especialmente relacionadas a questões administrativas (Dunleavy, 1981), as quais tendem a se transformar em clivagens partidárias, ou entre facções de partidos. Esse processo é mais acentuado em sistemas políticos como o brasileiro, no qual vários partidos competem sem a clara predominância de nenhum. No entanto, a unidade da comunidade mantém-se enquanto houver consenso político e ideológico em torno de uma determinada visão sobre a explicação para os principais problemas da área em que atua e, principalmente, sobre um conjunto básico e essencial de propostas.

As noções de comunidade e rede de politica (Heclo, 1978; Jordan \& Richardson, 1979; Rodes, 1986) buscam entender como se processam as decisões nas diversas áreas de políticas públicas e nos centros decisórios gerais dos governos. Como afirmam True, Jones e Baumgartner, elas podem ser denominadas "como triângulos de ferro, nichos temáticos, subsistemas políticos, redes temáticas", mas "qualquer que seja a denominação adotada, ela se refere a uma comunidade de especialistas operando fora do processo político visível, em contextos nos quais a maior parte das questões de 
cada política setorial específica é tratada no interior de uma comunidade de experts" (True, Jones \& Baumgartner, 2007: 157, 158).

Na área da saúde no Brasil, desde 1970 podem ser identificadas duas comunidades de políticas exercendo forte influência sobre o processo de decisão política federal (Paim, 1989; Teixeira, 1989). Nos anos 70, a mais influente era formada por dirigentes públicos - do Instituto Nacional de Previdência Social (INPS), depois do Instituto Nacional de Assistência Médica da Previdência Social (Inamps) e do Ministério da Saúde - que tinham conexões com a indústria farmacêutica, com entidades de prestadores privados de serviços, empresas de medicina de grupo e organizações de profissionais de saúde, particularmente da área médica, por meio do Conselho Federal de Medicina, conselhos, associações e sindicatos médicos estaduais. Essa articulação política determinou a consolidação e a expansão de um modelo de organização de serviços de saúde cuja característica central era a provisão privada oferecida nos centros urbanos, financiada com recursos da previdência social, controlada por mecanismos frágeis de regulação.

Durante as décadas de 1980 e 1990, a predominância dessa comunidade de política foi desafiada por uma comunidade que propunha a reforma do modelo consolidado na década anterior. A última era formada por acadêmicos, pesquisadores, sindicatos de profissionais e trabalhadores de saúde e por lideranças de movimentos sociais e ficou conhecida como 'movimento sanitário'. Ela criticava a organização do sistema de saúde brasileiro então vigente, e suas propostas eram inspiradas nos princípios defendidos na Declaração dos Cuidados Primários de Saúde e nos modelos inglês e cubano de atenção à saúde. Sua crescente influência resultava, em parte, da democratização em curso no país. Ela pode ser vista também como expressão da complexificação da sociedade brasileira que favorecia a formação de atores coletivos - que podiam se manifestar cada vez mais livremente - pressionando o governo a atender às suas demandas. A crescente influência dessa comunidade sobre o governo federal está relacionada também à crise econômica profunda que o país enfrentava durante os anos 80 , que limitava drasticamente a capacidade de realizar gastos públicos, tornando bem-vindas políticas racionalizadoras, como as que os reformadores propunham.

Essa comunidade defendia a construção de um sistema de saúde único, que oferecesse acesso universal à atenção integral à saúde, organizado de forma descentralizada, hierarquizada, com participação de usuários, trabalhadores de saúde e prestadores de serviço. Como será visto nos capítulos 
que tratam do Conselho Nacional de Saúde, nos últimos anos alterou-se a configuração das relações sociais que constituíam a rede de política da área da saúde. O movimento sanitário, comunidade reformista formada no final da década de 1970, sofreu um processo de diferenciação interna - ao menos em parte, produzido por mudanças no modo como o Sistema Único de Saúde (SUS) passou a se organizar no país - que deu origem a duas novas comunidades.

Assim, os capítulos deste livro compartilham o referencial teóricoconceitual aqui apresentado. Ele é utilizado com inflexões diferentes conforme a natureza de cada caso examinado, na busca de ampliar a compreensão que temos sobre o papel que mecanismos participativos exercem na estrutura das relações sociais da área e nas instituições hospitalares estudadas. Assim todos os capítulos examinam os tipos de decisões tomadas e ações realizadas por esses mecanismos, para compreender como eles se relacionam com os diversos espaços de decisão política - sejam eles abertos, sejam fechados ao escrutínio público.

Mesmo considerando as especificidades de cada estudo, todos partem do pressuposto de que tais relações envolvem atores coletivos que, por vezes, atuam através dos limites entre Estado e sociedade, organizados em comunidades de politicas que agem em contextos de redes de políticas procurando ampliar sua influência na arena decisória da área. Por isso, buscam indicações da existência dessas comunidades e, quando as encontram, caracterizam a sua atuação no fórum examinado e na rede da política de saúde. As indicações mais expressivas da ação dessas comunidades foram encontradas na análise do Conselho Nacional de Saúde, apresentada no primeiro capítulo.

\section{REFERÊNCIAS}

AMENTA, E. State-centered and political institutional theory: retrospect and prospect. In: JANOSKI, T. et al. (Eds.) The Handbook of Political Sociology: States, civil societies and globalization. Cambridge: Cambridge University Press, 2005.

ARCHER, M. Human agency and social structure: a critique of Giddens. In: CLARK, J.; MODGIL, C. \& MODGIL, S. (Eds.) Anthony Giddens: consensus and controversy. Brighton: Falmer Press, 1990.

ARCHER, M. Realist Social Theory: the morphogenetic approach. Cambridge: Cambridge University Press, 1996.

ARNSTEIN, S. R. A ladder of citizen participation. Journal of American Institute Planners, 35(3): 216-224, 1969. 
BAKER, G. Civil Society and Republican Democracy. Paper for Political Studies Association. UK Annual Conference, Londres, 10-13 abr. 2000.

BERGH, G. B. D. The Structure of Development: an invitation to the sociology of Norbert Elias. The Hague: Institute of Social Studies, 1971. (ISS Occasional Paper, 13)

BONFIM, W. L. S. \& FERNANDES, A. S. A. Teorias democráticas contemporâneas e o caso brasileiro pós-Constituição de 1988. In: ENCONTRO ANUAL DA ANPOCS, 28, ST23, 2004, Caxambu. Anais... Caxambu, Minas Gerais: Anpocs, 2004.

BOURDIEU, P. Raisons Pratiques: sur la théorie de l'action. Paris: Seuil, 1994.

BRANDTSTÄDTER, S. Elias in China 'civilising process', kinship and customary law in the Chinese countryside. Halle, Saale: Max Planck Institute for Social Anthropology, 2000. (Working Paper, 6)

BRASIL. Congresso Nacional. Lei n. 8.142, de 28 de dezembro de 1990. Dispõe sobre a participação da comunidade na gestão do Sistema Único de Saúde (SUS) e sobre as transferências intergovernamentais de recursos financeiros na área de saúde e dá outras providências.

CARAPINHEIRO, G. Saberes e Poderes no Hospital: uma sociologia dos serviços hospitalares. Porto: Afrontamento, 1998.

COHEN, J. L. Sociedade civil e globalização: repensando categorias. Dados - Revista de Ciências Sociais, 46(3): 419-459, 2003.

CÔRTES, S. M. V. User Participation and Reform of the Brazilian Health System: the case of Porto Alegre, 1995. Tese de Doutorado, Londres: Department of Social Policy and Administration, London School of Economics and Political Science.

DAGNINO, E. Sociedade civil e espaços públicos no Brasil. In: DAGNINO, E. (Org.) Sociedade Civil e Espaços Públicos no Brasil. São Paulo: Paz e Terra, 2002.

DAGNINO, E.; OlVERA, A. J. \& PANFICHI, A. (Orgs.) A Disputa pela Construção Democrática na América Latina. São Paulo: Paz e Terra, 2006.

DUNLEAVY, P. Professions and policy change: notes towards a model of ideological corporatism. Public Administration Bulletin, 36: 3-16, 1981.

EDWARDS, B. \& FOLEY, M. W. Civil society and social capital beyond Putnam. American Behavioral Scientist, 42(1): 124-139, 1998.

ELIAS, N. O Processo Civilizador. Rio de Janeiro: Jorge Zahar, 1993.

EVANS, P. Transnational linkages and State capacities: an analysis of developing and industrial societies in the Post-World War II period. In: EVANS, P.; RUESCHEMEYER, D. \& SKOCPOL, T. (Eds.) Bringing the State Back In. Cambridge, Nova York: Cambridge University Press, 1985.

FIORINA, M. P. A dark side of civic engagement. In: SKOCPOL, T. \& FIORINA, M. P. (Eds.) Civic Engagement in American Democracy. Washington: Brookings, Sage, 1999.

FREIDSON, E. O Renascimento do Profissionalismo: teoria, profecia e política. São Paulo: EdUSP, 1998.

GIDDENS, A. A Constituição da Sociedade. São Paulo: Martins Fontes, 1989. 
GOODWIN, J. No Other Way Out: States and revolutionary movements, 1945-1991. Cambridge, Nova York: Cambridge University Press, 2001.

GRAMSCI, A. Cadernos do Cárcere. 3. ed. Rio de Janeiro: Civilização Brasileira, 2004. HALL, P. A. \& TAYLOR, R. C. R. As três versões do neo-institucionalismo. Lua Nova, 58: 193-223, 2003.

HAM, C. J. Community health council participation in NHS planning system. Social Policy and Administration, 14(3): 221-231, 1980.

HAY, C. Restating Social and Political Change. Buckingham: Open University, 1996.

HAY, C. Political Analysis: an introduction. Basingstoke: Palgrave, 2002.

HECLO, H. Issue network and the executive establishment. In: KING, A. (Ed.) The New American Political System. Washington, D.C.: American Enterprise Institute for Public Policy Research, 1978.

HOGGETT, P. Agency, rationality and social policy. Journal of Social Policy, 30: 37-56, 2001.

JESSOP, B. State Theory: putting the capitalist state in its place. Cambridge: Polity Press, 1990.

JESSOP, B. Bringing the State back in (yet again): reviews, revisions, rejections, and redirections. International Review of Sociology, 11(2): 149-153, 2001.

JORDAN, G. \& RICHARDSON, J. J. Governing Under Pressure. Oxford: Martin Robertson, 1979.

LABRA, M. E. \& FIGUEIREDO, J. S. A. Associativismo, participação e cultura cívica: o potencial dos conselhos de saúde. Ciência Ė Saúde Coletiva, 7(3): 537-547, 2002.

LARSONS, M. S. The Rise of Professionalism. Berkeley: University of California Press, 1977.

LAVALLE, A. G. Sem pena nem glória: o debate sobre a sociedade civil nos anos 1990. Novos Estudos Cebrap, 66: 91-109, 2003.

LEE, K. \& MILLS, A. Policy-Making and Planning in the Health Sector. Londres: Croom Helm, 1985.

LOWNDES, V. Institutionalism. In: MARSH, D. \& STROKER, G. (Eds.) Theory and Methods in Political Science. 2. ed. Basingstoke: Palgrave MacMillan, 2002.

MANIN, B. The Principles of Representative Government. Cambridge: Cambridge University Press, 1997.

MARMOR, T. R. Political Analysis and American Medical Care. Nova York: Cambridge University Press, 1983.

MARSHALL, N. The failure of the academic lobby: from policy community to bureaucratic management. Politics, 23: 67-79, nov. 1988.

MCANNULA, S. Structure and agency. In: MARSH, D. \& STROKER, G. (Eds.) Theory and Method in Political Science. Nova York: Palgrave, 2002.

PAIM, J. N. S. As politicas de saúde e a conjuntura atual. Espaço para a Saúde, 1: 18-24, mar. 1989. 
PAUL, S. Community Participation in Development Projects: the World Bank experiences. Washington: The World Bank, 1987.

PETERS, B. G.; PIERRE, J. \& KING, D. S. The politics of path dependency: political conflict in historical institutionalism. The Journal of Politics, 67(4): 1.275-1.300, 2005. PIERSON, P. Dismantling the Welfare State? Reagan, Thatcher, and the politics of retrenchment. Cambridge: Cambridge University Press, 1994.

PINTO, C. R. J. Espaços deliberativos e a questão da representação. Revista Brasileira de Ciências Sociais, 19: 97-116, 2004.

PITKIN, H. F. Representation. Nova York: Atherton Press, 1969.

RAICHELIS, R. Esfera Pública e Conselhos de Assistência Social: caminhos da construção democrática. São Paulo: Cortez, 2000.

RODES, R. A. W. The National World of Local Government. Oxford: Allen and Unwin, 1986.

SABATIER, P. A. \& JENKINS-SMITH, H. Policy Change and Learning: an advocacy coalition approach. Boulder, CO: Westview Press, 1993.

SCHMIDT, V. A. Theorizing democracy in Europe: the impact of the EU on national and sectoral policy-making processes. In: EUROPEAN UNION STUDIES ASSOCIATION (EUSA). Biennial Conference, 9. Austin, Texas, 31 mar.-2 abr. 2005. SILVA, I. F. \& LABRA, M. E. As instâncias colegiadas do SUS no estado do Rio de Janeiro e o processo decisório. Cadernos de Saúde Pública, 17(1): 161-170, 2001.

SILVA, M. K. Entre a norma e o factual: questões para uma análise sociológica dos processos de participação social na gestão pública. Política e Sociedade, 1(1): 185-200, 2004.

SILVA, M. K. Sociedade civil e construção democrática: do maniqueísmo essencialista à abordagem relacional. Sociologias, 8: 156-179, 2006.

SKOCPOL, T. Bringing the State back in: strategies of analysis in current research. In: EVANS, P.; RUESCHEMEYER, D. \& SKOCPOL, T. (Eds.) Bringing the State Back In. Cambridge, Nova York: Cambridge University Press, 1985.

SKOCPOL, T. Protecting Soldiers and Mothers: the political origins of social policy in the United States. Cambridge: Belknap Press of Harvard, 1992.

SKOCPOL, T. Associations without members: the recent transformation of American civic life. In: SKOCPOL, T. \& FIORINA, M. P. (Eds.) Civic Engagement in American Democracy. Washington: Brookings, Sage, 1999.

SMITH, M. M. From policy community to issue network: salmonella in eggs and the new politics of food. Public Administration, 69 (Summer): 235-255, 1991.

STEINMO, S. Structuring Politics: historical institutionalism in comparative analysis. Cambridge, Nova York: Cambridge University Press, 1993.

TATAGIBA, L. Os conselhos gestores e a democratização das politicas públicas no Brasil. In: DAGNINO, E. (Org.) Sociedade Civil e Espaços Públicos no Brasil. São Paulo: Paz e Terra, 2002. 
TEIXEIRA, S. M. F. Política de saúde na transição conservadora. Saúde em Debate, 26: 42-53, set. 1989.

TRUE, J. L.; JONES, B. D. \& BAUMGARTNER, F. R. Punctuated-equilibrium theory: explaining stability and change in public policy making. In: SABATIER, P. A. (Ed.) Theories of the Policy Process. Boulder: Westview Press, 2007.

URBINATI, N. O que torna a representação democrática? Lua Nova, 67: 191-228, 2006.

VALLA, V. V. Comentários a 'Conselhos Municipais de Saúde: a possibilidade dos usuários participarem e os determinantes da participação’. Ciência Ė Saúde Coletiva, 3(1): 31-32, 1998.

WAINWRIGHT, D. Building a Dialogue: community participation in health sector decisionmaking. Bexley: Bexley Health Authority, Department of Public Health, 1992. (Mimeo.) WALT, G. Health Policy: an introduction to process and power. Londres: Zed Books, 1994. WEIR, M.; ORLOFF, S. \& SKOCPOL, T. Introduction: understanding American social politics. In: WEIR, M.; ORLOFF, S. \& SKOCPOL, T. (Eds.) The Politics of Social Policy in the United States. Princeton: Princeton University Press, 1988. 



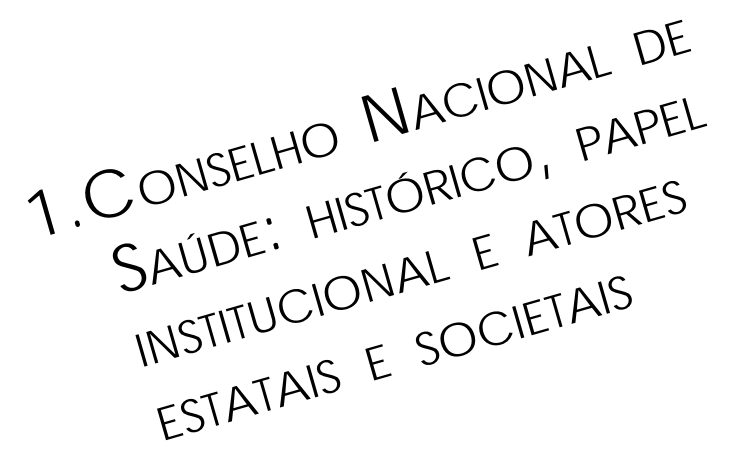

\author{
Soraya Vargas Côrtes \\ Marcelo Kunrath Silva \\ Janete Cardoso Réos \\ Márcio Barcelos
}

Este capitulo tem como objetivo fazer uma caracterização do Conselho Nacional de Saúde sem perder de vista as duas indagações básicas que orientaram as pesquisas sobre conselhos que integram este livro: como os diversos atores participam nas atividades do Conselho e qual o papel do fórum na arena decisória da área. Para isso, analisam-se os textos legais para identificar mudanças em suas funções e em sua composição desde a sua criação, em 1937, até a alteração regimental ocorrida em 2006. As variações na composição do Conselho verificadas ao longo do tempo, especialmente no que tange às proporções entre atores estatais, de mercado e sociais, são relacionadas a transformações no sistema de saúde brasileiro e, particularmente, no desenho institucional da área. Desse modo, é possível compreender, ao menos em parte, as mutações no papel que ele desempenhou na arena decisória da área ao longo do período.

Em suas origens, na década de 1930, o Conselho era um órgão consultivo do então Ministério da Educação e Saúde Pública, formado por especialistas em saúde pública. Quando ele foi 'recriado', em 1990, seu papel institucional ficou indefinido. Até meados da década de 1990, foi o palco central dos embates sobre a reforma do sistema brasileiro de saúde em curso. O Conselho anunciava-se como um canal para a representação de interesses de atores societais diante do Estado e como um importante espaço político de mediação de interesses e tomada de decisões na área da 
saúde. O redesenho institucional do sistema, com o fortalecimento dos níveis subnacionais de governo - e, portanto, de atores governamentais provenientes de estados e municípios -, e a criação de instâncias federativas de gestão compartilhada - as comissões intergestores - não favoreceram o Conselho a ocupar lugar central na arena decisória da área. Tais definições sobre o desenho institucional que o Sistema Único de Saúde (SUS) passou a ter foram em grande parte provocadas pela atuação da comunidade de política reformista, o 'movimento sanitário', ao longo dos anos 90. Entretanto, as escolhas estratégicas dos atores que lideravam a dinâmica de funcionamento do Conselho de certa forma consolidaram um lugar relativamente secundário do fórum na arena decisória da área.

Para a elaboração deste capítulo, foram analisadas principalmente as leis e portarias ministeriais pertinentes e as resoluções do próprio Conselho. Para complementar a análise, foram examinadas atas de 11 reuniões plenárias do fórum realizadas em 2005, ${ }^{1}$ entrevistas com conselheiros, ${ }^{2}$ informações disponíveis nos sites do Conselho e do Ministério da Saúde, documentos obtidos no Conselho e diários de campo de observações de reuniões plenárias. ${ }^{3}$

O capítulo, inicialmente, apresenta um histórico do Conselho até a sua reformulação em 1990, no contexto da estruturação do SUS, para em seguida examinar os 16 anos seguintes.

\footnotetext{
${ }^{1}$ Apesar de terem ocorrido 12 reuniões plenárias do Conselho Nacional de Saúde (CNS) em 2005, foram analisadas somente 11 atas, pois a ata da 153a reunião - de 12, 13 e 14 de abril de 2005 - estava disponivel somente no formato de resumo executivo. Examinaram-se as seguintes atas: $150^{a}$, de 11,12 e $13 / 1 / 2005 ; 151^{\text {a }}$, de 15 , 16 e $17 / 2 / 2005 ; 152^{2}$, de 8,9 e $10 / 3 / 2005 ; 154^{\text {a }}$, de 4 e $5 / 5 / 2005 ; 155^{a}$, de 8 e $9 / 6 / 2005 ; 156^{a}$, de 13 e $14 / 7 / 2005$; $157^{\text {a }}$, de 10 e $11 / 8 / 2005 ; 158^{\text {a }}$, de 14 e 15/9/2005; 159a de 18,19 e 20/10/2005; 160a de 8,9 e 10/11/2005; e $161^{\text {a }}$, de 14 e 15/12/2005. As atas encontram-se disponiveis no seguinte endereço eletrônico: <http:// conselho.saude.gov.br/atas/atas_08.htm>.

${ }^{2}$ Foram realizadas 23 entrevistas de abril a setembro de 2006. Entrevistaram-se: 1) 13 conselheiros e ex-conselheiros que representavam organizações da sociedade civil - um de organização religiosa; dois de entidades de trabalhadores, não especificamente da área da saúde; quatro de entidades de profissionais e trabalhadores de saúde; seis de entidades étnicas, de gênero e de portadores de patologias ou deficiências; 2) dois conselheiros e ex-conselheiros que representavam entidades de mercado - os dois de entidades nacionais de prestadores de serviços de saúde; e 3) oito conselheiros e ex-conselheiros que representavam órgãos governamentais - três de instituições não vinculadas à área da saúde e cinco de gestores de saúde (dois da esfera federal, um da estadual e dois da municipal).

${ }^{3}$ Foram realizadas quatro observaçoes às seguintes reuniões plenárias do Conselho: 159a reunião, em 18, 19 e 20/10/2005; 160ª reunião, em 8, 9 e 10/11/2005; 161 ra reunião, em 14 e 15/12/2005; $164^{\text {a }}$ reunião, em 4, 5 e 6/4/2006.
} 


\section{Histórico do ConselHo Nacional de Saúde}

O Conselho Nacional de Saúde foi criado em 1937, quando houve uma reorganização administrativa do então Ministério da Educação e da Saúde Pública. ${ }^{4}$ Constituía-se como 'órgão de cooperação’ cuja função precípua era assistir o ministro da Saúde (Brasil, 1937, art. 67). Em 1953, quando o Ministério da Saúde foi criado, com a separação das áreas de educação e saúde em dois ministérios, confirmou-se a permanência do Conselho no organograma do novo ministério (Brasil, 1953, art. 4\%). Ele permanecia com a "finalidade de assistir o Ministro" da Saúde "na determinação das bases gerais dos programas de proteção à saúde" (Brasil, 1954, art. 1\%). Eram 17 os membros do Conselho. Desses, 14 eram indicados pelo ministro e designados pelo presidente da República, oito deles "dentre pessoas de notória capacidade em assuntos relativos à saúde” e seis escolhidos dentre os titulares dos principais cargos de chefia do ministério (Brasil, 1954, art. ${ }^{\circ}$ ). Eram membros natos: o diretor-geral do Departamento Nacional de Saúde, o diretor-geral do Departamento Nacional da Criança e o ministro da Saúde, que presidia o Conselho.

Ainda na mesma década, em 1959, houve alteração na composição do fórum. O número de conselheiros passou para 24. Eram, então, oito pessoas de notório saber na área, seis titulares de cargos proeminentes no ministério e dez membros natos: o ministro da Saúde, que presidia o Conselho; o diretor-geral do Departamento Nacional de Saúde; o diretor-geral do Departamento Nacional de Endemias Rurais; o diretor-geral do Departamento Nacional da Criança; o diretor do Instituto Oswaldo Cruz; o presidente da Academia Nacional de Medicina; o presidente da Associação Médica Brasileira; o diretor-geral de Saúde do Exército; o diretor-geral de Saúde da Marinha; e o diretor-geral de Saúde da Aeronáutica. Os dez membros natos, bem como os seis servidores do Ministério da Saúde eram médicos (Brasil, 1959, art. 20).

$\mathrm{Na}$ década seguinte, houve novas modificações na composição do Conselho, embora sua função permanecesse a de 'assistir' o ministro da Saúde. A partir de 1960, ex-ministros da Saúde passaram também a ser membros natos, e o chefe de gabinete do Ministério da Saúde tornou-se o secretário-

\footnotetext{
${ }^{4}$ A lei n. 378 (Brasil, 1937) determinava, em seu artigo 67, que, "além do Conselho Nacional de Educação, assistirá o Ministério, o Conselho Nacional de Saúde”.
} 
geral do fórum, cargo criado então (Brasil, 1960, art. 2 e 3o). Em 1962, o Conselho passou a ter 26 membros (Brasil, 1962, art. $2^{\circ}$ e $3^{\circ}$ ). Os membros natos eram 14: o ministro da Saúde, que presidia o Conselho; os diretores-gerais do Departamento Nacional de Saúde, Departamento Nacional de Endemias Rurais, Departamento Nacional da Criança (três); o diretor do Instituto Oswaldo Cruz; o diretor da Escola Nacional de Saúde Pública; o superintendente da Fundação Serviço Especial de Saúde Pública; os diretores-gerais de Saúde do Exército, da Marinha e da Aeronáutica (três); o titular da Diretoria do Ensino Superior, do Ministério da Educação e Cultura; o diretor-geral do Departamento Nacional de Obras de Saneamento, do Ministério da Viação e Obras Públicas; o diretor da Divisão de Defesa Sanitária Animal, do Ministério da Agricultura; e o presidente do Conselho de Medicina da Previdência Social do Ministério do Trabalho. Eram conselheiros também quatro representantes de associações técnicocientíficas: os presidentes da Academia Nacional de Medicina, da Associação Médica Brasileira, da Sociedade Brasileira de Higiene e da Seção Brasileira da Associação Interamericana de Engenharia Sanitária. Havia ainda oito conselheiros indicados pelo ministro e designados pelo presidente da República "dentre pessoas de notória capacidade em assuntos relativos à saúde” (Brasil, 1962, art. 2º).

A composição do Conselho em 1962 mostra que suas atividades tornaram-se mais complexas e que a concepção de saúde dos dirigentes do Ministério da Saúde se ampliara. A criação do cargo de secretário-geral indica que atividades executivas de preparação e acompanhamento das atividades do fórum precisavam ser desempenhadas fora do horário exclusivo das reuniões. A inclusão de conselheiros que não tratavam de assuntos exclusivamente médicos sugere ainda que os gestores de então concebiam os problemas de saúde como também decorrentes das condições de saneamento, do modo como eram produzidos e distribuídos os alimentos e da maneira como eram formados os profissionais de saúde.

As mudanças na composição do Conselho ocorridas após o golpe militar de 1964 indicam, em contraste, que houve uma reversão a uma concepção mais restrita de saúde e de como lidar com os problemas sanitários. Alterações na legislação realizadas em 1964 e 1965, além de confirmarem a função consultiva do fórum, reduziram o número de membros para 14 conselheiros (Brasil, 1964, art. 1º e 30; Brasil, 1965, art. 1): o ministro, que o presidia; quatro membros natos, dirigentes de órgãos do Ministério 
da Saúde; quatro pessoas de notório saber em saúde; e representantes da Academia Nacional de Medicina, Sociedade Brasileira de Higiene, Associação Médica Brasileira, Academia Brasileira de Medicina Militar e Estado Maior das Forças Armadas. Outras entidades passaram a ser colaboradoras. O Conselho tornara-se menor, reconstituíra-se a predominância da categoria médica - provavelmente devido a uma concepção de saúde que acentuava a necessidade de intervenções médicas - e fortalecera-se a presença militar, em consonância com o que ocorria em diversas esferas da vida pública do país.

Em 1970, houve nova alteração na composição do Conselho, a qual, embora deixasse suas funções inalteradas (Brasil, 1970, art. 1), expressava as mudanças ocorridas no modelo de atenção à saúde durante a década de 1970, em pleno regime militar. O Conselho foi ampliado de 14 para 16 membros: o ministro da Saúde permaneceu na presidência; ambos os membros natos e as pessoas de notório saber passaram a ser cinco, em vez de quatro como na composição anterior; permaneceram os representantes da Academia Nacional de Medicina, da Academia Brasileira de Medicina Militar e do Estado Maior das Forças Armadas, enquanto aqueles que representavam a Sociedade Brasileira de Higiene e a Associação Médica Brasileira foram substituidos por conselheiros provenientes da Academia Nacional de Farmácia e da Academia Brasileira de Administração Hospitalar. Foram mantidos os dois membros das Forças Armadas, mas reduziu-se a representação direta da categoria médica e extinguiu-se a participação da Sociedade Brasileira de Higiene, ao mesmo tempo que se acresceram representantes das áreas de farmácia e de administração hospitalar. Embora as razões da alteração possam ser investigadas em estudos futuros, é possível relacionar a inclusão do representante da área farmacêutica com a intenção do regime de fomentar a indústria de medicamentos, que levaria à criação da Central de Medicamentos (Ceme), em 1971 (Brasil, 1971). A inclusão dos administradores hospitalares, por sua vez, estaria relacionada à política de incentivos diretos - financiamentos e compra de serviços - e indiretos - incentivos fiscais - ao setor privado hospitalar, que viriam a ser pilares da política de saúde promovida pelos governos militares.

A política de saúde dos governos militares incidia sobre um sistema dividido em dois subsetores: o de saúde pública e o previdenciário. $\bigcirc$ último detinha a maior parte dos recursos financeiros e, durante a década de 1970, com a contratação de prestadores de serviços hospitalares e de apoio diagnóstico e terapêutico, passou a ser responsável pelo financiamento da 
maior parte dos serviços de saúde ambulatoriais e hospitalares oferecidos à população brasileira. No final da década de 1970, a crise econômica e os custos crescentes da provisão de atendimento à saúde fortaleceram a idéia, entre gestores da área da saúde e fora dela, de que seria necessário reorganizar o sistema, integrando os dois subsetores e descentralizando o financiamento, o processo decisório e a provisão de serviços, do nível federal para os níveis subnacionais de governo.

Uma iniciativa do governo federal visando à integração dos subsetores foi a criação do Sistema Nacional de Saúde, em 1975 (Brasil, 1975). Em 1976, no âmbito do esforço de implementar o novo sistema, o Conselho foi novamente modificado (Brasil, 1976). Como "órgão colegiado integrante da estrutura básica do Ministério da Saúde” (Brasil, 1977, art. 1), suas competências praticamente não foram alteradas. Entretanto, sua composição e forma de funcionamento modificaram-se significativamente (Brasil, 1977, 1978). Embora o Ministério da Saúde continuasse predominante, com o ministro da Saúde mantendo a prerrogativa de presidir o fórum, representantes de outros ministérios passaram a integrá-lo. A nova composição incluía 23 conselheiros (Brasil, 1977, art. 2º, 3º 4º): sete eram membros natos, o ministro da Saúde e os presidentes das recém-criadas seis Câmaras Técnicas do Conselho; cinco eram representantes dos ministérios da Educação e Cultura, Interior, Previdência e Assistência Social, Agricultura e Trabalho; seis eram designados pelo ministro da Saúde, dentre instituições relacionadas com as áreas da saúde e de segurança nacional; e cinco eram escolhidos dentre técnicos de notória capacidade e experiência na área da saúde (Brasil, 1977, art. 4\%). A estrutura de apoio tornou-se mais complexa, passando a ser composta por: Secretaria Executiva; Setor de Apoio Administrativo; Setor de Documentação; Setor Financeiro e seis Câmaras Técnicas - Entorpecentes e Tóxicos, Hemoterapia, Alimentos, Saneantes Domissanitários, Cosméticos e Medicamentos (Brasil, 1977, art. 20). Observe-se que a estrutura de apoio administrativo formada nessa reorganização do Conselho assemelha-se à que existe atualmente, com as Câmaras Técnicas com funções semelhantes às atuais Comissões Permanentes e a coordenação geral da Secretaria Executiva.

Embora a criação de um Sistema Nacional de Saúde integrado não tenha tido sucesso (Oliveira \& Teixeira, 1986), a iniciativa antecipava o processo de reforma que ocorreria durante os anos 80 . O clima de democratização política e as recomendações das agências internacionais - 
marcadamente o Fundo das Nações Unidas para a Infância (Unicef), a Organização Mundial da Saúde (OMS) e o Banco Mundial - favoreceram o estabelecimento dos marcos legais e a formulação e implementação de políticas que visavam, principalmente, à integração e à descentralização do sistema público de saúde brasileiro e estimulavam a participação de novos atores no processo de decisão política da área.

Para liberalizar o ambiente político, uma vez que a crise econômica desde a segunda metade da década de 1970 havia reduzido a legitimidade do governo militar, o regime tornou-se menos opressivo e promoveu a criação de novos canais de representação política da sociedade civil. $\mathrm{O}$ governo procurava legitimar o regime autoritário e ampliar sua base social de sustentação por meio da implementação de políticas de redução da pobreza e expansão da cobertura previdenciária. Simultaneamente, no final da década, as relações entre os interesses das corporações econômicas e a tecnocracia estatal (Cardoso, 1975) passaram a ser criticadas até mesmo por setores da burguesia, insatisfeitos com a desaceleração do crescimento econômico. Foram gradualmente sendo restauradas ou criadas formas democráticas de representação e expressão política, tais como eleições para cargos executivos e liberdade de imprensa, de associação e de organização de partidos políticos. No início da década de 1980, projetos e programas governamentais constituíram comissões e comitês nos quais deveria haver representação da sociedade civil. Uma das características marcantes da reforma do sistema brasileiro de saúde, durante os anos 80 , foi a criação de mecanismos participatórios.

\section{A Reforma do Sistema Brasileiro de Saúde e o 'Novo' Conserho Nacional de Saúde}

Dois programas federais e a $8^{a}$ Conferência Nacional de Saúde, na década de 1980, e as provisões legais e administrativas, do início dos anos 90, podem ser considerados como as fundações sobre as quais o SUS foi erigido. Os programas foram as Ações Integradas de Saúde (AIS) e os Sistemas Unificados e Descentralizados de Saúde (Suds). A Conferência foi a primeira a contar com ampla participação de representantes da sociedade civil, enquanto as provisões legais e administrativas foram a Constituição Federal, as leis complementares n. 8.080/90 e 8.142/90 (Brasil, 1990a, 1990b) e as normas operacionais básicas do Ministério da Saúde. 
O Programa das AIS, de 1984, fazia parte da estratégia do regime militar de reduzir os gastos da previdência social com saúde, que vinham crescendo desde os anos 70. Esse programa estabelecia a transferência de recursos financeiros da previdência para o Ministério da Saúde e para estados e municípios. O objetivo principal era melhorar os serviços oferecidos nos três níveis da administração pública, para conter a demanda crescente por cuidados especializados e hospitalares, financiados pela previdência. Para facilitar a integração das ações dos provedores públicos, o Programa criou comissões interinstitucionais nos níveis federal, estadual, regional, municipal e local, que contavam com a participação da comunidade.

A partir de 1985, quando o primeiro governo civil assumiu a Presidência da República, o Programa passou a ser uma das principais políticas da área da saúde. A contínua transferência de recursos para municípios e a possibilidade de representantes de organizações da sociedade civil participarem na decisão sobre sua alocação favoreceram o fortalecimento das comissões municipais, especialmente nas cidades onde os movimentos social e sindical eram mais organizados. Gradualmente, entidades da sociedade civil, tais como associações comunitárias, clubes de mães e sindicatos, anteriormente excluídos do processo de decisão política da área, passaram a ver no empoderamento desses fóruns uma oportunidade para influenciar a tomada de decisões (Heimann et al., 1992).

O Suds foi criado, em 1987, por iniciativa dos dirigentes da área da saúde do governo federal que defendiam a reforma do sistema. A principal estratégia desse programa foi universalizar o acesso aos serviços de saúde previdenciários, ao mesmo tempo que racionalizava custos e o uso de recursos, unificando a gestão dos serviços de saúde pública e previdenciários nos níveis estadual e municipal da administração pública. A descentralização que promovia dava-se por meio da transferência de recursos financeiros, unidades, hospitais e pessoal da previdência social para estados, em um primeiro estágio, e para os municípios, em estágios subseqüentes. O Programa integrava os subsetores de saúde pública e previdenciários de atenção à saúde, virtualmente extinguindo o envolvimento direto da previdência social na provisão e compra de serviços.

O movimento sanitário, congregado em torno do Centro Brasileiro de Estudos de Saúde (Cebes) ${ }^{5}$ e da Associação Brasileira de Pós-Graduação em

\footnotetext{
${ }^{5}$ Para mais informações, consultar: 〈www.cebes.org.br>.
} 
Saúde Coletiva (Abrasco), ${ }^{6}$ considerava como questão de princípio que a sociedade civil tivesse controle sobre o sistema de saúde. Ao mesmo tempo, seus principais líderes tinham clareza sobre a necessidade de ampliação da base social de apoio à proposta reformista, o que poderia ocorrer com a mobilização de atores sociais a ser realizada nesses fóruns. O Suds, idealizado por reformistas que se encontravam em cargos de direção nos ministérios da Saúde e da Previdência e Assistência Social, abriu as comissões em todos os níveis de gestão à participação de representantes da sociedade civil.

Um dos principais marcos da atuação do movimento sanitário foi a realização da 8a Conferência Nacional de Saúde em 1986 (Teixeira, 1989). A Conferência reuniu cerca de quatro mil pessoas, sendo que mil participaram como delegados representando instituições públicas e privadas da área da saúde, as principais universidades do país, as maiores centrais sindicais, uniões de estudantes, sindicatos de trabalhadores rurais e urbanos, associações de profissionais da área da saúde, associações comunitárias, partidos políticos e as principais igrejas cristãs (Côrtes, 1995).

Resultado da articulação entre atores societais e estatais coordenada pela comunidade de política reformista, o Relatório Final da Conferência continha os princípios normativos sobre a reforma do sistema de saúde por eles defendidos. Embora houvesse divergências - enquanto alguns participantes defendiam um sistema estatizado denominado 'tipo cubano', outros preconizavam um sistema misto público-privado, chamado então de 'tipo italiano-inglês' (V. N., entrevista, 1/9/2006) -, o texto aprovado ao final continha conceitos e princípios sobre os quais havia relativo consenso (Brasil, 1987a). Saúde foi conceituada de forma abrangente, como o resultado das condições de nutrição, moradia, educação, renda, ambiente, transporte, lazer, liberdade, acesso a terra e a serviços de saúde. Coerentemente, como saúde dependeria de ações políticas em diversas áreas, a Conferência propôs a criação de um orçamento social que financiaria a seguridade social a ser implantada. Embora a proposta de estatização imediata tenha sido recusada, houve consenso sobre a necessidade de fortalecer e expandir o setor público. Saúde foi considerada como um direito que o Estado teria a obrigação de garantir. Foi proposta a reformulação do sistema de saúde e a criação do SUS organizado conforme as seguintes diretrizes: descentralização e fortalecimento do papel dos municípios, integralidade da atenção,

\footnotetext{
${ }^{6}$ Para mais informações, consultar: <www.abrasco.org.br/index.php>.
} 
regionalização e hierarquização dos serviços, universalização da cobertura e equidade de acesso aos serviços e participação da população. A Conferência criou ainda a Comissão Nacional da Reforma Sanitária, que viria, em certa medida, a ser a precursora do 'novo' Conselho Nacional de Saúde (V. N., entrevista, 1/9/2006).

A Comissão foi instalada no segundo semestre de 1986 (Brasil, 1986a), com a finalidade de "analisar as dificuldades identificadas no funcionamento da rede nacional de serviços de saúde, sugerir opções para a nova estrutura organizacional do sistema” e apresentar suas conclusões em um prazo de 180 dias. Coordenada pelo secretário-geral do Ministério da Saúde, era integrada de forma paritária por representantes governamentais e societais (Quadro 1).

Em 1987, ${ }^{7}$ o Conselho foi reformulado tanto em suas funções como em sua composição. Pela primeira vez desde a criação, teve como função administrativa principal a de "deliberação coletiva de segundo grau" no âmbito do Ministério da Saúde (Brasil, 1987b, art. 1º). Ou seja, passou a ser um órgão ministerial de deliberação superior, o que indica que os idealizadores da mudança propunham um novo papel para o Conselho na área da saúde. $\mathrm{O}$ fórum era integrado por 14 conselheiros: o ministro da Saúde, que o presidia; três representantes de outros ministérios (do Trabalho, da Educação e da Previdência e Assistência Social); um representante da Secretaria de Planejamento da Presidência da República (Seplan); um representante do Conselho Nacional de Secretários de Saúde (Conass); um representante do Conselho Nacional de Defesa do Consumidor (CNDC); e sete personalidades de notória capacidade e comprovada experiência em assuntos de saúde, estas indicadas pelo ministro da Saúde (Brasil, 1987b, art. $\left.3^{\circ}\right) .{ }^{8}$ No entanto, mesmo com a diversificação de seus integrantes, o Conselho não participou ativamente do intenso debate sobre a reforma do

\footnotetext{
${ }^{7}$ Em 1986, foi criada uma comissão interministerial encarregada de propor a reformulação do Conselho Nacional de Saúde, integrada por representantes dos ministérios da Saúde, da Previdência e Assistência Social, da Educação e do Planejamento (Brasil, 1986b). Em janeiro de 1987, a Comissão concluiu seus trabalhos e entregou a proposta ao ministro da Saúde.

${ }^{8}$ Eram consideradas como "colaboradoras do Conselho Nacional de Saúde as seguintes instituições: Associação Médica Brasileira, Academia Nacional de Medicina, Academia Nacional de Medicina Militar, Associação Brasileira de Enfermagem, Associação Brasileira de Odontologia, Federação Brasileira de Nutrição, Sociedade Brasileira de Medicina Veterinária, Academia Nacional de Farmácia, Academia Brasileira de Ciências e Sociedade Brasileira para o Progresso da Ciência" (Brasil, 1987b, art. 3ㅇ $\S 1^{\circ}$ ).
} 


\section{Quadro 1 - Composição da Comissão Nacional da Reforma Sanitária - 1986}

\begin{tabular}{|c|c|c|}
\hline \multirow[t]{2}{*}{$\begin{array}{l}\text { Representantes } \\
\text { estatais }\end{array}$} & Governamentais & $\begin{array}{l}\text { 1. Ministério da Saúde (secretário e presidente } \\
\text { da Fundação Oswaldo Cruz } \\
\text { 2. Ministério da Previdência e Assistência } \\
\text { Social (secretário de Servicos Médicos e } \\
\text { presidente do Instituto Nacional de } \\
\text { Assistência Médica da Previdência Social } \\
\text { (Inamps) } \\
\text { 3. Ministério da Educação e Cultura } \\
\text { (secretário de Educacão Superior) } \\
\text { 4. Ministério do Trabalho } \\
\text { 5. Ministério do Desenvolvimento Urbano e } \\
\text { Meio Ambiente } \\
\text { 6. Ministério da Ciência e Tecnologia } \\
\text { 7. Secretaria de Planejamento da Presidência } \\
\text { da República } \\
\text { 8. Secretarias estaduais de Saúde (dois } \\
\text { representantes do Conselho Nacional de } \\
\text { Secretários de Saúde, sendo um o presidente } \\
\text { da Comissão) } \\
\text { 9. Secretarias municipais de Saúde }\end{array}$ \\
\hline & $\begin{array}{l}\text { Congresso } \\
\text { Nacional }\end{array}$ & 10. Senado Federal (Comissão de Saúde) \\
\hline \multirow[t]{5}{*}{$\begin{array}{l}\text { Representantes } \\
\text { societais }\end{array}$} & $\begin{array}{l}\text { Prestadores } \\
\text { privados de } \\
\text { serviços de } \\
\text { saúde }\end{array}$ & $\begin{array}{l}\text { 1. Confederação das Misericórdias do Brasil } \\
\text { (CMB) } \\
\text { 2. Federação Brasileira de Hospitais (FBH) }\end{array}$ \\
\hline & $\begin{array}{l}\text { Profissionais de } \\
\text { saúde }\end{array}$ & 3. Federação Nacional dos Médicos (FNM) \\
\hline & Empresários & $\begin{array}{l}\text { 4. Confederacãa Nacional da Indústria (CNI) } \\
\text { 5. Confederação Nacional do Comércio } \\
\text { (CNC) } \\
\text { 6. Confederação Nacional da Agricultura } \\
\text { (CNA) }\end{array}$ \\
\hline & Trabalhadores & $\begin{array}{l}\text { 7. Confederação Nacional dos Trabalhadores } \\
\text { na Agricultura (Contag) } \\
\text { 8. Central Geral dos Trabalhadores (CGT) } \\
\text { 9. Central Unica dos Trabalhadores (CUT) }\end{array}$ \\
\hline & $\begin{array}{l}\text { Associações } \\
\text { comunitárias }\end{array}$ & $\begin{array}{l}\text { 10. Conselho Nacional das Associações de } \\
\text { Moradores (Conam) }\end{array}$ \\
\hline
\end{tabular}

Fonte: Brasil, 1986a. 
sistema de saúde brasileiro. Até sua reformulação, em 1990, ele continuou atuando como um 'conselho de notáveis'.

O Conselho Nacional de Saúde existia desde o tempo de Getúlio Vargas e era um Conselho de honoráveis, um Conselho, na época, [da Reforma Sanitária] (...) dirigido por um ex-senador da República. (...) até fazia parte o Doutor Zerbini, faziam parte nomes, porque ele era um Conselho Consultivo de médicos honoráveis da Sociedade Médica Brasileira que o ministro, eventualmente, se utilizava para consultar sobre assuntos da área da saúde. (W. J., entrevista, 20/9/2006)

A participação da sociedade na definição do novo desenho institucional da área da saúde brasileira se deu em outros espaços (V. N., entrevista, 1\%/9/2006). Dentre eles, aparecia em destaque a Comissão Nacional de Reforma Sanitária como um dos principais fóruns de debates, no qual se demarcaram posições conflitantes, se construíram consensos e se produziram diretrizes para o novo sistema de saúde. "A Comissão Nacional [da Reforma Sanitária] já tem representação da população, dos trabalhadores da saúde, ela já é um (...) embrião da nova forma de composição do Conselho” (K. L., entrevista, 13/6/2006).

A proposta final dessa Comissão, o Relatório Final da $8^{a}$ Conferência e a própria implementação do programa Suds fixaram uma agenda de propostas a serem incluídas na Constituição Brasileira de 1988. O movimento sanitário, em aliança com o movimento sindical e popular, construíra articulações e consensos durante os trabalhos da Comissão Nacional de Reforma Sanitária e da $8^{a}$ Conferência Nacional de Saúde. Foram integrantes dessa comunidade de política que elaboraram e implementaram o programa Suds (Arouca, 1988). Essa articulação de forças políticas e sociais defendeu - e teve sucesso em estabelecer no texto constitucional - a criação de um Sistema Único de Saúde (SUS) que, em linhas gerais, adotava as diretrizes por ela defendidas. O SUS oferecia atenção integral à saúde; os serviços de saúde eram de acesso universal; o sistema tinha participação da comunidade (Brasil, 1988, art. 198) e era financiado com recursos da previdência social e dos orçamentos federal, estadual e municipal - provenientes de diversas fontes fiscais. A maior parte da provisão era oferecida e gerenciada pelos municípios, deixando para os estados e a União as tarefas de monitoramento e avaliação. $O$ sistema era único, desaparecendo a divisão entre subsetores de saúde pública e previdenciária, e tinha gestão descentralizada, com participação da comunidade. 
As leis complementares da área da saúde normatizaram a implementação desses princípios. A lei n. 8.142 (Brasil, 1990b), em dezembro de 1990, criou conselhos de saúde nos níveis municipal, estadual e federal. Os novos fóruns eram permanentes, deliberativos, responsáveis pela "formulação de estratégias e controle da execução da política de saúde na instância correspondente, inclusive nos aspectos econômicos e financeiros" (Brasil, 1990b, art. 1\%). Eram integrados por representantes do governo, de prestadores de serviços, de profissionais de saúde e de usuários de serviços de saúde. Nos três níveis, os representantes de usuários comporiam metade do conselho, enquanto os demais membros somados integrariam a outra metade.?

Quando o novo Conselho Nacional de Saúde foi criado, em agosto de 1990 (Brasil, 1990c), antes mesmo da promulgação da lei n. 8.142, o antigo praticamente não existia mais. $O$ Conselho continuou integrando a estrutura básica do Ministério da Saúde, mas passou a ter caráter deliberativo. ${ }^{10}$ Desde então não ocorreram alterações importantes ${ }^{11}$ nas disposições legais sobre suas competências. No entanto, a composição do plenário do Conselho sofreu alterações entre 1990 e 2006 (Quadros 2, 3 e 4).

\footnotetext{
9 "O Conselho de Saúde, em caráter permanente e deliberativo, órgão colegiado composto por representantes do Governo, prestadores de serviço, profissionais de saúde e usuários, atua na formulação de estratégias e no controle da execução da politica de saúde na instância correspondente, inclusive nos aspectos econômicos e financeiros, cujas decisões serão homologadas pelo chefe do poder legalmente constituido em cada esfera do Governo" (Brasil, 1990b, art. 1).

${ }^{10}$ Suas principais competências passaram a ser: "I - atuar na formulação da estratégia e no controle da execução da Politica Nacional de Saúde (...); II - estabelecer diretrizes a serem observadas na elaboração dos planos de saúde (...); III - elaborar cronograma de transferência de recursos financeiros aos Estados, Distrito Federal e Municipios (...); IV - aprovar os critérios e valores para remuneração de serviços e os parâmetros de cobertura assistencial; V - propor critérios para a definição de padrões e parâmetros assistenciais; VI - acompanhar e controlar a atuação do setor privado da área da saúde (...); VII - acompanhar o processo de desenvolvimento e incorporação cientifica e tecnológica na área de saúde (...); VIII - articular-se com o Ministério da Educação quanto à criação de novos cursos de ensino superior na área de saúde (...)” (Brasil, 1990c, art. 1\%).

${ }^{11} \mathrm{O}$ decreto n. 5.839/06 (Brasil, 2006a), que viria a reformular a composição e a dinâmica de funcionamento do fórum de maneira mais profunda, manteve intocadas as competências do Conselho que foram estabelecidas pelo decreto n. 99.438/90 (Brasil, 1990c).
} 


\section{Quadro 2 - Composição do Conselho Nacional de Saúde por representan- tes estatais e societais - 1990-1992}

\begin{tabular}{|c|c|c|}
\hline \multirow{3}{*}{ 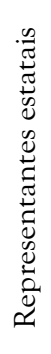 } & \multirow[t]{2}{*}{ Governamentais } & $\begin{array}{l}\text { - Ministério da Educação } \\
\text { - Ministério da Economia, Fazenda e Planejamento } \\
\text { - Ministério da Ação Social } \\
\text { - Ministério da Saúde (dois representantes, sendo um o ministro, presidente do Conselho) }\end{array}$ \\
\hline & & $\begin{array}{l}\text { - Ministério do Trabalho e da }\left\{\begin{array}{l}\text { Modificacão de } 1992 \\
\text { Previdência Social }\end{array}\right. \\
\text { - Ministério do Trabalho e da Administração } \\
\text { - Conselho Nacional de Secretários de Saúde (Conass) } \\
\text { - Conselho Nacional de Secretários Municipais de Saúde (Conasems) }\end{array}$ \\
\hline & Indicados & - Indicação do ministro da Saúde (três representantes) \\
\hline & $\begin{array}{l}\text { Prestadores } \\
\text { privados de } \\
\text { serviços de saúde }\end{array}$ & $\begin{array}{l}\text { - Prestadores privados (dois representantes escolhidos dentre as seguintes entidades: } \\
\text { Federacão Nacional de Estabelecimentos e Serviços de Saúde, Associação Brasileira de } \\
\text { Medicina de Grupo, Federacão Brasileira de Hospitais, Associação Brasileira de } \\
\text { Hospitais e Confederação das Misericórdias do Brasil) }\end{array}$ \\
\hline$\frac{n}{\pi}$ & $\begin{array}{l}\text { Profissionais e } \\
\text { trabalhadores de } \\
\text { saúde }\end{array}$ & $\begin{array}{l}\text { - Médicos (um representante escolhido dentre as seguintes entidades: Conselho Federal de } \\
\text { Medicina, Associação Médica Brasileira Fe Federação Nacional dos Médicos) } \\
\text { - Profissionais de saúde não-médicos (dois representantes) } \\
\text { - Sociedade Brasileira para o Progresso da Ciência (SBPC) }\end{array}$ \\
\hline 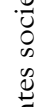 & Empresários & $\begin{array}{l}\text { - Confederação Nacional da Indústria (CNI) } \\
\text { - Confederação Nacional do Comércio (CNC) } \\
\text { - Confederação Nacional da Agricultura (CNA) }\end{array}$ \\
\hline 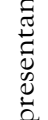 & $\begin{array}{l}\text { Trabalhadores } \\
\text { (não saúde) }\end{array}$ & $\begin{array}{l}\text { - Confederação Nacional dos Trabalhadores na Agricultura (Contag) } \\
\text { - Central Geral dos Trabalhadores (CGT) } \\
\text { - Central Única dos Trabalhadores (CUT) } \\
\end{array}$ \\
\hline \multirow[t]{3}{*}{ 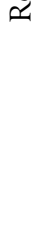 } & $\begin{array}{l}\text { Associações } \\
\text { comunitárias }\end{array}$ & - Conselho Nacional das Associações de Moradores (Conam) (dois representantes) \\
\hline & $\begin{array}{l}\text { Entidades de } \\
\text { portadores de } \\
\text { patologias ou } \\
\text { deficiências }\end{array}$ & $\begin{array}{l}\text { Modificação de } 1992 \\
\text { - Entidades de portadores de patologias } \\
\text { (seis representantes) }\end{array}$ \\
\hline & Igrejas & - Conferência Nacional dos Bispos do Brasil (CNBB) \\
\hline
\end{tabular}

Fonte: Brasil, 1990c, art. 2º Brasil, 1992a, art. 1º. 


\section{Quadro 3 - Composição do Conselho Nacional de Saúde por representan-} tes estatais e societais - 1994-1995

\begin{tabular}{|c|c|c|c|}
\hline \multirow{4}{*}{ 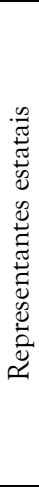 } & \multirow{3}{*}{ Governamentais } & $\begin{array}{l}\text { - Ministério da Educação } \\
\text { - Ministério do Bem-Estar } \\
\text { Social } \\
\text { - Ministério da Previdência } \\
\text { Social }\end{array}$ & - Ministério da Previdência e Assistência Social \\
\hline & & $\left.\begin{array}{l}\text { - Ministério da Fazenda } \\
\text { - Secretaria de Planejamento, } \\
\text { Orçamento e Coordenação } \\
\text { da Presidência da República }\end{array}\right\}$ & $\begin{array}{l}\text { - Ministério do Planejamento e do Orçamento } \\
\text { - Ministério da Agricultura, do Abastecimento e da } \\
\text { Reforma Agrária }\end{array}$ \\
\hline & & \multicolumn{2}{|c|}{$\begin{array}{l}\text { - Ministério da Saúde (dois representantes, sendo um o ministro, presidente do Conselho) } \\
\text { - Ministério do Trabalho } \\
\text { - Conselho Nacional de Secretários de Saúde (Conass) } \\
\text { - Conselho Nacional de Secretários Municipais de Saúde (Conasems) }\end{array}$} \\
\hline & Indicados & \multicolumn{2}{|c|}{ - Indicação do ministro da Saúde (três representantes) } \\
\hline \multirow{7}{*}{ 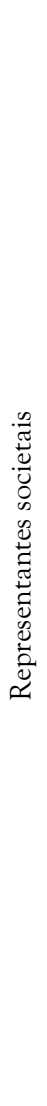 } & $\begin{array}{l}\text { Prestadores } \\
\text { privados de } \\
\text { serviços de saúde }\end{array}$ & \multicolumn{2}{|c|}{ 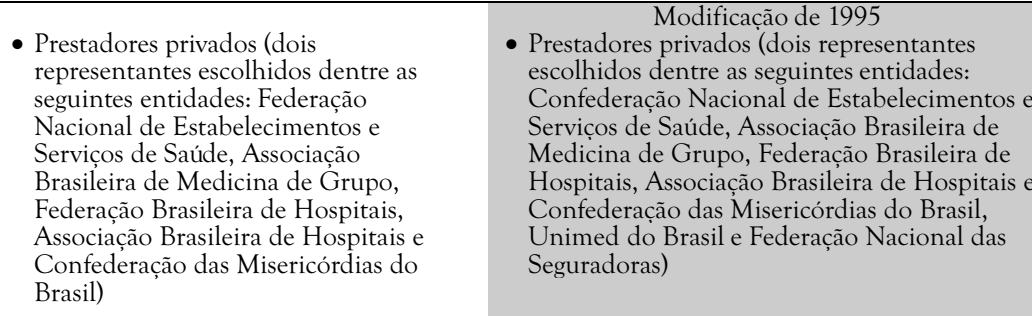 } \\
\hline & $\begin{array}{l}\text { Profissionais e } \\
\text { trabalhadores de } \\
\text { saúde }\end{array}$ & \multicolumn{2}{|c|}{$\begin{array}{l}\text { - Médicos (um representante escolhido dentre as seguintes entidades: Conselho Federal de } \\
\text { Medicina, Associação Médica Brasileira e Federação Nacional dos Médicos) } \\
\text { - Profissionais de saúde não médicos (dois representantes) } \\
\text { - Sociedade Brasileira para o Progresso da Ciência(SBPC) }\end{array}$} \\
\hline & Empresários & \multicolumn{2}{|c|}{$\begin{array}{l}\text { - Confederação Nacional da Indústria (CNI) } \\
\text { - Confederação Nacional do Comércio (CNC) } \\
\text { - Confederação Nacional da Agricultura (CNA) }\end{array}$} \\
\hline & $\begin{array}{l}\text { Trabalhadores } \\
\text { (não saúde) }\end{array}$ & \multicolumn{2}{|c|}{$\begin{array}{l}\text { - Central Geral dos Trabalhadores (CGT) } \\
\text { - Confederação Geral dos Trabalhadores } \\
\text { (CGT) }\end{array}$} \\
\hline & $\begin{array}{l}\text { Associações } \\
\text { comunitárias, } \\
\text { movimentos } \\
\text { sociais e } \\
\text { organizações não } \\
\text { governamentais } \\
\text { (ONGs) }\end{array}$ & \multicolumn{2}{|c|}{$\begin{array}{ll}\text { - Conselho Nacional das Associações } & \text { Modificação de } 1995 \\
\begin{array}{l}\text { de Moradores (Conam) (dois } \\
\text { representantes) }\end{array} & \text { Conselho Nacional das Associações de } \\
& \begin{array}{l}\text { Moradores (Conam) (um representante) } \\
\text { Cenfederação Brasileira de Aposentados e } \\
\text { Pensionistas }\end{array}\end{array}$} \\
\hline & $\begin{array}{l}\text { Entidades de } \\
\text { portadores de } \\
\text { patologias ou } \\
\text { deficiências }\end{array}$ & \multicolumn{2}{|c|}{ - Entidades de portadores de patologias (seis representantes) } \\
\hline & Igrejas & \multicolumn{2}{|c|}{ - Conferência Nacional dos Bispos do Brasil (CNBB) } \\
\hline
\end{tabular}

Fonte: Brasil, 1994, art. 1; Brasil, 1995, art. 1. 


\section{Quadro 4 - Composição do Conselho Nacional de Saúde por representan-} tes estatais e societais - 2003-2006

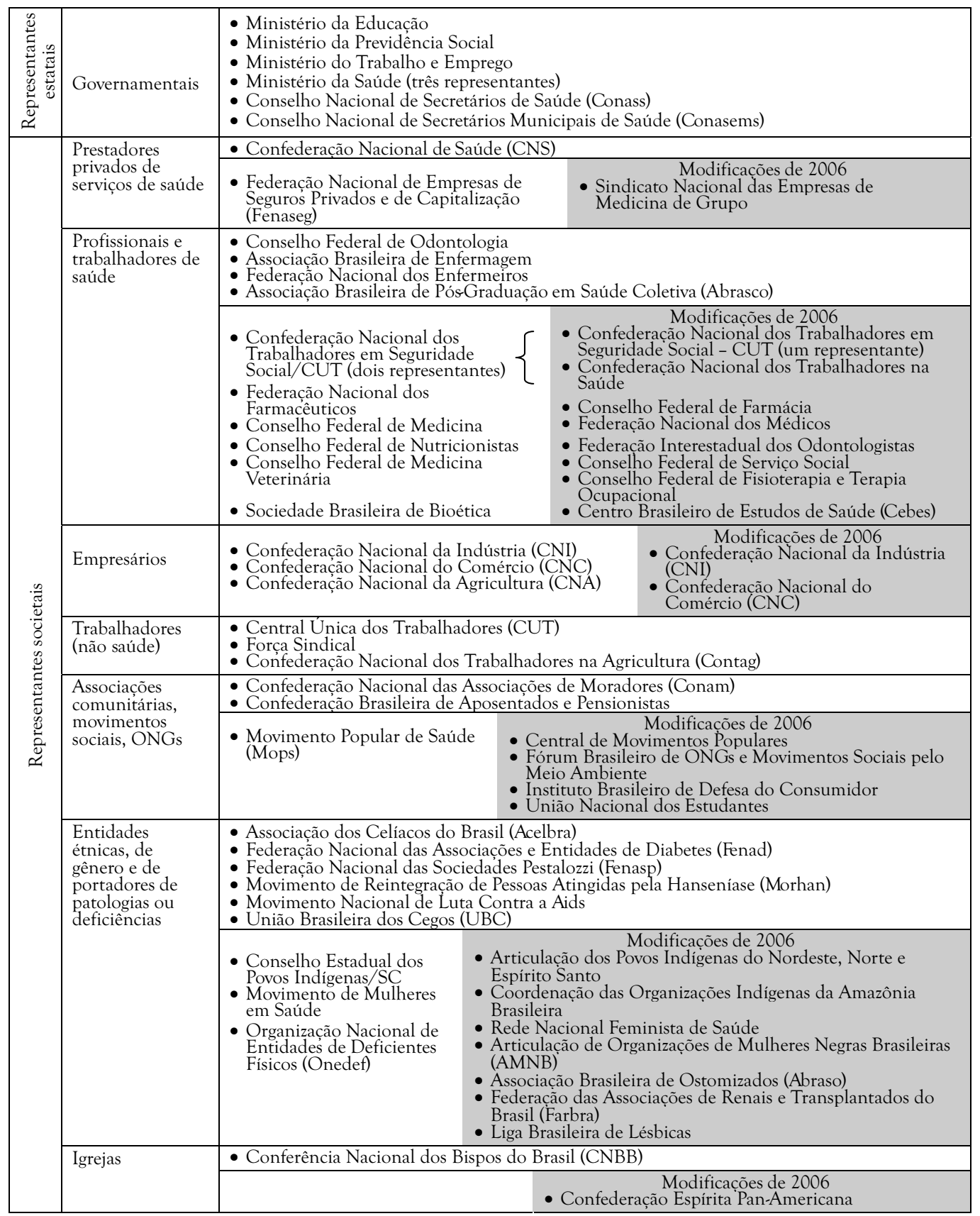

Fonte: Brasil, 2003; Brasil, 2006a. 
Desde 1990 ocorreram dois tipos de mudanças na composição do Con-selho, no que se refere aos 'representantes estatais'. Por um lado, as variações entre os conselheiros provenientes de órgãos do governo federal refletiram mudanças na estrutura ministerial ao longo do período. $O$ número de representantes do Ministério da Saúde (três) e dos secretários estaduais e municipais de Saúde (um e um, respectivamente) manteve-se inalterado ao longo do período. Por outro lado, a partir de 2003, desapareceram os conselheiros de 'notório saber' indicados pelo Ministério da Saúde. Desse modo, extinguia-se uma tradição que persistia desde a criação do primeiro Conselho Nacional de Saúde, ao mesmo tempo que o novo Conselho se consolidava como um espaço público em que interesses sociais organizados eram representados.

Os 'representantes societais' variaram bem mais no período. No cômputo geral, houve diminuição tanto em termos absolutos como em termos relativos no número de representantes de entidades de 'mercado'. O número de conselheiros oriundos de entidades de prestadores privados de serviços não se alterou, mas em 1995 as empresas de seguro de saúde passaram a integrar o plenário do Conselho. Isso refletia sua importância crescente como financiadoras e compradoras de serviços no mercado da saúde no país. Já os empresários com interesses não estritamente vinculados ao setor saúde tiveram seu número de representantes reduzido. Na maior parte do período, eram três conselheiros oriundos de organizações empresariais. Após a alteração da composição ocorrida em 2006, entretanto, o representante da Confederação Nacional da Agricultura foi excluído, restando apenas aqueles provenientes da Confederação Nacional do Comércio e da Confederação Nacional da Indústria.

Em contraste, o número e a proporção de representantes de entidades 'sociais', da sociedade civil, cresceram no período. Com um crescimento de $200 \%$, os conselheiros provenientes de organizações profissionais e de trabalhadores de saúde passaram de quatro, em 1990, para 12, em 2006. Sozinhos, eles somavam um quarto do total de votos nas reuniões plenárias do Conselho. Observe-se que os médicos mantiveram, ao longo do periodo, apenas um representante no fórum.

O número de representantes provenientes de associações comunitárias, movimentos sociais e organizações não governamentais (ONGs) também aumentou 200\%, enquanto os representantes de entidades étnicas, de gênero e de portadores de patologias ou deficiências tiveram o expressivo 
crescimento de $160 \%$. Entretanto, enquanto a primeira categoria tinha apenas dois conselheiros, em 1990, e passou a ter seis, em 2006, a segunda tinha cinco, em 1990, e passou a ter 13, no final do período. Desse modo, mesmo com um crescimento maior, os representantes das associações comunitárias, movimentos sociais e ONGs, em 2006, perfaziam 12\% do total de conselheiros, enquanto os representantes das entidades étnicas, de gênero e de portadores de patologias ou deficiências atingiam 27\% desse total, ou seja, os últimos sozinhos detinham pouco mais que um quarto do total de votos nas reuniões plenárias do Conselho.

O número de conselheiros oriundos de entidades de trabalhadores, não especificamente da área da saúde, se manteve praticamente estável, ao longo do período. As variações na quantidade de representantes nessa categoria deveram-se, provavelmente, às mudanças ocorridas na organização das centrais sindicais no país. Predominou, no período, o número de três conselheiros. A exceção foi o ano de 2004, quando havia quatro representantes de centrais sindicais.

Com 12 e 13 conselheiros, respectivamente, os representantes de entidades de profissionais e trabalhadores de saúde e de entidades étnicas, de gênero e de portadores de patologias ou deficiências somados detinham, em 2006, mais da metade dos votos no fórum (52\%, 25 em 48). A importância que os dois grupos passaram a ter no Conselho está relacionada, ao menos em parte, à ampliação de sua importância relativa e visibilidade no âmbito da sociedade civil organizada, no Brasil, a partir da década de 1990 .

Embora tenham crescido menos que em outros setores da economia, os empregos em saúde no Brasil aumentaram, em média, 3,79\% no período 2003-2005 (Observatório de Recursos Humanos em Saúde, 2006). No final de 2005, o estoque de empregos em serviços de saúde era de 1,137 milhão (Observatório de Recursos Humanos em Saúde, 2006). Se a eles forem somados os empregos em atividades industriais e comerciais relacionadas à produção de bens como medicamentos e insumos hospitalares, o número de pessoas empregadas na área sobe para mais de 2,5 milhões (Biasoto Júnior, 2007). Os profissionais e os trabalhadores em saúde cresciam em importância relativa no mercado de trabalho.

O protagonismo político no conselho de representantes do Fórum das Entidades Nacionais dos Trabalhadores da Área da Saúde (Fentas) está relacionado não somente a tais circunstâncias, mas também à ação deliberada desses conselheiros no sentido de assumir a direção política do fórum. Em 
torno de conselheiros vinculados ao Fentas organizou-se uma nova comunidade de política na área da saúde. Os princípios fundadores do SUS continuavam integrando o conjunto de suas propostas, mas a eles acrescia-se a defesa da provisão exclusivamente pública de serviços e dos interesses de categorias de profissionais e de trabalhadores da saúde, não médicos, ${ }^{12} \mathrm{em}$ oposição a entidades que defendiam os interesses da categoria médica. Os gestores, profissionais de saúde e acadêmicos identificados com o movimento sanitário, que liderara o processo de reforma do sistema brasileiro de saúde nos anos 80 e 90, eram vistos pela nova comunidade como integrantes de um grupo que renunciara aos verdadeiros ideais reformistas (G. S., entrevista, 4/5/2006).

Oaumento expressivo no número de representantes de entidades étnicas, de gênero e de portadores de patologias ou deficiências, por sua vez, está relacionado à multiplicação de atores sociais organizados e à variedade de temas específicos que passaram a integrar o debate político nacional. Questões antes politicamente invisíveis e consideradas como 'normais' relacionadas a desigualdades decorrentes da cor da pele, da etnia, do gênero sexual, da orientação sexual, da preferência religiosa, do fato de a pessoa ser portadora de determinadas patologias ou deficiências - passaram a fazer parte da agenda pública de discussão, marcadamente na área da saúde. No mesmo sentido pode ser entendida a inclusão no Conselho de um representante da Confederação Espírita Pan-Americana. Se, por um lado, isso talvez reflita a diminuição relativa da população católica no país; por outro, pode estar relacionado a uma tendência à maior aceitação social da pluralidade religiosa. Assim, as reivindicações, as políticas implementadas e os canais públicos ou ocultos em que se negociavam decisões sobre questões de interesse de entidades étnicas, de gênero e de portadores de patologias ou deficiências e de entidades religiosas não católicas expressavam a emergência de um novo padrão organizativo da sociedade civil brasileira.

A Tabela 1 e o Gráfico 1 mostram o crescimento expressivo do número de conselheiros das categorias: organizações de profissionais e trabalhadores de saúde; entidades étnicas, de gênero e de portadores de patologias ou deficiências; e associações comunitárias, movimentos sociais e ONGs.

\footnotetext{
12 Embora entidades médicas integrem o Fentas, as posições politicas do Fórum se opõem àquelas defendidas pelas organizações que lutam pelos interesses da categoria médica.
} 
Entre 2003 e 2006, eles já correspondiam a 27\% (11), 7\% (três) e 22\% (nove), respectivamente, do total de conselheiros, perfazendo em conjunto 56\% (23) desse total. A partir da última alteração na composição, em 2006 , eles passaram a representar $25 \%$ (12), $12 \%$ (seis) e $27 \%$ (13), respectivamente, aumentando sua participação relativa para $64 \%$ (31) do total de conselheiros.

Tabela 1 - Número de conselheiros do Conselho Nacional de Saúde por tipos de representantes - 1990, 1992, 1994, 1995, 2003, 2006

\begin{tabular}{lrrrrrr}
\hline \multicolumn{1}{c}{ Tipos de participantes } & 1990 & 1992 & 1994 & 1995 & 2003 & 2006 \\
\hline Governamentais & 8 & 9 & 10 & 9 & 8 & 8 \\
Indicados & 3 & 3 & 3 & 3 & 0 & 0 \\
Prestadores privados de serviços de saúde & 2 & 2 & 2 & 2 & 2 & 2 \\
Profissionais e trabalhadores de saúde & 4 & 4 & 4 & 4 & 11 & 12 \\
Empresários & 3 & 3 & 3 & 3 & 3 & 2 \\
Trabalhadores (não saúde) & 3 & 3 & 4 & 3 & 3 & 3 \\
Associações comunitárias, movimentos sociais, ONGs & 2 & 2 & 2 & 2 & 3 & 6 \\
Entidades étnicas, de gênero e de portadores de patologias ou & & & & & & \\
deficiências & 5 & 6 & 6 & 6 & 9 & 13 \\
Igrejas & 1 & 1 & 1 & 1 & 1 & 2 \\
\hline Total & 31 & 33 & 35 & 33 & 40 & 48 \\
\hline
\end{tabular}

Fonte: Brasil, 1990c, art. 2; Brasil, 1992a, art. 1; Brasil, 1994, art. 1; Brasil, 1995, art. 1; Brasil, 2003; Brasil, 2006a. 
Gráfico 1 - Número de conselheiros do Conselho Nacional de Saúde por tipos de representantes - 1990, 1992, 1994, 1995, 2003, 2006

Igrejas

Entidades étnicas, de gênero e de portadores de patologias ou deficiências

$\square$ Associações comunitárias, movimentos sociais, ONGs

田 Trabalhadores (não saúde)

$\square$ Empresários

皿血 Profissionais, trabalhadores de saúde

$\square$ Prestadores privados de serviços de saúde indicados

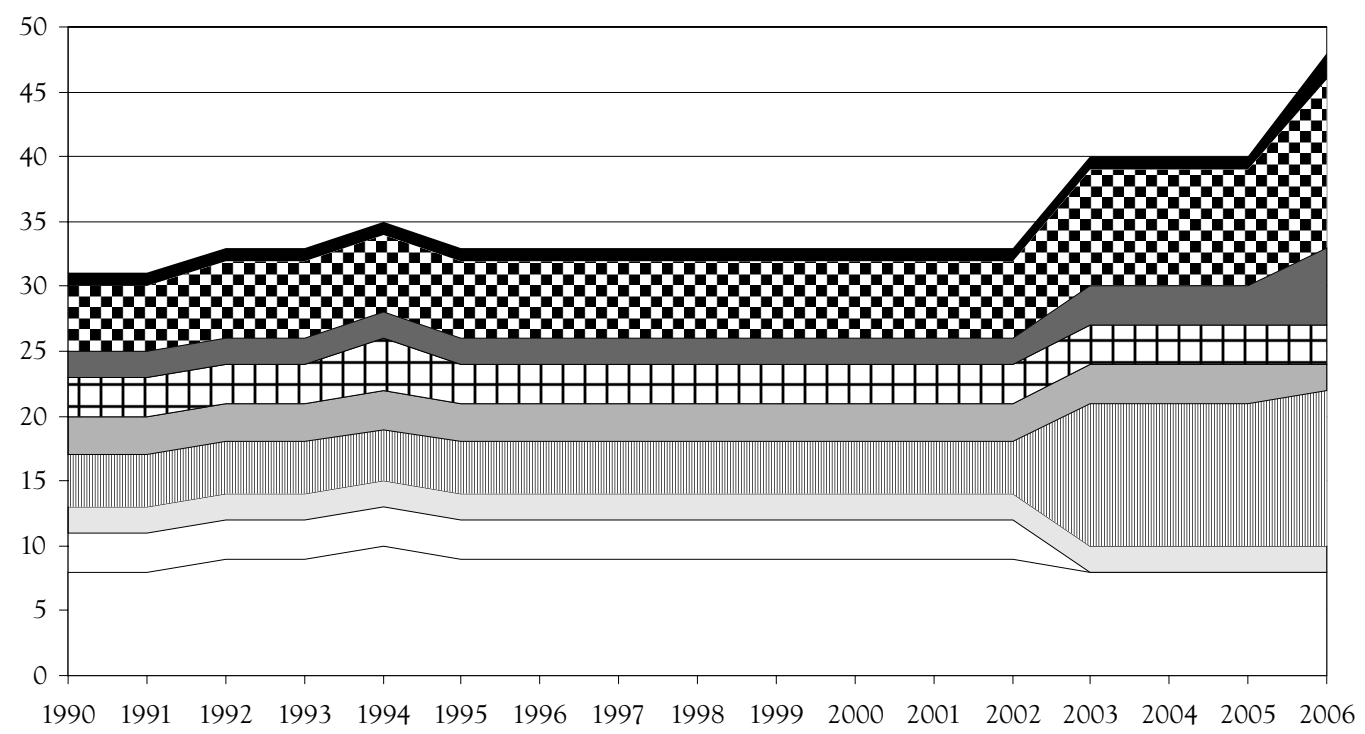

Fonte: Brasil, 1990c, art. 2; Brasil, 1992a, art. 1; Brasil, 1994, art. 1; Brasil, 1995, art. 1; Brasil, 2003; Brasil, 2006a.

Agregando essas categorias de representantes aos três grandes tipos de participantes aqui focalizados - governamentais, de mercado e sociais ${ }^{13}$ - e observando a evolução no número de conselheiros (Tabela 2 e Gráfico 2), constata-se que houve grande crescimento no número de conselheiros provenientes de organizações sociais. Ao longo do periodo, eles aumentaram sua participação no Conselho em 140\% (15 para 36), em contraste com os representantes governamentais e de entidades de mercado que perderam assentos no Conselho na proporção de $27 \%$ (11 para oito) e 20\% (cinco para quatro), respectivamente.

\footnotetext{
${ }^{13}$ A classificação utilizada é a seguinte: 'governamentais' inclui governamentais e indicados; de 'mercado' compreende prestadores privados de serviços de saúde e empresários; 'sociais' abrange profissionais, trabalhadores de saúde; trabalhadores (não saúde); associações comunitárias, movimentos sociais, ONGs; entidades étnicas, de gênero e de portadores de patologias ou deficiências; igrejas.
} 
Tabela 2 - Número de conselheiros do Conselho Nacional de Saúde por representantes governamentais, de mercado e sociais - 1990, 1992, 1994, 1995, 2003, 2006

\begin{tabular}{lrrrrrr}
\hline Tipos de participantes & 1990 & 1992 & 1994 & 1995 & 2003 & 2006 \\
\hline Governamentais & 11 & 12 & 13 & 12 & 8 & 8 \\
Mercado & 5 & 5 & 5 & 5 & 5 & 4 \\
Sociais & 15 & 16 & 17 & 16 & 27 & 36 \\
\hline Total & 31 & 33 & 35 & 33 & 40 & 48 \\
\hline
\end{tabular}

Fonte: Brasil, 1990c, art. 2º Brasil, 1992a, art. 1º Brasil, 1994, art. 1º; Brasil, 1995, art. ${ }^{\circ}$; Brasil, 2003; Brasil, 2006a.

Gráfico 2 - Número de conselheiros do Conselho Nacional de Saúde por representantes governamentais, de mercado e sociais - 1990, 1992, 1994, 1995, 2003, 2006

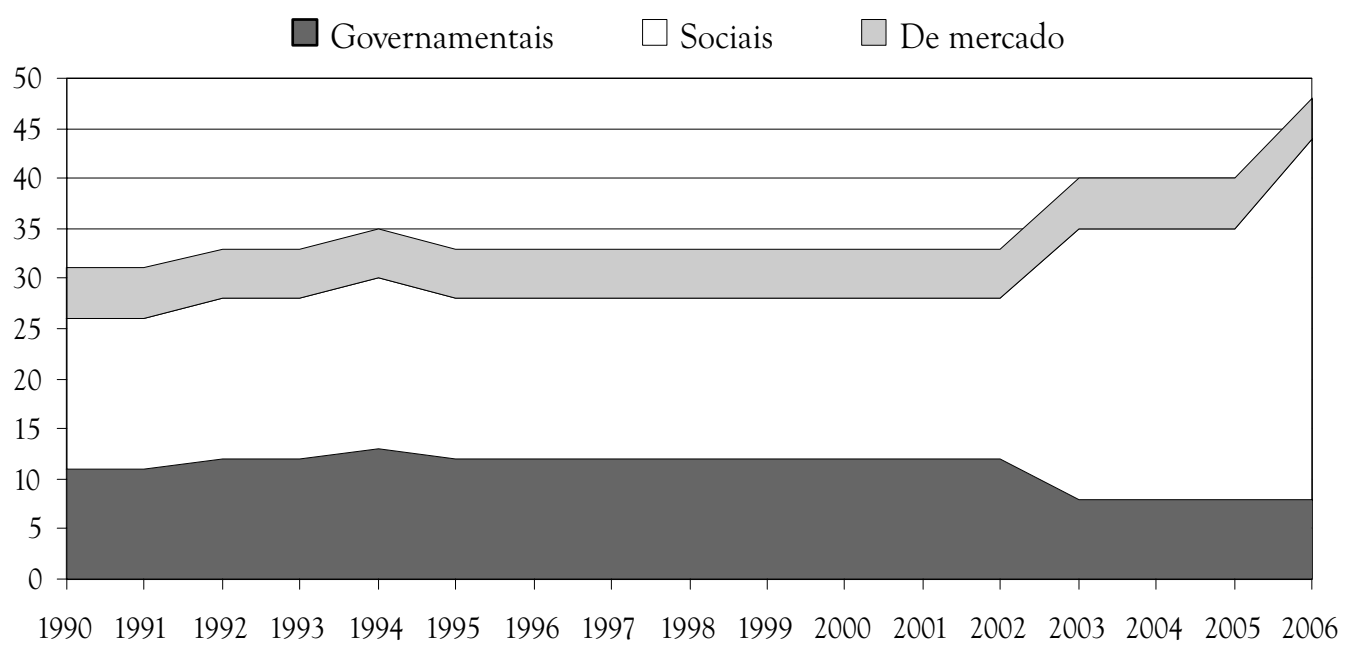

Fonte: Brasil, 1990c, art. 2º; Brasil, 1992a, art. 1; Brasil, 1994, art. 1; Brasil, 1995, art. 1º; Brasil, 2003; Brasil, 2006a.

A expressiva presença de representantes de entidades sociais é uma indicação de como se distribuía o poder no fórum. No novo Conselho Nacional de Saúde, os conselheiros que representavam profissionais e trabalhadores de saúde; associações comunitárias, movimentos sociais, ONGs; e entidades étnicas, de gênero e de portadores de patologias ou deficiências passaram a controlar as principais instâncias decisórias do Conselho. No entanto, isso pode significar, paradoxalmente, que o poder do fórum na arena decisória da área diminuiu ao longo do período. 
O decréscimo no número de representantes governamentais no Conselho pode indicar que eles passaram a ter menor capacidade de influir nas decisões tomadas no fórum, mas que ao mesmo tempo as principais decisões sobre a política de saúde estavam sendo tomadas em outros espaços decisórios. Tanto os conselheiros entrevistados (L. M., entrevista, 16/1/2006; W. J., entrevista, 20/9/2006) quanto a literatura (Santos \& Gerschman, 2006; Levcovitz, Lima \& Machado, 2001; Menicucci, 2004) salientam que as comissões intergestores criadas no início da década de 1990 (Brasil, 1991a, 1993) passaram a ser as principais arenas institucionais de tomada de decisões sobre a política de saúde no país. Isto teria afetado negativamente a capacidade do Conselho Nacional de Saúde de se consolidar como um fórum central de decisão sobre a política de saúde nacional.

No início da década de 1990, as dificuldades de gestão de um sistema único de saúde em um estado federativo, como é o caso brasileiro, desafiavam os gestores e a comunidade de política reformista a encontrar mecanismos que viabilizassem a coordenação vertical e horizontal das ações implementadas de forma descentralizada. No Conselho, na época recémestruturado, travavam-se as principais discussões e tomava-se grande parte das decisões sobre política de saúde. A proposta de criação das comissões bipartites, nos estados, e tripartite, no nível federal, como instâncias colegiadas de pactuação e articulação entre os gestores nos níveis de governo correspondentes, foi articulada no Conselho por representantes dos gestores municipais e estaduais, interessados em aumentar o poder de decisão dos níveis subnacionais de governo sobre a gerência e a operacionalização do sistema. Conforme afirmou um conselheiro, na época dirigente do Conselho Nacional de Secretários Municipais de Saúde (Conasems), "na primeira reunião do novo Conselho, em abril de 91, eu entro com a proposta de criação da Tripartite. Então essa [reunião] é o início da resolução de criação da Tripartite e da Bipartite” (L. M., entrevista, 16/1/2006).

O Conselho Nacional de Saúde propôs a criação de uma comissão especial para "discutir e elaborar propostas para implantação e operacionalização do Sistema Único de Saúde (...) a ser constituída pelas três instâncias gestoras governamentais" (Brasil, 1991b). O Ministério da Saúde, seguindo a recomendação do Conselho, criou em 1991 "uma comissão técnica com o objetivo de discutir e elaborar propostas para implantação e operacionalização do Sistema Único de Saúde”, que viria a ser conhecida como a Comissão Intergestores Tripartite (CIT) (Brasil, 1991a). 
A norma operacional básica de 1993 (NOB 01/93) (Brasil, 1993) produziu duas grandes alterações no sistema de saúde brasileiro que induziram, de fato, à consolidação do processo de reforma: o aprofundamento da municipalização e a consolidação das instâncias colegiadas de coordenação vertical e horizontal de gestão. Essa norma foi elaborada no início do governo Itamar Franco, logo após o processo político que levara ao impedimento do presidente Fernando Collor. Na área da saúde, os novos dirigentes federais eram claramente identificados com o movimento sanitário e mais permeáveis às propostas de aprofundamento da municipalização e descentralização do sistema, se comparados aos gestores da administração Collor. A contragosto, os dirigentes municipais de saúde haviam aderido à municipalização de acordo com as regras impostas pelas normas operacionais anteriores - NOB de 1991 (Brasil, 1991c) e NOB de 1992 (Brasil, 1992b) consideradas centralizadoras (Levcovitz, Lima \& Machado, 2001). No novo contexto político, eles pressionavam pela edição de normas que viabilizassem a descentralização, principalmente em relação à decisão sobre a transferência de recursos financeiros da esfera federal para a municipal de gestão.

A NOB 01/93 (Brasil, 1993) foi o resultado de discussões intensas travadas durante seis meses entre integrantes do Conselho Nacional de Saúde, da Comissão Intergestores Tripartite e do Grupo Especial de Descentralização, criado pelo Ministério da Saúde em 1993.14 Ela estabeleceu a criação de níveis transitórios, coexistentes e crescentes de gestão estadual e municipal, com competências e capacidades administrativas e financeiras distintas, denominados: incipiente, parcial e semiplena. Criou a Comissão Intergestores Tripartite, federal, e as Comissões Intergestores Bipartites, nos estados. A NOB 01/93 estabeleceu assim o desenho institucional de planejamento e de gestão do SUS até hoje vigente, caracterizado pela descentralização e pela existência desses fóruns permanentes de coordenação vertical e horizontal do sistema. Embora não tenha alterado o desenho institucional básico implantado pela NOB 01/93, a NOB 01/96 (Brasil, 1996) modificou alguns aspectos nas relações federativas entre governos federal, estaduais e municipais na área da saúde. Dentre eles se destacam a criação de mecanismos de transferência de recursos financeiros da

\footnotetext{
${ }^{14}$ O Grupo Especial de Descentralização era integrado por representantes do Ministério da Saúde, do Conselho Nacional de Secretários Municipais de Saúde (Conasems) e do Conselho Nacional de Secretários Estaduais de Saúde (Conass) (Levcovitz, Lima \& Machado, 2001).
} 
esfera federal para as subnacionais em programas ou em áreas especificas de interesse do governo federal - Piso da Atenção Básica Variável - e a classificação dos níveis de gestão em apenas dois: Gestão Plena da Atenção Básica e Gestão Plena do Sistema Municipal.

A institucionalização das Comissões Intergestores Tripartite e Bipartites $^{15}$ teve impacto sobre o Conselho Nacional de Saúde. A partir da segunda metade da década de 1990, "praticamente todas as questões que dizem respeito ao financiamento, à descentralização da estrutura gestora do SUS e à estruturação e funcionamento do sistema de saúde" são discutidas nessas comissões (Levcovitz, Lima \& Machado, 2001: 278). Para conselheiros, representantes de entidades de profissionais e trabalhadores de saúde, as Comissões teriam tirado o protagonismo do Conselho na definição das políticas de saúde (J. R., entrevista, 31/5/2006; N. G., entrevista, 31/5/2006; Q. F., entrevista, 2/6/2006). Para os gestores idealizadores dessas comissões, havia a necessidade de coordenação das ações nos três níveis de governo, possibilitando a implementação de políticas e ações nacionais de forma articulada e organizada (L. M., entrevista, 16/1/2006; W. J, entrevista, 20/9/2006). Para os últimos, o Conselho seria um espaço de discussões e deliberações sobre a natureza das políticas. Sua estrutura de funcionamento e sua composição não permitiriam que ele cumprisse as funções exercidas pelas Comissões Tripartite e Bipartites. Mesmo assim eles reconheciam que houve, em alguma medida, sobreposição de competências e confusão de papéis.

A Tripartite e as Bipartites foram um mal necessário. (...) tanto as Bipartites quanto a Tripartite agilizaram as decisões, especialmente na distribuição de recursos e na implantação de programas. Mas houve um choque de atribuições, um choque de competências: o que seria competência da Tripartite e o que seria competência do Conselho. (W. J, entrevista, 20/9/2006)

A redução absoluta e relativa no número de representantes dos gestores que integravam oficialmente o Conselho, entre 1990 e 2006, e o crescimento no número de representantes de organizações da sociedade civil podem estar relacionados às mudanças no desenho institucional do sistema,

\footnotetext{
${ }^{15}$ As Comissões Tripartite e Bipartites Intergestores são paritárias - tripartites e bipartites, respectivamente -, compostas por representantes do Ministério da Saúde, do Conselho Nacional de Secretários de Saúde (Conass) e do Conselho Nacional de Secretários Municipais de Saúde (Conasems), no caso da primeira, e por representantes das secretarias estaduais de Saúde e dos secretários ou dirigentes municipais de Saúde, no caso das segundas (Brasil, 1993).
} 
que colocaram as instâncias de pactuação federativa no centro do processo decisório. Os gestores não teriam tanto interesse em controlar as atividades do Conselho Nacional de Saúde, uma vez que concentravam sua atuação nas Comissões Intergestoras. No entanto, os atores sociais que participavam do Conselho, e que passaram gradativamente a liderar os seus trabalhos, optaram por uma estratégia que visava a ampliar o seu controle sobre o fórum, e não a fortalecê-lo como espaço decisório na arena política da área da saúde. Suas ações foram no sentido de acabar com a vaga cativa dos médicos e manter reduzido o número de representantes de gestores e de entidades de mercado, ao mesmo tempo que pressionavam para retirar do ministro da Saúde a prerrogativa de presidir o fórum (G. S., entrevista, 4/5/2006; M. C., entrevista, 23/5/2006; N. G., entrevista, 31/5/2006; P. G., entrevista, 31/5/2006; Q. F., entrevista, 2/6/2006).

Assim, temas relacionados à composição e coordenação seguiram ocupando grande espaço nas discussões do Conselho. $\bigcirc$ núcleo da polêmica dizia respeito, especialmente, a dois pontos: a manutenção da presidência como prerrogativa do ministro da Saúde e a permanência no plenário do fórum de conselheiros provenientes de entidades pouco representativas. Propostas de reformulação no Regimento Interno que modificassem esses pontos foram objetos de discussão constante durante o ano de 2005 (V. N., entrevista, 1\%/9/2006; W. J., entrevista, 20/9/2006).

Em julho de 2006, após quase dois anos de intensos debates e negociações, foram aprovadas a nova composição e as mudanças na coordenação do Conselho (Brasil, 2006b). Pela primeira vez, o cargo de presidente deixou de ser uma prerrogativa do ministro da Saúde e tornou-se eletivo. Qualquer conselheiro titular (inclusive o ministro) passou a poder concorrer à presidência do fórum.

\section{Considerações Finais}

O Conselho Nacional de Saúde foi criado em 1937 e sofreu reformulações sucessivas até a última grande mudança de 2006. Tais modificações redefiniam suas competências específicas e sua composição, refletindo transformações nas concepções de saúde dos gestores federais da área, nas políticas de saúde e no conjunto de atores envolvidos no financiamento, na provisão e na gestão dessas políticas. Embora seja possível identificar traços de continuidade entre determinadas características dessas conformações 
do fórum com aquelas encontradas no Conselho criado em 1990, foram as reformulações de 1976/1977 e de 1987 que anunciaram o desenho que o 'novo' Conselho Nacional de Saúde viria a ter. Em 1976/1977, foram criadas a Secretaria Executiva e as câmaras técnicas, antecessoras das comissões e dos grupos de trabalho constituídos na década de 1990. Com as alterações de 1987, o Conselho passou a ser órgão deliberativo, mudando sua função legal na área da saúde do país. Entretanto, esse Conselho pouco se envolveu nos debates sobre a reforma do sistema da saúde, então em curso. A grande arena de discussões foi a Comissão Nacional de Reforma Sanitária, criada em 1986. Somente a partir de 1990, e especialmente no início da década, o Conselho Nacional de Saúde constituiu-se como um espaço politico no qual interesses sociais organizados eram representados e discutiamse os rumos da politica nacional de saúde, buscando a criação de consensos ou explicitação de posições conflitantes.

Entre 1990 e 2006, as funções do Conselho permaneceram as mesmas, do ponto de vista legal, mas sua composição e seu papel na arena de decisão política da área modificaram-se. Tanto em termos relativos como em termos absolutos, cresceu o número de conselheiros provenientes de organizações da sociedade civil, principalmente das categorias aqui denominadas como de organizações de profissionais e trabalhadores de saúde; de entidades étnicas, de gênero e de portadores de patologias ou deficiências; e de associações comunitárias, movimentos sociais e ONGs. Simultaneamente, diminuiu a participação dos representantes governamentais e de mercado.

Legalmente, o fórum passou a ser deliberativo e responsável pela formulação de estratégias e pelo controle da execução da política de saúde nacional, com uma proporção crescente de conselheiros provenientes de entidades da sociedade civil. Se, por um lado, isso é uma indicação de que esses conselheiros podem ter aumentado seu poder no interior do Conselho; por outro, o poder do Conselho sobre o processo decisório da área pode ter diminuído.

Mudanças no desenho institucional do sistema resultaram na criação das comissões intergestores e no aprofundamento do processo de municipalização. Com a institucionalização das Comissões Intergestores Tripartite e Bipartites, ali passou a ser discutida a maior parte das questões relativas ao financiamento, descentralização da estrutura gestora do SUS e estruturação e funcionamento do sistema de saúde. Essas instâncias de pactuação federativa foram colocadas no centro da arena política da área, reduzindo o interesse de gestores 
e prestadores de serviço em controlar as atividades do Conselho, visto a partir de então como fórum decisório secundário.

Os atores sociais, que passaram gradativamente a liderar os trabalhos do Conselho, por sua vez, optaram por ampliar seu controle sobre ele. A estratégia adotada desdobrava-se em dois objetivos: eles buscavam a redução da importância relativa de representantes da categoria médica, de entidades de mercado e dos gestores, no interior do Conselho, não permitindo a expansão do número desses representantes ou provocando a sua diminuição, e exerciam pressão constante sobre o Ministério da Saúde para que fosse extinta a prerrogativa ministerial de presidir o Conselho. Tal estratégia pode ter colaborado para a consolidação de um papel secundário do fórum, no entanto, favorecia a estruturação de bases materiais e organizativas de sustentação de uma nova comunidade de política - liderada por profissionais e trabalhadores da saúde, não médicos, os quais atuavam no Conselho - que se opunha à comunidade reformadora: o movimento sanitário. O Conselho Nacional, com sua capacidade de influir sobre os conselhos estaduais e municipais, tornava-se o principal veículo de consolidação da nova comunidade.

\section{REFERÊNCIAS}

AROUCA, S. Implementação da reforma sanitária através do Suds. Saúde em Debate, 22: 49-54, out. 1988.

BIASOTO JÚNIOR, G. Atenção básica e emprego em saúde: alguns elementos e potencialidades. Disponivel em: $<$ http://164.41.105.3/portalnesp/ojs-2.1.1/index.php/ tempus/article/viewFile/389/372>. Acesso em: 16 dez. 2007.

BRASIL. Lei n. 378, de 13 de janeiro de 1937. Dá nova organização ao Ministério da Educação e Saúde Pública.

BRASIL. Decreto n. 34.596, de 16 de novembro de 1953. Aprova o Regulamento do Ministério da Saúde, criado pela lei n. 1.920, de 25 de julho de 1953, e dá outras providências. BRASIL. Decreto n. 34.347, de 8 de abril de 1954. Regulamenta a composição, funções e a periodicidade das reuniões do Conselho Nacional de Saúde.

BRASIL. Decreto n. 45.913, de 29 de abril de 1959. Modifica o regulamento do Conselho Nacional de Saúde.

BRASIL. Decreto n. 47.793, de 11 de fevereiro de 1960. Dispõe sobre a composição e sobre a Secretaria Executiva do Conselho Nacional de Saúde.

BRASIL. Decreto n. 847, de 5 de abril de 1962. Dispõe sobre a função do Conselho Nacional de Saúde, amplia o número de conselheiros e mantém a coordenação do Conselho como prerrogativa ministerial. 
BRASIL. Decreto n. 55.242, de 18 de dezembro de 1964. Reestrutura o Conselho Nacional de Saúde.

BRASIL. Decreto n. 55.642, de 27 de janeiro de 1965. Altera o decreto n. 55.242, de 18 de dezembro de 1964, que reestruturou o Conselho Nacional de Saúde.

BRASIL. Decreto n. 67.300, de 30 de setembro de 1970. Dispõe sobre a função do Conselho Nacional de Saúde, altera o número de conselheiros e mantém a coordenação do Conselho como prerrogativa ministerial.

BRASIL. Decreto n. 68.806, de 25 de junho de 1971. Institui a Central de Medicamentos (Ceme).

BRASIL. Lei n. 6.229, de 17 de julho de 1975. Dispõe sobre a organização do Sistema Brasileiro de Saúde.

BRASIL. Decreto n. 79.056, de 30 de dezembro de 1976. Dispõe sobre a composição do Conselho Nacional de Saúde e amplia o número de conselheiros.

BRASIL. Ministério da Saúde. Portaria n. 360, de 30 de setembro de 1977. Aprova o Regimento Interno do Conselho Nacional de Saúde.

BRASIL. Ministério da Saúde. Portaria n. 204, de 4 de maio de 1978. Aprova o Regimento Interno das Câmaras Técnicas do Conselho Nacional de Saúde.

BRASIL. Ministério da Saúde. Portaria n. 2, de 22 de agosto de 1986a. Constitui a Comissão Nacional da Reforma Sanitária, com a finalidade de analisar as dificuldades identificadas no funcionamento da rede nacional de serviços de saúde e sugerir opções para a nova estrutura organizacional do sistema.

BRASIL. Decreto n. 93.076, de 6 de agosto de 1986b. Cria Comissão Interministerial incumbida de propor a reformulação do Conselho Nacional de Saúde.

BRASIL. Ministério da Saúde Relatório Final da 8a Conferência Nacional de Saúde. Brasília: Ministério da Saúde, 1987a.

BRASIL. Decreto n. 93.333, de 14 de janeiro de 1987b. Dispõe sobre a organização e atribuições do Conselho Nacional de Saúde e dá outras providências.

BRASIL. Constituição da República Federativa do Brasil, 5 de outubro de 1988.

BRASIL. Lei n. 8.080, de 19 de setembro de 1990a. Dispõe sobre as condições para a promoção, proteção e recuperação da saúde, a organização e o funcionamento dos serviços correspondentes e dá outras providências.

BRASIL. Lei n. 8.142, de 28 de dezembro de 1990b. Dispõe sobre a participação da comunidade na gestão do Sistema Único de Saúde (SUS).

BRASIL. Decreto n. 99.438, de 7 de agosto de 1990c. Dispõe sobre a organização e atribuições do Conselho Nacional de Saúde e dá outras providências.

BRASIL. Ministério da Saúde. Portaria n. 1.180, de 22 de julho de 1991a. Cria a Comissão Técnica com o objetivo de discutir e elaborar propostas para implantação e operacionalização do Sistema Único de Saúde, incluindo as questões de gerenciamento e financiamento do SUS. 
BRASIL. Conselho Nacional de Saúde. Resolução n. 2, de 26 de abril de 1991b. Recomenda ao ministro da Saúde a constituição de uma comissão especial para elaborar propostas na implantação e operacionalização do SUS.

BRASIL. Ministério da Saúde. Norma Operacional Básica do Sistema Único de Saúde (NOB-SUS) n. 01/91. Brasília: Ministério da Saúde, 1991c.

BRASIL. Decreto n. 571, de 22 de junho de 1992a. Altera o artigo 2 do decreto $n$. 99.438, de 7 de agosto de 1990, que dispõe sobre a composição do Conselho Nacional de Saúde.

BRASIL. Ministério da Saúde. Norma Operacional Básica do Sistema Único de Saúde (NOB-SUS) n. 01/92. Brasília: Ministério da Saúde, 1992b.

BRASIL. Ministério da Saúde. Norma Operacional Básica do Sistema Único de Saúde (NOB-SUS) n. 01/93, de 20 de maio de 1993.

BRASIL. Decreto n. 1.353, de 29 de dezembro de 1994. Altera o artigo $2^{\circ}$ do decreto n. 99.438, de 7 de agosto de 1990, que dispõe sobre a composição do Conselho Nacional de Saúde.

BRASIL. Decreto n. 1.448, de 6 de abril de 1995. Altera o artigo 2o do decreto n. 99.438, de 7 de agosto de 1990, que dispõe sobre a composição do Conselho Nacional de Saúde.

BRASIL. Ministério da Saúde. Norma Operacional Básica do Sistema Único de Saúde (NOB-SUS) n. 01/96, de 6 de novembro de 1996.

BRASIL. Decreto n. 4.878, de 18 de novembro de 2003. Dispõe sobre a composição do Conselho Nacional de Saúde e dá outras providências.

BRASIL. Decreto n. 5.839, de 11 de julho de 2006a. Dispõe sobre a organização, as atribuições e o processo eleitoral do Conselho Nacional de Saúde e dá outras providências.

BRASIL. Conselho Nacional de Saúde. Resolução n. 361, de 12 de julho de 2006b. Dispõe sobre o processo eleitoral do Conselho Nacional de Saúde.

CARDOSO, F. H. Autoritarismo e Democratização. Rio de Janeiro: Paz e Terra, 1975.

CÔRTES, S. M. V. User Participation and Reform of the Brazilian Health System: the case of Porto Alegre, 1995. Tese de Doutorado, Londres: Department of Social Policy and Administration, London School of Economics and Political Science.

HEIMANN, L. S. et al. O Município e a Saúde. São Paulo: Hucitec, 1992.

LEVCOVITZ, E.; LIMA, L. D.; \& MACHADO, C. V. Política de saúde nos anos 90: relações intergovernamentais e o papel das normas operacionais básicas. Ciência $\mathfrak{E}$ Saúde Coletiva, 6(2): 269-291, 2001.

MENICUCCI, T. M. G. Público e privado na política de assistência à saúde no Brasil. In: ENCONTRO DA ASSOCIAÇÃO BRASILEIRA DE CIÊNCIA POLÍTICA (ABCP), 4, 2004, Rio de Janeiro. Anais... Rio de Janeiro: ABCP, 2004.

OBSERVATÓRIO DE RECURSOS HUMANOS EM SAÚDE. Plano Diretor. Evolução do Emprego em Saúde entre 2000 e 2005. Brasília, dez. 2006. 
OLIVEIRA, J. A. A. \& TEIXEIRA, S. M. F. (Im)previdência Social: 60 anos de história da previdência social no Brasil. Petrópolis, Rio de Janeiro: Vozes, Abrasco, 1986.

SANTOS, M. A. B. \& GERSCHMAN, S. O Sistema Único de Saúde como desdobramento das políticas de saúde do século XX. Revista Brasileira de Ciências Sociais, 21: 177-190, 2006.

TEIXEIRA, S. M. F. Reforma Sanitária: em busca de uma teoria. Rio de Janeiro: Abrasco, 1989.

\section{ENTREVISTAS}

G. S. Entrevista realizada em 4 de maio de 2006. Rio de Janeiro. Transcrita. Arquivos GPPS/UFRGS.

J. R. Entrevista realizada em 31 de maio de 2006. Brasília. Transcrita. Arquivos GPPS/UFRGS.

K. L. Entrevista realizada em 13 de junho de 2006. Porto Alegre. Transcrita. Arquivos GPPS/UFRGS.

L. M. Entrevista realizada em 16 de janeiro de 2006. Porto Alegre. Transcrita. Arquivos GPPS/UFRGS.

M. C. Entrevista realizada em 23 de maio de 2006. Florianópolis. Transcrita. Arquivos GPPS/UFRGS.

N. G. Entrevista realizada em 31 de maio de 2006. Brasília. Transcrita. Arquivos GPPS/UFRGS.

P. G. Entrevista realizada em 31 de maio de 2006. Brasília. Transcrita. Arquivos GPPS/UFRGS.

Q. F. Entrevista realizada em 2 de junho de 2006. Brasília. Transcrita. Arquivos GPPS/UFRGS.

V. N. Entrevista realizada em $1^{\circ}$ de setembro de 2006. Florianópolis. Transcrita. Arquivos GPPS/UFRGS.

W. J. Entrevista realizada em 20 de setembro de 2006. Florianópolis. Transcrita. Arquivos GPPS/UFRGS. 



\title{
ASASELAÇẼES

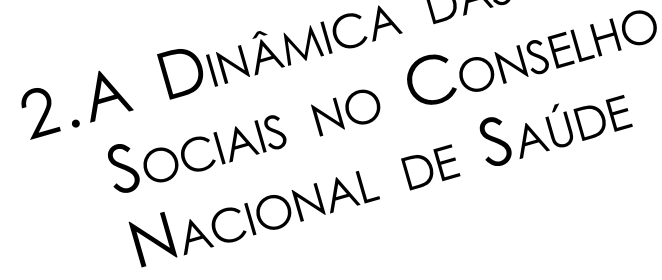

Marcelo Kunrath Silva

Soraya Vargas Côrtes

Janete Cardoso Réos

Márcio Barcelos

\begin{abstract}
Ao examinar a dinâmica das relações sociais no Conselho Nacional de Saúde (CNS), este capítulo tem dois objetivos. Em primeiro lugar, o funcionamento do fórum é analisado focalizando a intervenção dos diferentes atores e a dinâmica das discussões nas reuniões plenárias. Em segundo lugar, busca-se evidenciar que o padrão de funcionamento observado pode ser explicado pela configuração das relações estabelecidas entre os diversos atores envolvidos nas atividades do Conselho e, também, pela posição ocupada pelo fórum na arena decisória da área. Sabe-se que o desenho institucional do sistema de saúde constituído na década de 1990 estabeleceu os condicionantes fundamentais do funcionamento dos mecanismos participativos do Sistema Único de Saúde (SUS). No entanto, pretende-se aqui demonstrar que esse funcionamento pode ser interpretado de maneira mais adequada quando são incorporadas à análise as relações entre os atores no interior do Conselho e a posição do fórum no contexto da política de saúde nacional.

Como as reuniões examinadas ocorreram em 2005, para facilitar o entendimento do padrão de funcionamento do fórum são descritas, inicialmente, as instâncias, a estrutura de apoio administrativo e a dinâmica das reuniões plenárias, conforme elas se apresentavam naquele ano. A seguir, são caracterizadas a atuação dos membros do Conselho e as discussões que ocorriam durante as reuniões plenárias, procurando identificar os tipos de atores mais freqüentemente envolvidos nos debates, nas atividades de coordenação
\end{abstract}


e na representação do fórum em eventos e em outros fóruns e instituições. No final, são analisados as relações entre os atores no interior do Conselho e o papel que o fórum exercia no contexto da política de saúde nacional.

Os tipos de participantes envolvidos nas atividades do Conselho e na arena política da área da saúde são classificados como governamentais, sociais e de mercado. Tal classificação é feita porque se considera, assim como Cohen (2003), que uma grande separação entre atores estatais e societais não seria suficiente para expressar as diferenças que existem entre a sociedade civil, o Estado e o mercado, bem como entre os modos de ação e as motivações que os atores envolvidos nos processos sociais de cada uma dessas esferas têm para agir. $O$ capítulo examina também a atuação de comunidades de política (policy communities) no Conselho e na rede da política de saúde (policy network). Trata-se de um tipo de ator cuja formação e esfera de ação atravessam as fronteiras entre Estado e sociedade (Jordan \& Richardson, 1979; Rodes, 1986).

Para caracterizar a estrutura administrativa do Conselho e a dinâmica de funcionamento das reuniões, foram analisadas atas de 11 reuniões realizadas em 2005 e entrevistas com conselheiros. ${ }^{1}$ Também foram utilizadas informações disponíveis nos endereços eletrônicos do Conselho e do Ministério da Saúde, a legislação pertinente, portarias ministeriais, resoluções do próprio fórum, documentos obtidos no Conselho e diários de campo de observações das reuniões plenárias. ${ }^{2}$

${ }^{1}$ Foram analisadas 11 atas, embora tenha havido 12 reuniões plenárias em 2005, porque a ata da 153a reunião - de 12 , 13 e 14 de abril de 2005 - estava disponível somente no formato de resumo executivo. Examinaram-se as seguintes atas: 150a, de 11, 12 e 13/1/2005; 151a, de 15, 16 e $17 /$ 2/2005; 152a, de 8,9 e 10/3/2005; 154a de 4 e 5/5/2005; 155a , de 8 e 9/6/2005; 156a , de 13 e 14/7/2005; 157a de 10 e 11/8/2005; 158a de 14 e 15/9/2005; 159a, de 18 , 19 e 20/10/2005; 160a de 8,9 e 10/11/2005; e 161a , de 14 e 15/12/2005. As atas encontram-se disponíveis no seguinte endereço eletrônico: 〈www.conselho.saude.gov.br〉. As entrevistas, em um total de 23, foram aplicadas entre abril e setembro de 2006. Foram entrevistados: 1) 13 conselheiros e exconselheiros que representavam organizações da sociedade civil - um de organização religiosa; dois de entidades de trabalhadores, não especificamente da área da saúde; quatro de entidades de profissionais e trabalhadores de saúde; seis de entidades étnicas, de gênero e de portadores de patologias ou deficiências; 2) dois conselheiros e ex-conselheiros que representavam entidades de mercado - os dois de entidades nacionais de prestadores de serviços de saúde; e 3) oito conselheiros e ex-conselheiros que representavam órgãos governamentais - três de instituições não vinculadas à área da saúde e cinco de gestores de saúde (dois da esfera federal, um da estadual e dois da municipal).

${ }^{2}$ As observações foram realizadas durante quatro reuniões plenárias do Conselho: 159a reunião, em 18, 19 e 20/10/2005; 160a reunião, em 8, 9 e 10/11/2005; 161 a reunião, em 14 e 15/12/ 2005; 164a reunião, em 4, 5 e 6/4/2006. 
Este capítulo descreve, inicialmente, a estrutura administrativa do Conselho. A seguir, analisa a atuação dos conselheiros no interior do fórum e, logo após, a dinâmica das discussões durante as reuniões plenárias. No final, examina a configuração das relações sociais estruturada no Conselho e o papel do Conselho na configuração dessas relações na arena decisória da área da saúde.

\section{Conselho Nacional de SAÚde: estrutura ADMINISTRATIVA}

Em 2005, o Conselho era composto por cinco instâncias em torno das quais se organizava seu funcionamento cotidiano e suas reuniões plenárias: o plenário, as comissões, os grupos de trabalho, a Secretaria Executiva e a comissão de coordenação geral. A mais importante era o plenário, integrado por quarenta membros titulares, cada um com dois suplentes. $\mathrm{O}$ plenário era a instância de deliberação do Conselho. Reunia-se em reuniões ordinárias e extraordinárias em que eram apresentadas propostas de ações e políticas de saúde e discutidos temas diversos sobre os quais o plenário deliberava, votava e produzia resoluções.

A lei n. 8.080 (Brasil, 1990, art. 13) criou seis comissões intersetoriais permanentes no âmbito do Conselho, ${ }^{3}$ compostas pelos conselheiros indicados pelo plenário. Sua finalidade era a articulação de políticas e programas de interesse da saúde. Desde então, o próprio Conselho criou mais dez comissões permanentes. ${ }^{4}$ Tanto as comissões criadas pela lei n. 8.080 quanto as demais tinham natureza consultiva e de assessoramento para a tomada de decisões. Elas eram coordenadas por um conselheiro indicado pelo plenário e por um coordenador adjunto escolhido pelos membros da própria comissão. Existia ainda a possibilidade de criação de comissões transitórias.

Os grupos de trabalho também eram instituídos pelo plenário (Brasil, 1999). Os membros - no máximo cinco - não eram necessariamente conse-

\footnotetext{
${ }^{3}$ As comissões intersetoriais, compostas por até nove conselheiros, eram as seguintes: alimentação e nutrição; saneamento e meio ambiente; vigilância sanitária e farmacoepidemiologia; recursos humanos; ciência e tecnologia; e saúde do trabalhador.

${ }^{4}$ As comissões permanentes, não previstas na lei n. 8.080, foram criadas quando dois terços do plenário concordaram com sua constituição. Quando não tinham caráter intersetorial, eram compostas por até sete conselheiros. As comissões criadas foram as seguintes: saúde mental; saúde indigena; ética em pesquisa; orçamento e financiamento; redução da morbimortalidade por trauma e violência; saúde suplementar; eliminação da hanseníase; pessoas portadoras de patologias e deficiências; saúde da mulher; comunicação e informação.
} 
lheiros. Sua finalidade era fornecer subsídios de ordem técnica, administrativa, econômica, financeira e jurídica. Os grupos de trabalho eram transitórios, com vigência predeterminada.

A Secretaria Executiva era diretamente subordinada ao presidente do Conselho e funcionalmente vinculada ao gabinete do ministro da Saúde (Brasil, 1999). Sua função era oferecer apoio técnico-administrativo ao fórum, suas comissões e grupos de trabalho. O coordenador da Secretaria poderia ser substituído caso o plenário julgasse sua atuação inadequada ou inoperante. Em 2005, a Secretaria Executiva era composta por 34 trabalhadores: 17 de nível superior - quatro deles da área da saúde e 13 da área das humanidades - e 17 de nível médio (Magni, 2005).

Existia ainda a comissão de coordenação geral, com a finalidade de acompanhar as atividades da Secretaria Executiva (Brasil, 1999). Ela era composta por três conselheiros indicados pelo plenário. Essa comissão era também responsável pela organização das pautas de reuniões plenárias. Em geral, o coordenador da Secretaria Executiva participava das reuniões da comissão (I. E., entrevista, 23/5/2006). Observou-se que, ao longo de 2005, a comissão de coordenação geral foi composta exclusivamente por representantes de entidades sociais (I. E., entrevista, 23/5/2006).

Outra instância do Conselho era a Mesa Nacional de Negociações do SUS. Criada em 1993 (Brasil, 1993), teve funcionamento irregular até 1997, quando foi reinstalada (Brasil, 1997). Novamente suas atividades não tiveram continuidade. Por fim, foi reativada em 2003 (Brasil, 2003a) e esteve em funcionamento desde então, realizando reuniões ordinárias mensais e extraordinárias. A Mesa era um espaço de negociação permanente, envolvendo gestores federal, estaduais e municipais, entidades dos empregadores privados e entidades dos trabalhadores do SUS. Seu principal objetivo era ajudar a dirimir os conflitos resultantes das relações de trabalho.

O Conselho localizava-se no primeiro andar do Anexo B do Ministério da Saúde. Desde 2004, ele estava instalado em uma área física de aproximadamente trezentos metros quadrados, que comportava uma sala para a realização das reuniões plenárias, com capacidade para aproximadamente cem pessoas, e 11 salas para diferentes atividades complementares. ${ }^{5}$

${ }^{5}$ Em 2005, para o apoio das atividades do Conselho, havia: vinte computadores, todos com acesso à Internet; oito impressoras; uma máquina copiadora; dois aparelhos de fax; uma linha telefônica direta e 14 ramais; vários aparelhos audiovisuais, como projetor multimídia, aparelhagem de gravação, filmadora e câmera digital. 
As reuniões plenárias do Conselho eram mensais, ocorrendo em dias consecutivos. Em geral duravam dois dias, nos turnos da manhã e da tarde, mas dependendo da urgência para debater e votar determinados assuntos, a reunião poderia se estender por um terceiro dia. ${ }^{6}$ Os conselheiros sentavam-se a uma grande mesa em forma de 'U'. Seus lugares estavam identificados sobre a mesa. Convidados e observadores sentavam-se em cadeiras localizadas junto às paredes da sala.

No início de cada reunião, um funcionário solicitava a assinatura de todos os participantes em um livro de presenças. A coordenadora da Secretaria Executiva abria os trabalhos e instava os conselheiros a escolherem os integrantes da mesa coordenadora para cada ponto de pauta. Em geral, eram indicados pela plenária os conselheiros que apresentassem maior familiaridade ou envolvimento com cada um dos assuntos que constavam da pauta. Essa dinâmica inicial das reuniões plenárias sofria alterações quando o ministro da Saúde comparecia à reunião. Nessas ocasiões, ele falava em primeiro lugar. Normalmente, uma vez definidos os integrantes da mesa para cada ponto de pauta, passava-se aos informes gerais. Eram relatos de conselheiros que haviam representado o Conselho em eventos, e relatos das comissões e dos grupos de trabalho, ou ainda apresentações de denúncias e relatos e solicitações de inclusão de assuntos na pauta. A seguir, a primeira mesa coordenadora era composta e passava-se para o primeiro assunto da pauta, e assim sucessivamente.

Era a comissão de coordenação geral que elaborava a pauta de cada reunião, a qual era enviada por meio eletrônico ou correio convencional, com antecedência de 15 dias, aos conselheiros titulares e suplentes (N. G., entrevista, 31/5/2006). Contudo, existia a possibilidade de mudança de pauta, por solicitação de conselheiro, no início da reunião, durante os informes gerais, desde que a maioria do plenário concordasse.

Em razão da existência de um acúmulo de pontos de pauta a serem objeto de deliberação nas reuniões plenárias, havia uma tentativa de organização da agenda de discussões, com base em temas nos quais eram reunidos os assuntos similares cuja inserção na pauta havia sido demandada previamente pelos conselheiros. A definição da pauta se produzia, assim, no cruzamento entre essa agenda de temas definida pelo Conselho e as questões emergenciais impostas pela conjuntura ou por atores externos ao fórum.

\footnotetext{
${ }^{6}$ As reuniões ocorriam na sala de reunião, denominada Sala Omilton Visconde Júnior, em homenagem a um ex-conselheiro, falecido em 1996, representante da indústria farmacêutica.
} 
Muitos assuntos que integravam a pauta passavam por discussão prévia nas comissões ou nos grupos de trabalho, por serem considerados temas técnicos que necessitavam de esclarecimentos adicionais antes de serem apreciados pelo plenário. Nesses casos, no início da discussão de um ponto de pauta específico, as comissões ou os grupos de trabalho apresentavam os resultados de seu trabalho e respondiam a questões. Quando os conselheiros julgavam necessário, eram convidados especialistas para participar das reuniões das comissões, dos grupos de trabalho ou da plenária (Magni, 2005; J. R., entrevista, 31/5/2006). Uma vez apresentado o assunto, iniciavam-se os debates e eram feitas propostas de encaminhamento, que a seguir eram votadas, quando não havia consenso. Em alguns casos, o assunto era tão polêmico que a interrupção da reunião era solicitada por conselheiros (Magni, 2005; A. H., entrevista, 11/4/2006; K. L., entrevista, 13/6/2006). Isso ocorria para que houvesse discussão intra-segmento - usuários, trabalhadores de saúde, gestores ou prestadores - ou consulta às entidades representadas. Era possível, ainda, que um conselheiro pedisse vistas de determinado projeto, interrompendo assim o debate do assunto em questão.

A reunião encerrava-se quando todos os pontos de pauta tivessem sido abordados ou quando acabava o tempo da reunião, sem que todas as discussões previstas houvessem se realizado, o que ocorria freqüentemente. Ao perceber, a certa altura da reunião, que não haveria tempo para discutir todos os pontos agendados, a coordenação da Secretaria Executiva propunha ao plenário a priorização de alguns assuntos. Uma vez selecionados os assuntos que ainda seriam discutidos naquela reunião, os pontos de pauta restantes eram reagendados (Q. F., entrevista, 2/6/2006).

\section{A Atuação dos ConselHeiros: PREdomínio dos REPRESENTANTES DE ENTIDADES SOCIAIS E A CONSTITUIÇÃO DE UMA NOVA COMUNIDADE DE POLÍTICA}

Em 2005, de acordo com as normas legais, predominavam na composição do Conselho representantes de entidades da sociedade civil $(67 \%$ 27 em quarenta), distribuídas nas categorias: organizações de profissionais e trabalhadores de saúde; de trabalhadores, não especificamente da área da saúde; associações comunitárias e movimentos sociais; entidades étnicas, de gênero e de portadores de patologias ou deficiências; igrejas (Tabela 1). Em segundo lugar, com $20 \%$ das vagas (oito em quarenta), estavam os re- 
presentantes de órgãos governamentais: seis do governo federal (dentre eles o ministro da Saúde, então presidente do Conselho); um dos gestores estaduais (Conselho Nacional de Secretários de Saúde - Conass); e um dos gestores municipais (Conselho Nacional de Secretários Municipais de Saúde - Conasems). Por fim, com pouco mais de 12\% das vagas (cinco em quarenta), apareciam os representantes de entidades de mercado: oriundos de duas entidades de prestadores privados de serviços de saúde e de duas organizações empresariais (Confederações Nacionais da Indústria - CNI - e do Comércio - CNC).

Tabela 1 - Número e percentual de conselheiros, de acordo com as normas legais, segundo os tipos de representantes: sociais, governamentais e de mercado. Conselho Nacional de Saúde (CNS) - 2005

\begin{tabular}{l|c|c}
\hline \multirow{2}{*}{ Tipos de representantes } & \multicolumn{2}{|c}{2005} \\
\cline { 2 - 3 } & Número & Percentual \\
\hline Sociais & 27 & 67,5 \\
Governamentais & 8 & 20,0 \\
De mercado & 5 & 12,5 \\
\hline \multirow{2}{*}{ Total } & 40 & 100 \\
\hline
\end{tabular}

Fonte: Brasil, 2003b.

As atas das 11 reuniões plenárias analisadas registraram a presença de 94 conselheiros, entre titulares e suplentes. ${ }^{7}$ A freqüência desses conselheiros foi bastante desigual. Houve aqueles que estiveram presentes a apenas uma reunião - e, em alguns casos, a apenas um dia de reunião -, enquanto outros compareceram a todas as reuniões, com apenas um caso de presença em todos os 27 dias de reunião examinados. ${ }^{8}$

Constatou-se que os 94 presentes às reuniões estavam distribuídos por tipos de participantes da maneira apresentada no Gráfico 1. A maioria deles - quase três quartos - representava entidades sociais (68 em 94). A seguir vinham os conselheiros provenientes de órgãos governamentais, com menos de um quinto dos presentes (17 em 94), enquanto os representantes de

\footnotetext{
${ }^{7}$ Não foram contabilizadas a presença ou manifestações do ministro da Saúde (Humberto Costa e Saraiva Felipe), porque sua atuação no Conselho como dirigente maior do Ministério da Saúde e presidente do fórum o colocava em uma posição diferenciada em relação aos demais conselheiros.

${ }^{8}$ As reuniões plenárias ordinárias do Conselho, como era o caso daquelas analisadas, tiveram a duração de dois e três dias, em 2005. As 11 reuniões cujas atas foram analisadas referiram-se, assim, a 27 dias de reunião.
} 
entidades de mercado não chegavam a perfazer um décimo daqueles que compareceram às reuniões (oito em 94).

Os dados do Gráfico 1, quando comparados com a distribuição das vagas estabelecida pelas normas legais apresentada na Tabela 1, indicam que a proporção de conselheiros oriundos de organizações sociais presentes às reuniões era um pouco maior do que a prevista legalmente. Enquanto a legislação estabelecia em 67\% (27 em quarenta) a proporção de conselheiros provenientes de organizações sociais em relação ao total de membros do Conselho, os representantes dessas organizações que efetivamente compareceram às 11 reuniões analisadas corresponderam a 73\% do total de presentes (68 em 94). Em decorrência, o número de representantes governamentais e de entidades de mercado que compareceram às 11 reuniões foi menor do que o previsto: $18 \%$ e $8 \%$ (17 e oito em 94), respectivamente, quando as normas legais previam 20\% e 12\% (oito e cinco em quarenta), respectivamente. Se, por um lado, o número maior de representantes de organizações sociais se deve à maior rotatividade entre conselheiros titulares e suplentes nesse tipo de participantes; por outro, reflete também sua maior assiduidade às reuniões.

Gráfico 1 - Número e percentual de conselheiros presentes às reuniões plenárias, por tipo de participantes: sociais, governamentais e de mercado. Conselho Nacional de Saúde (CNS) - 2005

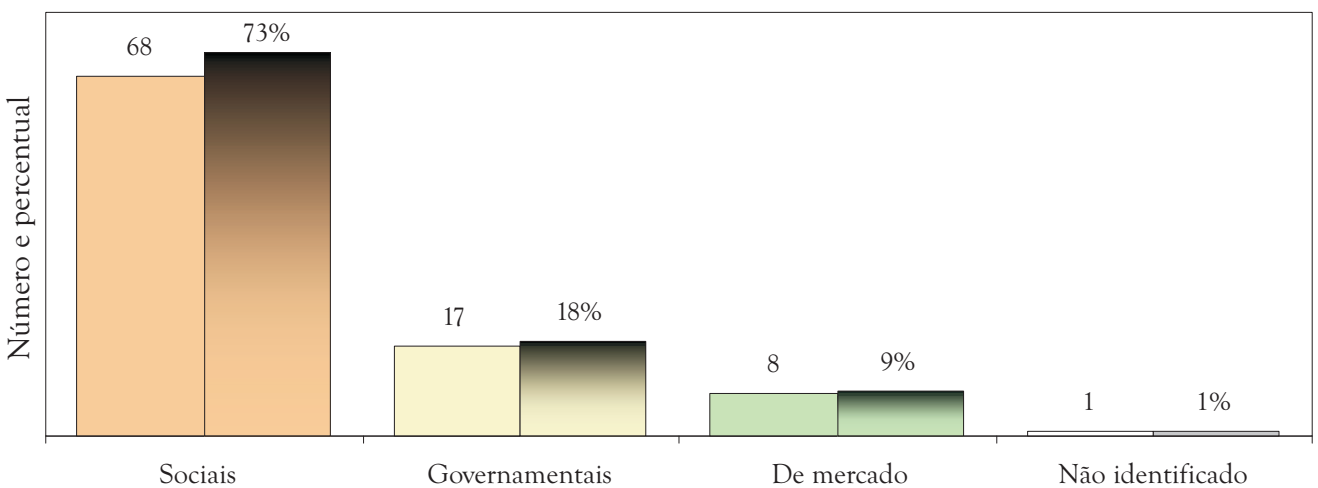

Tipo de participantes

Fonte: Brasil, 2005. 
A Tabela 2 apresenta a relação entre quatro faixas de número de reuniões a que cada um dos conselheiros presentes às 11 reuniões compareceu - uma a três, quatro a seis, sete a nove, e dez a 11 - e tipos de participantes. Em primeiro lugar, constata-se que os representantes de entidades de mercado, além de serem poucos - apenas oito conselheiros se fizeram presentes às reuniões -, não eram assíduos. Apenas três deles compareceram a mais da metade das reuniões realizadas. Isso pode significar que tal tipo de conselheiro representante de prestadores de serviços de saúde e de entidades empresariais - não identificava o Conselho como espaço prioritário de intervenção.

Tabela 2 - Número e percentual de conselheiros, por número de reuniões a que compareceram, segundo os tipos de conselheiros: sociais, governamentais e de mercado. Conselho Nacional de Saúde (CNS) - 2005

\begin{tabular}{|c|c|c|c|c|c|c|c|}
\hline \multicolumn{2}{|c|}{$\begin{array}{l}\text { Número de reuniões } \\
\text { Tipos de participantes }\end{array}$} & 1 a 3 & 4 a 6 & 7 a 9 & 10 a 11 & $\begin{array}{c}\text { Não } \\
\text { identificado }\end{array}$ & Total \\
\hline \multirow{2}{*}{ Não identificado } & Número & 1 & - & - & - & - & 1 \\
\hline & $\%$ & $2 \%$ & - & - & - & - & $1 \%$ \\
\hline \multirow{2}{*}{ De mercado } & Número & 5 & - & 1 & 2 & - & 8 \\
\hline & $\%$ & $12 \%$ & 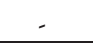 & $4 \%$ & $18 \%$ & - & $9 \%$ \\
\hline \multirow{2}{*}{ Governamentais } & Número & 10 & 3 & 3 & 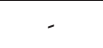 & 1 & 17 \\
\hline & $\%$ & $24 \%$ & $20 \%$ & $12 \%$ & - & $100 \%$ & $18 \%$ \\
\hline \multirow{2}{*}{ Sociais } & Número & 26 & 12 & 21 & 9 & 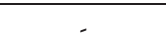 & 68 \\
\hline & $\%$ & $62 \%$ & $80 \%$ & $84 \%$ & $82 \%$ & - & $72 \%$ \\
\hline \multirow{2}{*}{ Total } & Número & 42 & 15 & 25 & 11 & 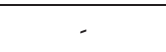 & 94 \\
\hline & $\%$ & $100 \%$ & $100 \%$ & $100 \%$ & $100 \%$ & $100 \%$ & $72 \%$ \\
\hline
\end{tabular}

Fonte: Brasil, 2005.

Em segundo lugar, observa-se que a maior parte dos presentes que representavam órgãos governamentais esteve presente a poucas reuniões: quase três quintos deles (59\% - dez em 17) compareceram a apenas uma, duas ou três das 11 reuniões examinadas. Ou seja, houve, no período, significativa rotatividade entre os representantes governamentais que freqüentavam as reuniões plenárias do fórum. Uma das razões pode ter sido a troca de ministro da Saúde, em julho de 2005. Embora a mesma coalizão política permanecesse no governo federal, Humberto Costa, do Partido dos Trabalhadores (PT), foi substituído no comando do Ministério por Saraiva Felipe, do Partido do Movimento Democrático Brasileiro (PMDB). Em conseqüência, 
foi alterada a equipe diretiva do Ministério. Como as pessoas nesses cargos eram as que mais compareciam às reuniões, representando o Ministério da Saúde e ocupando as três das oito vagas disponíveis para o Ministério no Conselho, esta pode ser uma das razões para a rotatividade verificada entre esses conselheiros.

Por fim, contrastando com os demais tipos de participantes, os conselheiros provenientes de organizações sociais eram os mais assíduos às reuniões. Dentre os 11 conselheiros que compareceram a dez ou 11 reuniões e dentre os 25 que estiveram presentes em sete a nove reuniões das 11 examinadas, nove $(82 \%)$ e $21(84 \%)$, respectivamente, eram representantes de entidades da sociedade civil. Esta é uma indicação adicional de sua importância nas atividades do Conselho, uma vez que, além de legalmente terem a maior proporção de votos no fórum, eles eram os mais assíduos.

Se a presença é uma condição necessária para que haja participação e para que se exerça influência nas discussões e deliberações do Conselho, um importante indicador do exercício efetivo de influência é a intervenção dos conselheiros nas reuniões. Nas atas das 11 reuniões plenárias examinadas, foram identificadas referências a intervenções de 78 dos 94 conselheiros cujas presenças foram registradas. Ou seja, 17\% daqueles que estiveram presentes (16 em 94) às reuniões não tiveram nenhum tipo de intervenção registrada nas atas, indicando a ocupação de uma posição periférica no processo decisório que ocorria no Conselho.

A Tabela 3 mostra o número de intervenções dos 78 conselheiros que se manifestaram verbalmente durante as reuniões analisadas, distribuídas pelos tipos de participantes. Observa-se que a maior parte das intervenções foi feita por representantes de entidades sociais. Dentre os 13 conselheiros que se manifestaram mais de cinqüenta vezes nas reuniões, 11 eram provenientes de organizações sociais, e estes, sozinhos, foram responsáveis por 59\% das intervenções registradas nas atas (1.021 em 1.732). Os outros dois conselheiros que se destacaram, em termos do número de intervenções, eram representantes governamentais. Por fim, observa-se que os conselheiros provenientes de entidades de mercado, além de não comparecerem muito às reuniões, tinham pequena participação nos debates. 
Tabela 3 - Número de intervenções por tipos de conselheiros: sociais, governamentais e de mercado. Conselho Nacional de Saúde (CNS) - 2005

\begin{tabular}{|c|c|c|c|c|c|}
\hline \multirow{2}{*}{$\begin{array}{c}\text { Número de } \\
\text { intervenções }\end{array}$} & \multicolumn{5}{|c|}{ Tipos de participantes } \\
\hline & $\begin{array}{c}\text { Não } \\
\text { identificado }\end{array}$ & $\begin{array}{c}\text { De } \\
\text { mercado }\end{array}$ & Governamentais & Sociais & Total \\
\hline 0 & - & 3 & 4 & 9 & 16 \\
\hline 1 a 10 & 1 & 3 & 8 & 23 & 35 \\
\hline 11 a 20 & - & - & 1 & 16 & 17 \\
\hline 21 a 30 & - & 2 & 2 & 5 & 9 \\
\hline 31 a 40 & - & - & - & 3 & 3 \\
\hline 41 a 50 & - & - & - & 1 & 1 \\
\hline SUBTOTAL O a 50 & 1 & 8 & 15 & 57 & 81 \\
\hline 51 a 60 & - & - & 1 & 2 & 3 \\
\hline 61 a 70 & - & - & 1 & - & 1 \\
\hline 71 a 80 & - & - & - & 3 & 3 \\
\hline 81 a 90 & - & - & - & - & - \\
\hline 91 a 100 & - & - & - & 1 & 1 \\
\hline 101 a 110 & - & - & - & 2 & 2 \\
\hline 111 a 120 & - & - & - & 1 & 1 \\
\hline 121 a 130 & - & - & - & - & - \\
\hline 131 a 140 & - & - & - & - & - \\
\hline 141 a 150 & - & - & - & - & - \\
\hline 151 a 160 & - & - & - & 1 & 1 \\
\hline 161 a 170 & - & - & - & - & - \\
\hline 171 a 180 & - & - & - & 1 & 1 \\
\hline $\begin{array}{l}\text { SUBTOTAL } \\
51 \text { a } 180\end{array}$ & - & - & 2 & 11 & 13 \\
\hline Total & 1 & 8 & 17 & 68 & 94 \\
\hline
\end{tabular}

Fonte: Brasil, 2005.

Uma vez constatado que os representantes de entidades sociais eram os mais assíduos às reuniões e os que mais se envolviam nos debates, buscouse verificar quais eram as categorias de conselheiros provenientes de organizações sociais mais atuantes. Aqueles que ocupavam as posições de maior destaque em termos do número de intervenções eram três representantes de associações comunitárias e movimentos sociais, três de entidades étnicas, de gênero e de portadores de patologias ou deficiências e, em maior 
número, cinco conselheiros provenientes de organizações de profissionais e trabalhadores de saúde. Neste último subgrupo se situam dois participantes que, sozinhos, foram responsáveis por quase 20\% do total de intervenções registradas nas atas (319 em 1.732). Constatou-se ainda que os representantes de trabalhadores, não especificamente da área da saúde - Central Única dos Trabalhadores (CUT), Força Sindical, Confederação Nacional dos Trabalhadores na Agricultura (Contag) -, tiveram uma participação muito reduzida nos debates.

Outro indicador utilizado, para aprofundar o exame sobre o nível de participação e influência dos conselheiros sobre as atividades do Conselho, foi a atividade de coordenação de pontos de pauta durante as reuniões plenárias. Constatou-se que apenas 30\% (28) dos 94 conselheiros presentes às reuniões assumiram coordenações de discussões durante as reuniões analisadas. Assim, percebe-se a existência de assimetria também na distribuição dessa função entre os conselheiros. A Tabela 4 mostra uma preponderância dos conselheiros oriundos de entidades sociais, que responderam por $82 \%$ das coordenações das discussões nas reuniões do Conselho (23 em 28). Entre os dez conselheiros que mais coordenaram reuniões plenárias - com três ou mais coordenações -, nove representavam organizações sociais e apenas um os órgãos de governo.

Tabela 4 - Freqüência de coordenações - número e percentual - por tipos de conselheiros: sociais, governamentais e de mercado. Conselho Nacional de Saúde (CNS) - 2005

\begin{tabular}{c|cc|cc|cc|cc}
\hline \multirow{2}{*}{$\begin{array}{c}\text { Número de reuniões } \\
\text { em que cada conselheiro } \\
\text { assumiu a coordenação }\end{array}$} & \multicolumn{2}{|c|}{ De mercado } & \multicolumn{2}{c|}{ Governamentais } & \multicolumn{2}{c|}{ Sociais } & \multicolumn{3}{c}{ Total } \\
\hline 1 & 2 & 14,3 & 2 & 14,3 & 10 & 71,4 & 14 & 100 \\
2 & - & - & - & - & 4 & 100 & 4 & 100 \\
3 & - & - & 1 & 25 & 3 & 75 & 4 & 100 \\
4 & - & - & - & - & 4 & 100 & 4 & 100 \\
5 & - & - & - & - & 1 & 100 & 1 & 100 \\
7 & 2 & 7 & 3 & 11 & 23 & 82 & 28 & 100 \\
\hline \multirow{2}{*}{ Total } & & - & - & - & 1 & 100 & 1 & 100 \\
\hline
\end{tabular}

Fonte: Brasil, 2005. 
Um último aspecto para caracterizar a atuação dos conselheiros referese às atividades de representação externas ao Conselho. Existia um intenso processo de participação de conselheiros em eventos e fóruns, tais como seminários, congressos, conferências e outros conselhos. Tal participação, em geral, era provocada por convite solicitando a indicação de um representante do fórum. Essa representação externa, em geral custeada com recursos do Conselho, era vista como fundamental tanto para a divulgação das posições dominantes no âmbito do fórum, quanto para a constituição e o fortalecimento dos laços entre atores aliados na rede política da área.

A Tabela 5 mostra que a distribuição das representações também é assimétrica: dos 94 conselheiros presentes às reuniões analisadas, 45 (48\%) exerceram funções de representação. Quando comparado ao número de conselheiros que coordenaram pontos de pauta nas reuniões - 28 (30\%) percebe-se que houve uma distribuição mais homogênea de oportunidades de representar externamente o fórum do que de coordenar suas reuniões. A Tabela 5 mostra ainda que, dentre os 45 conselheiros que exerceram funções de representação externa do Conselho, 41 (91\%) eram provenientes de organizações da sociedade civil. Portanto, tais funções eram ainda mais concentradas nesse tipo de conselheiro (41 em 45,91\%) do que a atividade de coordenação de pontos de pauta de reuniões (23 em 28,82\%).

Tabela 5 - Freqüência de representações externas ao Conselho (número e percentual) por tipos de conselheiros: sociais, governamentais e de mercado. Conselho Nacional de Saúde (CNS) - 2005

\begin{tabular}{c|cc|cc|cc|cc}
\hline \multirow{2}{*}{$\begin{array}{c}\text { Número de vezes em que } \\
\text { representou o Conselho } \\
\text { externamente }\end{array}$} & \multicolumn{2}{|c|}{ De mercado } & \multicolumn{2}{|c|}{ Governamentais } & \multicolumn{2}{|c}{ Sociais } & \multicolumn{2}{|c}{ Total } \\
\cline { 2 - 8 } & Número $\%$ & Número & $\%$ & Número & $\%$ & Número & $\%$ \\
2 & 1 & 5 & 1 & 5 & 17 & 90 & 19 & 100 \\
3 & - & - & - & - & 10 & 100 & 10 & 100 \\
4 & - & - & - & - & 5 & 100 & 5 & 100 \\
5 & - & - & - & - & 1 & 100 & 1 & 100 \\
6 & - & - & 1 & 25 & 3 & 75 & 4 & 100 \\
7 & - & - & - & - & 1 & 100 & 1 & 100 \\
9 & - & - & - & - & 2 & 100 & 2 & 100 \\
15 & - & - & 1 & 50 & 1 & 50 & 2 & 100 \\
\hline Total & - & - & - & - & 1 & 10 & 1 & 100 \\
\hline
\end{tabular}

Fonte: Brasil, 2005. 
Assim, a análise dos indicadores de presença às reuniões, freqüência de intervenções, coordenação de pontos de pauta e representação do Conselho em atividades externas permitiu constatar que havia no Conselho o predomínio dos conselheiros provenientes de organizações sociais. Dentre estes, destacavam-se os representantes de associações comunitárias e movimentos sociais, de entidades étnicas, de gênero e de portadores de patologias ou deficiências e, especialmente, de organizações de profissionais e trabalhadores de saúde. É inegável que havia uma preponderância relativa desses conselheiros na condução das discussões e deliberações, ante a menor participação de conselheiros governamentais e o quase nulo envolvimento de representantes de entidades de mercado. Os representantes de órgãos governamentais, no entanto, por sua centralidade na definição e na implantação da política de saúde, certamente exerciam influência superior àquela que sua presença nas reuniões e o número de intervenções, de coordenações de pontos de pauta e de representações externas ao Conselho poderiam indicar. Além disso, especialmente os gestores federais de saúde constituíram-se nos principais interlocutores e alvo de grande parte das intervenções dos representantes de entidades sociais.

Foi possível, ainda, identificar a existência de um 'núcleo duro' de conselheiros que respondia por grande parte da dinâmica das reuniões. Tomando o conjunto de indicadores utilizados, nota-se um pequeno grupo de seis conselheiros que, além de serem muito presentes às reuniões, respondiam por: $33 \%$ do total de intervenções registradas nas atas analisadas (579 em 1.732); 35\% das coordenações (22 em 62) e 28\% das representações externas (37 em 131). Esses seis conselheiros representavam entidades sociais: quatro deles eram provenientes de organizações de profissionais e trabalhadores de saúde e dois de associações comunitárias e movimentos sociais.

Em torno desses conselheiros construíam-se estratégias de ação e estabeleciam-se consensos sobre posições a serem assumidas e propostas a serem defendidas no plenário - e fora dele - pela maioria dos conselheiros que representavam entidades da sociedade civil no Conselho. Esse núcleo e, especialmente, os quatro representantes de organizações de profissionais e trabalhadores de saúde que o integravam, os quais eram vinculados ao Fórum das Entidades Nacionais dos Trabalhadores da Área da Saúde (Fentas), articulavam no Conselho a constituição de uma nova comunidade de política na área da saúde. Embora tivessem ligações com a CUT e se mostras- 
sem até certo ponto favoráveis à coalizão governista, a relação que estabeleciam com o gestor federal de saúde era muitas vezes de disputa. O depoimento a seguir, de um deles, revela esse fato:

Quando a disputa está muito acirrada, quando é uma disputa pesada mesmo, a gente articula. Tenta convencer o outro. Porque assim nós não somos bobos. Nós entendemos que os gestores têm um grupo com quem eles já constroem suas pautas. E eu acho legítimo, como em qualquer lugar tem que fazer suas composições. Então a gente discute, muitas vezes não consegue, a maioria tem conseguido, mas muitas vezes a gente não consegue, não. O que o governo tem é mais convincente que a gente. (G. S., entrevista, 4/5/2006)

Esse núcleo defendia as diretrizes fundamentais do SUS, mas ressaltava que o sistema deveria expandir a provisão pública de serviços e garantir os interesses trabalhistas de categorias de profissionais e de trabalhadores não médicos. Ao mesmo tempo se opunha sistematicamente às entidades que defendiam os interesses da categoria médica, vistos como identificados com propostas liberais de organização do sistema de saúde. Segundo sua interpretação, o SUS continuava sendo um sistema 'privatizado' (Q. F., entrevista, 2/6/2006), pois os gastos com serviços de média e alta complexidades, cuja provisão era realizada por prestadores privados, eram muito superiores àqueles destinados à assistência básica, oferecida diretamente por provedores públicos.

Para mim, o SUS ainda continua privatizado, ainda continua nas mãos de grupos econômicos muito fortes, e mais ainda, de corporações. (...) Este processo de privatização, de dominio de corporações, (...) é o grande desafio do controle social. Primeiro é perceber a gravidade dessa situação, porque se você pega o orçamento do sistema, mais de 50\% é média e alta complexidade. O que é isso? Setor privado. (Q. F., entrevista, 2/6/2006)

Os gestores, profissionais de saúde e acadêmicos identificados com o 'movimento sanitário', que ocupavam cargos de direção no Ministério da Saúde, eram vistos por eles como acomodados à situação persistente, não defendendo a contento os princípios que levaram à criação do SUS. Os representantes de organizações sociais é que poderiam tentar modificar tal situação por meio do controle social.

No entanto, vários entrevistados, identificados com o movimento sanitário - que haviam participado da Reforma Sanitária e, em 2005, ocupavam cargos de gestão -, consideravam as disputas constantes no Conselho como um entrave à consolidação do fórum como arena decisória 
do sistema. Segundo eles, o Conselho perdia muito tempo e energia apurando denúncias e cobrando ações dos gestores, enquanto poderia estar formulando estratégias para um gerenciamento mais eficaz do sistema. Assim, o Conselho renunciava a um protagonismo que era assumido principalmente pelas comissões intergestores (A. H., entrevista, 11/4/2006; V. N., entrevista, 1\%/9/2006; W. J., entrevista, 20/9/2006).

$\mathrm{O}$ que era visto como problema para os integrantes do movimento sanitário era encarado como estratégia fundamental para a consolidação da capacidade de influenciar as políticas pela nova comunidade. Por meio do Conselho era possível demarcar posições e disputar interpretações sobre problemas e sobre propostas de soluções com outras comunidades de política, marcadamente com a antiga comunidade reformista, o movimento sanitário. Era possível ainda articular-se com os participantes dos conselhos estaduais e municipais de modo a fortalecer nacionalmente o apoio às suas posições. Por isso, as disputas com o Ministério da Saúde relacionadas ao controle sobre a gestão participativa no SUS foram tão freqüentes, e o ponto de pauta mais discutido no Conselho foi o funcionamento do próprio fórum e a participação em saúde no país.

\section{DinÂMICA das Discussões nas Reuniões PlenÁRIAs: FORMAÇÃO DA AGENDA, TEMAS EM DISCUSSÃO E TIPOS DE INTERVENÇÃO}

Para caracterizar a dinâmica das discussões nas reuniões plenárias, inicialmente procurou-se identificar como suas pautas eram formadas e quem as elaborava. Isto porque o controle da agenda de debates é um indicador importante da influência que os atores têm sobre um fórum ou arena política. As normas de funcionamento do fórum estabeleciam que a Comissão de Coordenação Geral (CCG), junto com a Secretaria Executiva, era responsável pela confecção da pauta antes do início das reuniões, mas, ao longo delas, novos assuntos poderiam ser incluídos em razão de demandas do Ministério da Saúde e dos conselheiros.

Os conselheiros entrevistados salientavam a forte presença da Secretaria Executiva na construção da pauta. Segundo eles, isso ocorria devido à vinculação funcional da Secretaria ao Ministério da Saúde e ao fato de ela dedicar-se exclusivamente à gestão das atividades administrativas do Conselho. Por essa razão, a Secretaria teria mais informações sobre o contexto da 
política de saúde e sobre as demandas de gestores e de outros conselheiros para a inclusão de determinados assuntos na agenda de debates (K. L., entrevista, 13/6/2006). No entanto, havia também a percepção de que, especialmente a partir da criação da CCG, em 2003, essa influência havia declinado e os conselheiros passaram a participar mais do processo de construção das pautas (H. A., entrevista, 5/5/2006; P. G., entrevista, 31/5/2006).

Embora fossem mencionados instituições ou atores externos ao Conselho, tais como o Legislativo, a imprensa ou outras instâncias do controle social (P. G., entrevista, 31/5/2006; Q. F., entrevista, 2/6/2006; V. N., entrevista, 1/9/2006), os entrevistados foram praticamente unânimes em afirmar que a pauta era fruto de uma negociação, na qual aqueles que mais influíam eram os representantes de entidades sociais e dos gestores de saúde, principalmente federais. A influência dos conselheiros que representavam organizações da sociedade civil era exercida fundamentalmente de três maneiras. Em primeiro lugar, eles estavam presentes na CCG, a qual, no período, era composta exclusivamente por conselheiros provenientes de organizações sociais. ${ }^{9}$ Em segundo, o plenário do Conselho - que apresentava preponderância de participação de representantes de entidades sociais, em termos de presença, assiduidade e coordenação de reuniões - também tinha grande influência na formação da pauta, constituindo-se assim como outro espaço em que intervinha para incluir temas de seu interesse na agenda de discussões. Por fim, havia entre eles atores com significativa capacidade de articulação e de proposição, o que lhes permitia desempenhar um papel ativo na construção das pautas do fórum. Esses conselheiros, identificados com as estratégias de ação e as propostas da nova comunidade de política em formação, agiam como seu 'núcleo especialista', definindo os assuntos e as posições a serem assumidas no debate público do Conselho e da área da saúde. $\mathrm{O}$ depoimento seguinte caracteriza a situação:

O nosso fórum [Fentas] tem sido um dos grandes alimentadores de assuntos para debate. Não vou dizer que é o que mais faz, nem também que o que traz tem mais importância do que os outros [trazem]. Mas é que o nosso fórum, talvez pela natureza dele de ser formado pelos profissionais (...). Nós temos, por conta disso, uma maior oportunidade de estar em contato com determinados assuntos. (N. G., entrevista, 31/5/2006)

\footnotetext{
${ }^{9}$ Em 2005, a CCG do Conselho era integrada por dois representantes de entidades étnicas, de gênero e de portadores de patologias ou deficiências e um de profissionais e trabalhadores de saúde.
} 
Debates prévios travados no 'fórum dos trabalhadores de saúde' do Conselho construíam consensos, muitas vezes com base em propostas desses conselheiros, os quais depois eram apresentados ao 'fórum dos usuários' para a elaboração de posições comuns (H. A., entrevista, 5/5/2006; M. C., entrevista, 23/5/2006). Como descreve um entrevistado: "Hoje, 25\% do Conselho estão na mão de um fórum, do Fentas. (...) Eles conseguem se reunir todo mês. E dizem o que os conselheiros vão falar ou não vão falar. (...) Então, tem um bloco fortíssimo dos trabalhadores de saúde" (H. A., entrevista, 5/5/2006).

Na definição da agenda de debates, existia um padrão similar ao observado em relação à participação de conselheiros nas reuniões plenárias. Os atores governamentais, especialmente de nível federal - Ministério da Saúde, outros ministérios, Congresso Nacional -, pela sua centralidade na formulação e execução da política de saúde, incidiam mais na definição da pauta. Sua capacidade de exercer influência independia da quantidade de seus representantes no plenário ou na CCG, ou de sua assiduidade às reuniões - o que é ilustrado claramente, e de forma crítica, no seguinte trecho de entrevista:

Eu acho que o Conselho ainda é muito pautado pelo Ministério da Saúde. O Conselho devia ter a sua pauta própria. E essa pauta própria ser administrada com a pauta do gestor. O que acontece é que a pauta do gestor passa a ser a pauta do Conselho. E as pautas propriamente ditas do Conselho, elas acabam não avançando em função do atropelamento da pauta do gestor. (R. C., entrevista, 11/7/2006)

A construção da agenda de debates do CNS era um processo protagonizado por diversos atores. Os gestores federais apresentavam uma posição preponderante, mas que não significava um monopólio na definição da agenda do fórum. Ao contrário, também apresentavam um importante papel nessa definição conselheiros provenientes de entidades sociais, dentre eles particularmente os representantes de organizações de profissionais e trabalhadores da saúde, vinculados ao Fentas, articulados a conselheiros oriundos de entidades étnicas, de gênero e de portadores de patologias ou deficiências.

Para caracterizar a dinâmica das reuniões plenárias do Conselho, além de se examinar como se formava a agenda de debates do fórum, foi utilizado outro indicador: os temas em pauta nas reuniões, identificando a fre- 
qüência com que cada tipo e cada categoria de participante intervinham no debate desses temas. Para isso foi elaborada uma classificação temática dos assuntos discutidos, com base em tipologia já desenvolvida para analisar atas de reuniões em conselhos municipais de Saúde (Côrtes, 1999), adaptada às especificidades dos assuntos em debate no CNS. A classificação resultante foi a seguinte:

- gestão em saúde: funcionamento e relação das instâncias de gestão em saúde, nos níveis federal, estadual e municipal;

- trabalhista/profissionais de saúde: relações e demandas trabalhistas no âmbito do SUS;

- funcionamento e papel do Conselho/controle social: estrutura, dinâmica e papel do fórum, além de suas relações com outras instâncias de deliberação e gestão da política de saúde;

- questões financeiras: financiamento da política de saúde, nos seus diversos aspectos, tais como recursos para a área da saúde, execução orçamentária, prestação de contas, distribuição dos recursos entre programas e ações, entre outros;

- organização dos serviços de saúde: organização e funcionamento dos serviços de saúde;

- políticas específicas e programas de saúde: propostas, avaliações e discussões de políticas específicas e programas de saúde;

- questões locais/particulares: assuntos pontuais ou particularizados.

Seis desses temas foram abordados nas 11 reuniões examinadas. A exceção foi a 'organização dos serviços de saúde', discutida em nove reuniões. No entanto, se a maior parte dos temas foi discutida em todas as reuniões, o mesmo não se pode afirmar sobre o tempo despendido para debater cada um deles ou sobre o envolvimento dos participantes nas discussões. Utilizou-se como indicador do tempo de debates o número de caracteres utilizados nas atas para relatar a discussão em torno de cada tema, porque elas registram as intervenções de forma bastante detalhada, sendo que, por vezes, foram feitas transcrições integrais das intervenções. No Gráfico 2 é possível observar que os temas 'funcionamento e papel do Conselho/ controle social' e 'políticas específicas e programas de saúde', juntos, concentraram 50\% do tempo de debates (1.258.251 em 2.395.877). Constata-se, ainda, que relativamente pouco tempo era destinado a temas refe- 
rentes às condições de trabalho e emprego e de exercício profissional 'trabalhista/profissionais de saúde' - ou à própria 'organização dos serviços de saúde'. Ou seja, as reuniões plenárias dedicaram metade das suas discussões a questões referentes ao próprio Conselho e ao papel do controle social no âmbito do SUS, assim como à análise de diversas políticas específicas e programas de saúde implementados ou em fase de proposta para implementação.

Gráfico 2 - Número e percentual de caracteres por temas discutidos nas reuniões plenárias. Conselho Nacional de Saúde (CNS) - 2005

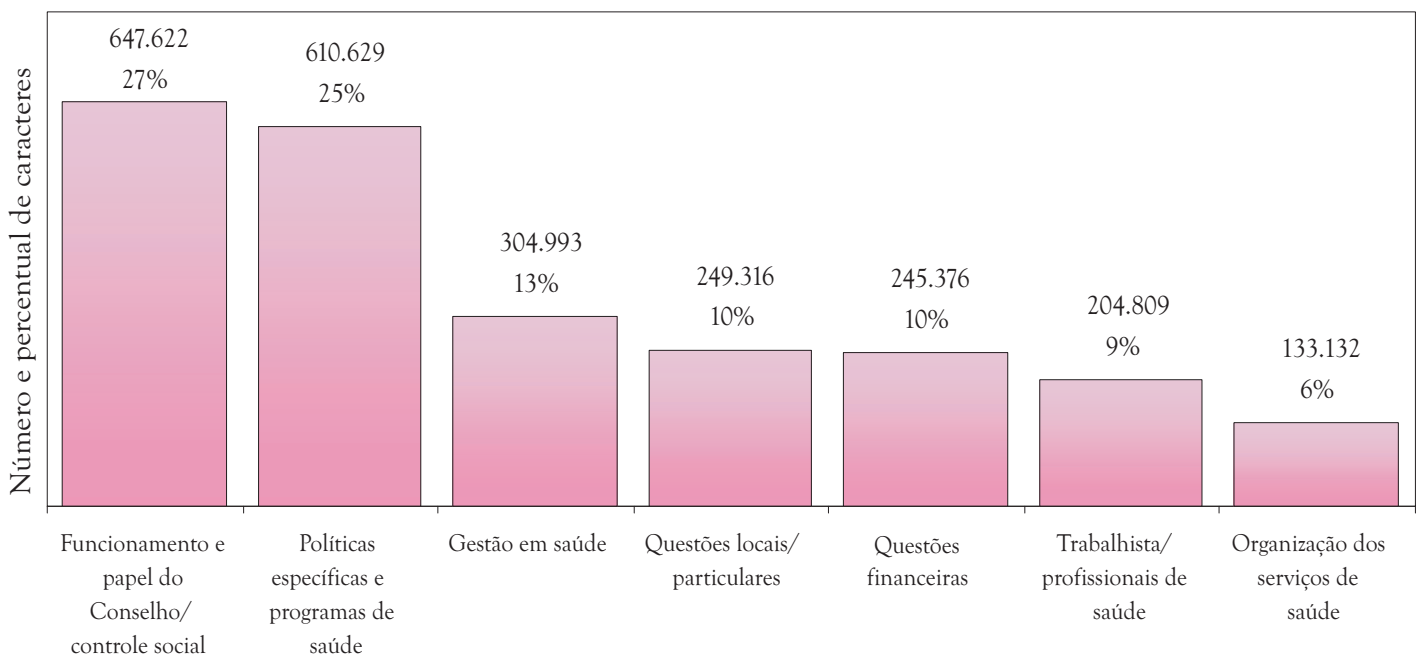

Temas

Fonte: Brasil, 2005.

A predominância de assuntos referentes ao próprio controle social é criticada por alguns conselheiros (G. S., entrevista, 4/5/2006; L. M., entrevista, 16/1/2006; W. J., entrevista, 20/9/2006). Para eles, gastava-se muito tempo nas reuniões com a escolha de representantes do Conselho para atuarem em outros fóruns ou instituições e nas discussões relativas aos próprios mecanismos participativos do SUS, particularmente as conferências de saúde. $\mathrm{O}$ excesso de tempo destinado às questões como 'informes gerais', 'escolha de representantes do Conselho em atividades externas' e 'conferências' resultaria na redução do tempo destinado à discussão de temas importantes, como a 'organização dos serviços de saúde' ou a execução orçamentária dos projetos, por exemplo. 
Porque a gente teve duas conferências, a gente passou pela discussão do processo eleitoral, que foi difícil, foi complicado, foi polêmico pra caramba, e isso de uma certa maneira mexe com a agenda normal do Conselho. Porque nós fizemos três conferências temáticas sucessivamente: trabalhador, indígena e gestão no trabalho e educação na saúde. Isso demandou tempo e discussões. (G. S., entrevista, 4/5/2006)

O Gráfico 3 permite verificar quem eram os sujeitos das intervenções. Nas reuniões, quase $60 \%$ do tempo - aqui indicado pelo número de caracteres - foi ocupado por intervenções de representantes de entidades sociais (58\% 791.679 em 1.353.217). ${ }^{10}$ Em contraste, apenas 2\% do tempo era ocupado por intervenções dos conselheiros provenientes de entidades de mercado (24.203 em 1.353.217). Chama a atenção o tempo despendido com intervenções de não-conselheiros. Estes participantes concentravam suas falas no tema das 'políticas específicas e programas de saúde', o qual, como foi mostrado no Gráfico 2, era o segundo tema que mais tomava tempo das reuniões. As longas intervenções dos não-conselheiros, em geral especialistas em assuntos técnicos específicos, eram para exposição de diretrizes, fundamentos ou realizações referentes a determinadas políticas ou programas sobre os quais eram convidados a prestar esclarecimentos. Por isso, como pode ser observado no Gráfico 4, havia grande concentração de falas de não-conselheiros nesse tema.

${ }^{10}$ Observe-se que o número total de caracteres no Gráfico 3 - 1.353.217 - é menor do que o apresentado no Gráfico 2 - 2.395.877. Isso ocorre porque tanto as intervenções do ministro da Saúde quanto as da Secretaria Executiva estão excluídas da contagem realizada para a elaboração do Gráfico 3, que trata do volume das intervenções por tipos de participante. A grande diferença ocorre porque as falas do ministro são muito extensas, uma vez que são transcritas integralmente nas atas. Por ser um participante especial e pelo modo peculiar com que suas falas apareciam nas atas, optou-se por excluí-las para evitar distorções. As manifestações da Secretaria Executiva também foram desconsideradas no Gráfico 3, porque não poderiam ser enquadradas em nenhum tipo de conselheiro e, ao mesmo tempo, não poderiam ser consideradas como de participante não-conselheiro devido ao seu papel peculiar na definição da agenda do fórum. 
Gráfico 3 - Número de caracteres por tipos de participantes: sociais, governamentais, de mercado e não-conselheiros. Conselho Nacional de Saúde (CNS) - 2005

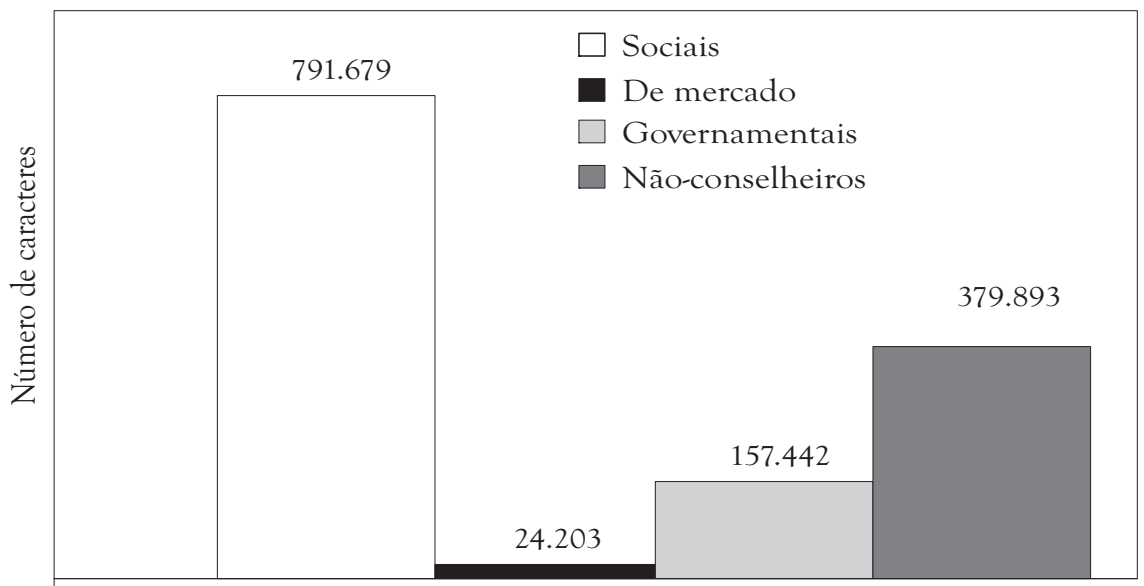

Fonte: Brasil, 2005.

Gráfico 4 - Percentual de caracteres por temas discutidos nas reuniões plenárias, segundo o tipo de representação dos participantes. Conselho Nacional de Saúde (CNS) - 2005

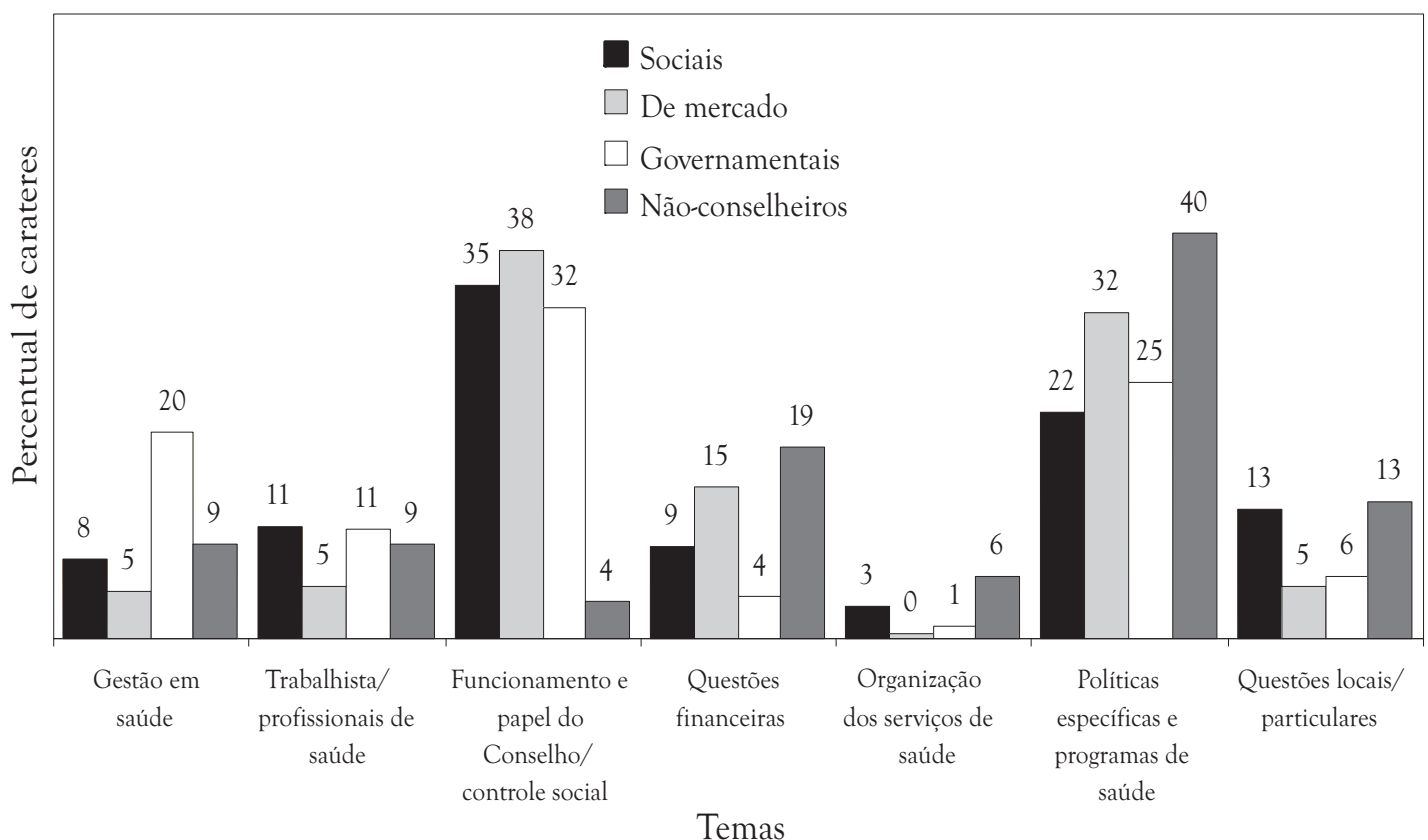

Fonte: Brasil, 2005. 
O Gráfico 4 também permite que se observe como os diferentes tipos de participantes distribuíram o tempo de intervenção entre os assuntos tratados durantes as reuniões examinadas. À exceção dos nãoconselheiros, todos os demais participantes concentraram suas intervenções na temática 'funcionamento e papel do Conselho/controle social' isto porque, como pode ser visto no Gráfico 2, o tema, sozinho, ocupou quase 30\% do tempo total de debates (647.622 em 1.353.217).

O Gráfico 2 mostra ainda que as 'políticas específicas e programas de saúde' e as 'questões financeiras' estavam em segundo e quinto lugares, dentre os temas que mais longamente foram discutidos - temas sobre os quais se concentraram as intervenções dos participantes não-conselheiros, como demonstra o Gráfico 4. Elas representaram 40\% e 19\%, respectivamente, do total do tempo das falas desses participantes nas reuniões examinadas (150.992 e 70.947 em 379.893). Os não-conselheiros eram chamados ao Conselho principalmente para apresentar e debater políticas, programas e questões relacionadas ao financiamento em saúde ou para prestar esclarecimentos sobre elas. Isso demonstra que o Conselho investia na busca de subsídios externos para seu processo de deliberação, especialmente em assuntos complexos ou controversos.

O tempo dispensado para a discussão de questões relacionadas às condições de trabalho e emprego e de exercício profissional na área da saúde foi uniformemente baixo para todos os grupos de participantes. Apesar de o fórum comportar a existência da Mesa Nacional de Negociações, o pouco tempo dedicado ao tema pode ser uma indicação de que o Conselho não era uma instância importante de negociações trabalhistas no SUS.

Os representantes governamentais eram os que mais discutiam as questões relacionadas à gestão em saúde, como seria de se esperar. Entretanto, os representantes de entidades sociais, que eram os que mais se envolviam nas atividades do Conselho - considerando os indicadores até aqui examinados -, destinaram para os temas 'gestão em saúde', 'questões financeiras' e 'organização dos serviços de saúde', somados, apenas 20\% do tempo total de suas intervenções (157.586 em 791.679). Isso corrobora a apreciação de alguns entrevistados (G. S., entrevista, 4/5/2006; L. M., entrevista, 16/1/2006; W. J., entrevista, 20/9/2006) sobre o pouco tempo que era despendido nas reuniões plenárias com o debate de temas centrais para definição das políticas de saúde.

Até aqui, examinou-se o processo de formação da agenda de debates do fórum e o peso relativo, nessa agenda, dos grandes temas em torno dos 
quais se estruturaram as discussões, e ainda em que medida os diferentes tipos e categorias de participantes concentraram suas intervenções sobre cada um desses temas. Agora a indagação recai sobre como os diversos tipos de participantes intervinham, ou seja, procura-se caracterizar o tipo de intervenção que era feita. Para isso, foi construída uma tipologia, formada por sete tipos de 'tons' de intervenções:

- informativas: apresentavam informações, análises, comentários, pesquisas, diagnósticos, avaliações, voltadas a subsidiar as discussões e deliberações do Conselho ou informar seus membros sobre assuntos em pauta;

- de questionamento ou esclarecimento: solicitavam esclarecimentos ou informações, ofereciam-se respostas a tais solicitações;

- de denúncia: discutiam problemas graves e/ou irregularidades no funcionamento ou na gestão de políticas, programas e serviços de saúde;

- de reivindicação ou sugestão: apresentavam reivindicações ou sugestões de ação e, concomitantemente, eram definidas propostas de encaminhamento;

- de proposição: expunham propostas claras de encaminhamento para o objeto da discussão;

- de discordância ou crítica: discordavam de intervenções, propostas, reivindicações ou sugestões (ou faziam críticas a elas) apresentadas no âmbito do Conselho (seja pelos próprios participantes da reunião, seja por agentes externos ao Conselho);

- de concordância ou apoio: expressavam concordância ou apoio explícito às intervenções, propostas, reivindicações ou sugestões apresentadas no âmbito do Conselho, seja pelos próprios participantes da reunião, seja por agentes externos ao Conselho.

O Gráfico 5 mostra a distribuição percentual do tempo das intervenções - também aqui indicado pelo número de caracteres - pelo tipo de manifestação. Em primeiro lugar, observe-se que a grande dimensão das intervenções informativas (39\% - 724.514 em 1.844.494) $)^{11}$ é uma indicação

${ }^{11}$ As diferenças nas totalizações de número de caracteres nos temas de intervenção (2.395.877) e nos tipos de intervenção $(1.844 .494)$ devem-se ao procedimento de categorização adotado na pesquisa. Por um lado, um pequeno número de trechos das atas não se enquadrava em nenhuma categoria de tema ou tipo, não sendo, assim, contabilizado. Por outro lado, determinados trechos, na medida em que se inseriam em mais de uma categoria, foram categorizados e, assim, contabilizados mais de uma vez. Desse modo, os dados apresentados não se referem ao número total de caracteres das atas, mas sim ao número de caracteres resultante dos processos de categorização. 
da forte preocupação em buscar subsídios - internamente, pela realização de análises e diagnósticos, e, externamente, pelo convite à participação de não-conselheiros - para orientar as discussões e decisões do Conselho. Em segundo lugar, somando-se as intervenções de 'proposição' e 'reivindicação ou sugestão', que compuseram 18\% e 17\% dos registros em ata $(328.900$ e 318.363 em 1.844.494), respectivamente, chega-se a mais de um terço de intervenções que se caracterizaram pela apresentação de propostas ou, ao menos, de idéias e demandas de ações na área da saúde. Em terceiro lugar, as intervenções de 'questionamento ou esclarecimento', com 11\% dos caracteres registrados em atas (207.164 em 1.844.494), indicam que, ao menos em parte, o Conselho se constituía também em um espaço de acesso a determinadas informações e conhecimentos para aqueles que nele intervinham. Em quarto lugar, as intervenções de 'discordância ou crítica', que responderam por $10 \%$ do volume das intervenções (177.180 em 1.844.494), e as intervenções de 'concordância ou apoio', que representaram apenas 3\% dos registros (56.664 em 1.844.494), por um lado podem expressar as dinâmicas de conflitos e alianças dentro do Conselho; ${ }^{12}$ por outro, o pouco tempo despendido em manifestações desse tipo pode indicar que as definições de posições a serem assumidas pelos atores ante os temas em debate e as negociações para a construção de consensos entre subgrupos de conselheiros realizavam-se fora do espaço das plenárias. Por fim, os apenas 2\% de registros relativos à 'denúncia' (31.709 em 1.844.494) são indício de que o Conselho não era um espaço prioritário para denúncia de problemas ou irregularidades específicas.

\footnotetext{
${ }^{12}$ As intervenções de concordância podem ter tido dimensões maiores. Pode-se supor a existência de um provável viés subjacente no registro de intervenções de 'concordância e apoio', uma vez que intervenções de suporte ou adesão a outras intervenções, por não agregarem nenhuma informação, proposta ou sugestão nova, tendiam a ser sub-registradas nas atas.
} 
Gráfico 5 - Percentual de caracteres por tipo de intervenção nas reuniões plenárias. Conselho Nacional de Saúde (CNS) - 2005

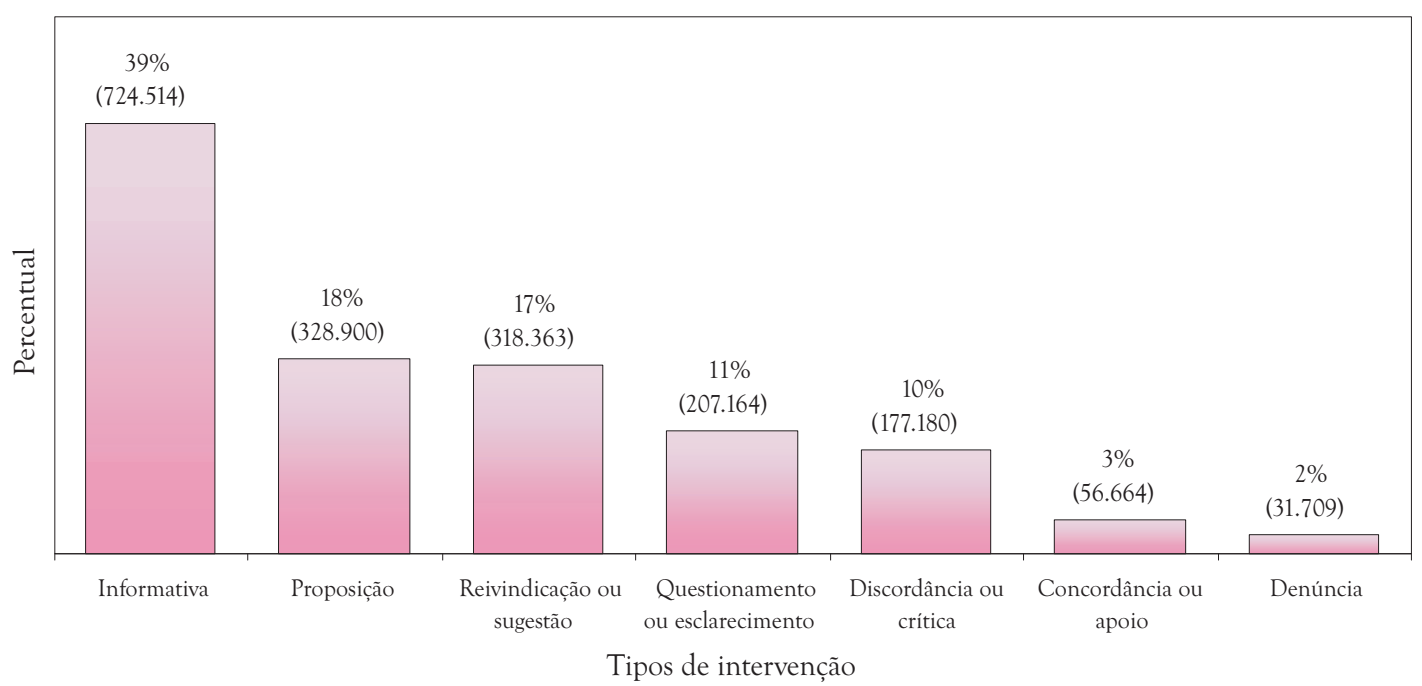

Fonte: Brasil, 2005.

Identificados os tipos de intervenção e o tempo dedicado a sua discussão, permanece a indagação sobre quem seriam os responsáveis por essas falas. O Gráfico 6 apresenta os percentuais referentes ao tempo que cada tipo de participante dedicou a cada tipo de intervenção.

Os representantes de entidades sociais são aqueles que mais se manifestaram em praticamente todos os tipos de intervenção, à exceção das intervenções informativas. Eles foram responsáveis por mais de dois terços das intervenções de tipo 'concordância e apoio', 'discordância ou crítica', 'denúncia' e 'proposição'. Chama a atenção no Gráfico 6 o fato de que, somadas, $50 \%$ de suas falas destinavam-se a apresentar 'reivindicação ou sugestão' (194.085 em 750.841) e 'proposição' (179.034 em 750.841). Mais do que no caso dos indicadores examinados anteriormente, a grande concentração do tempo de debates em manifestações propositivas realizadas por conselheiros provenientes de entidades sociais pode ser uma evidência de seu protagonismo nos debates. 
Gráfico 6 - Percentual de caracteres por tipo de intervenção nas reuniões plenárias, segundo os tipos de participantes: sociais, governamentais, de mercado e não-conselheiros. Conselho Nacional de Saúde (CNS) - 2005

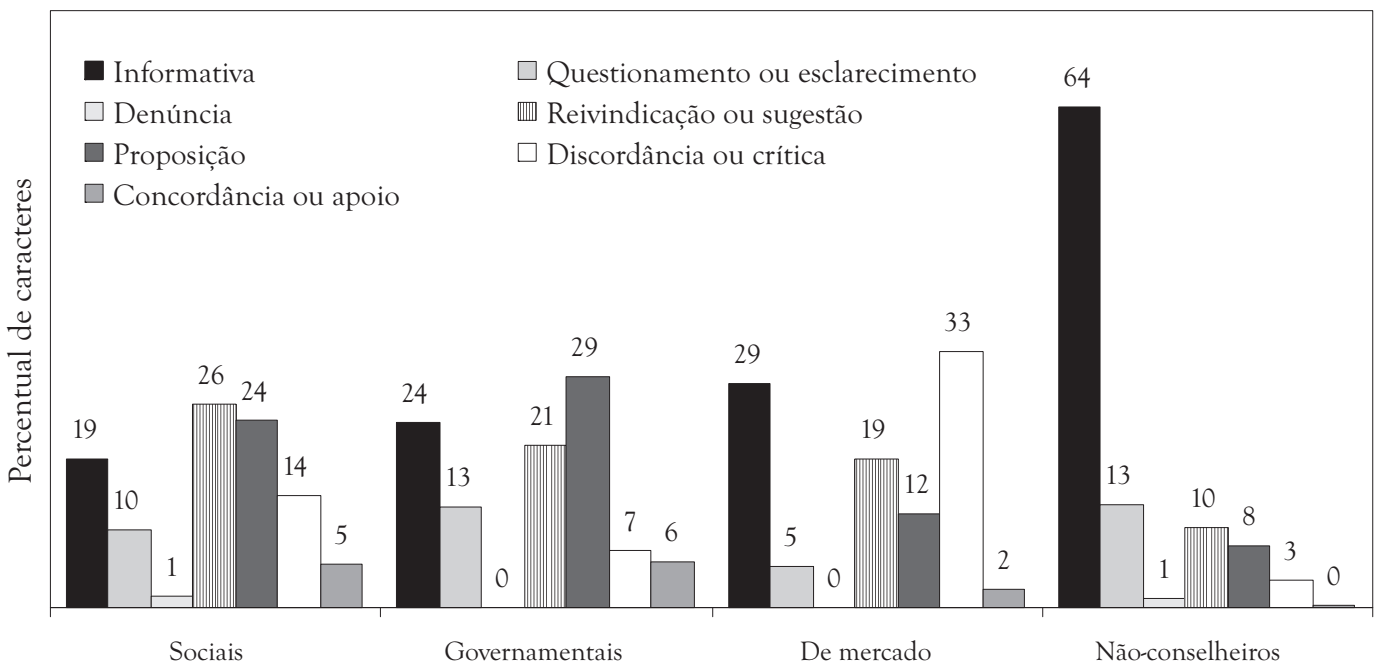

Tipos de participante

Fonte: Brasil, 2005.

Os representantes governamentais utilizaram o espaço do Conselho, principalmente, para apresentar 'proposição' (29\%, 50.548 em 171.755), oferecer 'informação' (24\%, 40.742 em 171.755) e apresentar 'reivindicação ou sugestão' (21\%, 35.610 em 171.755). Somados, esses tipos de intervenção representam $74 \%$ do tempo de duração de suas falas. O Conselho apresentava-se para os gestores federais de saúde - que eram os representantes de órgãos governamentais mais ativos nos debates do fórum - como um espaço importante para eles apresentarem suas propostas e sugestões, buscando com isso o respaldo social e político para elas.

Os conselheiros provenientes de entidades de mercado concentraram suas intervenções na expressão de 'discordância ou crítica'. Do volume total de suas falas, 33\% (7.919 em 24.179) foram utilizadas para questionar propostas, demandas e argumentos apresentados pelos outros participantes do fórum, enquanto 29\% foram 'informativas' (6.906 em 24.179). Registre-se, entretanto, que provavelmente devido a sua pequena freqüência às reuniões, suas falas representaram apenas $2 \%$ do total de registros em ata em todos os tipos de intervenções. Isso indica, portanto, que a parti- 
cipação dos conselheiros de mercado nas discussões das reuniões plenárias era inexpressiva, assumindo uma relativa relevância na hora de manifestar posições de discordância ou crítica. Dada a importância do setor privado no contexto do SUS, pode-se supor que os atores de mercado não deixaram de exercer influência sobre a política de saúde nacional, mas o faziam em outros espaços e por outros canais de participação política.

Como seria de se esperar, os participantes não-conselheiros concentraram suas manifestações nas intervenções 'informativas'. Do total de suas falas, 64\% foram informativas (250.207 em 392.432), 13\% destinaram-se a 'questionamentos ou esclarecimentos' (51.455 em 392.432), provavelmente mais esclarecimentos do que questionamentos, e 10\% apresentavam 'reivindicação ou sugestão' (40.241 em 392.432). Também neste caso é mais provável que tenham predominado as sugestões. Os três tipos de manifestações, que se destinavam a oferecer informações ou eram decorrentes de esclarecimentos ou sugestões derivadas de exposição inicial, somados, responderam por $87 \%$ de todo o volume de intervenções de não-conselheiros.

Ao encerrar esta seção, pode-se concluir que a dinâmica de funcionamento das reuniões plenárias do Conselho caracterizava-se, basicamente, pelos aspectos indicados a seguir. Havia uma concentração dos debates nos temas 'funcionamento e papel do Conselho - controle social' e 'políticas específicas e programas de saúde'. Para eles, dirigiam-se as intervenções dos principais agentes que intervinham no fórum: os representantes de órgãos governamentais e, especialmente, de entidades sociais. Havia também um forte sentido formativo nas discussões, com a busca permanente de subsídios para orientar o processo de tomada de decisões. Os participantes nãoconselheiros tinham um importante papel na oferta de informações e esclarecimentos. Ocorria, ainda, uma intensa dinâmica de debate e deliberação, que era hegemonizada pelos conselheiros que representavam organizações da sociedade civil com relação a propostas de políticas e programas, formuladas, em grande medida, pelos gestores públicos. Por fim, o Conselho desenvolvia uma atividade permanente de monitoramento da ação governamental na área da saúde.

Tal conclusão traz à discussão um tema central para este estudo, que ao mesmo tempo é objeto de profundo debate no próprio CNS: qual o papel do CNS na arena decisória da área da saúde no Brasil? Com base na análise 
realizada ao longo desta seção, foi possível formular respostas para esta questão. O Conselho se constituía em uma instância importante de fiscalização da execução da política de saúde, desenvolvendo uma atividade intensa de busca de informações sobre a atuação das instituições públicas e privadas da área da saúde. ${ }^{13}$ Além do papel fiscalizador, o Conselho apresentava uma constante atividade deliberativa, ${ }^{14}$ durante a qual eram apresentadas propostas de políticas e programas na área da saúde, que eram discutidas com relativa profundidade, e no final do processo havia uma tomada de posição do Conselho sobre elas. Por fim, junto com a fiscalização e a deliberação, o fórum apresentava um importante papel articulador, criando um espaço de/para a convergência e intervenção coletiva de um conjunto de atores e instâncias comprometidos com o controle social e o SUS.

O Conselho constituía-se em um espaço de interação social, que oferecia recursos para viabilizar a participação de conselheiros em eventos e atividades que ocorriam em diferentes regiões do país, investindo na criação de mecanismos de interlocução e integração com os conselhos estaduais e municipais. Desse modo, era um fórum privilegiado de articulação de participantes importantes da rede da política de saúde, em especial da comunidade de política que se formava sob a liderança do Fentas. Por um lado, a atuação da comunidade no Conselho consolidava suas posições e permitia a articulação com outros atores em nível nacional. Ao mesmo tempo, favorecia a demarcação das diferenças entre ela e o movimento sanitário, na disputa pela primazia na constituição da agenda de debates e na incorporação de propostas pelos decisores governamentais. Por outro lado, no Conselho, as duas comunidades construíam alianças circunstanciais, principalmente na defesa dos princípios fundadores do SUS, contra aqueles que os atacavam, vistos nesse caso como inimigos comuns.

${ }^{13}$ Esse papel é ilustrado pelo intenso debate no Conselho, no período analisado, sobre a questão da saúde suplementar.

${ }^{14}$ O termo 'deliberativo' é marcado por uma relativa ambigüidade, exigindo esclarecimento. Por um lado, 'deliberativo' refere-se a um processo público de discussão, no qual diferentes atores podem intervir livremente, produzindo certo resultado como posição coletivamente construída no debate. É esse o sentido aqui utilizado. Por outro lado, 'deliberativo' refere-se, também, a uma atribuição de determinada instância, legalmente definida, de produzir decisões que devem ser obrigatoriamente acatadas. Assim, é possível haver um processo 'deliberativo', no primeiro sentido, sem que necessariamente a instância seja de fato deliberativa, no segundo sentido. 


\section{O Poder no Conselho e o Poder do Conselho}

Um aspecto evidente na análise dos dados apresentados ao longo deste capítulo é a profunda assimetria, observável no interior do Conselho, no que se refere à capacidade de participar efetivamente das discussões e deliberações. Todas as informações apresentadas mostram a existência de um pequeno núcleo de participantes, na sua quase totalidade vinculados a entidades sociais - e na sua maioria originários de organizações de profissionais e trabalhadores de saúde -, que ocupava uma posição dominante no interior do fórum, considerando praticamente todos os indicadores examinados.

Com base em um discurso orientado para a defesa radical dos princípios do SUS e das resoluções das Conferências de Saúde, observou-se a existência de uma articulação relativamente sólida entre uma parcela importante dos representantes de entidades de profissionais e trabalhadores de saúde (com exceção dos representantes das entidades médicas); de entidades étnicas, de gênero e de portadores de patologias ou deficiências; de associações comunitárias e movimentos sociais e de trabalhadores, não especificamente da área da saúde. Essa articulação tinha características que permitem considerá-la como um elemento estruturador importante de uma comunidade de política. Constituía-se como um conjunto relativamente estável de indivíduos ou organizações, conectados a outros que não tinham representação direta no Conselho, que dividiam os mesmos valores e visão sobre quais deveriam ser os resultados da política setorial.

Em contraposição a essa articulação, os setores vinculados aos interesses do mercado na área da saúde - sejam eles representantes das entidades empresariais, sejam dos prestadores de serviços privados - ficavam em uma posição subordinada no Conselho. A subordinação não se manifestava apenas em relação ao número relativamente menor de participantes, mas também em termos da possibilidade de envolvimento ativo nas discussões e deliberações.

Já o grupo dos representantes governamentais, mesmo sendo menor que o dos conselheiros oriundos de organizações da sociedade civil, apresentava uma posição de centralidade no Conselho. Os representantes dos gestores da saúde, particularmente da esfera federal, tinham predomínio na definição da agenda de debates do fórum, uma vez que detinham o protagonismo em termos da formulação das políticas, ao mesmo tempo que controlavam a sua execução. Mesmo quando não eram eles que decidiam os temas que seriam incluídos nas pautas, os questionamentos e pedi- 
dos de esclarecimentos eram, em geral, dirigidos a eles. Além de serem os decisores públicos da área, suas trajetórias políticas os aproximavam da comunidade de política formada pelo movimento sanitário 'histórico'. Desse modo, as decisões que tomavam eram influenciadas pela existência dessa identidade ou pelos laços que os ligavam a essa comunidade reformista.

Em 2005, observou-se no Conselho a existência de uma relação ambígua entre os integrantes do grupo liderado pelos conselheiros provenientes de entidades sociais e o grupo dos representantes governamentais, particularmente dos gestores federais de saúde. De um lado, os primeiros encaravam a atuação dos gestores como um obstáculo para a efetivação do SUS, assim estes se tornavam alvos de intensas críticas, cobranças, denúncias e reivindicações (G. S., entrevista, 4/5/2006; Q. F., entrevista, 2/6/2006). De outro, na medida em que vários representantes dos gestores federais de saúde identificavam-se e eram identificados com a construção e defesa do SUS, eles eram também vistos como aliados fundamentais na confrontação com outros atores e interesses, estes sim considerados como os verdadeiros 'inimigos' do SUS. Entre os últimos estavam os atores do mercado privado da saúde - hospitais, policlínicas e laboratórios privados, indústria farmacêutica e seguradoras de saúde - e os atores políticos com eles alinhados parlamentares e gestores identificados com partidos de direita (I. E., entrevista, 23/5/2006; J. R., entrevista, 31/5/2006; N. G., entrevista, 31/5/2006; Q. F., entrevista, 2/6/2006).

Assim, havia uma oscilação entre momentos de intensos conflitos entre representantes de entidades sociais e dos gestores federais de saúde e momentos de profunda convergência de interesses e propostas. Os conflitos ocorriam principalmente em relação ao papel do controle social no SUS. Em termos mais específicos, as divergências concentravam-se em visões divergentes sobre que instância deveria comandar a política de gestão participativa no sistema. A articulação dos representantes de organizações da sociedade civil atribuía ao Conselho esse papel, enquanto os gestores federais defendiam a prerrogativa do Ministério da Saúde de decidir e gerenciar a gestão participativa no SUS. No entanto, ao tratar da busca da ampliação dos recursos financeiros destinados à área da saúde, os dois grupos de conselheiros atuavam juntos e em harmonia.

No entanto, se essa era a configuração das relações estruturadas no interior do Conselho, qual seria a posição do Conselho na configuração 
das relações estruturadas na arena decisória da área? Foi possível identificar uma clara diferença entre as duas configurações. A posição dos atores internamente ao Conselho parece não refletir sua posição no âmbito mais amplo da política de saúde. Neste, conforme ressaltaram vários entrevistados (J. R., entrevista, 31/5/2006; O. G., entrevista, 22/5/2006; P. G., entrevista 31/5/2006), entidades médicas, prestadores privados de serviços, indústria farmacêutica, parlamentares e, especialmente, gestores públicos, principalmente nas comissões intergestores, ocupavam posições dominantes - alterando e, no limite, invertendo a hierarquia de posições identificada e caracterizada no Conselho.

A institucionalização das comissões intergestores tripartite e bipartites, a partir da segunda metade da década de 1990, colaborou para que o CNS não se constituísse como um órgão decisório da gestão em saúde no país, porque as questões que diziam respeito ao financiamento, à descentralização e à estruturação e funcionamento do SUS passaram a ser tratadas nas comissões intergestores (Levcovitz, Lima \& Machado, 2001; J. R., entrevista, 31/5/2006; N. G., entrevista, 31/5/2006). Para os idealizadores das comissões, que na época eram gestores municipais de saúde, o Conselho seria um espaço político de discussões e deliberações sobre a natureza das políticas. O exercício de outro papel viria a deturpar suas finalidades (L. M., entrevista, 16/1/2006; W. J., entrevista, 20/9/2006). Desse modo, o desenho institucional do sistema deslocou o processo decisório para instâncias colegiadas de pactuação federativa. Nelas, os atores sociais não tinham assento ou voz, o que restringia as possibilidades da articulação de atores sociais que predominava internamente no Conselho - e, portanto, da comunidade de política, por trás dessa articulação, de utilizar esse importante canal para apresentar suas propostas aos decisores políticos da área.

Assim, observou-se que a capacidade de o Conselho influir nos centros de decisão e execução da política dependia, em grande medida, da forma como se estruturaram as relações com os gestores, especialmente com os gestores federais. A posição do Conselho na arena decisória da área acabava sendo, em grande medida, dependente da forma como os gestores federais se posicionavam em relação ao fórum. Dependia, também, do modo como os gestores se relacionavam com os atores e interesses que hegemonizavam as discussões e deliberações do Conselho. Trechos de uma ata e de uma das entrevistas exemplificam essa situação: 
Esse Conselho tem que funcionar em parceria absoluta com o Ministro da Saúde. Eu não vou aceitar que o Conselho cobre do ministro. Não vai cobrar, porque senão... Eu não aceito ser cobrado pelo Conselho. Vocês tenham clareza do que estou falando: se o Conselho não for meu parceiro e eu for colocado como uma instância de poder para ser cobrado, eu não vou acatar esse Conselho como deliberativo. Ele será consultivo. (Brasil, 2005 - intervenção do ministro da Saúde)

Ele [o ministro X] não tinha respeito nenhum com o Conselho. Ele não foi a nenhuma reunião do Conselho. Ele não ia a nenhuma reunião do Conselho e mandava os assuntos. A gente deliberava e ele tramitava contra a decisão do Conselho. Ele mandava pra lá, a gente votava contra e ele implementava. Ou, então, ele implementava para depois mandar. Já estava funcionando no Brasil inteiro e ai ele mandava pra discutir no Conselho. (...) Então o Conselho, muitas vezes, deliberou contra e aí jogou na imprensa para ver se conseguia reverter essa questão. E, algumas vezes, quando não se tinha que eram politicas incorretas, a gente aprovava, mas registrando e fazendo um protesto: que está correto, mas deveria ter passado antes no Conselho. (K. L., entrevista, 13/6/2006)

No entanto, tal situação não significa que o Conselho estivesse em uma posição passiva, meramente subordinada às oscilações na postura dos gestores. Ao contrário, o fórum participava ativamente do processo de construção da sua posição nas relações entre os atores e instâncias da política de saúde. Segundo o depoimento de vários conselheiros, em diversos momentos o Conselho entrou em choque com o gestor.

Foi possível ainda observar um esforço do Conselho, liderado pelos atores que hegemonizavam seu processo decisório interno, em intensificar a atuação juntamente com os demais fóruns de controle social na área da saúde: os conselhos estaduais e municipais de saúde, além das conferências de saúde (H. A., entrevista, 5/5/2006; J. R., entrevista, 31/5/2006). Na medida em que esses fóruns se constituíam como uma rede densa e disseminada em todo o país, envolvendo algumas dezenas de milhares de conselheiros, construir uma articulação com eles adquiria um sentido estratégico para que o fórum se constituísse ou se mantivesse como um lugar central no processo de construção e acompanhamento da política de saúde. ${ }^{15}$

15 É, pelo menos em parte, por esse motivo que havia uma forte preocupação no Conselho em tentar controlar e, no limite, monopolizar a relação com os conselhos municipais e estaduais, investindo em iniciativas de comunicação, formação de conselheiros e produção de informações sobre os conselhos, entre outras. Essa preocupação foi uma das fontes de conflito permanente com a Secretaria de Gestão Participativa do Ministério da Saúde. 
Ao mesmo tempo, era um modo de fortalecer e expandir nacionalmente a posição da comunidade de política que hegemonizava as atividades no Conselho.

Além da atuação junto às instâncias e atores do controle social, o Conselho procurava atuar no Congresso Nacional, que muitas vezes discutia propostas referentes à política de saúde sem que estas tivessem sido objeto de deliberação do fórum. Esse problema, em certa medida, decorria de uma 'competição' entre os dois mecanismos de representação de interesses que hoje convivem no Brasil: as instituições da representação partidário-eleitoral e as instituições do controle social. Como tentativa de enfrentar a questão, os entrevistados destacaram a existência de um esforço contínuo dos conselheiros em pressionar os parlamentares para evitar que decisões fossem tomadas contrariando as deliberações do Conselho (J. R., entrevista, 31/5/2006). Ao mesmo tempo, eles procuravam apoio parlamentar para projetos em tramitação no Congresso que eram considerados relevantes pela maioria dos conselheiros. Desse modo, constituía-se uma 'parceria' com a Frente Parlamentar da Saúde, que tendia a apresentar posições convergentes às apresentadas pelo fórum (M. C., entrevista, 23/5/2006). Por meio dessas e de outras iniciativas, o Conselho procurou construir parcerias, estruturar relações, ampliar sua influência, de forma a se fortalecer e, conseqüentemente, fortalecer seus atores hegemônicos, na arena decisória da área.

\section{Considerações Finals}

Em 2005, o CNS se organizava em instâncias que cumpriam funções definidas e dispunham de considerável apoio material e humano para a realização de suas atividades. Com seus quarenta membros titulares, as principais instâncias do fórum eram o plenário, as comissões, os grupos de trabalho e a comissão de coordenação geral. A Secretaria Executiva oferecia apoio administrativo, coordenando um contingente de 34 servidores e estagiários.

A análise feita procurou responder a duas questões básicas: como se estruturavam as relações entre os atores no interior do Conselho e qual o 'papel' do Conselho na arena decisória da área da saúde. A primeira indagação foi respondida nas seções que trataram da atuação dos conselheiros e da dinâmica das discussões nas reuniões do fórum. Constatou-se que havia predomínio dos conselheiros que representavam entidades sociais - dentre estes, das categorias de representantes de associações comunitárias e movi- 
mentos sociais, de entidades étnicas, de gênero e de portadores de patologias ou deficiências e, especialmente, de organizações de profissionais e trabalhadores da saúde.

Os conselheiros provenientes de organizações da sociedade civil foram também os mais assíduos às reuniões, aqueles que se manifestaram com maior freqüência, que coordenaram a maior parte dos pontos de pauta e que mais vezes representaram o Conselho em atividades externas. Havia, portanto, uma preponderância relativa desses conselheiros na condução das discussões e deliberações, diante da menor participação de conselheiros governamentais e do diminuto envolvimento de representantes de organizações de mercado. Um 'núcleo duro' de seis conselheiros provenientes de entidades sociais tinha significativa influência nas discussões e deliberações que ocorriam no fórum, levando-se em conta seu elevado nível de participação nas atividades do Conselho. Esse núcleo era formado por quatro conselheiros provenientes de organizações de profissionais e trabalhadores de saúde e dois representantes de entidades étnicas, de gênero e de portadores de patologias ou deficiências.

A dinâmica de funcionamento das reuniões plenárias do Conselho era caracterizada por quatro aspectos básicos. Em primeiro lugar, as discussões concentravam-se nos temas 'funcionamento e papel do Conselho/controle social' e 'políticas específicas e programas de saúde'. Em segundo, a maior parte do tempo das reuniões era despendida em longas intervenções informativas, demonstrando que havia a busca permanente de subsídios para orientar o processo de tomada de decisões. Os participantes não-conselheiros tiveram um importante papel na oferta de informações e esclarecimentos. Em terceiro lugar, as reuniões plenárias e a sua preparação envolviam intensos debates e processos de deliberação, em que tinham influência prepoderante os representantes de organizações sociais. As discussões tratavam principalmente do próprio Conselho e do controle social ou das políticas e programas de saúde. Em quarto lugar, o fórum desenvolvia uma atividade permanente de monitoramento da ação governamental na área da saúde, principalmente em relação à execução orçamentária.

O fórum se constituía em uma instância importante de fiscalização da execução da política de saúde, desenvolvendo ações constantes de busca de informações sobre a atuação das instituições públicas e privadas atuantes na área da saúde. Demonstrava intensa atividade deliberativa, com apresentação e debate de propostas de políticas e de programas de saúde, tomada de 
posição sobre elas. Tinha ainda um importante papel articulador de atores, individuais e coletivos, comprometidos com o controle social e com os princípios fundamentais do SUS.

O Conselho era também um dos lugares centrais de conexão entre participantes importantes da rede da política de saúde, em especial da nova comunidade de política que se formara no final dos anos 90. Com a liderança de seus membros mais atuantes, procurou tornar-se o principal espaço de articulação com os conselhos estaduais e municipais. $\mathrm{O}$ controle do fórum era fundamental para a consolidação nacional dessa comunidade, permitindo a busca e a identificação de aliados, a difusão de suas idéias e propostas, em um contexto de disputa com o movimento sanitário pela condição de herdeiro legítimo do movimento reformista fundador do SUS. Por isso, o próprio Conselho e os demais mecanismos de participação da área tornaram-se os principais objetos de discussão nas reuniões plenárias e foram tão acirrados os debates, entre o fórum e o Ministério da Saúde, em torno do controle sobre a gestão participativa no SUS.

O Conselho não era um local de construção de consensos ou explicitação de conflitos sobre temas candentes, como o financiamento da saúde, as questões relacionadas ao trabalho em saúde ou a própria organização dos serviços. Isso se deveu, em parte, à criação das comissões intergestores, as quais, depois de 1993, passaram a se constituir como o principal fórum decisório e de coordenação vertical do sistema de saúde. Articulado a esse fator, estava o crescimento da importância política dos gestores estaduais e, principalmente, municipais no âmbito do SUS, os quais elegeram como principal fórum de atuação as comissões intergestores. O papel relativamente secundário do Conselho no processo decisório da área foi resultado também da estratégia adotada pelos conselheiros que hegemonizavam os trabalhos do fórum. Eles optaram por concentrar boa parte das discussões no funcionamento do próprio Conselho e no controle social no SUS e procuraram restringir a influência dos representantes de entidades de mercado, dos médicos e de gestores no Conselho. Esses atores, no entanto, não deixaram de ocupar posições centrais na arena política da área; eles apenas reduziram a sua influência no Conselho e não no contexto da política. A capacidade do Conselho de influir nos centros de decisão e execução da política continuou dependendo, em grande medida, da forma como se estruturaram as relações dos conselheiros e do próprio fórum com os gestores, especialmente com os gestores federais. 
Assim, se, por um lado, os atores sociais preponderavam na estrutura de poder do fórum, principalmente aqueles que representavam organizações de profissionais e trabalhadores de saúde; por outro, o Conselho não tinha uma posição garantida e estável no centro do processo decisório nacional da área da saúde. É inegável, no entanto, que exercia um importante papel: fiscalizando a implementação de ações, deliberando sobre assuntos variados que eram trazidos à sua consideração, congregando atores individuais e coletivos na defesa dos princípios do SUS e procurando tornar-se o principal espaço de articulação de conselheiros estaduais e municipais visando a fortalecer a cadeia de mecanismos de participação do sistema, na qual o Conselho ocupava a posição superior. Ele era também um dos lugares centrais de conexão entre participantes importantes da rede da política de saúde, em especial da nova comunidade de política que se formara no final dos anos 90.

\section{REFERÊNCIAS}

BRASIL. Lei n. 8.080, de 19 de setembro de 1990. Dispõe sobre as condições para a promoção, proteção e recuperação da saúde, a organização e o funcionamento dos serviços correspondentes e dá outras providências.

BRASIL. Conselho Nacional de Saúde. Resolução n. 52, de 6 de maio de 1993. Institui a Mesa Nacional de Negociação.

BRASIL. Conselho Nacional de Saúde. Resolução n. 229, de 8 de maio de 1997. Reinstala a Mesa Nacional de Negociação, com os objetivos da resolução CNS n. 52/93.

BRASIL. Conselho Nacional de Saúde. Resolução n. 291, de 6 de maio de 1999. Dispõe sobre as instâncias internas do Conselho.

BRASIL. Conselho Nacional de Saúde. Resolução n. 331, de 4 de novembro de 2003a. Ratifica o ato de reinstalação da Mesa Nacional de Negociação Permanente do SUS (MNNP-SUS).

BRASIL. Conselho Nacional de Saúde. Decreto 4.878, de 18 de novembro de 2003b. Dispõe sobre a composição do Conselho Nacional de Saúde (CNS) e dá outras providências.

BRASIL. Conselho Nacional de Saúde. Atas de reunião. Disponíveis em: <http:// conselho.saude.gov.br/atas/atas_08.htm>. Acesso em: jun.-dez. 2005.

COHEN, J. L. Sociedade civil e globalização: repensando categorias. Dados - Revista de Ciências Sociais, 46(3): 419-459, 2003.

CÔRTES, S. M. V. Pautas de reuniões e participação de usuários em conselho municipal de saúde. In: CONGRESSO BRASILEIRO DE CIÊNCIAS SOCIAIS EM SAÚDE, 2, 1999, São Paulo. Anais... São Paulo: Abrasco, 1999. 
JORDAN, G. \& RICHARDSON, J. J. Governing under Pressure. Oxford: Martin Robertson, 1979.

LEVCOVITZ, E.; LIMA, L. D.; \& MACHADO, C. V. Política de saúde nos anos 90: relações intergovernamentais e o papel das normas operacionais básicas. Ciência $\mathbb{E}$ Saúde Coletiva, 6(2): 269-291, 2001.

MAGNI, C. T. Diário de Campo. Conselho Nacional de Saúde, out. 2005. Arquivos PPGS/UFRGS. CD-ROM.

RODES, R. A. W. The National World of Local Government. Oxford: Allen and Unwin, 1986.

\section{ENTREVISTAS}

A. H. Entrevista realizada em 11 de abril de 2006. Porto Alegre. Transcrita. Arquivos GPPS/UFRGS.

G. S. Entrevista realizada em 4 de maio de 2006. Rio de Janeiro. Transcrita. Arquivos GPPS/UFRGS.

H. A. Entrevista realizada em 5 de maio de 2006. Rio de Janeiro. Transcrita. Arquivos GPPS/UFRGS.

I. E. Entrevista realizada em 23 de maio de 2006. Florianópolis. Transcrita. Arquivos GPPS/UFRGS.

J. R. Entrevista realizada em 31 de maio de 2006. Brasília. Transcrita. Arquivos GPPS/ UFRGS.

K. L. Entrevista realizada em 13 de junho de 2006. Porto Alegre. Transcrita. Arquivos GPPS/UFRGS.

L. M. Entrevista realizada em 16 de janeiro de 2006. Porto Alegre. Transcrita. Arquivos GPPS/UFRGS.

M. C. Entrevista realizada em 23 de maio de 2006. Florianópolis. Transcrita. Arquivos GPPS/UFRGS.

N. G. Entrevista realizada em 31 de maio de 2006. Brasília. Transcrita. Arquivos GPPS/UFRGS.

O. G. Entrevista realizada em 22 de maio de 2006. Uberlândia. Transcrita. Arquivos GPPS/UFRGS.

P. G. Entrevista realizada em 31 de maio de 2006. Brasília. Transcrita. Arquivos GPPS/ UFRGS.

Q. F. Entrevista realizada em 2 de junho de 2006. Brasília. Transcrita. Arquivos GPPS/ UFRGS.

R. C. Entrevista realizada em 11 de julho de 2006. Brasília. Transcrita. Arquivos GPPS/ UFRGS.

V. N. Entrevista realizada em 1o de setembro de 2006. Florianópolis. Transcrita. Arquivos GPPS/UFRGS.

W. J. Entrevista realizada em 20 de setembro de 2006. Florianópolis. Transcrita. Arquivos GPPS/UFRGS. 


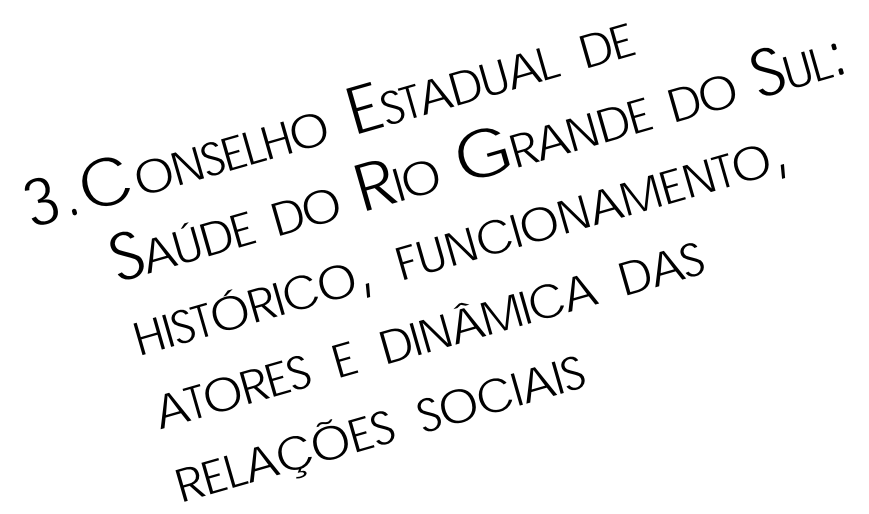

Elisabete Oliveira Pereira

Soraya Vargas Côrtes

Márcio Barcelos

\begin{abstract}
Analisar a dinâmica das relações sociais no interior do Conselho Estadual de Saúde do Rio Grande do Sul (CES/RS) ${ }^{1}$ e a posição desse fórum na configuração das relações sociais da área da saúde no estado são os principais objetivos deste capítulo. Um propósito secundário foi comparar as dinâmicas sociais no Conselho Nacional e no CES/RS e nas arenas decisórias da área da saúde em níveis federal e estadual. $\mathrm{O}$ uso do método comparativo tem a vantagem de ressaltar aspectos relevantes para análise de processos sociais e políticos porque acentua recorrências e destaca peculiaridades inesperadas, considerando as dimensões tratadas como fundamentais em determinada investigação (Sartori, 1994).

O caso do CES/RS foi escolhido por duas razões fundamentais. Em primeiro lugar, vários estudos revelam a existência de padrões altos de associativismo e interesse por política não apenas em diversos municípios do estado (IBGE, 1996; Avritzer, 2002; Baierle, 1992; Silva, 2001) como

\footnotetext{
${ }^{1}$ Para a elaboração deste capitulo foram utilizados os resultados de duas investigações feitas pelo Grupo de Pesquisa Sociedade, Participação Social e Politicas Sociais da Universidade Federal do Rio Grande do Sul (GPPS/UFRGS). A primeira teve como objetivo principal a elaboração de dissertação de mestrado, defendida no Programa de Pós-Graduação em Sociologia da UFRGS (Pereira, 2006), que analisou a participação de usuários no CES/RS entre 1999 e 2002. A segunda pesquisa foi realizada com a finalidade de obter dados complementares que permitissem responder às perguntas orientadoras do presente trabalho.
} 
também em suas regiões (Côrtes, 2003; Bandeira, 1999). Em segundo lugar, o CES/RS era apresentado nos debates do CNS como uma espécie de modelo de funcionamento 'democrático', uma vez que desde sua criação o presidente do fórum era eleito entre seus membros titulares. A conjugação desses fatores - cultura cívica e associativa relativamente consistente e indícios de que o fórum funcionava com relativa autonomia em relação ao gestor estadual de saúde - permite supor que o Conselho tinha condições institucionais e políticas favoráveis para desempenhar papel relevante no contexto da área da saúde do estado.

Os participantes envolvidos nas atividades do Conselho e na arena decisória da área foram classificados em três tipos de atores: governamentais, de mercado e sociais. A tipologia é inspirada na concepção de Cohen (2003: 427), segundo a qual

setores decisórios no âmbito do Estado sofrem restrições formais e temporais (...); na empresa privada, os decisores econômicos (...) não podem se furtar aos imperativos do lucro e da produtividade. (...) Já na sociedade civil, os atores não visam à conquista do poder do Estado ou à organização da produção; em vez disso, tentam exercer influência pela participação em associações e movimentos democráticos e por meio da mídia pública.

Por isso o sentido que esses atores atribuem às suas ações políticas seria guiado por tais imperativos. Assim, mesmo sem assumir a noção de que haveria uma positividade inerente à sociedade civil e seus atores, tratam-se aqui a sociedade civil e seus atores como diferentes do Estado e do mercado, e de seus atores.

As principais fontes de informação foram atas e listas de presenças de reuniões plenárias do Conselho, documentos legais e administrativos obtidos na Secretaria Executiva do fórum e entrevistas com dez conselheiros e exconselheiros. ${ }^{2}$ Analisaram-se as atas de 38 reuniões plenárias do CES/RS,

\footnotetext{
2 Foram realizadas dez entrevistas: nove entre abril de 2006 e setembro de 2006, e uma em abril de 2007. Foram entrevistados: 1) seis conselheiros e ex-conselheiros que representavam organizações da sociedade civil - um de organização religiosa; um de entidades de profissionais e trabalhadores de saúde; um de entidades étnicas, de gênero e de portadores de patologias ou deficiências; um de associações comunitárias, movimentos sociais e organizações não governamentais (ONGs); e dois de entidades de trabalhadores, não especificamente da área da saúde; 2) um conselheiro que representava entidades de mercado - de entidade estadual de prestadores de serviços de saúde; e 3) três conselheiros e ex-conselheiros que representavam órgãos governamentais - dois gestores de saúde estaduais e um municipal.
} 
que compuseram uma amostra construída por processo de amostragem aleatória simples, ${ }^{3}$ com base em um universo de 84 atas das reuniões realizadas entre 1999 e 2002 . Foram também examinadas as listas de presenças das 63 reuniões que ocorreram em 2000, 2001 e 2002, pois não foi possível obter as listas dos presentes da maior parte das reuniões em 1999. ${ }^{4}$ Tal análise ofereceu indicações sobre quais atores participaram do Conselho e sobre aqueles que mais influenciaram nas deliberações e decisões do fórum. Permitiu ainda identificar os temas discutidos com maior freqüência e caracterizar o papel do fórum no contexto da política de saúde estadual. Os documentos legais e administrativos que tratam do Conselho auxiliaram na reconstituição de seu histórico e estrutura de funcionamento. As entrevistas contribuíram para esclarecer questões relacionadas ao posicionamento dos conselheiros e aos principais assuntos tratados no período.

Inicialmente, o capítulo apresenta um histórico do CES/RS e descreve sua estrutura de funcionamento. Em seguida, por meio da análise das reuniões plenárias, examina a dinâmica das relações entre os atores envolvidos em suas atividades, assim como a desses atores e do próprio fórum com os demais atores e instituições que compunham a rede da política de saúde no estado.

\section{Conselho Estadual de SAÚde/RS: HISTÓRICO, ESTRUTURA DE APOIO E ATUAÇÃO DOS CONSEUHEIROS}

O CES/RS foi criado em 1994 (Rio Grande do Sul, 1994), logo após o estabelecimento de convênio de estadualização entre os governos federal e estadual no âmbito da implantação da norma operacional básica (NOB) n. 01/93 (Brasil, 1993) no estado. Na verdade, houve a transformação em conselho da Comissão Interinstitucional de Saúde (CIS), que fora constituída em 1987, com a implementação do Sistema Unificado Descentralizado de Saúde (Suds). Seguindo as normas federais (Brasil, 1990), a lei de criação do novo fórum (Rio Grande do Sul, 1994, art. 20) o estabeleceu

\footnotetext{
${ }^{3}$ A amostragem aleatória consiste na seleção das unidades amostrais em que cada uma tem iguais possibilidades de seleção. No caso, cada ata do periodo foi tratada como uma unidade amostral. O tamanho da amostra foi definido utilizando-se como parâmetro um intervalo de confiança de $90 \%$, considerando-se um erro relativo máximo de $10 \%$.

${ }^{4}$ Foram examinadas 63 listas de presenças: 19 de 2000 (em 2000, ocorreram vinte reuniões, mas apenas 19 listas de presenças estavam disponiveis), 22 de 2001 e 22 de 2002.
} 
como instância colegiada do Sistema Único de Saúde (SUS), com funções deliberativas, normativas e fiscalizadoras. As principais competências do CES/RS estão relacionadas: à fixação de critérios e diretrizes para o estabelecimento de políticas, programas, contratos e convênios; à avaliação, ao acompanhamento, controle e fiscalização de serviços de saúde e da execução da política e do orçamento na área (Rio Grande do Sul, 1994, art. 8). A lei estabelece ainda que, em relação ao controle social, o fórum é responsável pela formulação de diretrizes e instruções para a formação e o desenvolvimento de conselhos regionais, municipais e locais de saúde e a organização das Conferências Estaduais de Saúde.

Desde 1999, o CES/RS estava localizado no Centro Administrativo do Governo do Estado, abrangendo um espaço físico de aproximadamente quatrocentos metros quadrados, que acomodava salas de apoio e a sala onde se realizavam as reuniões plenárias. Seu funcionamento era regulado por Regimento Interno, ${ }^{5}$ o qual estabelecia como suas principais instâncias: Mesa Diretora, Secretaria Executiva, Assessoria Técnica, Comissão de Fiscalização, Comissões Temáticas e Especiais e Plenário.

À Mesa Diretora competia convocar e dirigir as reuniões plenárias, organizar a pauta de discussões e coordenar o funcionamento técnico e administrativo do CES/RS. Era composta por três representantes de usuários, um do gestor estadual, um de prestadores de serviços e um de profissionais e trabalhadores de saúde, todos eleitos diretamente pelo Plenário, em votação aberta, para um exercício de dois anos. Concomitantemente, elegiam-se, dentre os seis, um presidente e um vice-presidente. No período estudado, ela se reunia quinzenalmente.

Conselheiros provenientes de entidades sociais têm predominado no exercício da presidência da Mesa Diretora do CES/RS. Além de presidirem o fórum por 12 anos, em um total de 14 (1994 a 2007), eles exerceram sete mandatos, em um total de oito. Dos sete mandatos, cinco couberam a representantes de entidades de profissionais e trabalhadores da saúde, dos quais três foram exercidos pela mesma pessoa. Assim como no CNS, no CES/RS essa categoria de conselheiros - e provavelmente um pequeno grupo de seus representantes - exercia grande influência sobre os trabalhos do fórum (Quadro 1).

\footnotetext{
${ }^{5}$ As informações sobre o funcionamento e a organização do CES/RS baseiam-se principalmente no Regimento Interno publicado no Diário Oficial do Estado em 6 de maio de 1994 e em informações obtidas no Conselho em 2003 e 2007.
} 
Quadro 1 - Presidentes da Mesa Diretora, por tipo e categoria de representante e segundo entidade representada. CES/RS - 1994-2007

\begin{tabular}{|c|c|c|c|}
\hline Período & $\begin{array}{l}\text { Tipo de } \\
\text { representante }\end{array}$ & Categoria de conselheiro & Entidade \\
\hline 1994-1996 & Social & $\begin{array}{l}\text { Profissionais e trabalhadores de } \\
\text { saúde }\end{array}$ & $\begin{array}{l}\text { Sindicato dos Servidores Públicos do } \\
\text { Estado do Rio Grande do Sul }\end{array}$ \\
\hline 1996-1997 & Governamental & Governo, não saúde & Secretaria Estadual de Educação* \\
\hline $1997-1998$ & Social & $\begin{array}{l}\text { Profissionais e trabalhadores de } \\
\text { saúde }\end{array}$ & $\begin{array}{l}\text { Sindicato dos Servidores Públicos do } \\
\text { Estado do Rio Grande do Sul }\end{array}$ \\
\hline $1998-2000$ & Social & $\begin{array}{l}\text { Profissionais e trabalhadores de } \\
\text { saúde }\end{array}$ & $\begin{array}{l}\text { Sindicato dos Servidores Públicos do } \\
\text { Estado do Rio Grande do Sul }\end{array}$ \\
\hline $2000-2002$ & Social & $\begin{array}{l}\text { Profissionais e trabalhadores de } \\
\text { saúde }\end{array}$ & $\begin{array}{l}\text { Sindicato dos Servidores Públicos do } \\
\text { Estado do Rio Grande do Sul }\end{array}$ \\
\hline $2002-2004$ & Social & $\begin{array}{l}\text { Profissionais e trabalhadores de } \\
\text { saúde }\end{array}$ & Sindicato dos Psicólogos \\
\hline $2004-2006$ & Social & Trabalhadores, não saúde & $\begin{array}{c}\text { Conselho Regional de Saúde (11a Região) } \\
\text { Central Única dos Trabalhadores } \\
\text { (CUT) }\end{array}$ \\
\hline $2006-2007$ & Social & Igrejas & $\begin{array}{c}\text { Conferência Nacional dos Bispos do } \\
\text { Brasil (CNBB) }\end{array}$ \\
\hline
\end{tabular}

* O presidente eleito, representante da Secretaria Estadual de Educação, exerceu o mandato por apenas um ano, sendo substituido em 1997 pelo vice-presidente eleito, um profissional de saúde, funcionário da Secretaria Estadual de Saúde (SES), representante do Sindicato dos Servidores Públicos do Estado do Rio Grande do Sul.

Fonte: Rio Grande do Sul, 2007a.

À Secretaria Executiva cabia a organização das tarefas cotidianas do fórum e a execução de atividades técnicas e administrativas de apoio à Mesa Diretora, ao Plenário e às comissões. Até 1999, a Secretaria funcionava em uma sala de aproximadamente trinta metros quadrados, situada no quinto andar do Centro Administrativo do Governo do Estado. A partir de então, passou a ocupar um complexo de seis salas, com uma área de aproximadamente quatrocentos metros quadrados no vigésimo andar do mesmo Centro Administrativo. No local, ocorriam também as reuniões plenárias. Em 2003, um servidor público estadual e três estagiários estavam à disposição da Secretaria para o apoio às atividades do Conselho.

A Assessoria Técnica reunia-se apenas quando tramitavam no Conselho assuntos que requeriam a emissão de pareceres técnicos. Ela tinha cará- 
ter permanente, e sua principal tarefa era assessorar a tomada de decisões do Plenário por meio da realização de estudos - nas áreas jurídica, política e orçamentária - e da subseqüente elaboração de pareceres. Seus integrantes eram funcionários públicos estaduais, com formação especializada nas áreas jurídica e orçamentária. Em 2003, três funcionários públicos estaduais compunham a assessoria técnica do Conselho.

A Comissão de Fiscalização, também de caráter permanente, realizava reuniões semanais. Suas atividades concentravam-se na fiscalização das ações e dos serviços prestados pelo SUS. Essa comissão tinha seis membros, todos conselheiros (Rio Grande do Sul, 1994, art. 22), escolhidos conforme a regra de paridade que fixava que a metade dos participantes deveria representar usuários e a outra metade deveria ser composta por representantes do gestor estadual, de prestadores de serviços e de profissionais e trabalhadores de saúde. No entanto, em 2003, compareciam às reuniões da comissão apenas quatro conselheiros, e entre eles não havia representantes governamentais (gestor estadual) ou de mercado (prestadores de serviços). Atuavam de fato na comissão quatro conselheiros: um proveniente de entidade de trabalhadores e profissionais da saúde; um de organizações de trabalhadores, não especificamente da área da saúde; um de entidade religiosa; e um de associações comunitárias e movimentos sociais. A coordenação da comissão era exercida pelo conselheiro proveniente de organização de trabalhadores e profissionais de saúde. A predominância de conselheiros oriundos de entidades sociais na comissão é mais uma indicação de sua importância no processo decisório que ocorria no CRS/RS (Quadro 2).

As Comissões Temáticas e Especiais tinham caráter temporário. Eram criadas no intuito de subsidiar o processo de tomada de decisões, quando o Plenário assim decidia. Em 2003, sete comissões estavam em atividade. ${ }^{6}$ A duração de suas atividades era indefinida, variava em razão da relevância do tema, da urgência para que o Plenário decidisse sobre certo assunto ou enquanto o Plenário considerasse necessário aprofundar a análise de determinada questão. A comissão organizada para discutir a criação de conselhos gestores em hospitais, por exemplo, permaneceu em atividade enquanto a questão era debatida pelo Plenário. Já uma comissão de acompanhamento

\footnotetext{
${ }^{6}$ Em 2003, as comissões em atividade eram as seguintes: Acompanhamento ao Processo Orçamentário, Saúde do Trabalhador, Conselhos Regionais de Saúde, Saúde Mental, DST/Aids, Saúde da Mulher e Assistência Complementar à Saúde (Pereira, 2006).
} 
do processo orçamentário era instituída toda vez que o Plenário precisava analisar planos de aplicação e prestações de contas.

Quadro 2 - Composição da Comissão de Fiscalização, por tipo e categoria de representante e segundo entidade representada. CES/RS - 2003

\begin{tabular}{|c|c|c|}
\hline $\begin{array}{c}\text { Tipo de } \\
\text { representante }\end{array}$ & Categoria de conselheiro & Entidade \\
\hline Social & $\begin{array}{c}\text { Profissionais e trabalhadores de } \\
\text { saúde }\end{array}$ & $\begin{array}{c}\text { Sindicato dos Servidores Públicos do Estado } \\
\text { do Rio Grande do Sul }\end{array}$ \\
\hline Social & Trabalhadores, não saúde & $\begin{array}{c}\text { Conselho Regional de Saúde (11a Região) - } \\
\text { Central Única dos Trabalhadores (CUT) }\end{array}$ \\
\hline Social & Igrejas & $\begin{array}{c}\text { Conferência Nacional dos Bispos do Brasil } \\
\text { (CNBB) }\end{array}$ \\
\hline Social & $\begin{array}{c}\text { Associações comunitárias, } \\
\text { movimentos sociais e organizações } \\
\text { não governamentais (ONGs) }\end{array}$ & $\begin{array}{c}\text { Federação Riograndense de Associações } \\
\text { Comunitárias e de Moradores de Bairro } \\
\text { (Fracab) }\end{array}$ \\
\hline
\end{tabular}

Fonte: Rio Grande do Sul, 2007b.

O Plenário era a instância máxima de deliberação do CES/RS (Rio

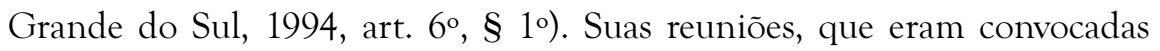
pela Mesa Diretora, realizavam-se à tarde, em geral das $14 \mathrm{~h}$ às $18 \mathrm{~h}$. Eram coordenadas pelo presidente da Mesa Diretora do Conselho e, em caso de ausência, pelo vice-presidente ou outro integrante da Mesa Diretora. Embora a ordem de discussão dos assuntos pudesse ser modificada pelo Plenário, o roteiro básico das reuniões era o seguinte: 1) abertura e verificação do número de conselheiros presentes com direito a voto; 2) leitura e aprovação da ata da reunião anterior; 3) leitura do expediente, comunicações, requerimentos, moções, indicações e proposições; 4) distribuição de processos e/ou expedientes, entre os conselheiros, para elaboração de pareceres; 5) discussão e deliberação dos pontos de pauta; 6) indicação da agenda da reunião subseqüente; 7) assuntos gerais.

Cabia à Mesa Diretora informar a agenda de discussões com antecedência mínima de cinco dias úteis da respectiva reunião plenária. No entanto, o Plenário podia deliberar que outro assunto fosse incluído na pauta, desde que se justificasse a urgência ou relevância da matéria (Rio Grande do Sul, 1994, art. 33). 
O Quadro 3 mostra a composição do Plenário, que foi definida pela lei n. 10.097/94 (Rio Grande do Sul, 1994) e permaneceu sem alterações desde a criação do Conselho. Por essa razão, secretarias estaduais que mudaram de designação e função, segundo reformulações governamentais na estrutura organizacional das pastas, ou mesmo organizações sociais que deixaram de existir permaneceram na composição do CES/RS. ${ }^{7}$

A lei (Rio Grande do Sul, 1994, art. 4º) não especificou que entidades de profissionais da área da saúde teriam assento no fórum; ela apenas designou as categorias que o integrariam. Ficou, portanto, a critério do conjunto das entidades de cada categoria profissional designada deliberar e indicar qual delas o representaria. Desde a criação do fórum, os médicos, enfermeiros e psicólogos têm sido representados pelos sindicatos das categorias. Os odontólogos, veterinários, farmacêuticos-bioquímicos, nutricionistas, assistentes sociais, fisioterapeutas e terapeutas ocupacionais indicaram representantes dos respectivos conselhos regionais. Já as organizações de trabalhadores de saúde - as quais congregavam, na mesma entidade, trabalhadores de nível de escolaridade superior, médio e fundamental - que integravam Conselho foram definidas pela lei (Federação dos Empregados em Estabelecimentos de Serviços de Saúde no Estado do Rio Grande do Sul - Feessers; Sindicato dos Servidores Públicos do Estado do Rio Grande do Sul - Sindsepe RS).

À exceção do Fórum de Saúde Mental, as demais organizações de portadores de patologias e deficiências e de defesa do consumidor que tinham assento no Conselho não foram denominadas pela lei (Rio Grande do Sul, 1994, art. 4º). Além do referido fórum, representavam os portadores de patologias e deficiências o Grupo de Apoio à Prevenção à Aids (Gapa), a Associação Gaúcha de Familiares de Pacientes Esquizofrênicos e demais Doenças Mentais (Agafape) e a Fraternidade Cristã de Doentes e Deficientes; as entidades de defesa do consumidor eram representadas pela Associação de Defesa do Consumidor de Vacaria (Adecov).

Os representantes dos conselhos regionais, em geral, eram ativistas do movimento de trabalhadores rurais. Por isso eles foram classificados na categoria de trabalhadores, não especificamente da área da saúde (Quadro 3).

\footnotetext{
${ }^{7}$ Esse foi o caso da antiga Secretaria da Saúde e do Meio Ambiente, que passou a ser designada como Secretaria Estadual de Saúde; da Secretaria de Planejamento e Administração, que deixou de existir e foi substituida no Conselho pela Secretaria de Coordenação e Planejamento; e da antiga Secretaria da Justiça, do Trabalho e Cidadania, que foi transformada em Secretaria do Trabalho, Cidadania e Assistência Social. No âmbito das organizações não governamentais, a entidade Ação Democrática Feminina Gaúcha - Amigos da Terra - em 2003 não existia mais, porém permanecia com um assento no CES/RS.
} 


\section{Quadro 3 - Composição do CES/RS, por tipo de representante e entidade ou categoria representada - 1994}

\begin{tabular}{|c|c|c|}
\hline \multirow{2}{*}{ 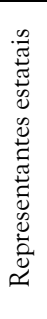 } & \multirow[t]{2}{*}{ Governamentais } & $\begin{array}{l}\text { - Secretaria da Saúde e do Meio Ambiente (três representantes) } \\
\text { - Coordenadoria de Cooperação e Apoio Técnico do Ministério da Saúde } \\
\text { - Associação dos Secretários e Dirigentes Municipais de Saúde (Assedisa) } \\
\text { - Federação das Associações de Municípios do Estado do Rio Grande do Sul(Famurs) }\end{array}$ \\
\hline & & $\begin{array}{l}\text { - Secretaria de Planejamento e Administração } \\
\text { - Secretaria da Justiça, do Trabalho e Cidadania } \\
\text { - Secretaria Estadual de Educação } \\
\text { - Companhia Riograndense de Saneamento (Corsan) } \\
\text { - Universidade Federal do Rio Grande do Sul (UFRGS) } \\
\text { - Associação Riograndense de Empreendimentos de Assistência Técnica e Extensão Rural } \\
\text { (Emater) }^{*}\end{array}$ \\
\hline \multirow{7}{*}{ 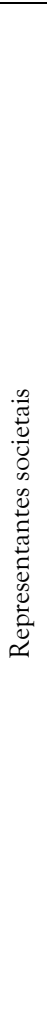 } & $\begin{array}{l}\text { Prestadores privados de } \\
\text { serviços de saúde }\end{array}$ & $\begin{array}{l}\text { - Federação das Santas Casas e Hospitais Filantrópicos do Rio Grande do Sul ** } \\
\text { - Associação dos Hospitais do Rio Grande do Sul } \\
\text { - Associação Gaúcha de Entidades Prestadoras de Serviços de Saúde Ambulatoriais (Agepssa) } \\
\text { - Sindicato dos Laboratórios }\end{array}$ \\
\hline & $\begin{array}{l}\text { Profissionais e } \\
\text { trabalhadores de saúde }\end{array}$ & $\begin{array}{l}\text { - Entidade dos médicos } \\
\text { - Entidade dos odontólogos } \\
\text { - Entidade dos enfermeiros } \\
\text { - Entidade dos nutricionistas } \\
\text { - Entidade dos assistentes sociais } \\
\text { - Entidade dos psicólogos } \\
\text { - Entidade dos farmacêuticos-bioquímicos } \\
\text { - Entidade dos veterinários } \\
\text { - Entidade dos fisioterapeutas e terapeutas ocupacionais } \\
\text { - Federação dos Empregados em Estabelecimentos de Saúde no Estado do Rio Grande do Sul } \\
\text { (Feessers) } \\
\text { - Sindicato dos Servidores Públicos do Estado do Rio Grande do Sul(Sindsepe RS) (sempre } \\
\text { trabalhadores da área da saúde) }\end{array}$ \\
\hline & Empresários & $\begin{array}{l}\text { - Federação das Indústrias do Estado do Rio Grande do Sul(Fiergs) } \\
\text { - Federação das Associações Comerciaise de Serviços do Rio Grande do Sul (Federasul) } \\
\text { - Federação da Agricultura do Estado do Rio Grande do Sul (Farsul) }\end{array}$ \\
\hline & $\begin{array}{l}\text { Trabalhadores (não } \\
\text { saúde) }\end{array}$ & $\begin{array}{l}\text { - Central Única dos Trabalhadores/RS (CUT/RS) (dois representantes) } \\
\text { - Central Geral dos Trabalhadores/RS (CGT/RS) (dois representantes) } \\
\text { - Federação dos Trabalhadores na Agricultura no Rio Grande do Sul(Fetag/RS) (dois } \\
\text { representantes) } \\
\text { - Conselhos Regionais de Saúde (CRS) (cinco representantes, sempre usuários) }\end{array}$ \\
\hline & $\begin{array}{l}\text { Associações comunitárias, } \\
\text { movimentos sociais e } \\
\text { ONGs }\end{array}$ & $\begin{array}{l}\text { - Federação Riograndense de Associações Comunitárias e de Moradores de Bairro (Fracab)(dois } \\
\text { representantes) } \\
\text { - Federação dos Trabalhadores Aposentados e Pensionistas doRio Grande do Sul(Fetapergs) } \\
\text { - Associação Gaúcha de Proteção ao Ambiente Natural (Agapan) } \\
\text { - Ação Democrática Feminina Gaúcha (ADFG) - Amigos da Terra } \\
\text { - Representação das entidades de defesa do consumidor }\end{array}$ \\
\hline & $\begin{array}{l}\text { Entidades de portadores } \\
\text { de patologias e } \\
\text { deficiências }\end{array}$ & $\begin{array}{l}\text { - Entidades de portadores de patologias (dois representantes) } \\
\text { - Entidades de portadores de deficiências } \\
\text { - Fórum Gaúcho de Saúde Mental }\end{array}$ \\
\hline & Igrejas & - Conferência Nacional dos Bispos do Brasil (CNBB) \\
\hline
\end{tabular}

* Embora a Emater seja uma entidade privada, como seu financiamento é predominantemente público, os governos estaduais definem seus dirigentes e influem fortemente sobre a definição de suas estratégias e ações. Por isso foi incluida entre os atores governamentais.

** A lei estadual n. 10.097 (Rio Grande do Sul, 1994, art. 4º) denomina a entidade como 'Federação das Misericórdias RS'.

${ }^{* * *} \mathrm{Na}$ lei n. 10.097 (Rio Grande do Sul, 1994, art. 4) consta a 'Federação dos Empregados em Estabelecimentos de Saúde no Estado do Rio Grande do Sul'. Em 1998, uma reforma estatutária mudou o nome da entidade, que passou a ser denominada 'Federação dos Empregados em Serviços de Saúde do Estado do Rio Grande do Sul'. Mas a lei n. 10.097, com o nome antigo da federação, continua em vigor.

Fonte: Rio Grande do Sul, 1994, art. 4º. 
A maioria dos conselheiros era proveniente de organizações sociais (Gráfico 1). Eles perfaziam 63\% (33 em 52) do total de integrantes do CES/RS. Dentre eles, a maior parte (22 em 33) era de representantes de entidades de profissionais e trabalhadores de saúde (11) e de trabalhadores não especificamente da área da saúde (11). Apenas 13\% (sete em 52) dos conselheiros representavam entidades de mercado, dentre os quais predominavam os conselheiros oriundos de organizações de prestadores privados de serviços de saúde (quatro em sete).

A predominância de representantes de organizações sociais coincide com o padrão encontrado no CNS, em 1994 (Brasil, 1994, art. 1). O Gráfico 1 mostra que, em 1994, ano de criação do CES/RS, essa predominância era mais acentuada no Conselho Estadual. Enquanto neste eles compunham 63\% do total do Plenário (33 em 52), no Conselho Nacional correspondiam a $49 \%$ do total de conselheiros (17 em 35). Em contrapartida, havia, proporcionalmente e em números absolutos, mais representantes de órgãos governamentais no CNS (37\% - 13 em 35) do que no CES/RS (23\% - 12 em 52). Já os representantes de entidades de mercado tinham praticamente a mesma, e pequena, proporção de representantes em ambos os conselhos (14\% - cinco em 35 - no CNS; e 13\% - sete em 52 - no CES/RS).

Gráfico 1 - Número e percentual de conselheiros, por tipo de representante: de mercado, governamentais e sociais. CNS, CES/RS - 1994

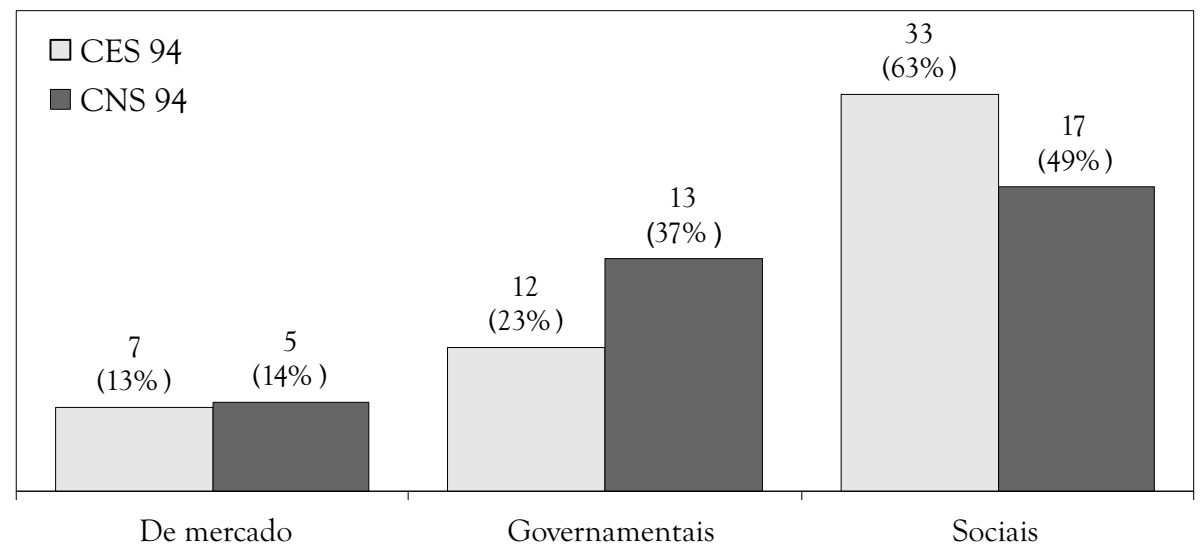

Fonte: Rio Grande do Sul, 1994, art, 4º; Brasil, 1994, art. 1º.

Observe-se que existe contraste entre as proporções de representantes governamentais e de entidades sociais verificadas nos dois conselhos. Ele se deve, principalmente, ao fato de o CES/RS apresentar menor proporção de 
representantes governamentais e de entidades étnicas, de gênero e de portadores de patologias ou deficiências, e maior participação de conselheiros provenientes de entidades de trabalhadores, não especificamente da área da saúde, e de profissionais e trabalhadores de saúde. Observe-se que, entre 1994 e 2006, enquanto no CNS ocorreram várias alterações na composição oficial do Plenário, no CES/RS não houve uma modificação sequer (Gráfico 2). ${ }^{8}$

Gráfico 2 - Número e percentual de conselheiros segundo a categoria de representantes. CNS, CES/RS - 1994

Governamentais + indicados

Trabalhadores (não saúde)

Profissionais, trabalhadores de saúde

Associações comunitárias, movimentos sociais, ONGs

Entidades étnicas, de gênero e de portadores de patologias ou deficiências

Prestadores privados de serviços de saúde

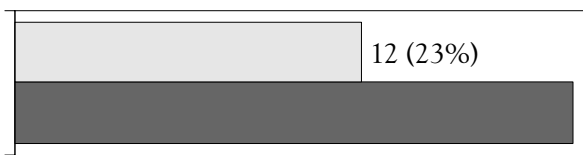

\section{(1)}
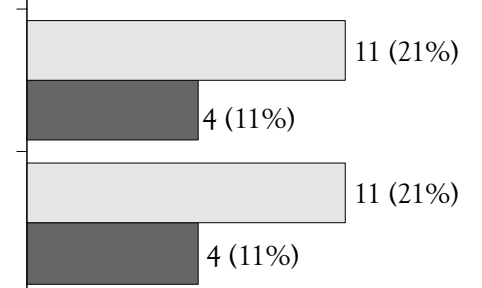

Empresários

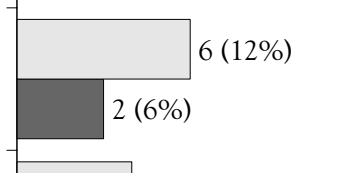
$6(17 \%)$

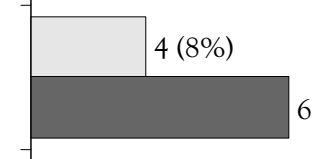

Igrejas

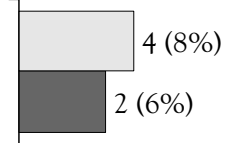

$3(6 \%)$

$3(9 \%)$

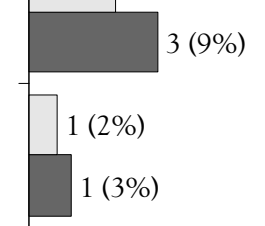

CNS 1994

Fonte: Rio Grande do Sul, 1994, art. 4º Brasil, 1994, art. $1^{\circ}$.

\footnotetext{
${ }^{8}$ Entre 1994 e 2006, no CNS diminuiu a proporção de representantes de instituições governamentais (em 1994: 37\% - 13 em 35; em 2006: 17\% - oito em 48) e de trabalhadores, não especificamente da área da saúde (em 1994: 11\% - quatro em 35; em 2006: 6\% - três em 48). No mesmo período, aumentou o percentual de representantes de entidades étnicas, de gênero e de portadores de patologias ou deficiências (em 1994: 17\% - seis em 35; em 2006: 27\% - 13 em 48) e de profissionais trabalhadores de saúde (em 1994: 11\% - quatro em 35; em 2006: 25\% - 12 em 48) (Brasil, 1994, art. 1\%; Brasil, 2006a).
} 
$O$ alto percentual de representantes de entidades de profissionais e trabalhadores de saúde e de trabalhadores, não especificamente da área da saúde, na composição legal dos plenários é um indicativo da capacidade dessas categorias de participantes de influenciarem as decisões do fórum. Mas as indicações são de que a posição, no interior do CES/RS, dos representantes de entidades de profissionais e trabalhadores de saúde no contexto do fórum era a mais destacada. Em 2003, eles coordenavam a Comissão de Fiscalização e grande parte das reuniões plenárias, e na maior parte do tempo, ao longo do período de existência do fórum, exerceram a presidência da Mesa Diretora.

A essas indicações de sua predominância no processo decisório do fórum somava-se o fato de esses representantes serem os mais assíduos às reuniões plenárias e os que mais participavam dos debates do fórum. A Tabela 1 mostra que a proporção total de conselheiros presentes às reuniões em 2000, 2001 e 2002, considerando o tipo de representação, corresponde àquela prevista pela lei que instituiu o CES/RS (Gráfico 1), qual seja: 63\% dos conselheiros provinham de entidades sociais, 23\% de órgãos governamentais e $13 \%$ de organizações de mercado. A diferença está na assiduidade de cada um: enquanto 11 dos 14 conselheiros mais assíduos (79\%) - que compareceram a mais de 42 reuniões - eram provenientes de entidades sociais, apenas dois (14\%) e um (7\%) eram representantes, respectivamente, governamentais ou de organizações de mercado.

$\bigcirc$ único conselheiro proveniente de entidades de mercado muito assíduo às reuniões - presente a 57 das 63 reuniões examinadas - representava prestadores de serviços de saúde por meio da Federação das Santas Casas e Hospitais Filantrópicos do Rio Grande do Sul. Tal fato está provavelmente relacionado à importância que o financiamento do SUS assumia para os hospitais filiados à Federação. Em 2000, o SUS financiou 797 mil internações no Rio Grande do Sul; destas, 482 mil (60\%) foram realizadas em hospitais filantrópicos (Pacheco, 2007). À entidade interessava participar nos debates que o Conselho realizava sobre o sistema, especialmente no que tange ao financiamento. Por isso, também a atenção do representante de hospitais filantrópicos no fórum foi galvanizada pela discussão em torno de dois projetos propostos pelos gestores estaduais de saúde: a constituição do Fundo de Apoio Financeiro e de Recuperação dos Hospitais Privados sem Fins Lucrativos e Hospitais Públicos no Estado do Rio Grande do Sul (Funafir) (Rio Grande do Sul, 1999a) e a criação de conselhos gestores em hospitais credenciados pelo SUS. 
Tabela 1 - Número e percentual de conselheiros por número de reuniões a que compareceram, segundo os tipos de conselheiros: de mercado, governamentais e sociais. CES/RS, 2000, 2001 e 2002*

\begin{tabular}{|c|c|c|c|c|c|c|c|c|c|c|c|}
\hline Número de & iões & $0 \mathrm{a}$ & & 11 & & 24 & & $42 \mathrm{o}$ & mais & & \\
\hline Tipos de con & iros & No & $\%$ & No & $\%$ & No & $\%$ & No & $\%$ & No & $\%$ \\
\hline & No & 2 & $40 \%$ & 2 & $40 \%$ & - & & 1 & $20 \%$ & 5 & $100 \%$ \\
\hline De mercado & $\%$ & $3 \%$ & & $9 \%$ & & - & & $7 \%$ & & $13 \%$ & \\
\hline & No & 25 & $71 \%$ & 5 & $14 \%$ & 3 & $9 \%$ & 2 & $6 \%$ & 35 & $100 \%$ \\
\hline Governamentais & $\%$ & $38 \%$ & & $22 \%$ & & $17 \%$ & & $14 \%$ & & $23 \%$ & \\
\hline & No & & $48 \%$ & 16 & $20 \%$ & 15 & $19 \%$ & 11 & $14 \%$ & 80 & $100 \%$ \\
\hline Sociais & $\%$ & $58 \%$ & & $70 \%$ & & $83 \%$ & & $79 \%$ & & $63 \%$ & \\
\hline & $\mathrm{N}^{\circ}$ & 65 & $54 \%$ & 23 & $19 \%$ & 18 & $15 \%$ & 14 & $12 \%$ & 120 & $100 \%$ \\
\hline Total & $\%$ & $100 \%$ & & $100 \%$ & & $100 \%$ & & $100 \%$ & & $100 \%$ & \\
\hline
\end{tabular}

* Foram registradas em ata as presenças de 148 conselheiros titulares ou suplentes, mas 28 (19\%) destes não tiveram identificadas as entidades que representavam. A Tabela 1 apresenta apenas os conselheiros cujas entidades de procedência foram encontradas.

Fonte: Rio Grande do Sul, 2006a.

O primeiro se refere à iniciativa dos gestores estaduais de saúde de criar um fundo, em 1999, destinado a auxiliar emergencialmente os hospitais privados e os filantrópicos, por meio da abertura de uma linha de crédito, com juros subsidiados, no Banco do Estado do Rio Grande do Sul (Banrisul). Os empréstimos seriam destinados à recuperação física dos hospitais e ao pagamento de dividas com fornecedores. Inicialmente, foram depositados R\$ 9 milhões no fundo, provenientes do Tesouro do Estado. ${ }^{9} \mathrm{O}$ outro projeto propunha a criação de mecanismos participativos nos hospitais contratados pelo SUS: os conselhos gestores (Rio Grande do Sul, 2001). ${ }^{10}$ Um dos pólos no conflito que cercou o debate das duas propostas no Conselho foi ocupado pelo representante dos hospitais filantrópicos. Ele

\footnotetext{
${ }^{9}$ A lei estadual n. 11.366/99 (Rio Grande do Sul, 1999a) instituiu o Fundo de Apoio Financeiro e de Recuperação dos Hospitais Privados sem Fins Lucrativos e Hospitais Públicos no Estado do Rio Grande do Sul (Funafir) e estabeleceu as seguintes fontes de recursos para esse fundo: 1) dotação orçamentária própria do Tesouro; 2) receitas decorrentes dos rendimentos de aplicações de seus recursos; 3) receitas oriundas de convênios, contratos e acordos celebrados entre o estado e instituições públicas e privadas; d) outras receitas a ele destinadas. Não poderiam ser repassados ao Funafir os recursos relativos ao SUS transferidos da União ao estado.

${ }^{10} \mathrm{O}$ Conselho aprovou resolução (Rio Grande do Sul, 2001, art. $4^{\circ}$ ) que obrigava as instituições hospitalares incluidas na Politica Estadual de Apoio e Qualificação da Assistência Hospitalar aos Usuários do SUS - Saúde Solidária - a "instituir Conselho Gestor, conforme deliberado pelo CES/RS, no prazo máximo de 60 (sessenta) dias da assinatura do contrato e propiciar condições para o seu funcionamento".
} 
atuou como aliado dos gestores de saúde estaduais, em confronto com os representantes de entidades sociais, no caso do Funafir, e entrou em conflito com os gestores e com representantes de entidades sociais, na discussão dos conselhos gestores em hospitais.

Os dois conselheiros governamentais que mais freqüentaram as reuniões provinham da Associação dos Secretários e Dirigentes Municipais da Saúde (Assedisa), presente em 56 reuniões, e da Universidade Federal do Rio Grande do Sul, que compareceu a 43 reuniões. No entanto, os gestores estaduais representados por diferentes dirigentes, que eram também conselheiros, estiveram presentes em 45 das 63 reuniões plenárias realizadas no período. Assim, mesmo que a secretária estadual de Saúde tenha comparecido a apenas 19 reuniões pessoalmente, a gestão estadual esteve representada em mais de $70 \%$ (45 em 63) das reuniões no período.

Os 11 representantes de entidades sociais que estiveram presentes a 42 ou mais reuniões pertenciam às categorias de profissionais e trabalhadores de saúde (três); trabalhadores, não especificamente de saúde (três); entidades étnicas, de gênero e de portadores de patologias ou deficiências (três); associações comunitárias, movimentos sociais e ONGs (um); e igrejas (um). A constatação de que 11 dos 14 conselheiros que freqüentaram pelo menos 42 das 63 reuniões analisadas eram representantes de entidades sociais somase aos outros indicadores que mostraram sua importância no Conselho. Ou seja, os representantes de entidades sociais que presidiram por mais tempo o Conselho, que coordenaram a maior parte das reuniões, que integravam e coordenavam a Comissão de Fiscalização eram também os mais assíduos às reuniões plenárias.

Tanto no CNS (Brasil, 2005a) como no CES/RS, esses conselheiros eram os que mais compareciam às reuniões. No entanto, no CES/RS, a possibilidade de esse tipo de representante influir no funcionamento do fórum era maior. A diferença fundamental está no fato de esses conselheiros terem constantemente exercido a presidência da Mesa Diretora do CES/RS, enquanto no fórum nacional isso somente veio a ocorrer em 2007, ao cabo de longo processo de negociação. Aliás, nesse aspecto, ainda hoje, o Conselho gaúcho distingue-se da maioria dos conselhos estaduais cujos presidentes são gestores de saúde (21 em 27 - 78\%) (Brasil, 2007).

No entanto, a existência da possibilidade de influir - indicada pela proporção de assentos no Plenário, assiduidade às reuniões plenárias e coordenação de instâncias internas - não implica necessariamente exercício 
de influência efetiva sobre o funcionamento do fórum. Já a freqüência de intervenções durante as reuniões pode indicar mais acuradamente até que ponto diferentes tipos de conselheiros afetavam o processo decisório do fórum, por meio de sua participação constante nos debates. A análise de uma amostra de 38 reuniões plenárias dentre as 84 realizadas entre 1999 e 2002 (ver nota 3) permitiu verificar, em primeiro lugar, que apenas $49 \%$ dos conselheiros presentes (73 em 150) participaram dos debates.

A Tabela 2 mostra o número de intervenções dos 150 conselheiros que compareceram às 38 reuniões analisadas. Excluídos os 77 que nunca intervieram nos debates, restaram 73 que realizaram, ao todo, 1.681 manifestações verbais ${ }^{11}$ distribuídas entre aqueles que falaram apenas uma vez e 263 vezes. Os representantes de organizações sociais foram responsáveis por $68 \%$ do total de intervenções de conselheiros (1.148 em 1.681), e cinco deles estavam entre aqueles que intervieram mais do que cinqüenta vezes. Observe-se ainda que entre os últimos estavam os únicos três participantes que intervieram mais do que cem vezes nos debates, sendo que um deles, sozinho, foi responsável por 16\% de todas as falas (263 em 1.681). As manifestações de representantes de órgãos governamentais perfizeram $26 \%$ do total das intervenções (437 em 1.681). Dentre os conselheiros provenientes de entidades de mercado, apenas um participou dos debates com freqüência: foram setenta intervenções ao longo das 38 reuniões examinadas. É o mesmo conselheiro representante da Federação das Santas Casas e Hospitais Filantrópicos do Rio Grande do Sul, que comparecia com freqüência às reuniões. Ele, portanto, também participava dos debates da plenária, em contraste com os demais representantes de entidades de mercado, que não compareciam muito às reuniões e pouco participavam nas discussões.

Após constatar que os representantes de entidades sociais eram não só os mais assíduos, mas os que mais se envolviam nos debates, buscou-se verificar as categorias de conselheiros oriundos de entidades sociais que eram mais atuantes. Dos três participantes com mais de cem intervenções nas reuniões, dois eram representantes de entidades de profissionais e trabalhadores de saúde, com 263 e 122 falas, e um representante de trabalhadores, não especificamente da área da saúde, com 103 manifestações. Os dois representantes de entidades de profissionais e trabalhadores de saúde, juntos,

\footnotetext{
${ }^{11}$ Ao todo, foram registradas 1.928 intervenções nas atas, mas 247 delas eram manifestações de não conselheiros (especialistas, convidados, integrantes da Secretaria Executiva).
} 
realizaram 23\% de todas as intervenções de conselheiros nas reuniões (385 em 1.681). Observe-se que ambos foram também presidentes da Mesa Diretora, sendo que o segundo foi, inicialmente, vice-presidente, ainda na gestão do primeiro. Essa condição lhes conferia papel preponderante nas reuniões plenárias.

Tabela 2 - Número de intervenções por tipos de conselheiros: sociais, governamentais e de mercado. CES/RS - 1999, 2000, 2001 e 2002

\begin{tabular}{|c|c|c|c|c|c|}
\hline $\begin{array}{l}\text { Número de } \\
\text { intervenções }\end{array}$ & $\begin{array}{c}\text { Não } \\
\text { identificado }\end{array}$ & $\begin{array}{c}\text { De } \\
\text { mercado }\end{array}$ & Governamentais & Sociais & Total \\
\hline 0 & 27 & 4 & 16 & 30 & 77 \\
\hline 1 a 10 & 1 & 1 & 8 & 29 & 39 \\
\hline 11 a 20 & 0 & 0 & 2 & 9 & 11 \\
\hline 21 a 30 & 1 & 0 & 3 & 4 & 8 \\
\hline 31 a 40 & 0 & 0 & 0 & 2 & 2 \\
\hline 41 a 50 & 0 & 0 & 0 & 3 & 3 \\
\hline Subtotal & 29 & 5 & 29 & 77 & 140 \\
\hline 51 a 60 & 0 & 0 & 0 & 2 & 2 \\
\hline 61 a 70 & 0 & 1 & 1 & 0 & 2 \\
\hline 71 a 80 & 0 & 0 & 2 & 0 & 2 \\
\hline 81 a 90 & 0 & 0 & 1 & 0 & 1 \\
\hline 91 a 100 & 0 & 0 & 0 & 0 & 0 \\
\hline 101 a 110 & 0 & 0 & 0 & 1 & 1 \\
\hline 111 a 120 & 0 & 0 & 0 & 0 & 0 \\
\hline 121 a 130 & 0 & 0 & 0 & 1 & 1 \\
\hline 131 a 160 & 0 & 0 & 0 & 0 & 0 \\
\hline 261 a 270 & 0 & 0 & 0 & 1 & 1 \\
\hline Subtotal 51 a 180 & 0 & 1 & 4 & 5 & 10 \\
\hline TOTAL & 29 & 6 & 33 & 82 & 150 \\
\hline
\end{tabular}

Fonte: Rio Grande do Sul, 1999b, 2006b.

Assim, ao comparar o caso do CES/RS com o do CNS, verificou-se que, embora prevaleçam as similaridades, existem algumas diferenças. Em primeiro lugar, no Conselho Estadual a predominância dos representantes de profissionais e trabalhadores de saúde foi mais explícita do que a verificada no CNS. O fórum estadual foi presidido por representantes de entidades sociais desde a sua criação, em 1994, em contraste com o que aconteceu no fórum nacional, cuja presidência permaneceu como prerrogativa do ministro da Saúde até 2006. A maioria dos presidentes do CES/RS representava entidades de profissionais e trabalhadores de saúde. Além disso, como as reuniões plenárias do Conselho Estadual eram dirigidas pelo presidente da 
Mesa Diretora - diferentemente do que acontecia no CNS, no qual existiam diferentes coordenações para cada ponto de pauta -, ampliava-se a influência dos dirigentes do CES/RS sobre o andamento das reuniões. Considerando a coordenação de instâncias internas, o número legal de conselheiros no Plenário, a freqüência às reuniões e o número de intervenções, constatou-se que os conselheiros oriundos de entidades sociais e, particularmente, aqueles que representavam profissionais e trabalhadores de saúde tinham grande influência sobre a dinâmica das reuniões.

No CES/RS, como no CNS, os conselheiros governamentais não eram tão atuantes quanto os conselheiros sociais, enquanto o conjunto dos representantes de organizações de mercado pouco participava. Como ocorria no CNS, os conselheiros governamentais, mesmo sendo menos assíduos às reuniões e, no caso do CES/RS, não coordenando o fórum, certamente exerciam influência superior àquela indicada pela presença nas reuniões e cujo número de intervenções poderia indicar. Entretanto, o fato de integrarem a Mesa Diretora lhes conferia possibilidades de intervenção sobre os rumos dos trabalhos do fórum não identificadas no CNS. Outro aspecto diferenciado no fórum estadual era a ação do conselheiro representante de hospitais filantrópicos, comparecendo freqüentemente às reuniões e intervindo constantemente nos debates.

Identificados os tipos e categorias de conselheiros que mais influenciavam as atividades do fórum, a seção seguinte procura caracterizar a dinâmica de discussões no CES/RS. Com esse objetivo, são examinados os temas mais debatidos e o processo que levava à sua inclusão nas pautas de reuniões, tratados aqui como indicadores do modo como se estruturavam as relações entre os atores societais e estatais no fórum e na arena decisória da área da saúde estadual.

\section{DinÂMICA DAs DISCUSSÕ ES NAS REUNIÕES DO ConselHo Estadual de SaÚde/RS}

O controle sobre o processo de formação da agenda de discussões se constitui em um dos principais indicadores referentes à distribuição do poder entre os participantes de um fórum. Diferentemente do Conselho Nacional, no qual a coordenação geral dos trabalhos do Plenário ficava a cargo da Secretaria Executiva, no CES/RS era a Mesa Diretora que os coordenava. Enquanto no fórum nacional a Comissão de Coordenação Geral 
(CCG) era a instância responsável pela elaboração da pauta, no estadual a Mesa Diretora acumulava também essa função.

Porém, existiam diferenças na composição das instâncias encarregadas da definição da agenda de debates em cada um dos fóruns. No Conselho Nacional, a relação de temas a serem discutidos no Plenário era elaborada pela CCG, composta, em 2005, exclusivamente por representantes de organizações sociais. No caso, a influência dos gestores não deixava de ser decisiva, tendo em vista a centralidade dos dirigentes federais na formulação e execução da política de saúde, mas era externa ao processo de definição de pautas interno à CCG. No Conselho Estadual, o gestor, além da sua posição central na formulação da política, ocupava assento na Mesa Diretora. Isso permitia que sua influência se exercesse também diretamente sobre a Mesa Diretora. De acordo com uma conselheira,

A pauta é feita pela Mesa Diretora. Na Mesa Diretora está participando também o governo do estado. Aí, quando o governo do estado tem algum projeto, programa ou ação que ele quer implementar, ele passa para a Mesa Diretora, e a Mesa Diretora coloca em pauta. (L. B., entrevista, 1/4/2003)

Houve momentos em que os gestores estaduais impuseram determinados temas e prazos de deliberação, especialmente quando se tratava de questões referentes a planos de aplicação de recursos financeiros e ao financiamento de programas ou ações. Propostas eram apresentadas perto do prazo limite, e a urgência para sua aprovação impedia a apreciação adequada delas pelo Conselho (J. A., entrevista, 23/4/2003; O. J., entrevista, 11/4/2003; R. O., entrevista, 12/5/2003). Observe-se que acrescentar assuntos desse modo na agenda é comum em conselhos municipais de Saúde (Virtuoso, 2004; Gazeta, 2004). Um entrevistado exemplifica essa dinâmica no CES/RS referindo-se à tramitação do Plano Plurianual (PPA):

É obrigatório por lei que seja aprovado no Conselho, mas quando ele chega ao Conselho para ser aprovado é aquela coisa assim: tem que ser aprovado para amanhã. E tu não consegues ler e discutir o PPA como deveria. Dai o Conselho pede para que o governo mande o PPA um mês antes. Mas eles não querem, porque aí dá mais tempo de discussão. (M. D., entrevista, 14/4/2003)

Outra diferença em relação ao CNS refere-se ao modo como nos dois fóruns se constituíam redes de atores articulados que buscavam influir no processo de formulação da agenda. No fórum nacional havia uma forte articulação de representantes de profissionais e trabalhadores da saúde, con- 
gregados no Fórum das Entidades Nacionais dos Trabalhadores da Área de Saúde (Fentas). A análise das atas das reuniões plenárias do CNS (Brasil, 2005a) mostra que esse fórum, assim como o Ministério da Saúde, em 2005, era um dos principais proponentes de assuntos para debate em Plenário. No CES, os conselheiros provenientes de entidades sociais, e particularmente os representantes de profissionais e trabalhadores de saúde, também eram muito influentes: dirigiam as principais instâncias do fórum, eram muito assíduos às reuniōes plenárias e intervinham mais nas discussões que os demais participantes. No entanto, não havia uma entidade ou um espaço publicamente reconhecido de articulação entre eles, como existia no fórum nacional. Possivelmente, os conselheiros que representavam profissionais e trabalhadores de saúde também agiam articulados a outros conselheiros provenientes de entidades sociais no CES/RS, mas não indicavam a consolidação de um padrão similar de ação em rede liderada por essa categoria de participantes, como foi encontrado no CNS.

Para compreender como se estruturavam as relações entre os atores no Conselho, foi caracterizada a dinâmica de funcionamento dos debates no CES/RS. Para isso, foram identificados e classificados os temas em pauta e a freqüência com que cada tipo ou categoria de participante intervinha nas discussões sobre cada um deles. A classificação de temas utilizada foi a seguinte:

- gestão em saúde: funcionamento e relação das instâncias de gestão em saúde, nos níveis federal, estadual e municipal;

- trabalhista/profissionais de saúde: as relações e demandas trabalhistas no âmbito do SUS;

- funcionamento e papel do Conselho/controle social: estrutura, dinâmica e papel do fórum, além de suas relações com outras instâncias de deliberação e gestão da política de saúde;

- questões financeiras: financiamento da política de saúde, nos seus diversos aspectos, tais como recursos para área da saúde, execução orçamentária, prestação de contas, distribuição dos recursos entre programas e ações, entre outros;

- organização dos serviços de saúde: organização e funcionamento dos serviços de saúde;

- politicas específicas e programas de saúde: propostas, avaliações e discussões de políticas especificas e programas de saúde;

- questões locais/particulares: assuntos pontuais ou particularizados. 
Um indicador utilizado para verificar a proporção de tempo que cada tema ocupou no conjunto das 38 reuniões examinadas foi o número de caracteres de trechos das atas dessas reuniões que puderam ser agregados em cada um dos temas. $O$ tempo dos debates pode revelar a importância de cada assunto na agenda do fórum e indicar, portanto, o papel do Conselho no contexto da área. No Gráfico 3, compara-se a importância relativa dos tipos de temas no CES/RS e no CNS.

Gráfico 3 - Número e percentual de caracteres por temas discutidos nas reuniões plenárias. CES/RS - 1999, 2000, 2001 e 2002; CNS - 2005

Funcionamento e papel do Conselho/ controle social

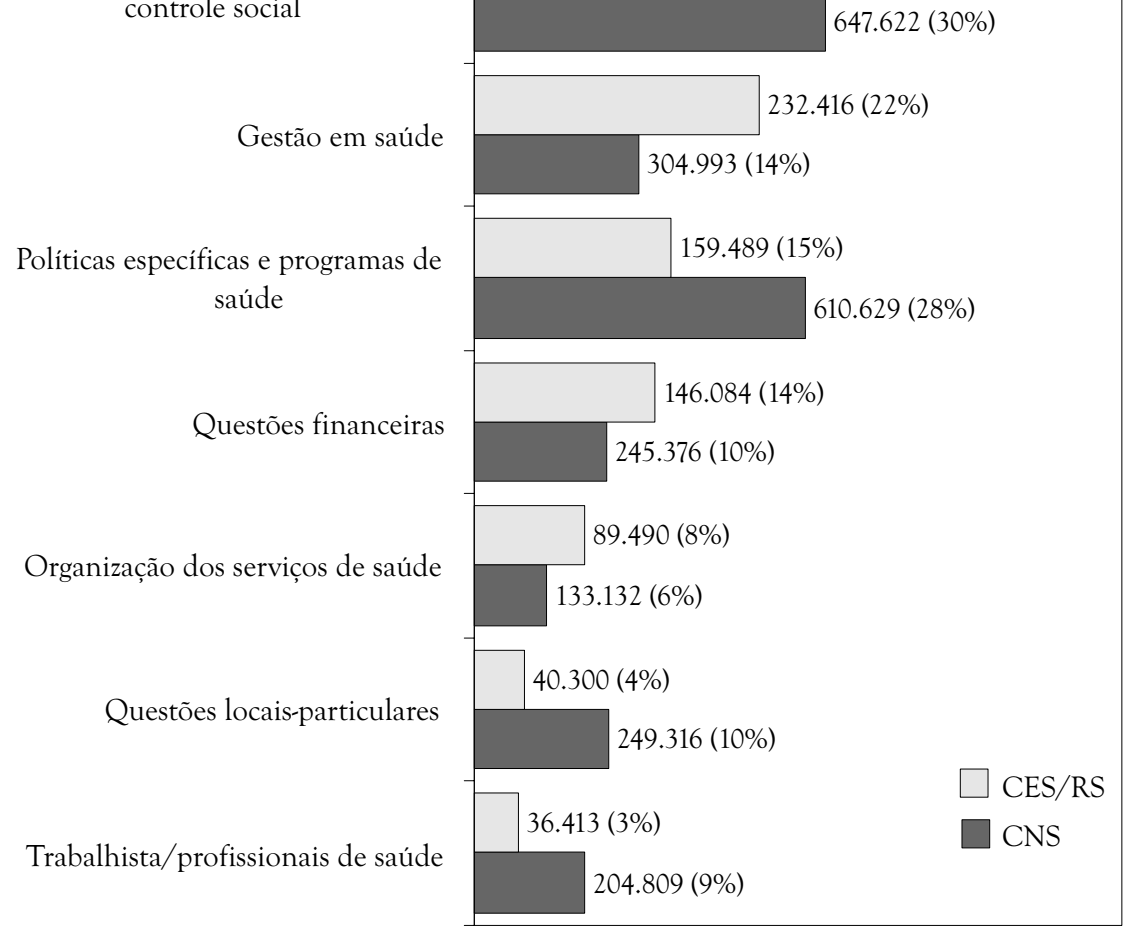

Fonte: Brasil, 2005a; Rio Grande do Sul, 1999b, 2006b.

Nos dois fóruns, predominavam as discussões sobre funcionamento e papel do Conselho e controle social. A diferença era o tipo de assunto mais discutido quando essa temática estava em pauta. No CES/RS, as intervenções tratavam principalmente do controle social em geral, abordando ques- 
tões relativas a conferências, conselhos municipais, conselhos regionais, entre outras, enquanto no fórum nacional discutia-se mais o funcionamento do próprio Conselho.

No CES/RS, em contraste com o que ocorria no CNS, o segundo tema a ser debatido mais longamente (22\%, 232.416 em 1.056.791 caracteres) era a gestão em saúde e não as políticas específicas e programas de saúde. Uma das razões para isso é que, apesar do processo de municipalização, os gestores estaduais permaneceram como provedores, contratantes e reguladores dos serviços de saúde financiados com recursos do SUS oferecidos em seus territórios. Além disso, em 2002, época em que o CES/RS foi analisado, apenas $2 \%$ dos municípios do estado estavam habilitados na modalidade de gestão plena do sistema municipal, sendo, portanto, responsáveis pela gestão de todos os serviços financiados com recursos do SUS em suas jurisdições territoriais (Brasil, 2006b; N. E., entrevista, 15/4/2003).

Assim, a gestão dos serviços de média e alta complexidades financiados com recursos do SUS, localizados fora de Porto Alegre - cidade habilitada na gestão plena do sistema municipal e que concentrava a maior parte dos serviços de referência no estado -, estava a cargo do gestor estadual. Não surpreende, portanto, que o tema estivesse entre os mais discutidos no CES/RS, uma vez que o nível estadual de administração era responsável direto pelos serviços oferecidos.

A esfera nacional de administração do SUS era responsável pela formulação de políticas específicas e programas de saúde e pela definição das diretrizes a serem seguidas por gestores estaduais e municipais. Daí a importância dessa temática nos debates travados no CNS. Ao gestor estadual, ao lado de quem atuava o CES/RS, cabia, principalmente, gerir a execução dessas políticas e programas específicos no âmbito estadual. Havia a possibilidade de formulação de políticas próprias, desde que o orçamento estadual assim o permitisse. Tendo em vista a histórica crise fiscal do governo do estado do Rio Grande do Sul, essa possibilidade, no caso, era limitada. Assim, do mesmo modo que para o CNS tratar de políticas específicas e programas de saúde era relevante, pois o fórum atuava em parceria com o gestor federal, para o CES/RS a importância do tema era secundária.

Após verificar quais os temas mais debatidos nas reuniões do CES/RS, passa-se a examinar os tipos de atores que mais se manifestaram sobre cada 
uma das temáticas em discussão. O Gráfico 4 apresenta uma comparação entre a distribuição da proporção de tempo que cada tipo de participante despendeu no debate dos temas no CES/RS e no CNS. ${ }^{12}$

Gráfico 4 - Percentual de caracteres por temas discutidos nas reuniões plenárias, segundo o tipo de representação dos participantes. CES/RS - 1999, 2000, 2001 e 2002; CNS - 2005

$\square$ Sociais $\square$ De mercado $\square$ Governamentais

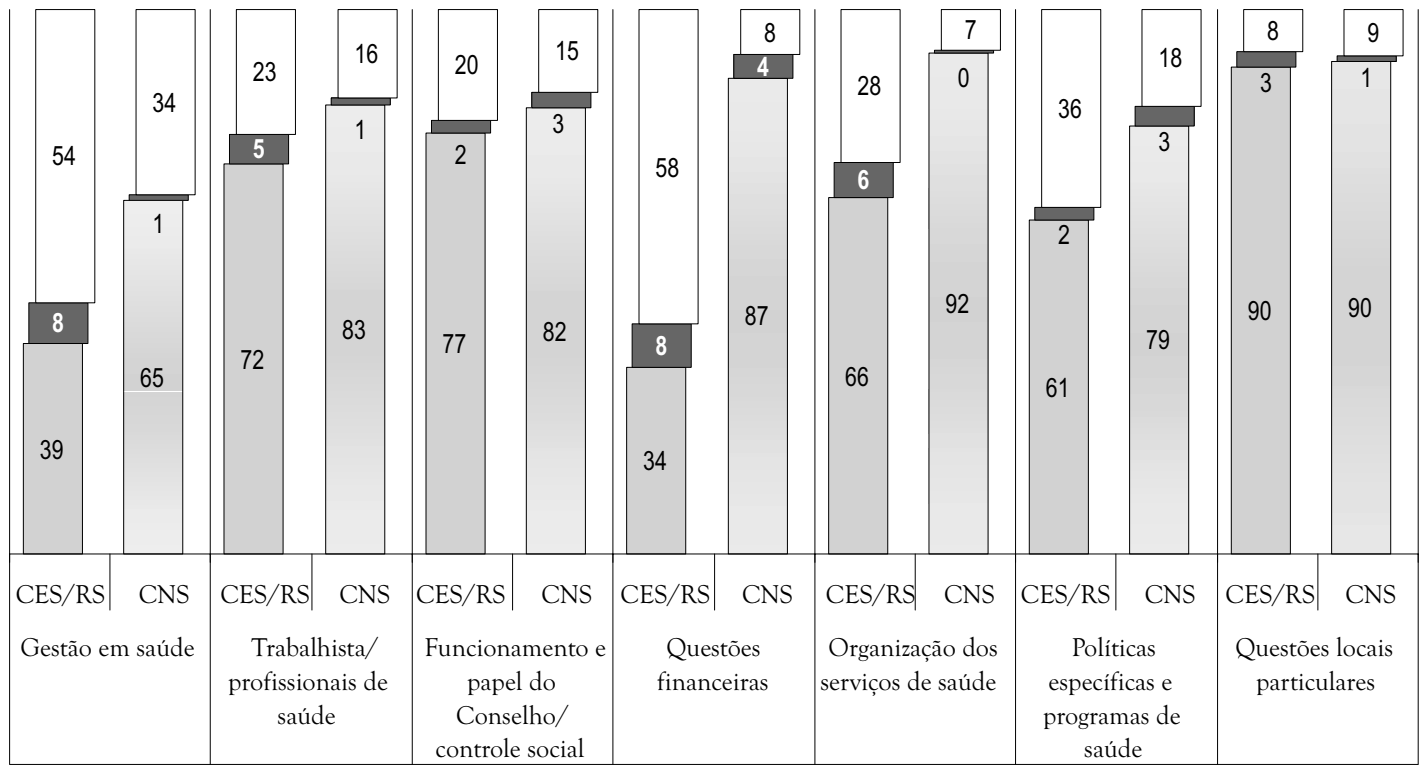

Fonte: Brasil, 2005a; Rio Grande do Sul, 1999b, 2006b.

No CES/RS, à exceção dos temas 'questões locais/particulares' e 'funcionamento e papel do Conselho/controle social', a predominância dos atores sociais como aqueles que mais longamente se manifestavam não é tão expressiva como o é no fórum nacional. Nos temas 'gestão em saúde' e 'questões financeiras', inclusive, os representantes governamentais eram os que se manifestavam mais longamente durante as reuniões $(54 \%, 87.436$ em 162.611; e 58\%, 65.264 em 113.047, respectivamente). Embora os representantes de entidades de mercado pouco se envolvessem nos debates

\footnotetext{
${ }^{12}$ Nas reuniões do CES/RS é insignificante a participação de não-conselheiros, por isso eles não estão incluídos entre os tipos de participantes cujas intervenções aqui são analisadas.
} 
nos dois fóruns, no CES/RS sua participação é levemente maior quando são tratados exatamente esses dois temas (8\%, 12.430 em 162.611; e 8\%, 9.174 em 113.047, respectivamente). Assim, no fórum estadual, mais do que no nacional, atores estatais, marcadamente os gestores de saúde estaduais, e mesmo atores de mercado, por meio de um conselheiro representante de prestadores privados de serviços de saúde, participavam ativamente dos debates nas reuniões plenárias especialmente quando o assunto versava sobre esses dois temas. Tal situação está provavelmente relacionada aos debates que cercaram a criação do Funafir e de conselhos gestores nos hospitais credenciados pelo SUS.

Nesta seção foi possível verificar, pela análise de um conjunto de indicadores, quem controlava a agenda de discussões do fórum estadual, que agenda era essa, quais temas mais mobilizavam os atores sociais, de mercado e governamentais a participar dos debates. ${ }^{13}$ No CES/RS, a coordenação geral dos trabalhos do Plenário e do fórum ficava a cargo da Mesa Diretora, formada majoritariamente pelos conselheiros provenientes de entidades sociais, mas na qual tinha assento representante do gestor estadual. Sua presença na instância formalmente responsável pela elaboração da pauta de debates contrastava com o que ocorria no CNS, no qual o papel preponderante na definição da pauta era da CCG, composta apenas por representantes de organizações sociais. No CES/RS, o gestor estadual, além de dispor de capacidade inerente de influir sobre a agenda de debates, como formulador e executor das políticas de saúde naquele nível de gestão, agia diretamente sobre a formação da pauta das reuniões plenárias por meio de seu representante na Mesa Diretora.

No fórum estadual, assim como no nacional, os representantes de profissionais e trabalhadores de saúde eram muito influentes na formação da pauta e no processo decisório do fórum. Mas no CES/RS, a articulação desse tipo de representante com outros atores sociais era menos consistente; não havia um espaço societal de articulação em torno de uma organização de profissionais e trabalhadores de saúde, como o Fentas, nos moldes do que ocorria no CNS.

Havia ainda outra diferença marcante: no CES/RS, e na área da saúde no estado, era possível identificar a presença e a predominância de atores

\footnotetext{
${ }^{13}$ Como as atas do CES/RS são mais sucintas que as do CNS, não foi possivel classificar os trechos em tipos de intervenção (informativas, questionamento ou esclarecimento etc.).
} 
identificados com o 'movimento sanitário'. Embora no interior dessa comunidade existissem divisões e divergências eventuais, não ocorriam cisões explícitas e duradouras, como foram identificadas no fórum nacional. Durante a década de 1990 (Côrtes, 1995) e no período analisado, os indivíduos que geriam a Secretaria de Saúde do estado eram membros-chave dessa comunidade de política em nível regional. O mesmo não ocorria no CNS, em 2005. Lá, as divergências entre representantes de profissionais e trabalhadores de saúde, articulados em torno do Fentas, e gestores de saúde, especialmente federais, levaram à constituição de uma nova comunidade de política.

Ao examinar os temas que compunham a pauta das reuniões plenárias do fórum constatou-se que, assim como no CNS, predominavam no CES/RS as discussões sobre 'funcionamento e papel do Conselho/controle social'. Diferentemente, no entanto, o segundo tema a tomar mais tempo de debates era 'gestão em saúde' e não 'políticas específicas e programas de saúde'. Isso porque no Rio Grande do Sul, devido à pequena proporção de municípios municipalizados na modalidade de habilitação plena do sistema municipal, o gestor estadual tinha um papel relevante na gestão de serviços, especialmente de média e alta complexidades. Já a discussão de políticas específicas e programas de saúde, tão comum no fórum nacional, era menos freqüente no Conselho Estadual, uma vez que a decisão sobre tais políticas está, em grande parte, fora do âmbito estadual de gestão.

O tema mais discutido nas reuniões plenárias do CES/RS, 'funcionamento/papel do Conselho e controle social', teve os conselheiros provenientes de entidades sociais como aqueles que mais longamente debateram assuntos a ele relacionados. Entretanto, sobre os temas 'gestão em saúde' e 'questões financeiras', a maior parte das intervenções foi de representantes governamentais - e, dentre eles, de gestores estaduais de saúde. Os conselheiros provenientes de entidades de mercado, além de pouco se manifestarem, quando o fizeram, na maioria das vezes, trataram da temática gestão em saúde, principalmente quando o assunto em pauta era a criação do Funafir ou dos conselhos gestores em hospitais credenciados pelo SUS.

A análise da tramitação dessas propostas dos gestores estaduais de saúde, no CES/RS e na arena decisória da área da saúde do estado, é essencial para que se verifique como se estruturavam, no período em exame, as relações sociais entre atores estatais e societais. Serve ainda para que daí se depreenda qual era o papel que o CES/RS desempenhava nessa arena. Tal análise é apresentada na próxima seção. 


\section{O Poder no CES/RS e o Poder do CES/RS}

No CES/RS, assim como no CNS, havia assimetria, no interior do Conselho, no que se refere à capacidade de participar das discussões e deliberações. No entanto, no fórum estadual, além de conselheiros provenientes de entidades sociais muito atuantes, havia conselheiros que representavam gestores e um representante de entidades de mercado que participavam ativamente dos debates. Dentre os representantes de entidades sociais, destacavam-se representantes de entidades de profissionais e trabalhadores de saúde, os quais, no periodo, integravam a Mesa Diretora nos cargos de presidente e vice-presidente. Como participantes dessa instância do fórum e coordenadores das reuniões plenárias, atuavam na formulação da agenda de discussões e na formulação de propostas e intervinham em praticamente todos os debates.

No fórum estadual, de modo similar ao que ocorria no nacional, os conselheiros vinculados aos interesses do mercado apresentavam uma posição subordinada, o que se expressava no número relativamente pequeno de representantes de mercado presentes às reuniões e também na sua ausência em instâncias decisórias do CES/RS. No entanto, em contraste com o que foi observado em relação ao Conselho Nacional, no fórum estadual um conselheiro, que representava a Federação das Santas Casas e Hospitais Filantrópicos do Rio Grande do Sul, participou ativamente das discussões, especialmente quando se tratava de assuntos relacionados à gestão em saúde, que poderiam afetar os interesses dos hospitais credenciados pelo SUS.

Os representantes governamentais apresentavam uma posição central no CES/RS, o que ocorria de forma mais explícita do que no CNS. No âmbito federal, os gestores influíam na definição da agenda devido à sua posição central em termos da formulação de políticas, assim como à sua capacidade de construir mecanismos de indução para sua implementação por gestores estaduais e municipais. No entanto, eles não participavam diretamente da instância do fórum - a CCG - que elaborava as pautas das reuniōes plenárias. No CES/RS, os representantes dos gestores estaduais, além de exercerem o protagonismo inerente à condição de dirigentes estaduais da área da saúde, participavam da Mesa Diretora e eram os que mais se manifestavam durante as reuniōes plenárias, quando os assuntos relacionados a gestão em saúde e questões financeiras estavam em discussão.

Outro aspecto potencializava a influência dos gestores estaduais no Conselho. No período analisado, a Secretaria Estadual de Saúde do Rio 
Grande do Sul (SES/RS) era comandada por uma ex-conselheira, vista como parceira confiável pela maioria dos representantes de organizações sociais que atuavam no fórum. Essa relação de confiança fora construída ao longo de duas décadas de trajetória da secretária. Ela pertencia ao Partido dos Trabalhadores (PT); na década de 1980, representara a Central Única dos Trabalhadores (CUT) em diversas instâncias nacionais da área da saúde; fora secretária municipal de Saúde de Porto Alegre, além de ter sido conselheira do CES/RS, no final da década de 1990. Assim, entre a SES e o Conselho havia uma relação de confiança que levava os conselheiros provenientes de entidades sociais a se alinharem, na maioria das vezes, com as posições do governo. Segundo um entrevistado,

isso foi bastante presente no governo anterior, quando havia quase que uma unanimidade dos usuários em relação ao segmento gestor estadual (...), de apoiar as decisões e politicas que o governo trazia, sem maiores questionamentos. (K. A., entrevista, 7/5/2003)

Se a estreiteza dos laços de confiança entre atores sociais e governamentais, por um lado, favorecia os primeiros, uma vez que havia a boa vontade do gestor em atender às suas demandas; por outro, aumentava o poder de influência dos últimos sobre o processo decisório do Conselho (P. L., entrevista, 1\%/4/2003). Isso não significa que não existissem conflitos entre conselheiros representantes de entidades sociais e governamentais. A tramitação, no Conselho, dos dois assuntos que mobilizaram a atenção do representante da Federação das Santas Casas e Hospitais Filantrópicos do Rio Grande do Sul mostra que, inicialmente, as posições de atores sociais e governamentais eram conflitantes, mas que no final houve uma ação conjunta e articulada.

O motivo de discórdia foi a criação e implantação do Funafir. Participaram da elaboração da proposta desse fundo ${ }^{14}$ a Federação das Santas Casas e Hospitais Filantrópicos do Rio Grande do Sul, a Associação dos Secretários e Dirigentes Municipais de Saúde (Assedisa), o Banco do Estado do Rio Grande do Sul (Banrisul) e a Secretaria Estadual de Saúde (Pereira, 2006). Segundo Pereira, o Funafir começou a ser discutido nas reuniões plenárias do CES/RS quando o projeto de sua criação já tramitava na

\footnotetext{
${ }^{14}$ Inicialmente, o Funafir seria também destinado aos hospitais públicos. Posteriormente, ficou restrito aos hospitais privados sem fins lucrativos.
} 
Assembléia Legislativa. $\mathrm{O}$ envio do projeto à Assembléia antes de discuti-lo no CES/RS provocou manifestações de desagrado de conselheiros que representavam organizações sociais.

Os conflitos se acirraram durante as discussões do projeto (Pereira, 2006). De um lado, francamente a favor do projeto, estavam os representantes de gestores de saúde e de prestadores de serviços de saúde; de outro, contrários à aprovação do projeto, posicionavam-se os conselheiros provenientes de organizações sociais, liderados por representantes de entidades de profissionais e trabalhadores de saúde. Para um destes, o gestor estadual

teve uma posição horrorosa. Ele trouxe o projeto para o Conselho achando que o Conselho tinha que aprovar sem a gente discutir. Na mesma plenária que ele trouxe, ele queria que nós aprovássemos. Saiu dali para ir à Assembléia Legislativa pressionar os deputados a favor da proposta deles. Nós ficamos espantados, porque a gente nunca esperava esse tipo de proposição do gestor que estava entrando. (P. L., entrevista, 1/4/2003)

A última frase demonstra que conselheiros oriundos de organizações sociais tinham a expectativa de que os gestores estaduais, ao assumirem a direção da SES, em 1999, fortalecessem o fórum e, portanto, os atores sociais que nele tinham predominância. A apresentação de um projeto que favorecia os interesses de mercado, e que fora enviado à Assembléia Legislativa sem ser previamente discutido no Conselho, era vista pelos conselheiros oriundos de entidades sociais como uma atitude decepcionante. A oferta de financiamento a baixo custo para hospitais privados e a aliança circunstancial com atores de mercado foram encaradas por esses conselheiros como surpresas negativas.

O representante dos hospitais filantrópicos, identificando as restrições dos conselheiros provenientes de entidades sociais, mas percebendo também a existência de laços políticos entre estes e o PT, procurou acioná-los para facilitar a aprovação do projeto do Funafir na Assembléia Legislativa. Segundo ele, esses conselheiros

não queriam dar dinheiro. Não queriam porque [diziam que] os hospitais não tinham compromisso com o SUS. (...) Nós fomos falar com todos os deputados na Assembléia Legislativa; 55 deputados, inclusive os deputados do PT. Nós fomos lá e explicamos para eles exatamente o que nós queriamos, e eles assopraram para os [conselheiros representantes de usuários e de trabalhadores de saúde] que se não concordassem com a aprovação do Funafir, que pelo menos 
não atrapalhassem. Foi difícil, tanto que as discussões passavam ali por um votinho. Eu me articulei, conversava com todas as pessoas. (O. J., entrevista, $11 / 4 / 2003)$

Como uma espécie de resposta às reclamações dos representantes de organizações sociais, ainda em 1999 os gestores estaduais de saúde propuseram a criação de uma Política Estadual de Apoio e Qualificação da Assistência Hospitalar aos Usuários do SUS. Segundo Pereira (2006), a política estadual tinha por finalidade propiciar a recuperação financeira, a atualização tecnológica, a formação da rede regional de referência e contra-referência e a reorganização da assistência hospitalar aos usuários do SUS, mas exigia dos hospitais por ela beneficiados um conjunto de contrapartidas (J. A., entrevista, 23/4/2003). Dentre elas, destacava-se a exigência de criação de conselhos gestores. Essa exigência foi acrescentada ao projeto durante sua tramitação no Conselho por iniciativa dos conselheiros provenientes de organizações sociais, vindo a ser apoiada pelos gestores estaduais de saúde. Os representantes tanto da Federação das Santas Casas e Hospitais Filantrópicos do Rio Grande do Sul como dos gestores municipais, aliados aos donos de hospitais privados nos municípios, foram contrários ao acréscimo da exigência ao projeto. Nesse caso, a cisão entre os conselheiros foi diferente da que ocorreu na tramitação do Funafir. De um lado, a favor da proposta, posicionaram-se os conselheiros oriundos de entidades sociais e os gestores estaduais; de outro, os representantes de entidades de mercado.

A vitória, no Plenário do $\mathrm{CES} / \mathrm{RS}$, da proposta que criava os conselhos gestores levou a Federação das Santas Casas e Hospitais Filantrópicos do Rio Grande do Sul a recorrer ao Ministério Público, o qual obteve, no Poder Judiciário, a revogação da resolução do CES/RS. Resolvia-se desse modo, conforme o representante da federação no Conselho, um problema de "interferência indevida na administração hospitalar" (O. J., entrevista, 11/4/2003). A partir da revogação da resolução do CES/RS, estabeleceu-se uma negociação que substituiu os conselhos gestores por câmaras técnicas, a serem criadas nos conselhos municipais, com a finalidade de fiscalizarem os gastos realizados no âmbito da Política Estadual de Apoio e Qualificação da Assistência Hospitalar aos Usuários do SUS (Pereira, 2006).

Duas constatações podem ser feitas em relação aos debates que cercaram a aprovação do Funafir e a proposta de criação dos conselhos gestores nos hospitais credenciados pelo SUS. A primeira é que, no CES/RS, havia conflitos entre o grupo de conselheiros oriundos de entidades sociais e 
governamentais, mas eles não eram profundos. As divergências entre os dois grupos de conselheiros eram eventuais. As trajetórias políticas de dirigentes da SES e lideranças de entidades sociais que atuavam no Conselho apresentavam similaridades e momentos prévios de interconexão que favoreciam o estabelecimento de laços de confiança mútua. Confrontos pontuais não implicavam dissolução desses laços, uma vez que eles compartilhavam idéias sobre princípios e resultados das políticas a serem implementadas. Os gestores tinham preponderância no interior do CES/RS porque detinham as informações e produziam ações de gestão que impunham ao fórum a agenda de debates. Mas para que o resultado das discussões lhes favorecesse, era essencial a aliança com os atores sociais que atuavam no Conselho, os quais controlavam as instâncias decisórias e assessoras do fórum.

A segunda constatação refere-se à situação do Conselho na configuração das relações no âmbito da área da saúde no Rio Grande do Sul. A posição dos atores internamente ao CES/RS não refletia sua posição na arena decisória setorial no estado. Os processos que levaram à aprovação da criação do Funafir e das câmaras técnicas nos conselhos municipais mostraram que gestores estaduais e prestadores privados de serviços ocupavam posições dominantes na rede de política da área, ao contrário do que acontecia no interior do Conselho. Na arena decisória setorial, a possibilidade de o Conselho influir nas decisões sobre políticas de saúde formuladas e executadas em âmbito estadual não dependia unicamente da forma como se estruturaram as relações do fórum e dos atores sociais com os gestores. No âmbito estadual, especialmente no caso de um governo cuja coalizão governante era minoritária no Legislativo, as decisões do Conselho dependiam, muitas vezes, de aprovação dos Poderes Legislativo ou Judiciário. Mesmo que os atores sociais predominassem no processo decisório do CES/RS, as resoluções do fórum dependiam do referendo de outras instâncias politicas legítimas - do Legislativo ou do Judiciário - para se transformarem em ações ou em políticas passiveis de implementação.

O CES/RS participava do processo de construção da sua posição no contexto da política de saúde estadual por meio das relações que estabelecia com os atores, fóruns participativos e órgãos públicos da área. No interior do Conselho houve o estreitamento das relações entre as lideranças de entidades de profissionais de saúde, não médicos; os integrantes dos conselhos regionais de Saúde, cujos representantes no Conselho Estadual eram oriundos de organizações sociais; os representantes de organizações sociais 
que atuavam em conselhos municipais de Saúde; e, muitas vezes, os dirigentes da SES. Essa articulação de atores fortaleceu a posição do Conselho no contexto da política de saúde estadual e ofereceu o suporte político para que esses mesmos atores pudessem confrontar as propostas defendidas pelos prestadores privados de serviços de saúde, em aliança com gestores municipais de saúde. Mesmo quando os gestores de saúde estaduais defenderam propostas próximas daquelas apoiadas pela aliança identificada com os interesses de mercado, como no caso do Funafir, no Conselho as posições defendidas pelos atores sociais foram vitoriosas.

No entanto, a comunidade identificada com os interesses de mercado claramente minoritária e pouco influente no Conselho -, ao ter suas propostas derrotadas no CES/RS, recorria a outros espaços de decisão nos quais obtinha deliberações que se impunham sobre as do fórum. No caso do Funafir, o Poder Legislativo aprovou o projeto, mesmo que o CES/RS houvesse rejeitado a criação desse fundo. No caso dos conselhos gestores, mesmo que os dirigentes estaduais apoiassem a posição majoritária no Conselho, isso não foi suficiente para impedir que o Ministério Público, agindo em nome dos prestadores privados de serviços de saúde, obtivesse na Justiça a revogação da resolução do CES/RS que havia criado esses conselhos.

A principal conclusão desta seção é que, assim como no CNS, a posição dominante dos conselheiros provenientes de entidades sociais no CES não correspondia à preponderância no processo decisório da arena decisória setorial. A dominância no interior do Conselho era o resultado da ação em rede de representantes de organizações sociais, que atuavam nos conselhos estadual, regionais e municipais de saúde, articulados aos dirigentes estaduais de saúde. No entanto, fora do Conselho, as articulações dos conselheiros de mercado com atores-chave nos Poderes Judiciário e Legislativo e com gestores municipais transformavam-se em poder de veto a propostas vencedoras no CES/RS.

\section{Consideraçõ es Finais}

A análise da dinâmica das relações sociais no interior do CES/RS e da posição do fórum na configuração das relações sociais da área da saúde no estado do Rio Grande do Sul permitiu que se chegasse a três principais constatações. A primeira é que, assim como no CNS, os representantes de organizações de profissionais e trabalhadores de saúde e de trabalhadores, 
não especificamente da área da saúde, destacavam-se, em termos de assiduidade às reuniões, coordenação de instâncias do fórum e freqüência de intervenções. A segunda é que os gestores estaduais tinham muita influência sobre o processo decisório do Conselho. Sua capacidade de influir sobre a formação da pauta e sobre a dinâmica de funcionamento do fórum era maior do que aquela verificada no CNS.

A terceira constatação é que, assim como no CNS, a hegemonia dos atores sociais, no interior do conselho estadual, não se expressava na ocupação de posição superior na arena política setorial do estado. A dominância no interior do Conselho era o resultado da ação de representantes de organizações sociais que atuavam nos conselhos estadual, regionais e municipais de saúde, articulados aos dirigentes estaduais de saúde. No entanto, fora do âmbito do Conselho, as posições de certa forma se invertiam. Os conselheiros de mercado - que exerciam pouca influência sobre o processo decisório do fórum - estabeleciam relações, ou acionavam canais preexistentes de relacionamento, com atores-chave nos Poderes Judiciário e Legislativo e com gestores municipais para impedir que decisões do CES/RS contrárias aos seus interesses fossem implementadas, assim como para garantir que aqueles projetos de seu interesse fossem implementados.

\section{REFERÊNCIAS}

AVRITZER, L. O orçamento participativo: as experiências de Belo Horizonte e Porto Alegre. In: DAGNINO, E. (Org.) Sociedade Civil e Espaços Públicos no Brasil. São Paulo: Paz e Terra, 2002.

BAIERLE, S. G. Um Novo Princípio Ético-Politico: prática social e sujeito nos movimentos populares urbanos em Porto Alegre nos anos 80, 1992. Dissertação de Mestrado, Campinas: Universidade Estadual de Campinas.

BANDEIRA, P. Participação, Articulação de Atores Sociais e Desenvolvimento Regional. Texto para Discussão 630. Brasília: Ipea, 1999.

BRASIL. Lei n. 8.142, de 28 de dezembro de 1990. Dispõe sobre a participação da comunidade na gestão do Sistema Único de Saúde (SUS).

BRASIL. Ministério da Saúde. Norma Operacional Básica do Sistema Único de Saúde (NOB-SUS) n. 01/93, de 20 de maio de 1993.

BRASIL. Decreto n. 1.353, de 29 de dezembro de 1994. Altera o artigo 2o do decreto n. 99.438 , de 7 de agosto de 1990, que dispõe sobre a composição do Conselho Nacional de Saúde.

BRASIL. Ministério da Saúde. Norma Operacional Básica do Sistema Único de Saúde (NOB-SUS) n. 01/96, de 6 de novembro de 1996. 
BRASIL. Ministério da Saúde. Norma Operacional da Assistência à Saúde do Sistema Único de Saúde (Noas-SUS) n. 01/02, de 27 de fevereiro de 2002.

BRASIL. Conselho Nacional de Saúde. Atas de reunião. Disponivel em: <http:// conselho.saude.gov.br/atas/atas_08.htm>. Acesso em: jun.-dez. de 2005a.

BRASIL. Ministério da Saúde. Secretaria Executiva. Subsecretaria de Planejamento e Orçamento. Plano Nacional de Saúde: um pacto pela saúde no Brasil - síntese. Brasília: Ministério da Saúde, 2005b.

BRASIL. Ministério da Saúde. Secretaria Executiva. Departamento de Apoio à Descentralização. Pacto de Gestão: garantindo saúde para todos. Brasília: Ministério da Saúde, 2005c.

BRASIL. Decreto n. 5.839, de 11 de julho de 2006a. Dispõe sobre a organização, as atribuições e o processo eleitoral do Conselho Nacional de Saúde e dá outras providências.

BRASIL. Ministério da Saúde. Departamento de Apoio à Descentralização. Disponivel em: 〈http://dtr2001.saude.gov.br/dad/habilitacoes/MunicPlenas.pdf〉. Acesso em: 15 ago. $2006 \mathrm{~b}$.

BRASIL. Ministério da Saúde. Secretaria de Gestão Participativa. Disponível em: <http:/ /portal.saude.gov.br/portal/saude/cidadao/area.cfm?id_area=1103>. Acesso em: 20 out. 2007.

COHEN, J. L. Sociedade civil e globalização: repensando categorias. Dados - Revista de Ciências Sociais, 46(3): 419-459, 2003.

CÔRTES, S. M. V. User Participation and Reform of the Brazilian Health System: the case of Porto Alegre, 1995. Tese de Doutorado, Londres: Department of Social Policy and Administration, London School of Economics and Political Science.

GAZETA, A. P. Democracia e participação social: a experiência dos conselhos municipais de Saúde no interior de São Paulo. Em Tese, 1(2): 1-19, 2004.

INSTITUTO BRASILEIRO DE GEOGRAFIA E ESTATÍSTICA (IBGE), 1996. Disponivel em: <www.ibge.gov.br/home/estatistica/populacao/condicaodevida/ indicadoresminimos/suppme/analiseresultados1.shtm>. Acesso em: 22 nov. 2007.

PACHECO, E. Oficina de Contratualização dos Hospitais Filantrópicos do SUS. Porto Alegre: Secretaria de Saúde do Estado do Rio Grande do Sul, 2007. Disponível em: <www.saude.rs.gov.br/dados/1175536225948contratualizacao_filantropicos.ppt>. Acesso em: $16 \mathrm{dez} .2007$.

PEREIRA, E. O. Conselho Estadual de Saúde do Rio Grande do Sul: atores, conflitos e articulações - 1999 a 2002, 2006. Dissertação de Mestrado, Porto Alegre: Programa de Pós-Graduação em Sociologia, Instituto de Filosofia e Ciências Humanas, Universidade Federal do Rio Grande do Sul.

RIO GRANDE DO SUL. Lei estadual n. 10.097, de 31 de janeiro de 1994. Cria o Conselho Estadual de Saúde do Estado do Rio Grande do Sul e estabelece outras providências. 
RIO GRANDE DO SUL. Lei Estadual n. 11.366, de 31 de agosto de 1999a. Institui o Fundo de Apoio Financeiro e de Recuperação dos Hospitais Privados, sem Fins Lucrativos e Hospitais Públicos (Funafir) e dá outras providências.

RIO GRANDE DO SUL. Conselho Estadual de Saúde. Secretaria Executiva. Atas de reuniões plenárias. CES/RS, 1999b. (Mimeo.)

RIO GRANDE DO SUL. Conselho Estadual de Saúde. Resolução n. 7, de 5 de julho de 2001. Aprova condições para a inclusão de unidades hospitalares na Política Estadual de Apoio e Qualificação da Assistência Hospitalar aos Usuários do SUS - Saúde Solidária.

RIO GRANDE DO SUL. Conselho Estadual de Saúde. Secretaria Executiva. CES/ RS, 2006a. (Mimeo.)

RIO GRANDE DO SUL. Conselho Estadual de Saúde. Atas de reunião. Disponível em: 〈www.saude.rs.gov.br/wsa/portal/index.jsp?menu=organograma\& cod=26641>. Acesso em: dez. 2006b.

RIO GRANDE DO SUL. Conselho Estadual de Saúde. Secretaria Executiva. Lista de presidentes do CES/RS. CES/RS, 2007a. (Mimeo.)

RIO GRANDE DO SUL. Conselho Estadual de Saúde. Secretaria Executiva. Instâncias assessoras do CES/RS. CES/RS, 2007b. (Mimeo.)

SARTORI, G. Comparación y método comparativo. In: MORLINO, L. \& SARTORI, G. (Coords.) La Comparación en las Ciencias Sociales. Madri: Alianza Editorial, 1994.

SILVA, M. K. A Construção da 'Participação Popular': análise comparativa de processos de participação social na discussão pública do orçamento em municípios da Região Metropolitana de Porto Alegre/RS, 2001. Tese de Doutorado, Porto Alegre: Programa de Pós-Graduação em Sociologia, Instituto de Filosofia e Ciências Humanas, Universidade Federal do Rio Grande do Sul.

VIRTUOSO, A. A. A Participação dos Usuários no Conselho Municipal de Saúde de Canoas/ RS, 2004. Dissertação de Mestrado, Porto Alegre: Programa de Pós-Graduação em Sociologia, Instituto de Filosofia e Ciências Humanas, Universidade Federal do Rio Grande do Sul.

\section{ENTREVISTAS}

J. A. Entrevista realizada em 23 de abril de 2003. Porto Alegre. Transcrita. Arquivos GPPS/UFRGS.

K. A. Entrevista realizada em 7 de maio de 2003. Porto Alegre. Transcrita. Arquivos GPPS/UFRGS.

L. B. Entrevista realizada em $1^{\circ}$ de abril de 2003. Porto Alegre. Transcrita. Arquivos GPPS/UFRGS.

M. D. Entrevista realizada em 14 de abril de 2003. Porto Alegre. Transcrita. Arquivos GPPS/UFRGS.

N. E. Entrevista realizada em 15 de abril de 2003. Porto Alegre. Transcrita. Arquivos GPPS/UFRGS. 
O. J. Entrevista realizada em 11 de abril de 2003. Porto Alegre. Transcrita. Arquivos GPPS/UFRGS.

P. L. Entrevista realizada em 1º de abril de 2003. Porto Alegre. Transcrita. Arquivos GPPS/UFRGS.

R. O. Entrevista realizada em 12 de maio de 2003. Porto Alegre. Transcrita. Arquivos GPPS/UFRGS. 


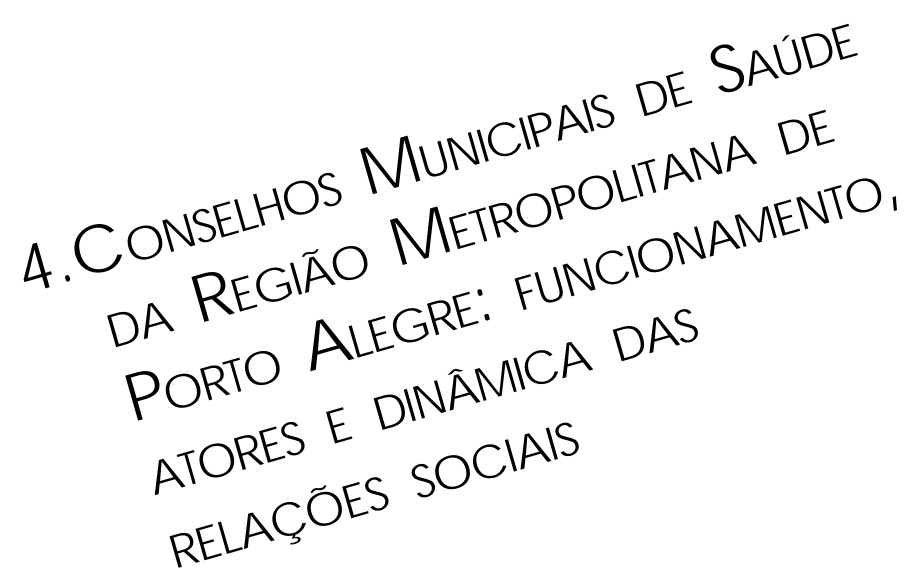

Soraya Vargas Côrtes

Fernando Canto Michelotti

Adriane Cristine Goldoni

Liege Adamski dos Santos

Este capitulo examina processos participativos em conselhos municipais de Saúde como um meio de revelar o papel por eles desempenhado na gestão pública em relação à política setorial, em nível municipal. Independentemente das prescrições legais que conferem funções específicas a essas instâncias, a ação concreta dos diferentes atores envolvidos organiza-se por meio de regras que são fruto do ambiente institucional da área da saúde e da dinâmica de relações sociais que ali se estabelece. $O$ presente estudo destaca a importância das características institucionais em condicionar processos sociais e políticos e em modelar a ação dos atores, mas também reconhece a importância da dinâmica das relações entre atores societais e estatais nos conselhos municipais de Saúde da Região Metropolitana de Porto Alegre (RMPA).

A Constituição do Estado do Rio Grande do Sul (Rio Grande do Sul, 1989, art. 16), em acordo com a Constituição Federal (Brasil, 1988, art. 25), conferiu ao estado o poder de instituir regiões metropolitanas para integrar a organização, o planejamento e a execução das funções públicas de interesse comum aos municípios que as componham. No entanto, as unidades subnacionais da federação são apenas os estados e os municípios. Não existem unidades metropolitanas de gestão, embora a execução de políticas públicas exija articulação regional, especialmente nas metrópoles que con- 
centram grande parte dos recursos e serviços existentes nos estados. A RMPA, ${ }^{1}$ instituída em 1974 (Brasil, 1974), é considerada uma das regiões metropolitanas mais antigas e consolidadas do país, ao lado das regiões de São Paulo, Rio de Janeiro, Belo Horizonte, Salvador e Belém (Pinto, 2007). A inexistência de uma dimensão administrativa metropolitana apresenta-se como um desafio à capacidade de articulação das esferas de governo constituídas - entre si e com outros órgãos envolvidos no planejamento e na gestão metropolitana.

Isso não significa que a metrópole Porto Alegre não exista concretamente. As ações nas áreas de saúde, educação, transporte, eletrificação e gestão ambiental, entre tantas, demandam a atuação coordenada de gestores públicos municipais, estaduais e dos órgãos de gestão metropolitana. Ao mesmo tempo, com a criação de fóruns participativos municipais, na segunda metade da década de 1980, atores societais adentraram a esfera pública em âmbito estadual, metropolitano e municipal.

No caso da RMPA, chama a atenção a existência de uma cultura cívica que favorece o desenvolvimento de estruturas e a deflagração de processos participativos de gestão democrática (Labra, 2002; Observatório, 2005). Os municípios da RMPA apresentam padrões altos de associativismo e interesse por política (Baierle, 1992; IBGE, 1996; Silva, 2001) e grande diversidade em termos de tamanho da população e da economia. ${ }^{3}$ A conjugação da existência de conselhos institucionalizados consolidados na área da saúde, pioneira dentre as áreas de políticas públicas na criação e dissemina-

\footnotetext{
${ }^{1}$ São os seguintes os municipios que compõem a RMPA: Alvorada, Araricá, Arroio dos Ratos, Cachoeirinha, Campo Bom, Canoas, Capela de Santana, Charqueadas, Dois Irmãos, Eldorado do Sul, Estância Velha, Esteio, Glorinha, Gravatai, Guaiba, Ivoti, Montenegro, Nova Hartz, Nova Santa Rita, Novo Hamburgo, Parobé, Portão, Porto Alegre, Santo Antônio da Patrulha, São Jerônimo, São Leopoldo, Sapiranga, Sapucaia do Sul, Taquara, Triunfo e Viamão.

2 Segundo estimativa da Fundação de Economia e Estatística (FEE, 2007), em 2006, a menor população municipal encontrava-se em Araricá, com 4.671 habitantes, e a maior em Porto Alegre, com 1.412.466 habitantes; a população total da Região Metropolitana era de 4.052.995 habitantes.

${ }^{3}$ Em 2004, a indústria e os serviços predominavam em termos econômicos. Dentre os 31 municipios, 18 apresentavam mais de 50\% do Produto Interno Bruto (PIB) municipal formado pelo setor industrial: Campo Bom, Canoas, Charqueadas, Dois Irmãos, Eldorado do Sul, Estância Velha, Glorinha, Gravatai, Guaiba, Ivoti, Montenegro, Nova Hartz, Nova Santa Rita, Parobé, Portão, Sapiranga, Sapucaia do Sul e Triunfo; cinco apresentavam mais de 50\% do PIB municipal formado pelo total dos serviços: Alvorada, Arroio dos Ratos, Porto Alegre, Taquara e Viamão. Na maior parte dos municipios da RMPA, a participação do setor agropecuário na composição do PIB municipal era pequena; apenas cinco apresentavam participação de mais de $10 \%$ do setor agropecuário na formação do PIB municipal: Arroio dos Ratos, Capela de Santana, Glorinha, São Jerônimo e Santo Antônio da Patrulha (FEE, 2007).
} 
ção de fóruns participativos municipais (Brasil, 2007a; Côrtes, 2003) e de cultura cívica e associativa relativamente consistente, permite supor que exatamente nos conselhos de Saúde, nessa região, existam condições institucionais e políticas favoráveis para que os fóruns desempenhem papel relevante na gestão pública da área.

O universo analisado foi o dos conselhos de Saúde da RMPA. Assim, os resultados são generalizáveis apenas para as cidades da RMPA, mas, provavelmente, seria possível chegar a conclusões similares para regiões metropolitanas do Sul e do Sudeste do país, uma vez que essas regiões metropolitanas apresentam similaridades em termos de características sociais e econômicas. Mesmo considerando os limites da capacidade de generalização deste estudo, há que se considerar que características comuns identificadas no funcionamento dos conselhos examinados - aquelas mais recorrentes podem ter resultado do desenho institucional do Sistema Único de Saúde (SUS), que estaria produzindo um padrão de 'conselho municipal' no país.

Ao examinar os conselhos, parte-se do pressuposto de que o arcabouço institucional - entendido como o conjunto de normas legais e administrativas e de regras institucionalizadas de funcionamento de cada área de política pública - cria e estabelece as regras básicas que regem a dinâmica política nos fóruns. O arcabouço institucional, ao condicionar o modo como a provisão de bens e serviços é financiada, produzida e distribuída, ao definir os beneficiários preferenciais dessa provisão e os profissionais com ela envolvidos, influencia na demarcação de quais atores estatais e societais podem se interessar e se mobilizar para participar nas decisões politicas de cada área, seja nos conselhos, seja fora deles.

Entretanto, as regras de funcionamento dos conselhos, que foram sendo construidas desde 1990, quando os primeiros conselhos municipais foram criados, levaram à implantação e consolidação desses fóruns como característica integrante da maneira como são geridas as políticas de saúde no país. Os atores estatais e societais que se mobilizaram para participar nesses fóruns tiveram um papel preponderante na definição dessas regras. Suas preferências, idéias e propostas, ao estabelecer conflitos e criar consensos, no interior desses fóruns e fora deles, foram aos poucos moldando, guardados os marcos legais, as características de seu funcionamento.

A disseminação de conselhos de Saúde pelo país não é garantia de que em todas as localidades atores societais envolvam-se nas atividades dos conselhos de forma autônoma e consistente. Em alguns há intensa participação 
de representantes do movimento popular e sindical; outros existem como um instrumento formal de gestão, criado para responder à exigência legal de viabilizar acesso a recursos financeiros. Assim, eles podem constituir-se como espaços governamentais onde decisões já tomadas são legitimadas ou onde se arregimentam forças para disputas que, de fato, ocorrem em outros lugares (Côrtes, 2005). Podem, ainda, transformar-se em canais de incorporação de demandas de atores societais ou em arenas em que consensos são negociados e disputas em torno de propostas conflituosas são travadas.

Este capítulo não focaliza casos isolados e as funções peculiares de cada fórum no contexto da área da saúde municipal. Ao contrário, busca identificar as características recorrentes no modo de funcionamento dos conselhos analisados. Para isso, examina o universo dos conselhos municipais de Saúde da RMPA, combinando dois tipos de análises: de dados documentais e informações obtidas por meio de questionários, em todos os 31 conselhos em funcionamento, de setembro de 2003 a janeiro de 2004; e de entrevistas semi-estruturadas, realizadas em 2005 e 2006, com uma amostra representativa de conselheiros de saúde. Os dados documentais e resultantes da aplicação dos questionários permitiram caracterizar as condições de infra-estrutura e funcionamento dos conselhos. ${ }^{4}$ Possibilitaram também a elaboração de uma lista dos 801 conselheiros que integravam os conselhos de Saúde da RMPA no final de 2004, a partir da qual foi construída a amostra representativa de entrevistados. ${ }^{5}$ Dessa forma, foi selecionado um total de 92 respondentes: 58 provenientes de entidades sociais, 25 de órgãos governamentais e nove de organizações de mercado.

A análise das entrevistas permitiu complementar as informações sobre as condições de funcionamento dos fóruns, bem como verificar qual era a percepção dos conselheiros sobre o modo como se estruturavam as relações entre atores estatais e societais no conselho e sobre o papel do fórum no processo decisório da área da saúde municipal. A percepção dos entrevista-

\footnotetext{
${ }^{4}$ Os dados foram obtidos de órgãos estaduais ou, quando necessário, de cada um dos conselhos, por meio de contato telefônico, correio ou meio eletrônico.

${ }^{5} \mathrm{O}$ tamanho da amostra foi definido utilizando-se como parâmetro um intervalo de confiança de $90 \%$, se considerado um erro relativo máximo de $8 \%$. O processo de amostragem adotado foi probabilistico, mais precisamente o método de amostragem aleatória simples, que consiste na seleção das unidades amostrais, em que cada uma tem igual probabilidade de seleção. Para a composição da amostra, não houve qualquer tipo de estratificação por cidade e/ou por tipo de representante.
} 
dos é uma fonte limitada de informações, pois cada tipo de ator expressa uma visão parcial sobre o fenômeno social em foco, falando conforme a sua posição na sociedade e, no caso, no conselho e na arena decisória da área da saúde no município. No entanto, como foram considerados os depoimentos de respondentes que pertencem a diferentes categorias de conselheiros, tal triangulação possibilitou que as impressões mais recorrentes fossem consideradas como indicação de funções freqüentemente exercidas pelos conselhos.

As informações dos entrevistados sobre as condições de infra-estrutura e suas percepções sobre o papel dos conselhos no contexto local da política de saúde foram categorizadas tendo em vista a freqüencia com que eles as mencionavam. Assim, registrou-se o percentual dos 92 respondentes que ofereceram determinadas informações ou interpretações. Dois esclarecimentos adicionais devem ser feitos. Em primeiro lugar, cada entrevistado podia mencionar, por exemplo, mais de um coordenador de reuniões, um tema de pauta ou papel do conselho. Nesses casos todas as menções são consideradas, mas o percentual foi construído sempre em relação ao total de entrevistados. Em segundo lugar, o respondente por vezes atribuía ao conselho papéis contraditórios, tais como 'deliberativo' e 'instrumento formal de gestão'. Nesse caso, optou-se por excluir as respostas de cunho 'normativo' (o que a lei estabelece ou o papel que o entrevistado gostaria que o fórum tivesse) e interpretar o conjunto da entrevista para verificar o papel que, segundo o entrevistado, o conselho de fato exerce.

O capítulo encontra-se organizado da seguinte forma: após esta introdução, segue-se uma caracterização dos conselhos municipais de Saúde da RMPA, no que tange ao período de criação, aos tipos de conselheiros que integram os fóruns - utilizando a mesma tipologia já empregada nos capítulos anteriores - e às condições de infra-estrutura para o seu funcionamento. Em seguida, é abordada a dinâmica de funcionamento dos fóruns, especialmente no que se refere às relações de poder estruturadas em torno do processo de construção da agenda de debates das reuniões plenárias e à dinâmica das relações que se estabelece entre conselho e Secretaria Municipal de Saúde (SMS). Na penúltima seção, agregam-se à análise algumas considerações sobre as articulações políticas entre atores que atuam dentro e fora do conselho, buscando encontrar indicações da existência de comunidade de política atuando nos conselhos analisados ou na área da saúde. Por fim, trata-se do papel institucional do fórum no contexto da política de saúde municipal. 


\section{CaracterizaÇÃo dos ConselHos Munic IPAISDE SAÚDE DA RMPA: PERÍODO DE CRIAÇÃO, TIPOSDE CONSELHEIROS E INFRA-ESTRUTURA DE FUNCIONAMENTO}

A criação de fóruns participativos na área da saúde precedeu à edição das leis e normas do SUS, da década de 1990, que regulamentaram os conselhos de Saúde no país. Grande parte dos conselhos municipais originou-se das chamadas comissões interinstitucionais de saúde, criadas em 1984 com o Programa das Ações Integradas de Saúde e consolidadas pelo Sistema Unificado Descentralizado de Saúde (Suds), instalado em 1987. O estímulo à criação das comissões se deu por meio do condicionamento da transferência de recursos aos estados e municípios a um conjunto de exigências, dentre as quais se destacava a criação de instâncias colegiadas, nas quais deveriam participar entidades representativas da sociedade civil (Costa, 2002).

O arcabouço legal e administrativo que, a partir de 1990, criou os conselhos e conferências de Saúde e que regulamentou o seu funcionamento incidiu, portanto, sobre um processo institucional, de descentralização e implantação de mecanismos participatórios, já em curso. A disseminação dos conselhos municipais de Saúde em praticamente todos os municípios do país, entretanto, somente ocorreu de fato com a edição das normas operacionais básicas (NOBs), pelo Ministério da Saúde, em 1993 e 1996 (Brasil, 1993, 1996). A criação desses conselhos foi, novamente, um dos requisitos para o município se habilitar a gerir recursos - financeiros, físicos e humanos repassados da esfera administrativa federal para a municipal.

Analisando os conselhos de Saúde dos municípios da RMPA, constatou-se que a maior parte deles foi criada em dois períodos distintos, que sucedem à edição de legislação ou normas administrativas federais que induziam a constituição de fóruns participativos municipais. O primeiro grupo de conselhos - criados entre 1990 e 1993 - responde às determinações da lei n. 8.142 (Brasil, 1990), que estabeleceu as regras básicas sobre suas funções e composição. Conforme Silva (2004: 83), o processo de criação dos conselhos "deslanchou a partir de 1991, principalmente após a IX Conferência Nacional de Saúde em 1993, momento em que os movimentos popular e sindical exigiram do Ministério da Saúde medidas para acelerar a formação dos conselhos e a municipalização em todo o país”. 
fator determinante nesse processo foi, segundo a autora, exigência de criação de conselhos para que ocorressem transferências de recursos entre as esferas administrativas. Já o segundo período, de 1995 a 1998, é marcado pela indução promovida pela NOB/93 - que veio a ser efetivamente implantada somente no final de 1994 - e pela NOB/96. As normas operacionais regulamentaram o processo de municipalização da área da saúde, mantendo a exigência de existência de conselhos dentre as condições indispensáveis para a realização de transferências de recursos financeiros do nível federal para os níveis subnacionais de gestão.

Como pode ser observado no Gráfico 1, praticamente um terço dos conselhos municipais de Saúde da RMPA foi criado em 1991. De 1991 a 1993, foram constituídos $64 \%$ do total de conselhos municipais de saúde da Região (20 em 31). No segundo período, de 1995 a 1998, foram instituídos os demais 11 conselhos. Em 1997, verificou-se a maior concentração, no período, de conselhos criados em um ano (5 em 11). Tal situação pode estar relacionada à publicação, em novembro de 1996, da NOB/96. É possivel constatar, portanto, que de modo geral as regras legais e as normas administrativas nacionais da área estão relacionadas à criação de conselhos municipais.

Gráfico 1 - Número de conselhos municipais de Saúde criados por ano. RMPA - 1991-1998

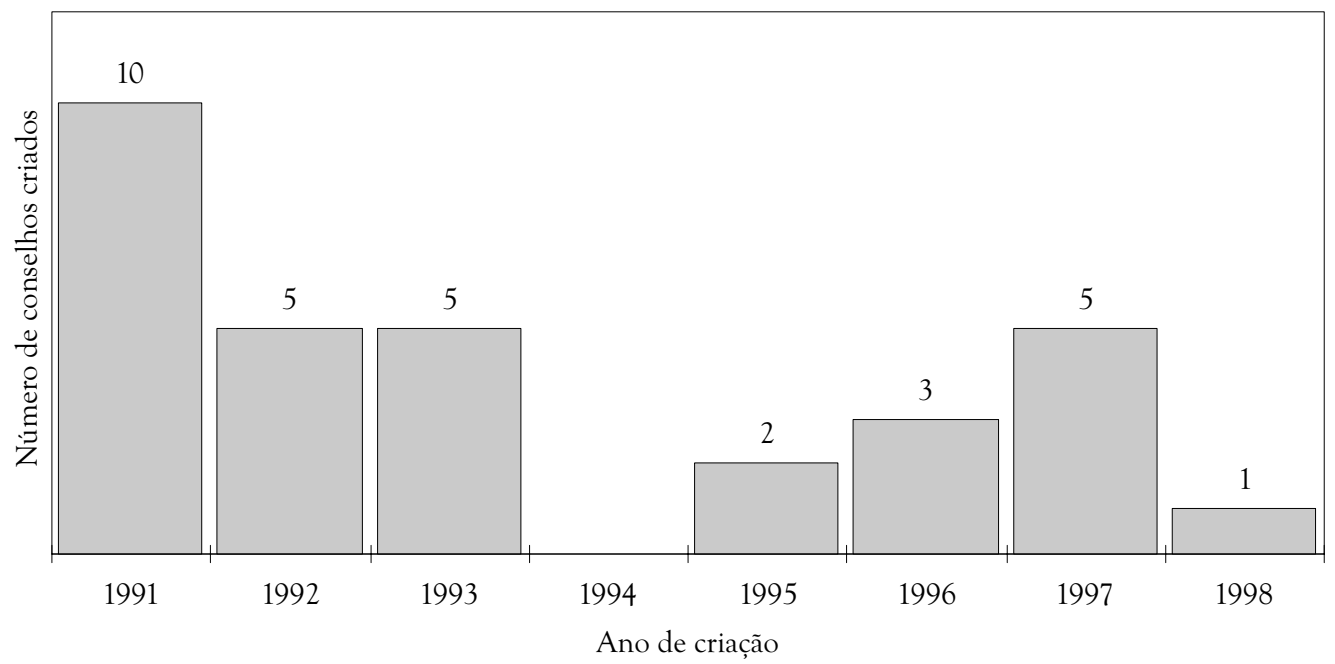

Fonte: Grupo de Pesquisas Sociedade, Participação Social e Politicas Sociais, 2007. 
No que tange à composição dos conselhos, a lei n. 8.142 (Brasil, 1990) estabeleceu que os conselhos de Saúde devem ter o número de usuários paritário em relação ao conjunto dos demais participantes - profissionais e trabalhadores de saúde, prestadores e gestores de serviços de saúde. As leis municipais que criaram cada um dos 31 conselhos da RMPA seguiram essa norma e definiram as entidades que representariam os usuários. Como, neste estudo, a análise da composição dos conselhos não seguiu as determinações legais, buscou-se verificar qual era a proporção de participantes que poderiam ser enquadrados como representantes sociais, governamentais e de mercado.

Os representantes de organizações sociais provinham de associações comunitárias, movimentos sociais e organizações não governamentais (ONGs); de entidades que defendem os interesses de portadores de patologias e deficiências; de organizações de profissionais e trabalhadores de saúde e de trabalhadores de outras áreas. Os representantes de entidades de mercado eram oriundos de associações de cunho empresarial, sindicatos patronais, instituições privadas que atuam na formação de recursos humanos para o setor saúde, bem como de entidades privadas, filantrópicas e estabelecimentos hospitalares que prestam serviços de saúde ao SUS. ${ }^{6}$ Os representantes governamentais eram procedentes de órgãos públicos responsáveis pela área da saúde no município e por outras áreas de governo, relacionadas ou não ao setor saúde.

Considerada a tipologia aqui descrita, buscou-se verificar a proporção de conselheiros provenientes de entidades sociais, governamentais e de mercado. O Gráfico 2 mostra que os representantes de entidades sociais compunham $62 \%$ do universo de conselheiros municipais de saúde na RMPA, em 2004 (497 em 801). Do universo de representantes de organizações sociais (497), a maioria era proveniente de associações comunitárias, movimentos sociais e organizações não governamentais $(55 \%, 272 \mathrm{em}$ 497). Dentre estes, predominavam representantes de associações comunitárias e de moradores (110). A segunda e a terceira categorias de representantes de organizações sociais com maior número de conselheiros eram

\footnotetext{
${ }^{6}$ Os estabelecimentos hospitalares, embora diferenciados em privados e públicos, segundo informações do endereço eletrônico do Departamento de Informática do Sistema Único de Saúde (Brasil 2007b), foram considerados como instituições de mercado, porque os hospitais públicos buscam a expansão do atendimento, competindo do mesmo modo que os privados pelos recursos públicos destinados à contratação de serviços.
} 
formadas pelos profissionais e trabalhadores de saúde e pelos trabalhadores não especificamente da área da saúde, que perfaziam 23\% (117 em 497) e $16 \%$ (78 em 497), respectivamente, do total de conselheiros provenientes de entidades sociais.

Gráfico 2 - Número e percentual de conselheiros municipais de saúde por tipo de representante. RMPA - 2005 e 2006

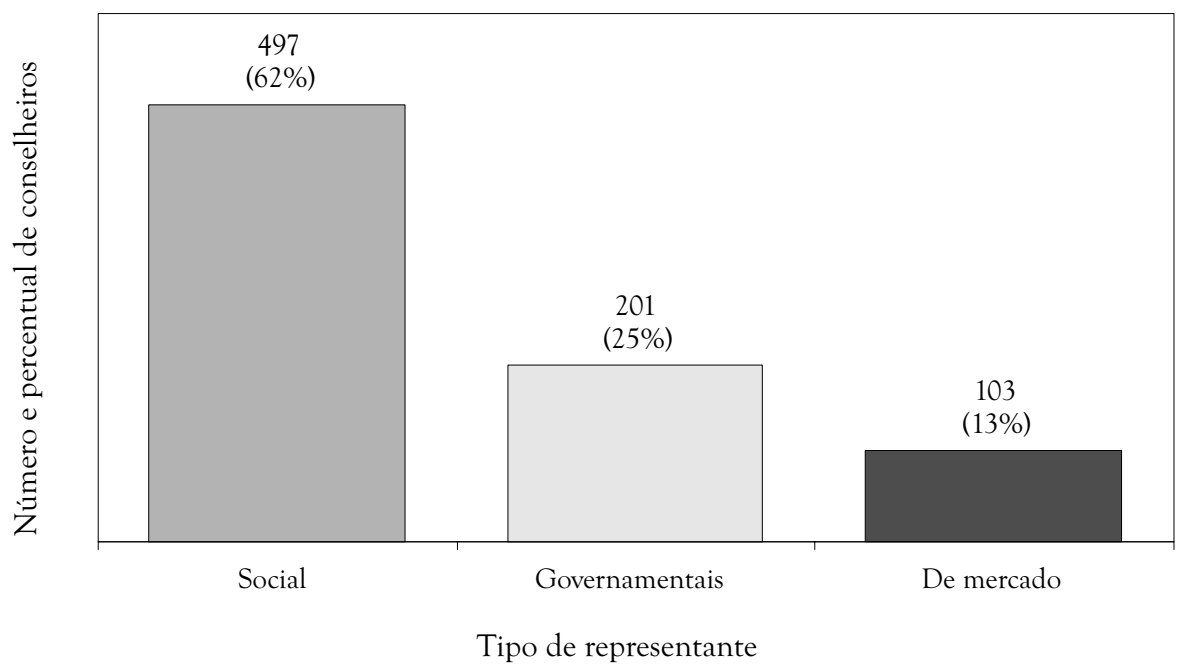

Fonte: Grupo de Pesquisas Sociedade, Participação Social e Politicas Sociais, 2007.

Os representantes governamentais correspondiam a um quarto do total de conselheiros municipais (201 em 801). Observe-se que as conferências de Saúde recomendaram que os conselhos tivessem apenas 12,5\% dos componentes provenientes de órgãos de governo. A relativa sobre-representação de conselheiros governamentais, se aliada a outras indicações, tais como controle sobre a formação da agenda e coordenação de instâncias decisórias internas, pode indicar a existência de hipertrofia de poder de gestores e burocracias governamentais, tendência que vem sendo mostrada por diversos autores ao analisarem fóruns participativos (Pinto, 2004; Valla, 1998a, 1998b).

Dentre eles esses representantes de órgãos governamentais, constatouse que 59\% (118 em 201) não eram oriundos da área da saúde. Entretanto, isso não quer dizer que a posição de gestores municipais de saúde no contexto das relações que se estruturavam no interior dos fóruns fosse menos influente que a de outros representantes governamentais. Ao contrário, sua 
posição era hierarquicamente superior à dos demais, tendo em vista seu papel de principal decisor municipal da área da saúde e de interlocutor fundamental para as demandas e propostas apresentadas pelos outros atores no fórum.

Os representantes de entidades de mercado correspondiam a 13\% (103 em 801) do total de conselheiros. A maioria deles representava prestadores de serviços de saúde (70\%, 72 em 103) e, dentre esses, a maior parte (67 em 72) representava estabelecimentos hospitalares privados. Isso provavelmente está relacionado ao fato de os gastos públicos em saúde terem se concentrado na contratação de serviços privados ao longo do processo de implementação do SUS (Menicucci, 2004). Por sua vez, os dirigentes de hospitais públicos, representados nos conselhos por apenas cinco conselheiros (em 72), podiam recorrer a canais mais diretos na gestão pública tanto para buscar informações como para apresentar suas demandas (Gráfico 3).

Os fóruns nos quais esses conselheiros atuavam apresentavam condições pouco adequadas para um funcionamento que permitisse uma relativa autonomia em relação ao gestor municipal de saúde. Verificou-se que a maioria dos conselhos (64\%, 20 em 31) não tinha local próprio para desenvolver as atividades administrativas e que mais da metade deles (52\%, 17 em 31) não contava com funcionário para as atividades de secretariado. É raro encontrar no quadro de pessoal das prefeituras um cargo público específico para essa função. Assim, eles eram cedidos para trabalhar no conselho de Saúde, de forma exclusiva ou para trabalhar ao mesmo tempo em vários conselhos municipais de políticas públicas, tendo inclusive, algumas vezes, que seguir realizando as atividades administrativas próprias de seu cargo (S. J., entrevista, 22/9/2006).

Sobre os locais de reunião, ${ }^{7} 61 \%$ dos entrevistados (56 em 92) se referiram a espaços pertencentes ao órgão responsável pela gestão da saúde no município (35) ou a outros órgãos do executivo municipal (21). Apenas 13\% (12 em 92) mencionaram a existência de sede própria na qual funcionava o conselho ou conselhos municipais variados. A realização das reuniões em espaços temporariamente cedidos pela prefeitura dificultava uma atuação mais ativa e independente do conselho (J. R., entrevista, 13/10/2005).

\footnotetext{
${ }^{7}$ A classificação de locais de reunião utilizada foi a seguinte: 'sede própria', quando o conselho dispunha de dependências próprias ou dividia um mesmo espaço físico com outros conselhos de politicas públicas; 'gestor de saúde', quando a reunião ocorria em dependências sob a responsabilidade do gestor de saúde municipal; 'governo', no caso de o local pertencer a órgão do governo municipal, que não da área da saúde; 'legislativo' municipal; 'entidade', quando a reunião ocorria em sedes de sindicatos de trabalhadores, de associações de bairro, de organizações sociais e religiosas.
} 
Gráfico 3 - Número e percentual de conselheiros municipais de Saúde pela categoria de representante. RMPA - 2005 e 2006

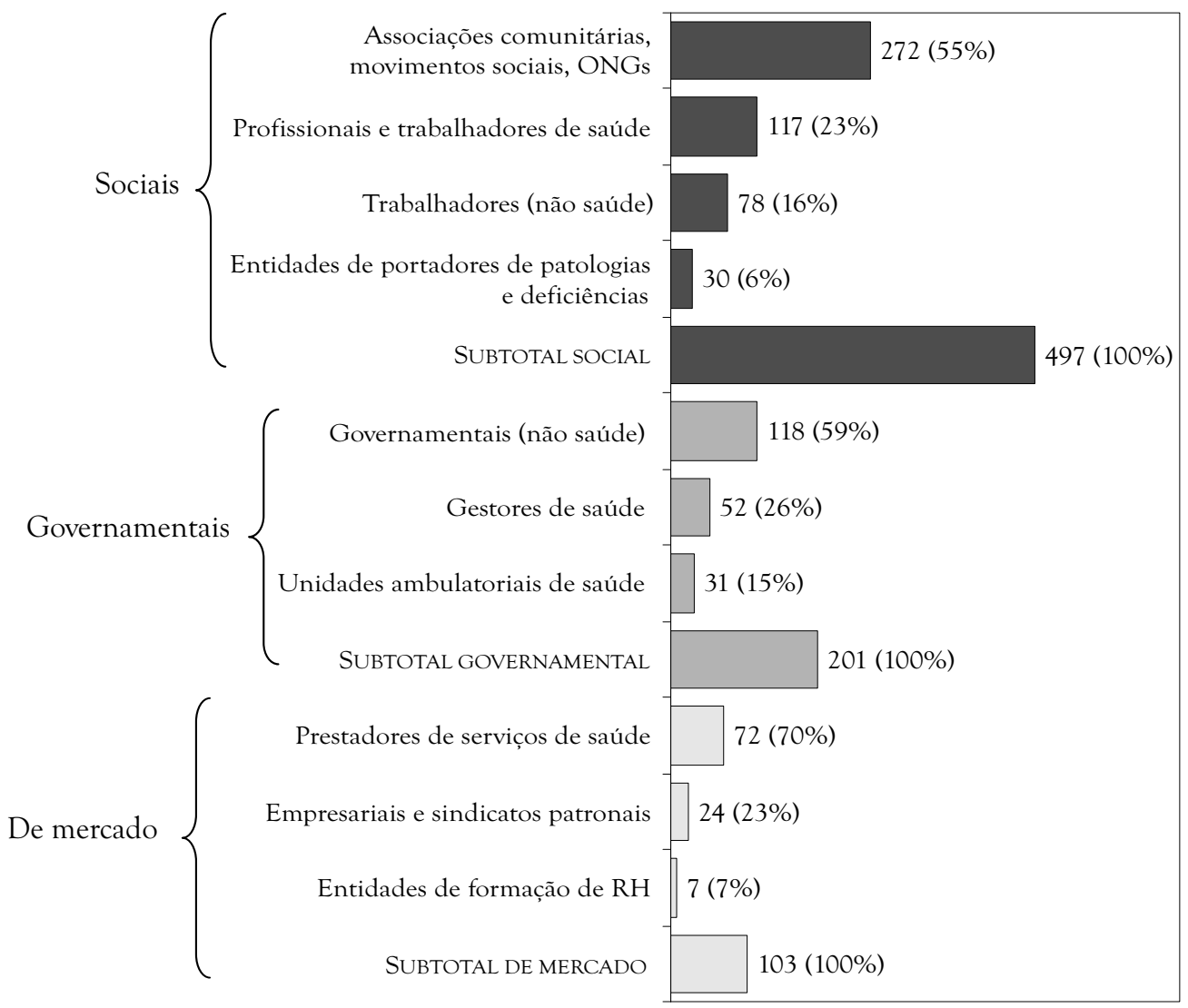

Fonte: Grupo de Pesquisas Sociedade, Participação Social e Politicas Sociais, 2007.

O grupo que dirigia a prefeitura e o órgão responsável pela área da saúde municipal podia optar por oferecer ou não apoio, na forma de recursos financeiros, físicos e humanos, para viabilizar o melhor funcionamento do conselho. No caso dos conselhos analisados, a falta de condições de infra-estrutura pode, por um lado, ser um indicativo de que os atores governamentais municipais não estavam particularmente interessados em fazê-lo; por outro, pode sugerir que os atores sociais, que tinham a maioria nos plenários dos conselhos, não dispunham de recursos de poder para pressionar o gestor a viabilizar a melhoria das condições de infra-estrutura dos fóruns ou, então, não colocavam o bom funcionamento do conselho entre suas prioridades. 
Na próxima seção, é examinada a dinâmica de funcionamento dos fóruns buscando identificar, por meio dela, como se estruturavam as relações entre os atores dentro dos conselhos municipais.

\section{DinÂMICA dE FUnCIONAMENTO DOS CONSELHOS MUNICIPAIS DE SAÚDE DA RMPA}

Com o objetivo de obter indicações sobre a existência de uma configuração típica das relações sociais nos conselhos, foram analisados os seguintes aspectos de sua dinâmica de funcionamento: 'periodicidade, turno de realização, duração, etapas que compunham as reuniões plenárias'; 'processo de elaboração da pauta'; 'coordenação das reuniões plenárias'; e 'tipo de relação existente entre conselho e gestor municipal de saúde'. A periodicidade, o turno de realização, a duração e as etapas que compunham as reuniões plenárias permitem que se visualize como transcorriam as reuniões. $\bigcirc$ processo de elaboração da pauta, o exercício da coordenação das reuniões plenárias e o tipo de relação entre conselho e gestor municipal de saúde oferecem indicações sobre como se estruturavam as relações entre os atores estatais e sociais nos fóruns. Estes últimos indicadores foram examinados focalizando eventuais assimetrias nas relações entre os atores, que permitiam a alguns hegemonizar o processo decisório nos conselhos.

Segundo os entrevistados, as reuniões ocorriam mensalmente $(47 \%, 43$ em 92), no turno da noite (72\%, 66 em 92), e tinham duração de uma a duas ou de duas a três horas (50\% e 48\%; 46 e 44 em 92, respectivamente). A média de tempo gasto para a realização das reuniões oscilava, para mais ou para menos, conforme a pauta do dia. As reuniões mais demoradas eram aquelas em que havia denúncias de falta de medicamentos, de má qualidade do atendimento ou análise da prestação de contas do gestor, de forma que a duração tendia a variar de acordo com o "tempo necessário para a discussão de cada assunto" (G. H., entrevista, 30/6/2006). Os integrantes dos conselhos eram convocados para as reuniões plenárias pelo correio ou por telefone. ${ }^{8}$ A lista de presença era assinada pelos conselheiros antes da reunião e durante o seu transcurso. Uma vez iniciada a reunião, as etapas subseqüentes

\footnotetext{
${ }^{8}$ Em relação ao recebimento da pauta, 39\% dos entrevistados (36 em 92) acusaram o recebimento com antecedência, o que ocorria geralmente com a convocação para a plenária, em um prazo que variava de uma semana a 72 horas antes da reunião. Apenas três conselheiros disseram não haver envio da pauta com antecedência.
} 
apontadas de forma mais recorrente pelos conselheiros entrevistados mantinham a seguinte ordem: 1) verificação de quorum; 2) abertura; 3) comunicações; 4) avaliação da ata da reunião anterior; 5) pontos específicos de pauta; 6) assuntos gerais; 7) informes e 8) encerramento. As duas etapas que concentravam a maior parte dos debates eram a quinta e a sexta. Na quinta - 'pontos específicos de pauta' - ocorriam as principais discussões. A apresentação de cada ponto de pauta geralmente envolvia a exposição de relatórios de comissões de trabalho do conselho ou a presença de não conselheiros, que detalhavam aspectos técnicos de projetos, relatórios, endemias, patologias.? Na etapa 'assuntos gerais', havia a manifestação de conselheiros e de participantes não conselheiros, especialmente de pessoas da comunidade local, que traziam denúncias ao conselho. ${ }^{10}$

Embora a pauta fosse previamente elaborada e servisse como o guia fundamental dos trabalhos durante a reunião plenária, segundo a maioria dos entrevistados (70\%, 64 em 92) era possível modificá-la durante a reunião. As alterações - na ordem das discussões ou então inclusão ou exclusão de assuntos a serem debatidos - podiam ser propostas por conselheiros ou, mesmo, por participantes externos. ${ }^{11}$

Um dos principais indicadores de poder de influência sobre a dinâmica de funcionamento de um fórum é o modo como é elaborada sua agenda de debates, expressa na pauta das reuniões. Tal elaboração que envolve a seleção dos assuntos a serem discutidos tem o potencial de indicar quem controla a dinâmica de funcionamento do fórum. $\bigcirc$ Gráfico 4 mostra que, dentre os 92 entrevistados, 37\% (34) indicaram o presidente do conselho como participante fundamental no processo de definição da pauta; 33\% (30 em 92) destacaram o papel da SMS nesse processo e 30\% (28 em 92) se referiram à Mesa Diretora. ${ }^{12}$

\footnotetext{
${ }^{9}$ Dentre os entrevistados, nove mencionaram tal procedimento como freqüente (F. H., entrevista, 13/9/2005; G. H., entrevista, 30/6/2006; L. E., entrevista, 27/10/2005; M. A., entrevista, 30/10/2005; M. D., entrevista, 4/11/2005; O. G., entrevista, 10/8/2005; Q. H., entrevista, 19/9/2006; S. D., entrevista, 17/10/2005; T. L., entrevista, 30/3/2006).

10 Tais manifestações foram referidas por oito entrevistados (B. C., entrevista, 10/10/2005; C. R., entrevista, 4/7/2006; D. L., entrevista, 29/8/2005; F. R., entrevista, 20/6/2005; G. H., entrevista, 30/6/2006; P. M., entrevista, 4/10/2006; O. L., entrevista, 21/6/2006; S. S., entrevista, 14/6/2006).

${ }^{11}$ A possibilidade de participantes externos interferirem na pauta foi mencionada mais de uma vez por oito entrevistados (A. L., entrevista, 23/8/2005; G. A., entrevista, 14/10/2005; G. P., entrevista, 29/9/2005; L. M., entrevista, 6/9/2005; N. D., entrevista, 8/12/2005; R. B., entrevista, 30/6/2006; R. L., entrevista, 14/9/2005; T. L., entrevista, 30/03/2006).

12 Em alguns conselhos, a Mesa Diretora é chamada de 'núcleo de coordenação'.
} 
Gráfico 4 - Número e percentual de participantes ou instância dos conselhos municipais de Saúde envolvidos na elaboração da pauta, por entrevistado. RMPA - 2005 e $2006^{*}$

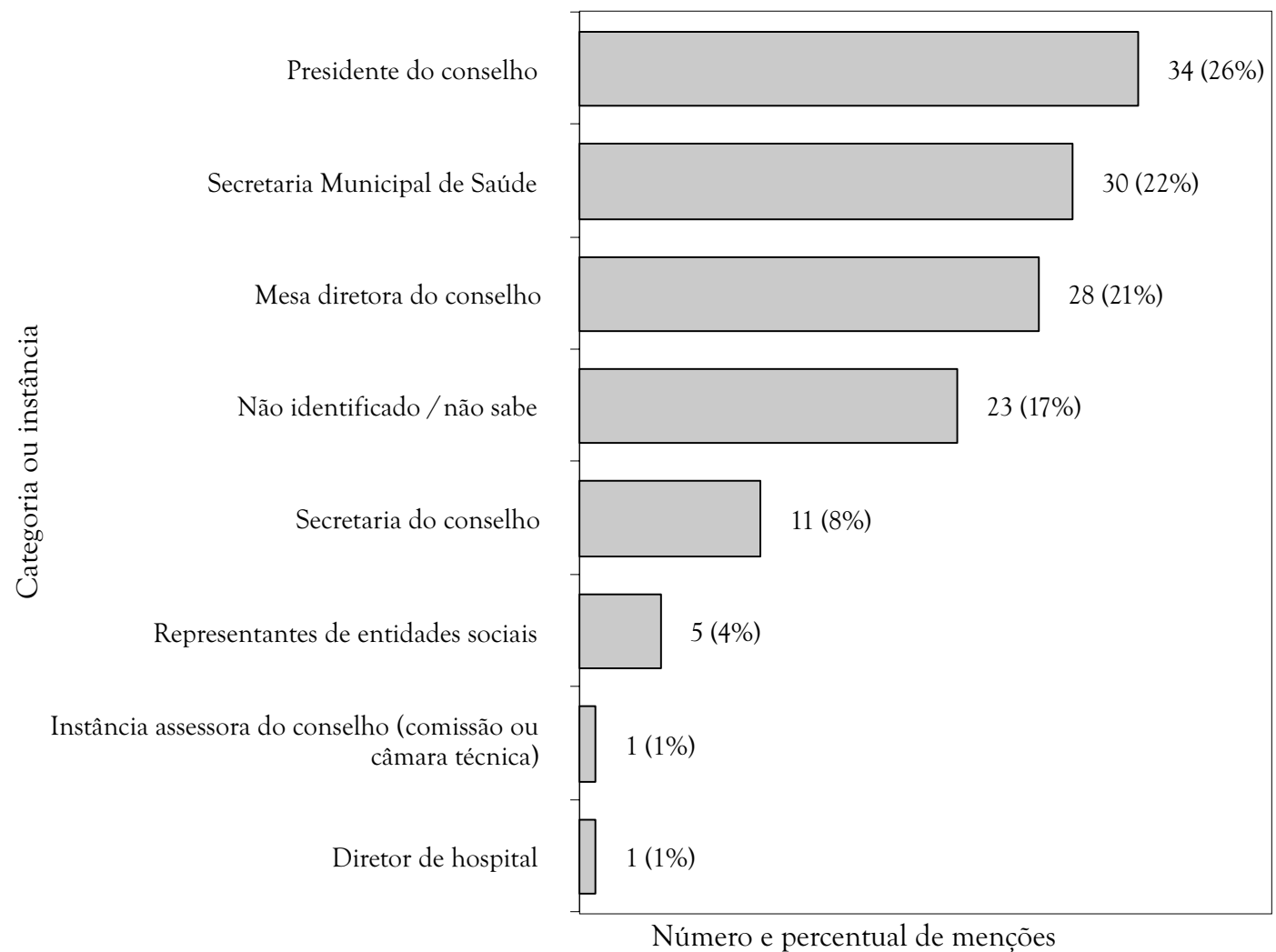

* Um entrevistado poderia mencionar mais de um tipo de participante influindo sobre a formação da agenda.

Fonte: Grupo de Pesquisas Sociedade, Participação Social e Politicas Sociais, 2007.

Esses dados podem conduzir a duas interpretações. A primeira é que os atores sociais participavam ativamente na definição da pauta, pois eles freqüentemente exerciam a presidência dos fóruns e integravam as mesas diretoras. Há coincidência entre os resultados das entrevistas e a literatura, ao indicarem que a presidência dos conselhos de Saúde na RMPA era ocupada predominantemente por conselheiros provenientes de entidades sociais. Os representantes de organizações sociais eram presidentes de 
conselhos para 50\% dos entrevistados (46 em 92), ${ }^{13}$ provinham de órgãos governamentais para 14\% (14 em 92) e de entidades de mercado para 11\% (dez em 92) deles. O Observatório da Escola Nacional de Saúde Pública Sergio Arouca (Ensp) sobre o perfil dos conselhos chegou a conclusão similar, atestando que, em 2006, 55\% dos conselhos da RMPA tinham na presidência conselheiros oriundos de entidades sociais (Ensp, 2007). Além disso, como representantes dessas entidades podiam integrar as Mesas Diretoras, pode-se supor que eles se envolviam também no processo de formação da pauta principalmente como componente de instâncias de direção dos fóruns.

A segunda interpretação é que os gestores municipais de saúde contribuíam de forma decisiva para a formação da agenda de debates dos fóruns. Embora apenas 15\% dos entrevistados (14 em 92) apontem o gestor como presidente do conselho e o Observatório da Ensp informe que apenas 10\% desses conselhos são dirigidos por gestores, também a eles estava aberta a possibilidade de integrarem as mesas diretoras. Além disso, eles foram mencionados por 33\% dos entrevistados como envolvidos diretamente na elaboração da pauta das reuniões plenárias. Segundo os entrevistados, portanto, os gestores de saúde municipais não apenas influíam na formação da agenda de debates participando em instâncias decisórias dos conselhos, mas também exerciam controle direto sobre sua definição.

De acordo com os entrevistados, os dois tipos de atores intervinham de modo diferente sobre a elaboração da pauta. Os representantes dos gestores de saúde eram responsáveis pela inclusão na pauta da maior parte dos assuntos a serem debatidos. Eles ocupavam papel central nas discussões. Cabia a eles, ou a técnicos por eles designados, o esclarecimento de dúvidas sobre questões financeiras ou relacionadas à administração de serviços de saúde, à situação da saúde no município e às políticas e ações de saúde. Além disso, os atores governamentais, vinculados ou não à área da saúde, eram responsáveis pelo encaminhamento das decisões tomadas nos conselhos. Aos conselheiros provenientes de organizações sociais cabia o poder de veto sobre propostas trazidas à discussão pelos representantes

\footnotetext{
${ }^{13}$ Dentre esses 46 respondentes que afirmaram que os conselhos eram presididos por representantes de entidades sociais, vinte identificaram o presidente como integrante da categoria associações comunitárias, movimentos sociais e ONGs; nove como representante de entidades de profissionais e trabalhadores de saúde; e nove como conselheiros oriundos de entidades de trabalhadores não especificamente da área da saúde.
} 
governamentais e, também, por entidades de mercado que poderiam contrariar seus interesses ou os valores que defendiam. ${ }^{14}$

A coordenação das reuniões é outro indicador interessante para comparar a importância relativa de determinado tipo de ator na condução dos trabalhos e no processo decisório de conselhos. Segundo $85 \%$ dos entrevistados (78 em 92), a coordenação cabia ao presidente. Para 50\% desses mesmos respondentes (46 em 92), quem presidia o fórum representava organizações sociais. Como parece haver relação entre o ato de coordenar reuniões e o exercício da presidência dos fóruns, é possivel supor que tal predominância fosse peculiar aos conselhos de Saúde dos municípios da RMPA. Tal suposição é possível porque o mesmo Observatório da Ensp (Ensp, 2007) que confirma essa tendência nos conselhos da RMPA, indicando uma proporção de 55\% dos conselhos na Região, em 2006, presididos por representantes de organizações sociais, também mostra que situação semelhante ocorria em apenas 15\% dos conselhos municipais no país (Moreira et. al., 2006). A presença mais constante de representantes da sociedade civil na direção dos conselhos na RMPA provavelmente está relacionada aos padrões altos de associativismo e interesse por política verificados na Região.

No entanto, isso não quer dizer que a participação de atores estatais e, dentre eles, principalmente a dos gestores municipais de saúde não fosse decisiva para o modo como eram conduzidos os trabalhos nos conselhos. A importância dessa participação é atestada não apenas pela influência desses atores sobre a formação da agenda dos fóruns, mas também pelo modo como os entrevistados caracterizam a natureza das relações entre gestores e conselhos. Como mostra o Gráfico 5, entre os entrevistados havia uma leve preponderância de uma visão negativa sobre tais relações, com 55\% dos entrevistados (51 em 92) salientando os entraves que se interpunham entre conselho e gestor e 47\% (43 em 92) caracterizando-as como positivas. A visão negativa estava associada a apreciações sobre falta de prazo adequado para as discussões e à ausência de condições apropriadas para o funcionamento do fórum. Assim, para os respondentes cabia aos gestores de saúde viabilizar ou obstaculizar os trabalhos dos conselhos.

\footnotetext{
${ }^{14} \mathrm{O}$ função de 'veto' dos representantes de entidades sociais foi mencionada por 15 entrevistados (A. L., entrevista, 23/8/2005; A. J., entrevista, 29/12/2005; B. A., entrevista, 19/12/2005; B. O., entrevista, 5/12/2005; C. A., entrevista, 21/10/2005; F. I., entrevista, 15/6/2005; F. R., entrevista, 20/6/2005; G. A., entrevista, 14/10/2005; I. L., entrevista, 24/6/2005; L. E., entrevista, 27/10/2005; N. D., entrevista, 8/12/2005; O. L., entrevista, 21/6/2006; R. B.,entrevista, 30/6/2006; S. D., entrevista, 17/10/2005; T. C., entrevista, 7/10/2006).
} 
Gráfico 5 - Número e percentual de tipos de visão sobre as relações existentes entre conselhos municipais de Saúde e gestão municipal de saúde, por entrevistado. RMPA - 2005 e 2006

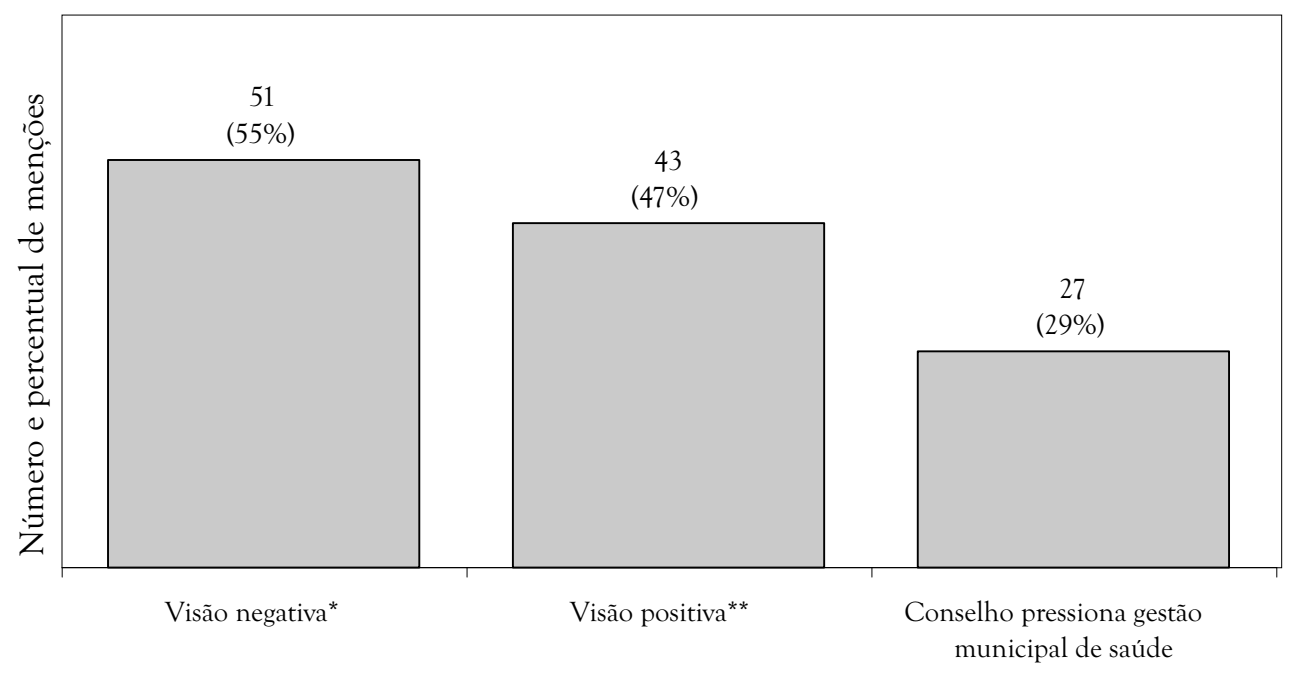

Tipo de visão

* Falta de prazo para discussões/votações, desrespeito a decisões do conselho, falta de infraestrutura de apoio, existência de entraves na relação, interferência na composição do conselho, desinteresse em estimular participação, gestor ausente, a SMS pressiona o CMS e a SMS oculta informações - controla a pauta.

** Boa parceria; gestores oferecem infra-estrutura de apoio ao conselho.

Fonte: Grupo de Pesquisas Sociedade, Participação Social e Politicas Sociais, 2007.

A seção seguinte focaliza a configuração de relações sociais estruturadas nos conselhos e na área da saúde dos municípios. Para isso, são analisadas as articulações, as mobilizações e os conflitos verificados entre os atores que integravam os fóruns no interior dos conselhos e na arena decisória setorial mais ampla.

\section{As Relações entre Atores no Interior dos ConselHos Munic IPAIS de SAÚde dA RMPA}

O controle do processo decisório nos conselhos municipais de Saúde da RMPA era exercido por representantes de organizações sociais e governamentais. As posições ocupadas - na configuração das relações sociais estruturadas na área e no contexto da política municipal de saúde - pelos individuos que exercem essas representações não é o resultado da legitimidade que lhes é atribuída pela condição de representantes de coletividades. 
A ocupação de posições hierarquicamente superiores nessa estrutura e de papel destacado na arena política setorial municipal era definida, por um lado, pela natureza e intensidade das conexões que eles estabeleciam com redes de atores de âmbito metropolitano, estadual e nacional; por outro, pelo domínio de certos tipos de saberes específicos e especializados (Lee $\&$ Mills, 1985; Walt, 1994). Esse é o caso de profissionais de saúde e de comunidades de políticas - as últimas agregando diferentes tipos de atores (individuais e coletivos) que compartilham concepções sobre quais devem ser os princípios que organizam a construção e a implementação de políticas setoriais, além de uma visão comum sobre os resultados das políticas. Ambos, profissionais e comunidades de política, agem na arena política através das fronteiras entre Estado e sociedade, ocupando diversos postos e exercendo diferentes funções, o que redefine constantemente a configuração das relações sociais estruturadas na própria arena de política em que atuam.

Os profissionais de saúde que agiam nos municípios da RMPA - médicos, enfermeiros, farmacêuticos, psicólogos, dentistas, assistentes sociais foram caracterizados pelos entrevistados como muito influentes não apenas nos conselhos mas também na arena decisória da política de saúde do município. Ao todo, 45\% dos entrevistados (41 em 92) se referiam a eles principalmente médicos e enfermeiros - como as pessoas mais atuantes nos municípios analisados. No entanto, a análise das entrevistas não permitiu concluir que eles - ou outros indivíduos atuantes no contexto da política de saúde municipal - participassem em comunidades de política ou que se articulassem a outros atores, grupos ou instituições.

Os entrevistados relacionavam a importância que atribuíam à atuação desses profissionais à legitimidade que reconheciam em seus conhecimentos técnicos e administrativos. O reconhecimento de um saber diferenciado e superior ao dos demais integrantes da rede de política da área ou dos conselhos é associado à expertise do indivíduo participante, e não à condição de representante de determinada categoria profissional, como expressa o seguinte trecho de entrevista:

O conhecimento médico que eles têm [faz com] que, às vezes, o conselho de Saúde está meio enrolado em certas coisas, eles entram e até o próprio presidente do conselho de Saúde pede os conhecimentos deles, e eles esclarecem às pessoas a forma de pegar o rumo das coisas. (R. L., entrevista, 14/9/2005) 
No entanto, a atuação de profissionais nos conselhos foi criticada porque, muitas vezes, assumia um cunho corporativo, de defesa de melhorias salariais (T. C., entrevista, 7/10/2006), e também pela participação tímida dos representantes oficiais das categorias de profissionais e trabalhadores de saúde. $O$ segundo tipo de crítica foi praticamente unânime entre os entrevistados.

No mesmo sentido, os $54 \%$ dos entrevistados (50 em 92) que registraram a existência de conselheiros oriundos de sindicatos de trabalhadores no plenário dos fóruns examinados criticavam sua atuação, pois se limitavam a defender os interesses específicos das categorias que representavam. Para 28\% dos respondentes (26 em 92), sua participação era inexpressiva. Somente tornavam-se ativos quando o debate, no conselho ou na área da saúde, envolvia assuntos relacionados diretamente a cada categoria e, principalmente, se o tema em discussão se referia à saúde do trabalhador (P. M., entrevista, 26/9/2006).

O afastamento do movimento sindical do debate sobre o SUS e, conseqüentemente, da luta pela defesa de seus princípios foi analisado por Menicucci (2004). Categorias que lideram o movimento sindical brasileiro, tais como metalúrgicos, bancários e funcionários públicos, estão cobertas por planos privados de saúde. Como os membros dos sindicatos dessas categorias apenas recorrem ao SUS para obtenção de serviços para os quais os planos não oferecem cobertura, não há incentivos concretos para que as direções sindicais apóiem de forma mais efetiva o sistema.

Em contraste, $43 \%$ dos entrevistados (40 em 92) ressaltaram que representantes de associações comunitárias, movimentos sociais e $\mathrm{ONG}{ }^{15}$ participavam ativamente nos debates dos conselhos e sua atuação era intensa. Eles eram responsáveis pela apresentação constante de demandas e reivindicações e pela tomada de posição sobre propostas ou projetos apresentados por outros atores societais e representantes governamentais. Não há indicações claras, entretanto, de que esses conselheiros exercessem uma posição de liderança na construção de articulações, no conselho e fora dele, na defesa de uma visão sobre como deveria ser um sistema de saúde.

Porém, segundo a maioria dos entrevistados ( $52 \%, 48$ em 92), existia a atuação articulada de conselheiros ou destes com outros atores sociais e

\footnotetext{
${ }^{15}$ Os entrevistados se referem principalmente a representantes de associações de moradores, portadores de necessidades especiais, clubes de mães e pastorais.
} 
estatais externos aos fóruns, mesmo que essa constatação fosse acompanhada de uma avaliação negativa sobre o fato. Dentre os 48 entrevistados que afirmaram haver articulações, cerca de um quarto (13 em 48) as encarava como algo reprovável, como se fossem procedimentos ilegítimos, pouco democráticos, resultantes de um convencimento político-partidário ou tecnocrático sobre determinado assunto. É como se a política e os partidos fossem essencialmente negativos. Observa-se que, como salientou Pinto (2004), essa tem sido a visão não apenas de integrantes de processos participativos, como também a de seus analistas.

Tais articulações eram descritas como relacionamentos entre conselheiros, por vezes com a inclusão de não conselheiros, com o objetivo de aprovar ou rejeitar relatórios e propostas concernentes ao funcionamento da rede de serviços de saúde financiada pelo SUS. Elas tanto podiam ocorrer antes das reuniões como serem construídas ao longo delas (G. A., entrevista, 14/10/2005; I. C., entrevista, 21/6/2005); estabeleciam-se em torno de questões específicas, não implicando adesão automática, constante e sistemática de determinados grupos - sendo que os representantes de entidades sociais tendiam a articular-se entre si (C. A., entrevista, 21/10/2005).

Assim, embora a participação de atores societais e estatais, tanto nos fóruns como fora deles, ocorresse freqüentemente de forma articulada, a transitoriedade e a natureza episódica das ações em rede não permitem que tais articulações sejam consideradas como indicadores da existência de comunidades de política. Apenas seis dos 92 entrevistados mencionaram a existência de algum tipo de rede de relações mais consistentes, que envolvessem representantes de entidades sociais e gestores municipais de saúde. A ausência de articulações capazes de engendrar mobilizações políticas intermunicipais pode estar relacionada à inexistência de uma esfera administrativa metropolitana e também às variações em termos de cultura cívica associativa, se considerados todos os municípios que compõem a RMPA, suas discrepâncias socioeconômicas e político-institucionais.

Uma vez caracterizado o papel dos diferentes atores societais e estatais e verificado se atores individuais ou coletivos atuavam em rede no âmbito dos conselhos e na arena política setorial dos municípios, procura-se, a seguir, responder à outra questão orientadora da elaboração do presente capítulo. A indagação principal agora diz respeito ao papel dos conselhos municipais de Saúde da RMPA nessa arena. 


\section{O Papel dos Conselhos Municipais de Saúde da RMPa na Arena da Poútica de Saúde Munic ipal}

Normas legais e administrativas federais e municipais estabelecem os parâmetros gerais de funcionamento dos fóruns participativos examinados. O objetivo aqui, no entanto, é identificar as regras institucionais implícitas criadas ao longo de cerca de uma década e meia de funcionamento dos conselhos municipais de Saúde na RMPA. Parte-se do pressuposto de que tais regras são resultantes de processos de interação social de atores estatais e societais, agindo dentro e em torno dos conselhos. Sua ação desenrola-se baseada em um contexto institucional e político pretérito que foi moldado, em suas características gerais, por normas legais e decisões politicas de âmbito federal. $O$ papel dos conselhos que se procura revelar não tem, portanto, caráter formal legal, mas se refere ao conjunto de funções e ações predominantemente executadas pelos conselhos na arena da politica de saúde municipal.

Um modo de aferir o papel dos conselhos é verificar sobre o que eles discutem e deliberam, ou seja, caracterizar a agenda de debates dos fóruns expressa principalmente nas pautas das reuniões plenárias. Em seções anteriores, foram identificados os atores que mais influíam na formação das pautas. Aqui se procura reconstituir a agenda de temas de discussões e deliberações, considerando que ela oferece indicações sobre tal papel. Para isso, foram utilizados dois indicadores básicos: a 'pauta típica' das reuniões plenárias e uma caracterização sobre 'o que os conselhos faziam', de fato, no contexto da política de saúde municipal.

A 'pauta típica' permite identificar os temas recorrentes nos debates dos conselhos, segundo os entrevistados. ${ }^{16}$ As respostas às perguntas referentes aos assuntos mais debatidos foram classificadas de acordo com a seguinte tipologia desenvolvida para analisar temas debatidos em reuniões de conselhos municipais de Saúde (Côrtes, 1999):17

\footnotetext{
${ }^{16}$ Embora as reuniões dos conselhos municipais de Saúde, no periodo, estejam registradas em atas, em geral elas são extremamente sucintas. A maior parte não apresenta as listas dos conselheiros presentes, e algumas delas registram apenas o horário de começo e fim das reuniões. Por isso, não foi possivel utilizá-las como fonte de informação sobre os temas que eram debatidos ou sobre os tipos de conselheiros que intervinham nas reuniões dos fóruns examinados.

${ }^{17}$ Ressalte-se que, mesmo que uma tipificação estabeleça critérios de delimitação, a linha divisória entre os tipos pode ser dúbia, e por vezes uma mesma menção a determinado assunto foi classificada em mais de um tipo de tema. O trecho a seguir é um exemplo: refere-se ao funcionamento do conselho e, ao mesmo tempo, à discussão ao financiamento. Trata-se da questão de 'liberação de verbas', com o intuito de ajudar no "deslocamento de alguém representando a secretaria, em questões do conselho" (G. A., entrevista, 14/10/2005).
} 
- Questões financeiras: discussões relacionadas a recursos financeiros, tanto rotineiras - tais como aprovações de planos de aplicação e prestações de contas - como novas modalidades de pagamento por serviços ou debates sobre o orçamento das esferas de governo.

- Questões locais e particulares: debates sobre problemas de saúde ou de serviços de saúde localizados ou individuais, tais como a necessidade de um determinado profissional ou a falta de determinado medicamento em uma unidade de saúde particular (que não seja de referência), ou denúncia de usuário.

- Organização dos serviços, política e atenção à saúde: questões relacionadas à organização dos serviços no município, tais como discussões e decisões sobre planos, projetos e propostas que possam afetar as condições de saúde e de funcionamento dos serviços de saúde na cidade; inclui discussões sobre contratação, credenciamento e celebração de convênios que envolvam recursos do setor público, bem como descredenciamento, suspensão de contratos, abertura e fechamento de serviços de saúde.

- Funcionamento do conselho e controle social: debates relativos à criação ou à mudança de regras e de dinâmica de funcionamento do conselho, de conferências e outros fóruns participativos da área da saúde; inclui definições quanto à composição dos fóruns e à escolha de membros para representar o conselho em eventos ou em outras instituições.

Conforme o Gráfico 6, para 92\% e $85 \%$ dos entrevistados (85 e 78 em 92), assuntos relacionados ao tema 'organização dos serviços, política e atenção à saúde', assim como a 'questões financeiras', respectivamente, estavam sempre presentes nos debates, enquanto os temas 'questões locais e particulares' e 'funcionamento do conselho e controle social' foram mencionados como muito freqüentes por $52 \%$ e $41 \%$ dos entrevistados, respectivamente (48 e 38 em 92). No entanto, na percepção de $50 \%$ dos respondentes (46 em 92), a temática 'organização dos serviços, politica e atenção à saúde' não era a que tomava o maior tempo das discussões, e sim as 'questões financeiras', que envolviam demoradas discussões sobre destinação de verbas, avaliação e aprovação de projetos e prestação de contas. Os assuntos financeiros envolvem um jargão específico, proveniente da área das contas públicas, e um conjunto de procedimentos regidos por normas legais sobre como prever gastos, como 
realizá-los e como prestar contas, os quais tornam as discussões mais longas e detalhadas. ${ }^{18}$

Gráfico 6 - Número e percentual de menções por tipos de temas que integravam a pauta das reuniões plenárias dos conselhos municipais de Saúde, por entrevistado. RMPA - 2005 e 2006

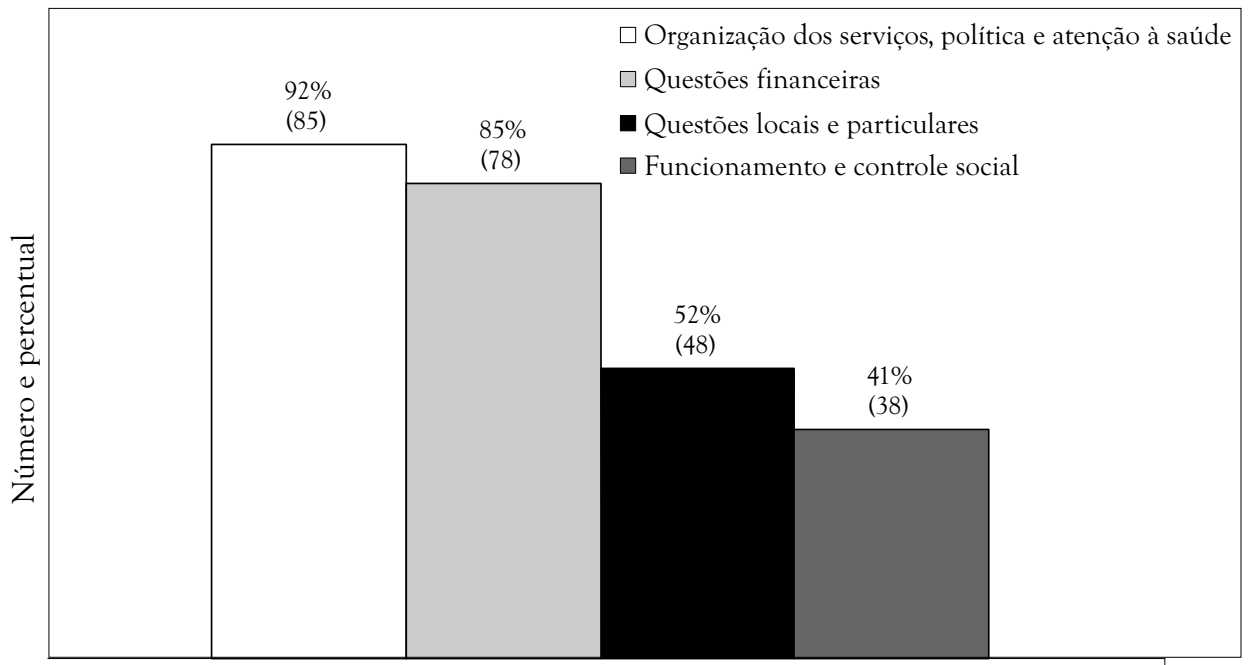

Tipo de tema

Fonte: Grupo de Pesquisas Sociedade, Participação Social e Politicas Sociais, 2007.

Constatou-se, portanto, que os conselhos predominantemente discutiam assuntos relacionados à 'organização dos serviços, política e atenção à saúde', mas que os pontos de pauta que provocavam discussões mais extensas estavam afetos a 'questões financeiras'.

As seções anteriores mostraram que as decisões nos conselhos muitas vezes eram tomadas sem o tempo adequado de discussão e que o suporte administrativo a eles oferecido nem sempre era adequado para o seu melhor funcionamento. Mas, ao mesmo tempo, segundo seus participantes, os conselhos municipais de Saúde da RMPA debatiam temas centrais da gestão em saúde das cidades.

\footnotetext{
${ }^{18}$ Entretato, a discussão sobre questões financeiras está interligada a decisões politicas sobre em que aplicar os recursos; portanto, apresenta interfaces constantes com assuntos relacionados à organização e à prestação de serviços de saúde nos municípios. Os dois conjuntos de temas relacionados à organização dos serviços, politica e atenção de saúde e questões financeiras - que concentravam as menções dos entrevistados nos dois indicadores de natureza da agenda aqui analisados provavelmente eram, muitas vezes, debatidos em conjunto.
} 
Outro modo de verificar o papel que os fóruns desempenhavam na arena política setorial envolveu a caracterização do que os conselhos faziam, ou seja, de quais eram, de fato, as suas funções nessa arena. Para isso, foi criada uma nova tipologia para classificar as menções dos entrevistados, composta pelas seguintes categorias:

- Fiscalização: assume postura de vigilância quanto à destinação de verbas e debate o financiamento das ações; fiscaliza a qualidade dos serviços e da própria gestão pública.

- Deliberação sobre política: debate amplamente assuntos de política de saúde; discute os assuntos antes de aprovar ou reprovar propostas trazidas ao debate; discute reivindicações, demandas e proposições apresentadas à gestão, independentemente de sua efetividade final.

- Instrumento formal de gestão: ratifica apenas decisões já tomadas por outros atores, em outros lugares; legitima propostas dos gestores públicos; cumpre exigência legal.

- Canal estatal: por meio do conselho, demandas societais - reivindicações e proposições - são apresentadas aos gestores públicos.

- Informativa/educativa: divulga informações em saúde, especialmente aquelas relativas a dados do município, à gestão em saúde na cidade, a eventos ou campanhas na área da saúde e a ações e propostas do próprio conselho.

- Decisão sobre controle social: trata de questões relativas a conselhos distritais e locais; escolhe os conselheiros para representar o conselho em eventos externos; conceitua instâncias assessoras ao conselho; organiza conferências de Saúde que ocorrem no município; trata das normas de eleição de Mesa Diretora e de presidente do fórum e de alterações na dinâmica de votação.

- Cartorial: decide sobre contratação, credenciamento e descredenciamento de prestadores e celebração de convênios que envolvam recursos públicos.

O Gráfico 7 mostra que a maioria dos entrevistados afirmou que os conselhos exerciam as funções de 'fiscalização' (64\%, 59 em 92) e de 'deliberação sobre política’ de saúde (52\%, 48 em 92). A primeira aparecia associada às atividades de fiscalizar o uso dos recursos financeiros na área (47 em 59), a qualidade do atendimento em saúde na cidade, especialmen- 
te no âmbito do SUS (36 em 59) e a gestão pública (30 em 59). A segunda estava relacionada à existência de discussões anteriores às votações (44 em 48); à formulação e ao encaminhamento de propostas para avaliação (33 em 48); e aos debates sobre a política de saúde, muitas vezes em confronto com os gestores municipais. Em relação ao último ponto, os entrevistados (26 em 48) destacaram o poder de veto do conselho, que podia rejeitar projetos e a inclusão de pontos de pauta sugeridos pelo gestor e impedir ou, pelo menos, atrasar a transferência de recursos financeiros para os municípios. Ou seja, o conselho "se não aprovar as contas da Secretaria de Saúde, (...) ele me tranca os repasses e se tranca os repasses eu não vou poder prestar a assistência à saúde pra população" (G. H., entrevista, 30/6/2006).

A visão de que os conselhos eram meros "instrumentos formais de gestão" foi mencionada por quase metade dos entrevistados (42\%, 39 em 92). A percepção aqui expressa sobre a atuação dos conselhos era negativa, considerando que não estariam desenvolvendo "trabalho consistente" (G. P., entrevista, 29/9/2005), e que, na prática, sua função precípua era receber projetos, prestações de contas e planos de aplicação e 'aprová-los' para viabilizar a gestão. Os trechos de entrevistas se referem a situações em que o fórum era pressionado a aprovar, sem muita discussão, propostas do gestor - tais como relatórios, prestações de contas e projetos - "porque senão a Secretaria não recebe, é a chantagem da burocracia” (A. R., entrevista, 8/9/2005).

Os conselhos foram considerados um 'canal estatal' de recepção de queixas e demandas por 35\% dos entrevistados (32 em 92). Nessa acepção, os conselhos eram tidos como espaços de 'denúncias' nos quais os mais diversos atores societais, inclusive movimentos sociais, tinham voz para reclamar sobre atendimento, cobranças indevidas por serviços prestados e "se expressar, (...) nas suas demandas, nas suas reivindicações" (F. R., entrevista, 20/6/2005). 
Gráfico 7 - Número e percentual de tipos de papel atribuídos aos conselhos municipais de Saúde, por entrevistado. RMPA - 2005 e 2006

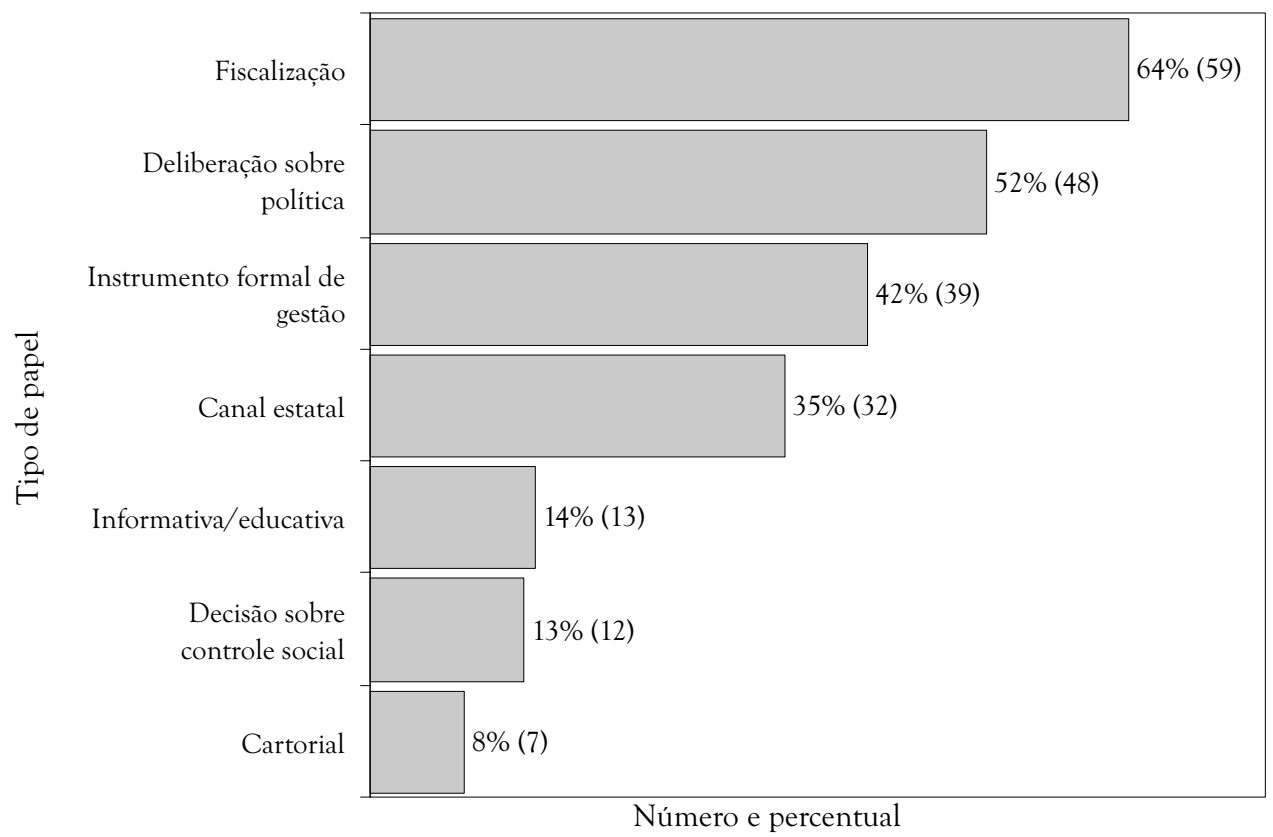

Fonte: Grupo de Pesquisas Sociedade, Participação Social e Politicas Sociais, 2007.

Concluiu-se, nesta seção, que a maioria dos entrevistados considerava que os conselhos municipais de Saúde da RMPA desempenhavam papéis de 'deliberação sobre política de saúde' e de 'fiscalização'. Tais funções podem ser vistas como compativeis com fóruns que, segundo a maioria dos entrevistados, concentravam suas discussões sobre assuntos relacionados à 'organização dos serviços, política de saúde e atenção à saúde' e a 'questões financeiras'.

Os entrevistados associavam à noção de 'deliberação' os debates que antecediam as votações, as cobranças por melhores serviços e a formulação de propostas. A idéia de deliberação, portanto, não está relacionada a uma suposta decisão sobre o conjunto das políticas da área nesse nível de gestão; a noção está vinculada ao modo como as decisões eram tomadas, mediante discussão e votação que expressa a vontade da maioria dos conselheiros. Os conselheiros podiam apresentar reivindicações e propostas diretamente ao gestor, as quais, se legitimadas pela maioria dos votos, teriam maiores chances de serem levadas em conta. Assim, os conselhos deliberavam, mas apenas o 
faziam ao tratar das questões que constavam de sua pauta de discussões, a qual era formada sob a influência de atores sociais e, principalmente, governamentais, com destaque, dentre estes, para os gestores municipais de saúde.

p papel fiscalizador dos conselhos era relacionado à idéia de fiscalizar ou controlar o destino de verbas e o financiamento em saúde, a qualidade do atendimento prestado e as ações do gestor público. A forte indução do Ministério da Saúde, no que diz respeito ao desenho das políticas do setor, e o conseqüente engessamento na aplicação dos recursos financeiros (Lima, 2005) não retiravam dos conselhos o papel fiscalizador do uso desses recursos em nível municipal. Ao contrário, esta parece ser uma das funções precípuas dos fóruns.

\section{Consideraçõ Es Finals}

Este capítulo tratou de caracterizar o modo como atores estatais e societais participavam no processo decisório dos conselhos municipais de Saúde da RMPA e da arena política setorial e, também, de verificar que papel eles desempenhavam nessa arena. As normas legais e administrativas federais podem ser consideradas como um fator decisivo na criação e na organização de conselhos municipais. Mas não são condição suficiente para estabelecer as regras tácitas que caracterizam o modo de funcionamento e o papel exercido, de fato, por esses fóruns no contexto da área de saúde municipal. Em um contexto institucional de crescimento do peso relativo dos municípios como financiadores e gestores de políticas sociais, fóruns municipais podem tornar-se atraentes à participação. As próprias mudanças institucionais que revalorizaram os governos municipais podem estar influenciando atores políticos a buscarem a participação nos conselhos municipais de políticas públicas, vistos como espaços onde podem ocorrer decisões sobre o planejamento e a implementação das políticas de saúde, em nível local.

A criação de mecanismos participativos no quadro geral de mudanças sociopolíticas e institucionais da década de 1990 resultou na conformação legal e formal de espaços políticos em estreita relação com os órgãos públicos da área da saúde. Tais mecanismos participativos passaram a atuar como vigilantes dos recursos e das aplicações orçamentárias, como espaços de debate sobre os serviços de saúde oferecidos e sobre a política setorial, e muitas vezes na defesa dos princípios fundadores do SUS, tão caros ao 
movimento sanitário. No entanto, não foi possível depreender do relato dos entrevistados que uma articulação de atores estatais e societais, a qual se assemelhasse a uma comunidade de política, atuasse no âmbito dos conselhos ou da arena política da área, nos municípios e na RMPA.

$\bigcirc$ que se observou foi a expressiva presença de atores sociais e governamentais, especialmente gestores municipais de saúde, não apenas na composição legal dos fóruns, mas também nas suas instâncias decisórias e no processo de formação de suas agendas. O número de representantes de organizações sociais (497) era superior em comparação à soma de representantes governamentais e de entidades de mercado (304) na composição do plenário dos conselhos. Os conselheiros provenientes de entidades sociais tinham presença marcante nas discussões que ocorriam nas reuniões, na ocupação da presidência dos fóruns, na definição das pautas e na composição das instâncias de direção do fórum. Não se pode desconsiderar que a relativa predominância de representantes de entidades sociais nos conselhos examinados esteja relacionada à peculiaridade da RMPA, em termos do alto grau de associativismo ali observado. Além disso, há que se levar em conta a presença significativa de conselheiros governamentais influindo sobre as condições de infra-estrutura para o funcionamento dos fóruns, na definição das pautas e no próprio encaminhamento dado às decisões que ali são tomadas.

$O$ fato de terem sido instituídos como condição para o repasse de verbas do governo federal parece não impedir, de acordo com os entrevistados, que os conselhos exerçam funções deliberativas e de fiscalização. No entanto, segundo os entrevistados, o significado de deliberação relacionavase ao modo como as decisões eram tomadas, mediante discussão e votação, e ao fato de os conselheiros apresentarem reivindicações e propostas diretamente ao gestor. $\bigcirc$ papel fiscalizador dos conselhos era relacionado pelos entrevistados à idéia de fiscalizar, não apenas o destino de verbas e o financiamento em saúde, mas também a qualidade do atendimento prestado e as ações do gestor público. 


\section{REFERÊNCIAS}

BAIERLE, S. G. Um Novo Principio Ético-Político: prática social e sujeito nos movimentos populares urbanos em Porto Alegre nos anos 80, 1992. Dissertação de Mestrado, Campinas: Universidade Estadual de Campinas.

BRASIL. Lei complementar n. 20, de 1 de julho de 1974. Dispõe sobre a criação de estados e territórios.

BRASIL. Constituição da República Federativa do Brasil, de 5 de outubro de 1988.

BRASIL. Lei n. 8.142, de 28 de dezembro de 1990. Dispõe sobre a participação da comunidade na gestão do Sistema Único de Saúde (SUS).

BRASIL. Ministério da Saúde. Norma Operacional Básica do Sistema Único de Saúde (NOB-SUS) n. 01/93, de 20 de maio de 1993.

BRASIL. Ministério da Saúde. Norma Operacional Básica do Sistema Único de Saúde (NOB-SUS) n. 01/96, de 6 de novembro de 1996.

BRASIL. Ministério da Saúde. Secretaria de Gestão Participativa, 2007a. Disponível em: <http://portal.saude.gov.br/portal/saude/cidadao/area.cfm?id_area=1103>. Acesso em: 20 ago. 2007.

BRASIL. Ministério da Saúde. Datasus, 2007b. Disponível em: <http:// cnes.datasus.gov.br>. Acesso em: 7 maio 2007.

CÔRTES, S. M. V. Pautas de reuniões e participação de usuários em conselho municipal de saúde. In: CONGRESSO BRASILEIRO DE CIÊNCIAS SOCIAIS EM SAÚDE, II, 1999, São Paulo. Anais... São Paulo: Abrasco, 1999.

CÔRTES, S. M. V. Especificidade dos conselhos municipais de saúde em relação aos demais fóruns participativos brasileiros. In: CONGRESSO BRASILEIRO DE SAÚDE COlETIVA, VII, 2003, Brasília. Anais... Rio de Janeiro: Abrasco, 2003. CD-ROM.

CÔRTES, S. M. V. Arcabouço histórico-institucional e a conformação de conselhos municipais de políticas públicas. Revista Educar em Revista, 25: 143-174, 2005.

COSTA, R. C. R. Descentralização, financiamento e regulação: a reforma do sistema público de saúde no Brasil durante a década de 1990. Revista de Sociologia e Política, 18: 49-71, 2002.

ESCOLA NACIONAL DE SAÚdE PÚBLICA SERGIO AROUCA (ENSP). Perfil dos Conselhos de Saúde do Brasil, 2007. Disponível em: <www.extranet.ead.fiocruz.br/ perfil_conselho_view/script/login2.php>. Acesso em: 18 maio 2007.

FUNDAÇÃO DE ECONOMIA E ESTATÍSTICA (FEE). Resumo estatístico RS Municipios, 2007. Disponível em: <www.fee.tche.br/sitefee/pt/content/resumo/ pg_municipios.php>. Acesso em: 12 set. 2007.

GRUPO DE PESQUISAS SOCIEDADE, PARTICIPAÇÃO SOCIAL E POLÍTICAS SOCIAIS (GPPOS). Banco de dados da pesquisa Conselhos Municipais de Políticas Públicas e Direitos na Região Metropolitana de Porto Alegre. Porto Alegre: UFRGS, IFCH, 2007. 
INSTITUTO BRASILEIRO DE GEOGRAFIA E ESTATÍSTICA (IBGE), 1996. Disponivel em: <www.ibge.gov.br/home/estatistica/populacao/condicaodevida/ indicadoresminimos/suppme/analiseresultados1.shtm>. Acesso em: 16 out. 2006.

LABRA, M. E. Capital social y consejos de salud en Brasil: ¿un círculo virtuoso?. Cadernos de Saúde Pública. 18(suppl.): S47-S55, 2002.

LEE, K. \& MILLS, A. Policy-Making and Planning in the Health Sector. Londres: Croom Helm, 1985.

LIMA, L. L. Gestão da Política de Saúde no Município: a questão da autonomia, 2005.

Dissertação de Mestrado, Porto Alegre: Programa de Pós-Graduação em Sociologia, Instituto de Filosofia e Ciências Humanas, Universidade Federal do Rio Grande do Sul.

MENICUCCI, T. M. G. Público e privado na política de assistência à saúde no Brasil. In: ENCONTRO DA ASSOCIAÇÃO BRASILEIRA DE CIÊNCIA POLÍTICA (ABCP), 4, 2004, Rio de Janeiro. Anais... Rio de Janeiro: ABCP, 2004.

MOREIRA, M. R. et al. A democratização nos conselhos de saúde. Saúde em Debate, 30(73/74): 205-218, 2006.

OBSERVATÓRIO. Relatório final: como andam as metrópoles: IV Região Metropolitana de Porto Alegre. Rio de Janeiro: UFRJ-IPPUR, 2005. Disponível em: <www.observatoriodasmetropoles.ufrj.br/como_anda/ como_anda_RM_portoalegre.pdf>. Acesso em: 2 out. 2006.

PINTO, C. R. J. Espaços deliberativos e a questão da representação. Revista Brasileira de Ciências Sociais, 19(54): 97-113, 2004.

PINTO, S. G. B. Regiões Metropolitanas: obstáculos institucionais à cooperação em políticas urbanas, 2007. Tese de Doutorado, Rio de Janeiro: Programa de Pós-Graduação em Planejamento Urbano e Regional, Universidade Federal do Rio de Janeiro.

RIO GRANDE DO SUL. Constituição do Estado do Rio Grande do Sul, de 3 de outubro de 1989.

SILVA, I. G. Participação popular nas políticas públicas: a trajetória dos conselhos de saúde do Sistema Único de Saúde no Brasil. Revista de Políticas Públicas, 8(2): 75-92, jul.-dez. 2004.

SILVA, M. K. A Construção da 'Participação Popular': análise comparativa de processos de participação social na discussão pública do orçamento em municípios da Região Metropolitana de Porto Alegre/RS, 2001. Tese de Doutorado, Porto Alegre: Programa de Pós-Graduação em Sociologia, Instituto de Filosofia e Ciências Humanas, Universidade Federal do Rio Grande do Sul.

VALLA, V. V. Sobre participação popular: uma questão de perspectiva. Cadernos de Saúde Pública, 14(2): 7-18, 1998a.

VALLA, V. V. Comentários a "Conselhos municipais de saúde: a possibilidade dos usuários participarem e os determinantes da participação”. Ciência Ė Saúde Coletiva, 3(1): 31-32, 1998b.

WALT, G. Health Policy: an introduction to process and power. Londres: Zed Books, 1994. 


\section{ENTREVISTAS}

A. J. Entrevista realizada em 29 de dezembro de 2005. Canoas. Transcrita. Arquivos GPPS/UFRGS.

A. L. Entrevista realizada em 30 de agosto de 2005. Arroio dos Ratos. Transcrita. Arquivos GPPS/UFRGS.

A. R. Entrevista realizada em 8 de setembro de 2005. Charqueadas. Transcrita. Arquivos GPPS/UFRGS.

B. A. Entrevista realizada em 19 de dezembro de 2005. Charqueadas. Transcrita. Arquivos GPPS/UFRGS.

B. C. Entrevista realizada em 10 de outubro de 2005. Montenegro. Transcrita. Arquivos GPPS/UFRGS.

B. O. Entrevista realizada em 5 de dezembro de 2005. Novo Hamburgo. Transcrita. Arquivos GPPS/UFRGS.

C. A. Entrevista realizada em 21 de outubro de 2005. Montenegro. Transcrita. Arquivos GPPS/UFRGS.

C. R. Entrevista realizada em 4 de julho de 2006. Guaiba. Transcrita. Arquivos GPPS/ UFRGS.

D. L. Entrevista realizada em 29 de agosto de 2005. Esteio. Transcrita. Arquivos GPPS/ UFRGS.

F. H. Entrevista realizada em 13 de setembro de 2005. Porto Alegre. Transcrita. Arquivos GPPS/UFRGS.

F. I. Entrevista realizada em 15 de junho de 2005. Novo Hamburgo. Transcrita. Arquivos GPPS/UFRGS.

F. R. Entrevista realizada em 20 de junho de 2005. Porto Alegre. Transcrita. Arquivos GPPS/UFRGS.

G. A. Entrevista realizada em 14 de outubro de 2005. Alvorada. Transcrita. Arquivos GPPS/UFRGS.

G. H. Entrevista realizada em 30 de março de 2006. Campo Bom. Transcrita. Arquivos GPPS/UFRGS.

G. P. Entrevista realizada em 29 de setembro de 2005. Alvorada. Transcrita. Arquivos GPPS/UFRGS.

I. C. Entrevista realizada em 21 de junho de 2005. Porto Alegre. Transcrita. Arquivos GPPS/UFRGS.

I. L. Entrevista realizada em 24 de junho de 2005. Porto Alegre. Transcrita. Arquivos GPPS/UFRGS.

J. R. Entrevista realizada em 13 de outubro de 2005. Nova Santa Rita. Transcrita. Arquivos GPPS/UFRGS.

L. E. Entrevista realizada em 27 de outubro de 2005. Cachoeirinha. Transcrita. Arquivos GPPS/UFRGS. 
L. M. Entrevista realizada em 6 de setembro de 2005. Viamão. Transcrita. Arquivos GPPS/UFRGS.

M. A. Entrevista realizada em 31 de outubro de 2005. Eldorado. Transcrita. Arquivos GPPS/UFRGS.

M. D. Entrevista realizada em 4 de novembro de 2005. Taquara. Transcrita. Arquivos GPPS/UFRGS.

N. D. Entrevista realizada em 8 de dezembro de 2005. Alvorada. Transcrita. Arquivos GPPS/UFRGS.

O. G. Entrevista realizada em 10 de agosto de 2005. Porto Alegre. Transcrita. Arquivos GPPS/UFRGS.

O. L. Entrevista realizada em 21 de junho de 2006. Novo Hamburgo. Transcrita. Arquivos GPPS/UFRGS.

P. M. Entrevista realizada em 4 de outubro de 2006. Santo Antônio da Patrulha. Transcrita. Arquivos GPPS/UFRGS.

Q. H. Entrevista realizada em 19 de setembro de 2006. Sapiranga. Transcrita. Arquivos GPPS/UFRGS.

R. B. Entrevista realizada em 30 de junho de 2005. Dois Irmãos. Transcrita. Arquivos GPPS/UFRGS.

R. L. Entrevista realizada em 14 de setembro de 2005. Charqueadas. Transcrita. Arquivos GPPS/UFRGS.

S. D. Entrevista realizada em 17 de outubro de 2006. Viamão. Transcrita. Arquivos GPPS/UFRGS.

S. J. Entrevista realizada em 22 de setembro de 2006. Triunfo. Transcrita. Arquivos GPPS/UFRGS.

S. S. Entrevista realizada em 14 de junho de 2006. São Jerônimo. Transcrita. Arquivos GPPS/UFRGS.

T. C. Entrevista realizada em 7 de outubro de 2006. Triunfo. Transcrita. Arquivos GPPS/UFRGS.

T. L. Entrevista realizada em 30 de março de 2006. Campo Bom. Transcrita. Arquivos GPPS/UFRGS. 


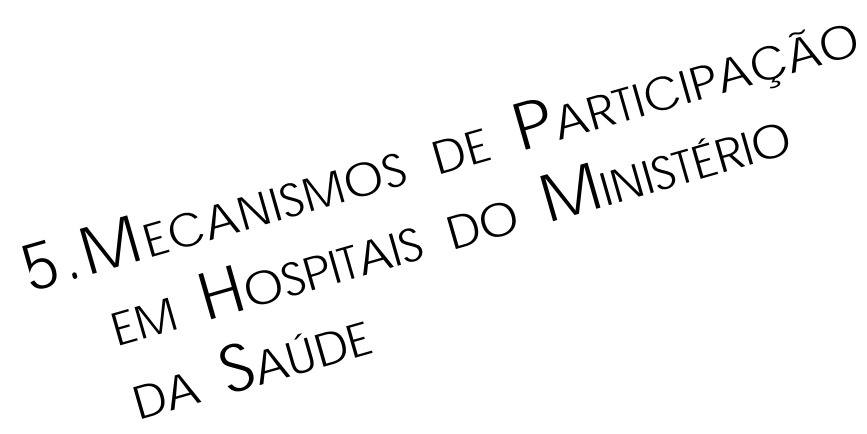

Alcindo Antônio Ferla

Lisiane Bôer Possa

Teresa Borgert Armani

Lúcia Inês Schaedler

Soraya Vargas Côrtes

\begin{abstract}
Apresenta-se neste capítulo um estudo sobre mecanismos de participação nos hospitais vinculados diretamente ao Ministério da Saúde e examinam-se os resultados do estudo empírico que identificou mecanismos, dispositivos e tecnologias de participação nos hospitais. A análise aqui realizada é essencialmente descritiva, visando a identificar e classificar os tipos de mecanismos existentes. A caracterização daí resultante é apresentada, levando em conta o histórico e as características fundamentais de cada organização hospitalar e os aspectos contextuais da política e do sistema de saúde.

Os hospitais são organizações que têm processos decisórios especialmente fechados à participação de atores externos ou subordinados na hierarquia de poderes que lhes é característica. Distinguem-se de outras instituições na medida em que as linhas de autoridade não se configuram apenas por meio da autoridade administrativa, mas principalmente pela existência de um forte poder técnico-profissional. São organizações com marcada dualidade de poder, polarizada entre médicos e administradores. Carapinheiro (1998), ao analisar a questão dos poderes no hospital, ressaltou que sua estruturação característica nas sociedades contemporâneas e seu funcionamento cotidiano são o resultado de uma ordem negociada entre os diversos atores, com preponderância dos médicos, cujo poder tem sido posto à prova crescentemente por administradores hospitalares.
\end{abstract}


Assim, usuários dos serviços hospitalares, outros profissionais e, principalmente, trabalhadores não profissionalizados ocupam as posições subordinadas ao poder médico e administrativo.

Mesmo considerando que médicos e administradores são os atores predominantes na hierarquia hospitalar e os principais responsáveis pelas decisões ali tomadas, os gestores do sistema de saúde vêm crescentemente procurando interferir nas organizações hospitalares, especialmente naquelas sob sua gestão direta. Eles participam ativamente na negociação que decide tanto sobre recursos financeiros destinados aos hospitais quanto sobre as relações destes com o sistema de saúde e, em última análise, sobre a relevância assistencial desses recursos. No caso específico dos hospitais estudados, o gestor federal - Ministério da Saúde - define inclusive quem ocupará seus principais cargos de chefia.

Examinam-se aqui mecanismos de participação em hospitais que visam a propiciar o envolvimento de atores sociais - profissionais e trabalhadores de saúde e entidades que representam os interesses de usuários de serviços hospitalares - que têm sido criados pela indução de gestores federais. Os hospitais analisados, que estão vinculados ao Ministério da Saúde, foram pesquisados pelo Projeto Fortalecimento da Gestão Hospitalar para o SUS (Côrtes \& Ferla, 2006). ${ }^{1}$ Uma das linhas de investigação do projeto focalizava a permeabilidade das organizações hospitalares à participação de diferentes atores, trabalhassem eles nos hospitais ou fossem externos a eles. As informações obtidas pelo projeto permitiram caracterizar as unidades hospitalares examinadas e obter indicações iniciais sobre a natureza dos mecanismos de participação que elas abrigavam.

A pesquisa também envolveu a observação direta e a realização de entrevistas semi-estruturadas, no período de março a maio de 2006, com informantes-chave das próprias unidades hospitalares. Os respondentes foram predominantemente dirigentes das unidades. Sabe-se que a perspectiva desses atores organizacionais pode apresentar um viés positivo sobre a eficácia ou abertura ao envolvimento de participantes dos mecanismos participativos analisados. As observações diretas e a análise documental procuraram, ao

\footnotetext{
${ }^{1}$ Tal projeto partiu da premissa de uma defasagem na capacidade das instituições hospitalares em responder adequadamente às demandas locorregionais no atual estágio de organização do sistema de saúde brasileiro (Brasil, 2004). Ele buscou analisar, em profundidade, os mecanismos e tecnologias desenvolvidos nas unidades hospitalares vinculadas ao Ministério da Saúde para subsidiar a cooperação técnica e financeira deste com as demais esferas de governo e com serviços e redes.
} 
menos em parte, compensar o problema. Mesmo assim, os resultados da pesquisa podem estar permeados por tal viés. Pesquisas futuras poderão verificar até que ponto isso comprometeu os resultados aqui apresentados.

A seguir, caracterizam-se os hospitais analisados e examina-se o contexto político que favoreceu que fossem criados, mantidos e expandidos mecanismos participativos nos hospitais. Depois descrevem-se os mecanismos participativos, propriamente ditos, tanto individuais como coletivos, identificados pela pesquisa.

\section{CARAC TERIZAÇÃO DOS HOSPITAIS: ORIGENS, PRINCIPAIS SERVIÇOS E NÚMERO DE LEITOS}

Os hospitais estudados pertenciam ao Ministério da Saúde. Eram os únicos no país, até março de 2005, que ainda estavam sob gestão da esfera federal de governo. ${ }^{2}$ Localizam-se nas cidades-centro das regiões metropolitanas de dois estados da federação: são eles o Grupo Hospitalar Conceição, em Porto Alegre (RS); o Instituto Nacional do Câncer, o Instituto Nacional de Traumato-Ortopedia, o Instituto Nacional de Cardiologia Laranjeiras, o Hospital Geral de Bonsucesso e o Hospital dos Servidores do Estado, na cidade do Rio de Janeiro (RJ). Trata-se de serviços de grande porte com unidades assistenciais extremamente especializadas. ${ }^{3}$ Mesmo no caso dos 'hospitais gerais', a construção de um perfil cada vez mais especializado mobiliza os atores internos. ${ }^{4}$

\footnotetext{
2 O estudo não incluiu os hospitais vinculados ao Ministério da Saúde por meio do decreto federal n. 5.392, de 10 de março de 2005. Essa escolha embasou-se no fato de que a requisição determinada por esse instrumento pretendia ser provisória e foi induzida por situação de crise na assistência hospitalar do Rio de Janeiro. Parte desses hospitais permaneceu vinculada ao Ministério da Saúde após o término da requisição. No entanto, considerando que apenas recentemente passaram à gestão federal, essas organizações hospitalares teriam caracteristicas muito diferentes das demais, não se apresentando como hospitais típicos do Ministério da Saúde.

${ }^{3}$ A especialização compõe uma das características constitutivas da racionalidade médica contemporânea (Luz, 2004). Essa característica do modelo de produção do conhecimento impacta os sistemas de cuidado, seja pela fragmentação dos atos assistenciais, seja pelo fortalecimento das hierarquias de poder entre as corporações (Carapinheiro, 1998). Além dos efeitos assistenciais e na dinâmica interna de poder, a especialização dos serviços hospitalares condiciona a interferência de atores externos na gestão dessas organizações, inclusive no que se refere à participação delas em redes de cuidado definidas pelo sistema de saúde (Cecilio \& Merhy, 2003).

${ }^{4}$ No periodo da pesquisa, a proposta de transferir o vinculo dos hospitais HGB e HSE do Ministério da Saúde para o estado ou para o municipio do Rio de Janeiro provocou a reação da direção, do corpo clinico e dos demais trabalhadores dessas unidades. Eles defendiam o perfil especializado dos hospitais, o que justificaria a manutenção do vinculo federal.
} 
O GHC é o único serviço ainda sob gerência do Ministério da Saúde em Porto Alegre, município que está habilitado na gestão plena do sistema municipal de saúde. Um aspecto relevante para a análise aqui empreendida é que há experiências marcantes de participação no município (Avritzer, 2002; Côrtes, 2002; Santos, 2002; Fedozzi, 1999). Além disso, a Região Metropolitana de Porto Alegre apresenta padrões altos de associativismo e interesse por política (IBGE, 1996; Baierle, 1992; Silva, 2001). Esses fatos podem se constituir em diferencial no contexto das unidades hospitalares estudadas, uma vez que tal fator, de acordo com a literatura, pode estar na origem de demandas crescentes de permeabilidade na gestão pública (Silva, 2006).

O Rio de Janeiro, como ex-capital do país, é caracterizado pela existência de vários serviços estatais de saúde - da União, do estado ou do município - e por um contexto político administrativo que apresenta forte presença da União, em decorrência de sua história. $\bigcirc$ processo de descentralização da saúde no estado, e em especial no município do Rio de Janeiro, passou por um retrocesso no período em que se desenvolveu a pesquisa, na medida em que o município perdeu a condição de gestão plena do sistema municipal de saúde ${ }^{5}$ em 2006 (Côrtes \& Ferla, 2006). Em que pese a responsabilidade legal das três esferas de governo e, portanto, a obrigação formal de garantir o regular funcionamento do sistema de saúde, quando consideradas as diretrizes constitucional e administrativas de gestão descentralizada do Sistema Único de Saúde (SUS), a inversão da transferência de poder aos municípios contraria, sem dúvida, a tendência atual das políticas de saúde no país.

A seguir, apresenta-se a história e a caracterização de cada um dos hospitais pesquisados. ${ }^{6}$

○ Grupo Hospitalar Conceição (GHC) está vinculado ao Ministério da Saúde desde 1975 e tem o status legal de uma sociedade anônima, na

\footnotetext{
${ }^{5}$ Ao perder a condição de gestor pleno do sistema de saúde, o municipio deixou de ser responsável pela gestão de todos os serviços de saúde financiados com recursos públicos em sua jurisdição territorial. Para mais esclarecimentos sobre as modalidades de gestão municipal, ver: NOB SUS 96 (Brasil, 1996), Noas SUS 01/02 (Brasil, 2002), Pacto pela Saúde (Brasil, 2005a) e Pacto de Gestão do SUS (Brasil, 2005b).

${ }^{6}$ Entre outras fontes, incluindo registros existentes nos próprios hospitais e relatórios do Ministério da Saúde, a caracterização histórica dos hospitais no Rio de Janeiro utilizou as revisões feitas por Parada (2001) e Machado (2001). Análises adicionais do processo de implantação do SUS no Rio de Janeiro foram publicadas em dois números com tema especifico da revista Physis, do Instituto de Medicina Social da Universidade do Estado do Rio de Janeiro (v. 11, n. 1, 2001).
} 
qual a União é o acionista majoritário. Localizado em Porto Alegre, capital do Rio Grande de Sul, é o único hospital próprio do Ministério da Saúde fora do estado do Rio de Janeiro. A constituição do GHC foi iniciada em 1956, com a construção do Hospital Cristo Redentor como empresa privada. Durante a década de 1960, o fundador do GHC expandiu a oferta de leitos no Hospital Cristo Redentor e construiu o Hospital Nossa Senhora da Conceição e o Hospital Criança Conceição. Em 1973, o Hospital Fêmina S. A. foi incorporado ao GHC. Devido à aguda crise financeira e assistencial do grupo, em 1975, um interventor foi designado pelo presidente da República para assumir a direção do grupo, desapropriando os quatro hospitais e iniciando o controle federal da instituição.

O Hospital Nossa Senhora da Conceição (HNSC), que é um hospital geral, possui 839 leitos e oferece todas as especialidades de um hospital geral em seu ambulatório, na emergência e na internação. Tem a maior emergência do Rio Grande do Sul, na qual são atendidas diariamente cerca de oitocentas pessoas. O Hospital Cristo Redentor (HCR), que tem como característica o atendimento ao trauma, principalmente de vítimas de acidentes e violências, dispõe de 282 leitos. O Hospital Criança Conceição (HCC), hospital geral pediátrico, possui 252 leitos. $\bigcirc$ Hospital Fêmina (HF), hospital materno-infantil, com emergência ginecológica, obstétrica e oncológica, tem 191 leitos. O GHC dispõe também do Serviço de Saúde Comunitária (SSC), formado por 12 postos de saúde instalados em bairros da Zona Norte de Porto Alegre.

O Instituto Nacional do Câncer (Inca) originou-se do Centro de Cancerologia, criado em 1938. Em 1941, o Centro vinculou-se ao Serviço Nacional de Câncer do Ministério da Saúde, quando passou a coordenar as ações da política nacional de controle de câncer. Transformado em instituto em 1944, atualmente o Inca é uma unidade integrante da Secretaria de Atenção à Saúde do Ministério da Saúde, responsável por desenvolver e coordenar ações integradas, de caráter multidisciplinar, para a prevenção e o controle do câncer no Brasil. Tais ações compreendem a assistência médico-hospitalar, prestada diretamente aos pacientes com câncer no âmbito do SUS. O instituto tem áreas estratégicas, como a prevenção e a detecção precoce, a formação de profissionais especializados, o desenvolvimento da pesquisa e a informação epidemiológica. Também é responsável pela formulação da política nacional de prevenção e controle do câncer no país. O Inca dispõe de quatro unidades, todas situadas na cidade do Rio de Janeiro: HCI: sede da Direção Geral e Centro de Trans- 
plante de Medula Óssea - 188 leitos; HCII: especializada em câncer ginecológico - 34 leitos; HCIII: especializada em câncer de mama - 52 leitos; e HCIV: unidade de cuidados paliativos.

O Instituto Nacional de Traumato-Ortopedia (Into) originou-se do Hospital Central de Acidentados, criado em 1943, com a finalidade de atender aos funcionários e segurados do Lloyd Brasileiro. Em 1973, então desativado, foi adquirido pelo Instituto Nacional de Previdência Social (INPS) para prestar atendimento em traumato-ortopedia, passando a denominar-se Hospital de Traumato-Ortopedia (HTO). Como tal, foi responsável pela introdução de técnicas inovadoras da especialidade, dando início a uma fase de ênfase ao aperfeiçoamento dos profissionais especializados e à abertura do hospital às ações comunitárias. Em 1991, foi estadualizado, o que na prática acarretou drásticas restrições orçamentárias. Após dois anos sob gestão estadual, voltou ao âmbito do Ministério da Saúde, assumindo a posição de referência nacional em traumato-ortopedia. Em 1994, já com a atual denominação, foi instituído, pelo Ministério da Saúde, como órgão normatizador de procedimentos em ortopedia no país, atuando então mais intensamente na formação de recursos humanos e na promoção de ações multiprofissionais. Passou a atender exclusivamente pacientes do SUS, destacando-se como um centro de excelência no tratamento de doenças e traumas ortopédicos, de média e alta complexidades. O Into localiza-se no centro da capital do Rio de Janeiro, possui 144 leitos, não atende emergência, nem procura espontânea. É um hospital para atendimento preferencialmente em alta complexidade e sempre com indicação de cirurgia.

O Instituto Nacional de Cardiologia Laranjeiras (INCL) originou-se do Hospital de Clínicas de Laranjeiras, fundado em 1972, como unidade vinculada ao INPS. Em 1973, passou a ser chamado Hospital de Cardiologia de Laranjeiras, ao mesmo tempo que se definia como hospital especializado. Em 1991, foi repassado à Secretaria Estadual de Saúde do Rio de Janeiro e, por decorrência de dificuldades de financiamento, devolvido ao governo federal em 1993. Em 2000, transformou-se em instituto, assumindo sua denominação atual. Com base no nivel de excelência em serviços de investigação diagnóstica e no tratamento das doenças cardiovasculares, o instituto tornouse um centro de referência do Ministério da Saúde para a realização de pesquisa, formulação de políticas de saúde e formação de pessoal. Em maio de 2001, passou a ser vinculado diretamente ao Ministério da Saúde. O INCL dispõe de 170 leitos e sua atividade principal é a assistência em cardiologia de 
alta complexidade para a população do município e do estado do Rio de Janeiro. Engloba ações de assistência, tais como prevenção, diagnóstico, tratamento clínico-cirúrgico das afecções cardiovasculares, bem como de reabilitação.

O Hospital Geral de Bonsucesso (HGB) originou-se do antigo Hospital General do Nascimento Vargas do Instituto de Aposentadoria e Pensão dos Empregados em Transporte e Cargas (Iapetec), criado em 1948. Em 1967, o HGB passou a fazer parte do INPS. A partir de 1974, o Instituto Nacional de Assistência Médica da Previdência Social (Inamps) assumiu a sua gerência. Em 1990, no hospital se iniciou uma experiência de co-gestão entre o Ministério da Saúde e a Secretaria Municipal de Saúde do Rio de Janeiro, mas em 1994 ele passou a vincular-se apenas à gestão federal. O HGB é um hospital geral, que dispõe de 470 leitos, serviços de emergência, maternidade de nível III, ${ }^{7}$ modalidades extra-hospitalares de assistência, com serviços terciários de referência para a Região Metropolitana do Rio de Janeiro e todo o estado.

O Hospital dos Servidores do Estado (HSE) foi criado em 1934, com a denominação de Hospital dos Funcionários Públicos. Em 1938, foi incorporado ao Instituto de Previdência e Assistência dos Servidores do Estado (Ipase) e adotou a denominação que mantém até os dias de hoje. No início da década de 1990, a gestão do HSE passou para a esfera estadual do sistema de saúde, retornando ao Ministério da Saúde em 1993. O HSE, localizado no centro da capital do Rio de Janeiro, é uma instituição de referência regional em especialidades clínicas e cirúrgicas com 515 leitos de internação. Desde a sua origem, desenvolveu também atividades de ensino e pesquisa. Foi o criador, no país, de um centro de estudos em hospital, organizado em torno de uma biblioteca e da edição de uma revista médica. Atualmente, desenvolve ensino de pós-graduação em regime de residência e estágio.

Esses hospitais têm como características comuns serem organizações de grande porte (GHC, HGB e HSE) e/ou especializadas em alguma área assistencial específica (Into, INCL e Inca). À exceção do GHC e do Inca, os demais pertenceram ao sistema previdenciário, sendo transferidos para o

\footnotetext{
${ }^{7}$ O Certificado de Acreditação com Excelência Nivel III indica a mais alta qualidade na prestação de serviços hospitalares, comprometimento com a segurança e a ética profissional. É concedido pela Organização Nacional de Acreditação e reconhecido pelo Ministério da Saúde, mediante avaliação do Instituto Qualisa de Gestão (IQG).
} 
sistema de saúde na década de 1990. Apesar de o Into, o INCL, o HGB e o HSE terem passado por experiências de descentralização da gestão para o estado ou município, retornaram à gestão e ao vínculo federal, e esse é outro aspecto comum entre eles. A manutenção da ligação com o Ministério da Saúde mobiliza internamente os atores dessas instituições, ou seja, há movimentos explícitos para a permanência desse vínculo.

Existem resistências à implantação de mecanismos de participação, mas elas concentram-se nas direções de organizações hospitalares credenciadas pelo SUS. ${ }^{8}$ Os dirigentes das organizações hospitalares em exame procuraram responder positivamente às políticas propostas pelo Ministério da Saúde, com o objetivo de estreitar seus laços com os gestores federais de saúde, e agir como organizações afinadas com as políticas federais. Desse modo, tornaram-se inovadores na institucionalização de mecanismos participativos em hospitais, afinando as características dessas organizações com aquelas já encontradas em outras unidades e esferas de gestão do sistema de saúde brasileiro que têm se destacado pela incorporação de novos atores ao processo decisório.

\section{Poútica de Saúde e Criação de Mecanismos PARTICIPATIVOSHOSPITALARES}

Em 2003, assumiu o governo federal uma coalizão política liderada pelo Partido dos Trabalhadores (PT). Desde então os gestores federais do SUS, com prerrogativas formais de regulação e de financiamento, procuram construir instrumentos de regulação na gestão das unidades hospitalares do Ministério da Saúde e aumentar sua capacidade de influir sobre as decisões internas. Na verdade, parte das iniciativas desencadeadas busca interferir na organização dos hospitais em geral, uma vez que a análise do ministério mostra problemas importantes nesse âmbito para a efetiva vinculação dessas instituições ao sistema de saúde e, em particular, às diretrizes que compõem as politicas federais para o setor saúde (Brasil, 2004). Uma dessas iniciativas, o Programa Nacional de Humanização da Assistên-

\footnotetext{
${ }^{8}$ Como foi o caso de resistência dos hospitais do Rio Grande do Sul, quando a Secretaria Estadual de Saúde e o Conselho Estadual de Saúde propuseram a formação de conselhos gestores nos hospitais como critério para o recebimento de recursos do Projeto Saúde Solidária (Ferla \& Jaeger, 2002; Ferla et al., 2002).
} 
cia Hospitalar (PNHAH), foi criada e iniciou sua implementação em 2000, portanto, ainda no período do governo de Fernando Henrique Cardoso. A partir de 2004, os novos gestores federais redefinem o PNHAH, ao implantar a Política Nacional de Humanização do SUS (HumanizaSUS), da Política Nacional de Gestão Estratégica e Participativa do SUS (ParticipaSUS) e da contratualização dos serviços hospitalares de ensino. ${ }^{9}$ Tais medidas buscavam reconfigurar o modo como se processava a gestão no sistema e, no que diz respeito ao objeto da análise aqui proposto, criaram e buscaram implementar mecanismos participativos de gestão em saúde.

A existência de fóruns de participação em saúde é condição necessária para que estados e municípios recebam recursos financeiros da esfera federal. Diferentes atores, articulados nesses fóruns, têm procurado induzir a oferta de serviços, inclusive hospitalares, a ser mais compatível com suas necessidades, e o sistema de saúde a responder de forma mais adequada aos seus interesses. Um dos objetivos das políticas governamentais, ao criarem mecanismos e instrumentos de participação, é que eles contribuam para dar 'voz'10 aos diferentes atores que participam em organizações hospitalares, favorecendo mudanças institucionais que viabilizem a implementação dos programas e políticas governamentais.

A ampliação dos espaços de participação nos hospitais poderia induzir à mudança e à constituição de novos modos de gestão e de atenção nesses serviços. A suposição é baseada em vários estudos sobre os fóruns participativos que "admitem que tais mecanismos podem colaborar para melhorar a governança, favorecer a implementação ou a mudança das políticas, tornando-as mais adequadas e aumentando a adesão das clientelas às propostas assim elaboradas" (Côrtes, 2006: 419-420).

\footnotetext{
${ }^{9}$ Os regulamentos técnicos do programa de reestruturação e contratualização dos hospitais filantrópicos e da contratualização entre os hospitais de ensino e gestores de saúde (Brasil, 2004) prevêem a adoção de mecanismos para democratização da gestão, apresentados como dispositivos para seu aperfeiçoamento e ampliação da transparência administrativa, e a ampliação dos mecanismos de controle social.

${ }^{10}$ A categorização de Hirschman sobre as possibilidades de se exercer influência nas organizações pode ser útil para analisar o envolvimento dos atores societais e estatais nos hospitais. Segundo esse autor, "existem duas maneiras de exercer influência: a 'saida', típico mecanismo de mercado através do qual o consumidor (ou empregado, ou apoiador de partido político) desiste de comprar ou de usar um determinado produto ou serviço, ou deixa a organização; e a 'voz', tipico mecanismo politico através do qual ele protesta, expressa oposição, preferências, exerce influência" (apud Côrtes, 2005: 23).
} 
Os gestores federais pretendem induzir mudanças em um contexto em que é recorrente a afirmação de uma crise dos serviços hospitalares no país, que se torna visivel no cotidiano, nas dificuldades de atendimentos, nas superlotações dos serviços, bem como na insuficiência de recursos financeiros (Brasil, 2004). A consolidação de processos participativos em hospitais poderia colaborar para tais mudanças, ao enfraquecer a resistência do poder médico e administrativo, pondo em questão sua legitimidade em decidir isoladamente sobre todos os assuntos técnicos e administrativos nos hospitais, como é tradicional nessas organizações.

Processos de participação teriam a capacidade de induzir alterações nos mecanismos gerenciais, de planejamento e controle. Freqüentemente, esses mecanismos constituem-se em instrumentos burocratizados, verticalizados e voltados para a organização das práticas, da divisão do trabalho e da definição de prioridades organizacionais. As alterações também afetariam as modelagens tecnoassistenciais, tanto na perspectiva da inserção do hospital na rede de cuidados, e no direcionamento de suas ações para as necessidades em saúde, quanto na perspectiva da mudança nas práticas de atenção no interior do hospital, para que elas estejam centradas nas pessoas que necessitam do cuidado (Brasil, 2004). Daí a importância de se identificar se os hospitais têm instrumentos de participação instituídos. Por meio deles poderia haver o envolvimento explícito no processo decisório das organizações, não apenas de médicos, administradores, gestores do sistema, mas também de atores sociais, tais como representantes de entidades de profissionais e trabalhadores de saúde, de associações comunitárias, e de usuários individuais de serviços hospitalares. Na próxima seção, são descritos os principais mecanismos de participação identificados nos hospitais examinados.

\section{Os Mecanismos de ParticipaÇão nos HospitaIS do MINISTÉRIO dA SAÚDE}

A pesquisa que embasou este estudo buscou identificar os mecanismos de participação existentes nos hospitais em foco, descrevê-los e caracterizar as formas de participação encontradas. Os principais mecanismos identificados foram: conselhos gestores, ouvidorias, fóruns que envolvem os trabalhadores de saúde nos processos decisórios de gestão, nos quais gestores do sistema, representantes de grupos de interesse e usuários individuais 
buscam expressar suas demandas ou propostas. ${ }^{11}$ Era necessário, ainda, identificar e classificar os participantes nos fóruns e mecanismos examinados. Os dirigentes dos hospitais analisados foram considerados como atores estatais de tipo 'governamental', juntamente com os gestores do sistema, porque as organizações estudadas eram serviços vinculados diretamente ao Ministério da Saúde; portanto, os diretores - tanto de nível geral como intermediário - eram escolhidos pelos gestores federais de saúde. Os demais atores, classificados como societais 'sociais', eram representantes de profissionais e trabalhadores de saúde dos hospitais; de associações de moradores, movimentos sociais e organizações não governamentais (ONGs); de entidades de portadores de patologias. Os representantes podem ser designados pela direção dos hospitais, escolhidos pelas categorias de profissionais ou trabalhadores, ou indicados por entidades ou outras instâncias de participação, como os conselhos municipais de saúde, por exemplo. Foram classificados também como 'sociais' os participantes individuais em serviços de ouvidoria ou pesquisas de satisfação, fossem eles profissionais ou trabalhadores de saúde dos próprios hospitais, fossem usuários dos serviços oferecidos nas unidades hospitalares examinadas. Havia ainda atores societais 'de mercado’ representando prestadores de serviços de saúde. Estes foram os participantes com menor expressão nos fóruns ou mecanismos de participação analisados.

$\mathrm{Na}$ busca de sistematização dos mecanismos de participação existentes nesses hospitais, constatou-se que os mais freqüentes são os fóruns colegiados, nos quais é possivel identificar a presença de diferentes atores agindo por meio de um ou mais representantes. No entanto, há mecanismos que auscultam demandas, queixas ou manifestações individuais de profissionais e trabalhadores de saúde e de usuários dos serviços dos hospitais.

Assim, os mecanismos de participação foram classificados conforme tipologia que considera: a 'natureza dos mecanismos de participação', individual e coletiva; a 'natureza dos atores envolvidos nos fóruns', os atores governamentais e atores sociais; a 'estabilidade institucional', pontual, episódica, institucionalizada, freqüente; a 'natureza do objeto da participação', gestão em geral (inclusive investimentos), gestão de processos admi-

${ }^{11}$ Em hospitais do Rio Grande do Sul, observou-se a existência de experiências como Conselho Gestor do Hospital Casa de Saúde, em Santa Maria (Peretti et al., 2002), Conselho Gestor do Hospital de Pronto Socorro, em Porto Alegre, e Conselho Gestor do Grupo Hospitalar Conceição, em Porto Alegre. 
nistrativo-operacionais, gestão de processos comunicativo-informacionais e gestão do ensino e da pesquisa; ${ }^{12}$ a 'forma da participação', aberta, ampliada, hierarquizada, por meio de representantes; o 'âmbito da participação', alta gerência, gerência estratégica (de investimento e de cuidado), gerência intermediária, gestão de insumos, equipes e serviços, processos de trabalho; e o 'grau de institucionalização', informal e formal. $\bigcirc$ Quadro 1 apresenta uma síntese dos mecanismos participativos encontrados nos hospitais examinados, de acordo com as classificações mencionadas.

Quadro 1 - Mecanismos de participação em hospitais do Ministério da Saúde - 2005

\begin{tabular}{|c|c|c|c|c|c|}
\hline \multicolumn{6}{|c|}{ Atores externos } \\
\hline Abrangência & \multicolumn{3}{|c|}{ Coletiva } & \multicolumn{2}{|c|}{ Individual } \\
\hline Mecanismo & \multicolumn{2}{|c|}{ Fóruns, conselhos, comissões no hospital } & $\begin{array}{l}\text { Orçamento } \\
\text { participativo }\end{array}$ & Ouvidoria & $\begin{array}{l}\text { Pesquisa } \\
\text { satisfação de } \\
\text { usuários }\end{array}$ \\
\hline $\mathrm{GHC}$ & \multicolumn{2}{|l|}{ Sim } & $\begin{array}{l}\text { Sim (atores } \\
\text { externos e } \\
\text { internos) }\end{array}$ & Sim & Sim \\
\hline HGB & \multicolumn{2}{|l|}{ Sim } & Não & Sim & Não \\
\hline HSE & \multicolumn{2}{|l|}{ Sim } & Não & Sim & Sim \\
\hline Inca & \multicolumn{2}{|l|}{ Sim } & Não & Sim & Sim \\
\hline INCL & \multicolumn{2}{|l|}{ Não } & Não & Sim & Sim \\
\hline Into & \multicolumn{2}{|l|}{$\operatorname{Sim}$} & Não & Sim & Sim \\
\hline \multicolumn{6}{|c|}{ Atores internos } \\
\hline Abrangência & \multicolumn{3}{|c|}{ Coletiva } & \multicolumn{2}{|c|}{ Individual } \\
\hline Mecanismo & $\begin{array}{l}\text { Colegiados de gestão, } \\
\text { comissões, grupos de } \\
\text { trabalho, planejamen to }\end{array}$ & $\begin{array}{l}\text { Mesa de } \\
\text { negociação com } \\
\text { profissionais e } \\
\text { trabalhadores }\end{array}$ & $\begin{array}{l}\text { Orçamento } \\
\text { participativo }\end{array}$ & $\begin{array}{l}\text { Ouvidoria de } \\
\text { profissionais e } \\
\text { trabalhadores }\end{array}$ & $\begin{array}{c}\text { Pesquisa de } \\
\text { satisfação de } \\
\text { profissionais e } \\
\text { trabalhadores }\end{array}$ \\
\hline GHC & Sim & Não & $\begin{array}{l}\text { Sim (atores } \\
\text { externos e } \\
\text { internos) } \\
\end{array}$ & Não & $\begin{array}{l}\text { Realizou em } \\
1998\end{array}$ \\
\hline HGB & Sim & Não & Não & Sim & Não \\
\hline HSE & Sim & Não & Não & Não & Não \\
\hline Inca & Sim & Não & Não & Sim & $\begin{array}{l}\text { Realiza desde } \\
1998\end{array}$ \\
\hline INCL & Sim & Não & Não & Não & Não \\
\hline Into & Sim & Não & Não & Sim & Não \\
\hline
\end{tabular}

Fonte: Adaptado de Côrtes e Ferla (2006).

12 Foram ainda identificados como objetos de participação: a gestão de processos de cuidado (ampliação da clinica), bem como o compartilhamento da responsabilidade assistencial e de acesso. Neste estudo, no entanto, são analisados unicamente os mecanismos de participação na gestão institucional dos hospitais, reservando-se para análise em trabalhos futuros os resultados relativos à participação no cuidado. 


\section{MECANISMOS DE PARTICIPAÇÃO INDIVIDUAL}

Os mecanismos de participação individual encontrados nos hospitais foram as 'ouvidorias' e as 'pesquisas de satisfação', ou seja, mecanismos de escuta e consulta dos atores sociais: profissionais e trabalhadores dos hospitais e os usuários de seus serviços. As ouvidorias estavam presentes em todas as unidades hospitalares examinadas, como um dispositivo de participação aberto, institucionalizado e formalizado. Elas se distinguiam no que diz respeito à natureza dos atores envolvidos. Enquanto no Inca, no Into e no HGB a ouvidoria era um espaço de expressão individual de profissionais e trabalhadores e de usuários, nos demais hospitais era destinada unicamente a receber queixas de usuários individuais.

O lugar organizacional da ouvidoria também variou conforme os hospitais. No Inca há referência a uma ação mais articulada com a gestão, uma vez que o ouvidor fazia parte do Conselho Deliberativo do hospital. Desse modo, por meio dele, as queixas apresentadas à ouvidoria podiam, mais facilmente, influir sobre aspectos gerenciais ou de cuidado. Nos outros hospitais, os responsáveis pelas respostas às queixas que chegavam à ouvidoria pertenciam às gerências intermediárias e às equipes e aos serviços dessas instituições hospitalares. No HSE, no HNCL, no Into e no $\mathrm{HGB}$, as queixas e demandas eram respondidas de modo pontual. As questões referiam-se à gestão de processos comunicativoinformacionais, na medida em que as ouvidorias limitavam-se a receber e devolver informações àqueles que as acionavam. Não havia definição de procedimentos que garantissem que essa participação resultasse necessariamente em mudanças na organização ou que interferisse na gestão geral do hospital.

No GHC, além do processo de queixa-resposta, foram verificados procedimentos de reavaliação provocados por reclamações que podiam gerar mudanças em processos de trabalho e organização de serviços. Portanto, há indicações de que as queixas de usuários individuais encaminhadas à ouvidoria interferiam, ainda que pontualmente, em processos de gestão administrativo-operacionais e de cuidado.

Outro mecanismo de participação individual encontrado foi a 'pesquisa de satisfação de usuários e trabalhadores'. A regularidade com que as pesquisas se realizavam e o seu nível de institucionalização nos hospitais 
variavam conforme os respondentes a que elas se dirigiam. Elas podiam buscar a coleta de informações de profissionais e trabalhadores de saúde ou de usuários dos serviços hospitalares.

As pesquisas de satisfação de profissionais e trabalhadores realizaram-se de forma episódica nos hospitais examinados. Não há registros de institucionalização em nenhum deles. Eram direcionadas, principalmente, para a qualificação dos processos administrativo-operacionais de gestão, relacionados à melhoria das condições de trabalho nos hospitais. Já as pesquisas de satisfação de usuários eram institucionalizadas e feitas regularmente em quase todos os hospitais, à exceção do HGB. Por meio delas, eram aplicados questionários respondidos por parcelas de usuários internados ou no momento da alta. No Inca, no GHC e no INCL, essas pesquisas subsidiavam processos de gestão administrativo-operacionais e de cuidado. Os resultados eram disponibilizados aos gerentes das áreas para serem utilizados no controle e na avaliação dos serviços. Nesses hospitais as pesquisas incidiam, portanto, na gestão intermediária, de insumos e de equipes e serviços. O HSE e o Into não informaram como os resultados das pesquisas eram empregados.

\section{MECANISMOS DE PARTICIPAÇÃO COLETIVA}

Os mecanismos de participação coletiva encontrados foram os seguintes: 'colegiados de gestão', 'processos de planejamento', 'plano anual de investimento participativo', 'comissões temáticas' e 'conselhos'.

Em todos os hospitais verificou-se a existência de algum 'colegiado de gestão', no âmbito da alta gerência, que reunia o corpo diretivo da organização. Todos os colegiados de gestão tratavam do planejamento e da gestão geral dos hospitais e não incorporavam outros atores além daqueles internos à instituição, majoritariamente pertencentes ao grupo diretivo. Os colegiados possibilitavam a expressão da opinião dos atores envolvidos e a construção de decisões, em geral consensuais.

No HGB e no HSE, no momento da pesquisa não havia colegiados de gestão ativos. Isso ocorria porque nos dois hospitais estava havendo transição entre um corpo de dirigentes e outro, que havia assumido recentemente. Nos demais hospitais esses fóruns estavam institucionalizados e funcionavam com reuniões periódicas, semanais ou mensais, sendo compostos por pessoas que ocupavam cargos de chefia. 
No GHC, no Inca, no INCL e no Into existiam ainda outros colegiados, também institucionalizados. Nesses fóruns, decidia-se sobre processos administrativo-operacionais, de ensino e pesquisa e de cuidado. Eles se localizavam no âmbito da gerência intermediária, da gestão de insumos e de equipes e serviços.

Foi ainda observada a existência de 'processos de planejamento' em todos os hospitais, os quais envolviam debates e decisões grupais, não restritos apenas ao corpo diretivo das organizações. No Inca, no GHC, no INCL e no Into, o planejamento e o acompanhamento da implementação do planejado eram processos formalizados e permanentes. No HSE e no HGB, os processos de planejamento realizavam-se de forma episódica e não havia acompanhamento da implementação. Nos dois hospitais, observouse ainda que diretrizes estabelecidas em gestões anteriores não foram adotadas pelas equipes diretivas posteriores.

As informações obtidas mostram que os processos de planejamento incorporavam a participação direta de profissionais e trabalhadores de saúde dos próprios hospitais no HSE, no HGB, no INCL e no Inca. Apenas no INCL, no entanto, o processo era organizado em todas as unidades assistenciais e incluía as gerências de equipes e serviços. Havia participação direta de profissionais e trabalhadores do hospital, e os temas abordados se referiam aos processos de trabalho de cada área. As unidades definiam metas a serem atingidas em um período definido.

A participação formalizada e explícita de atores sociais no processo de planejamento foi verificada apenas no GHC. Os participantes, que não integravam o corpo diretivo da organização, eram representantes de profissionais e trabalhadores do próprio hospital, eleitos pelos seus pares, e representantes do Conselho Municipal de Saúde de Porto Alegre, dos três conselhos distritais em que havia serviços do grupo hospitalar e do próprio Conselho Gestor do hospital, sendo os últimos oriundos de entidades sociais. O processo de planejamento concentrava-se nas reuniões de um fórum anual, institucionalizado, o qual definia as prioridades de investimentos da organização para o ano seguinte, que compunham a base a partir da qual era elaborado o 'plano anual de investimento participativo'. Dessa forma, o Plano de Investimento do GHC era um mecanismo formalizado de participação coletiva que propiciava o envolvimento de atores sociais no planejamento do hospital. 
Outro mecanismo coletivo de participação observado em todos os hospitais examinados foram as 'comissões temáticas'. Verificou-se a existência de comissões permanentes de infecção hospitalar, de revisão de prontuário, de revisão de óbitos e transfusional, sem as quais os hospitais não poderiam funcionar, e ainda outras, de ética médica, de padronização de medicamentos, de materiais e procedimentos, de residência e de ética na pesquisa. Elas eram compostas majoritariamente por médicos, mas havia a presença, mesmo que minoritária, de outros profissionais, em especial da área de enfermagem e de farmácia. Havia ainda, em todas as unidades hospitalares, comissões de humanização, criadas por indução do Programa Nacional de Humanização da Assistência Hospitalar do Ministério da Saúde, nas quais a proporção de trabalhadores não profissionalizados e de outros profissionais era relativamente maior.

As comissões, no entanto, parecem desempenhar papéis diferenciados em alguns dos hospitais pesquisados. No caso do Into, a constituição dessas instâncias parece ser uma estratégia para a gestão de processos de trabalhos e para o debate de questões organizacionais críticas. No Into, mais do que nas outras unidades hospitalares em foco, as comissões propiciavam o envolvimento ampliado de trabalhadores nos processos de decisão organizacional. No caso do GHC, comissões eram formadas visando a promover o debate sobre questões relacionadas a padrões socialmente diferenciados de acesso a bens e serviços sociais e, particularmente, à influência de desigualdades sociais no tipo de atendimento oferecido pelo hospital. As comissões de políticas afirmativas, de igualdade racial, de acessibilidade e de mobilidade foram formadas com esses objetivos. Eram integradas por diferentes profissionais de saúde do hospital e por representantes de ONGs e associações que atuavam sobre a temática específica tratada na comissão.

O objetivo das comissões era aprofundar as discussões sobre tais temas, e o envolvimento dos participantes tinha um caráter prioritariamente consultivo. Cabia ao corpo diretivo dos hospitais decidir sobre a acolhida dos pareceres e sugestões que essas comissões produziam. Elas tinham como objeto de discussão a gestão dos processos administrativo-operacionais, a gestão de ensino e de pesquisa, a gestão de processos de cuidado. Situavamse nos âmbitos de gerência intermediária, de insumos, de equipes e serviços e de processos de trabalho.

Também havia 'conselhos' em todos os hospitais analisados, em geral situados no âmbito da alta gerência, institucionalizados, que tratavam da 
gestão geral do hospital. O Inca contava com dois conselhos. Ambos tinham responsabilidades relativas ao estabelecimento de diretrizes da política nacional de controle do câncer no país: o Conselho Consultivo do Inca (Consinca) e o Conselho de Bioética (Conbio). A composição do Consinca incluía representantes de entidades nacionais de pós-graduação em saúde; de prestadores de serviços de saúde; de sociedades científicas; gestores federal, estaduais e municipais de saúde; do fórum nacional de portadores de patologias - os últimos indicados pelo Conselho Nacional de Saúde. $\mathrm{O}$ objeto de discussão do Consinca era a política nacional do câncer e não assuntos internos ao hospital, como nos conselhos dos demais hospitais. Daí a variedade de atores lá encontrada, em contraste com aquela verificada nos demais fóruns e mecanismos de participação aqui analisados.

No GHC foi registrada a existência de três conselhos. O Conselho de Administração, instituído em 1975, desde a sua criação era composto por representantes governamentais e por um representante de entidade social, escolhido pela direção do hospital. Como resultado da política nacional de gestão participativa no SUS, desde 2003, essa composição se alterou. Passaram a integrar o Conselho representantes governamentais - do Ministério da Saúde e do Planejamento, das secretarias estadual e municipal (Porto Alegre) de Saúde, da direção do hospital; e representantes sociais - um membro eleito por profissionais e trabalhadores do hospital e outro indicado pelo Conselho Estadual de Saúde, o qual, no período analisado, era um profissional de saúde. Desde a década de 1990, também havia no GHC um Conselho Intercomunitário, composto por lideranças de associações de moradores e de profissionais e trabalhadores do Serviço de Saúde Comunitária do hospital, que debatia assuntos relacionados às unidades básicas de saúde do Serviço. Em 2004, formou-se o Conselho Gestor do GHC, fruto do mesmo processo de indução promovido pelos gestores do Ministério da Saúde. Fórum vinculado ao Conselho Municipal de Saúde de Porto Alegre, tinha como principal objeto de debates os serviços oferecidos pelo hospital. Metade de seus integrantes era indicada pelo Conselho Municipal de Saúde; a outra metade era composta por representantes de entidades de profissionais e trabalhadores de saúde, da gestão estadual e municipal de saúde e da direção do hospital.

Também sob influência das propostas de gestão participativa do Ministério da Saúde, a partir de 2005 foram instituídos conselhos de gestão participativa no HSE, no HGB, no Into e no Inca. A sua composição era 
tripartite, sendo um terço formado por representantes do corpo dirigente dos hospitais; outro terço, por representantes eleitos pelos profissionais e trabalhadores dos hospitais; e um terço por representantes dos conselhos locais de saúde das áreas de abrangência dos hospitais.

Foi possivel, assim, observar que os mecanismos de participação individual mais freqüentemente institucionalizados nos hospitais atingiam principalmente os usuários dos serviços. Percebeu-se que a utilização das informações geradas a partir dessa participação nos processos decisórios das organizações era pontual, e não atingia a gestão em geral do hospital. Havia mecanismos de participação coletivos em todos os hospitais que reuniam atores governamentais e sociais. Os colegiados de gestão e processos de planejamento aglutinavam principalmente o grupo diretivo dos hospitais. No entanto, observaram-se experiências em que atores sociais internos e externos ao hospital estavam inseridos no processo de planejamento. As comissões, via de regra, reuniam atores governamentais e sociais internos do hospital, mais especificamente profissionais de saúde, para discutir temáticas específicas e técnicas. Quando as temáticas em debate envolviam questões relacionadas à inclusão social, atores externos às organizações hospitalares eram incorporados às discussões.

No momento da pesquisa, os conselhos estavam presentes em todos os hospitais, com exceção do INCL. A composição deles era variável. No entanto, incluía atores governamentais e sociais, que podiam ser representantes tanto dos profissionais e trabalhadores do próprio hospital quanto de grupos de interesses externos a ele. $\bigcirc$ que chama a atenção sobre esses fóruns é que, com a exceção dos conselhos do Inca e do conselho de administração inicial do GHC, os demais foram instituídos entre 2003 e 2005. Ou seja, a maioria deles foi criada quando assumiram no Ministério da Saúde dirigentes identificados com a coalizão política liderada pelo Partido dos Trabalhadores, no governo do país desde 2003. Mecanismos participativos criados por indução das políticas federais, como a maioria dos conselhos identificados nos hospitais e o processo de planejamento participativo do GHC, não tinham o mesmo nível de institucionalização que os demais. Portanto, não é possivel afirmar se eles permanecerão funcionando em períodos posteriores de governo. 


\section{CONSIDERAÇÕES FINAIS}

Conforme se pôde verificar, as politicas federais atualmente vigentes têm reflexos na organização e no funcionamento dos hospitais estudados, vinculados ao Ministério da Saúde. Organizações hospitalares são consideradas instituições fechadas, com a dinâmica politica interna normalmente definida na interação de médicos e administradores. $\mathrm{O}$ desenho da investigação não permitiu dimensionar os efeitos organizacionais da participação nos hospitais examinados. Mesmo assim, a busca da identificação de mecanismos de participação partiu do pressuposto de que sua existência introduziria, no processo decisório dessas organizações, visões de outros atores sobre como os serviços hospitalares eram oferecidos, o que é um fato relevante por si só. Assim, mecanismos preexistentes e criados por uma politica de indução, mesmo que não substituam as formas tradicionais de decisão institucionalizadas, trazem dentro da organização visões e idéias sobre o sistema de saúde e sobre a própria instituição hospitalar que forçam os dirigentes hospitalares a, no mínimo, reconhecer sua existência durante os processos decisórios.

Verificou-se que já existiam - e também foram criados nos últimos anos - mecanismos participativos cujos integrantes preferenciais eram atores externos à organização hospitalar. Têm destaque o envolvimento individual de usuários dos serviços oferecidos pelo hospital e a participação, em fóruns colegiados, de atores sociais por meio de representantes de entidades sociais designados por outros fóruns participativos, como os conselhos nacional, estaduais, municipais e distritais de saúde. Menos freqüentes eram os mecanismos de participação abertos ao envolvimento de atores internos dos hospitais, ou seja, aos profissionais e trabalhadores de saúde das próprias organizações hospitalares. Constata-se, portanto, que as direções dos hospitais em foco pareciam estar mais abertas a consultar as opiniões de atores externos às organizações, em moldes similares aos mecanismos participativos já existentes no sistema de Saúde, tais como os conselhos analisados nos capitulos anteriores. As direções se mostraram mais resistentes a aceitar a incorporação de instrumentos de 'gestão participativa' que permitissem a expressão pública, no ambiente organizacional dos hospitais, das visões dos profissionais e trabalhadores de saúde das próprias organizações. Isso não quer dizer que os profissionais de saúde não influíam nos processos decisórios. Ao contrário, pode-se supor que especialmente os médicos conti- 
nuem influindo sobre as decisões de gestão - de forma explícita, ao ocupar cargos diretivos, e por meio de processos de decisão institucionalizados que são ocultos ou baseados na autoridade conferida ao saber técnico.

Os hospitais tenderam a responder positivamente às propostas dos gestores federais que estimulavam a criação dos fóruns e mecanismos colegiados e também de instrumentos de participação individual. Pode-se indagar, no entanto, em que medida mecanismos criados nos últimos anos, frutos da indução da gestão federal, permanecerão existindo após mudanças no governo federal e, portanto, no quadro dirigente dos hospitais.

Cabe destacar que a maior diversidade de mecanismos de participação coletiva foi encontrada no GHC. É possível supor que tal fato esteja associado à tradição de participação e de associativismo verificada na cidade de Porto Alegre. O ambiente político-institucional e o nível de organização da sociedade local poderiam ser uma explicação para o diferencial em relação às demais organizações hospitalares estudadas.

Assim, foi possivel verificar que, especialmente a partir de 2004, houve a ampliação dos mecanismos de participação individuais e coletivos nos hospitais e que estes passaram a consultar atores sociais internos e, principalmente, externos às organizações hospitalares em foco. A inclusão das visões desses atores nos processos decisórios das organizações pode significar que seus dirigentes, em alguma medida, passaram a levar em conta outros interesses que não o de médicos e de administradores hospitalares em suas decisões. A diversidade de situações encontradas, seja na composição dos fóruns e mecanismos, seja em seus níveis de institucionalização e âmbitos de influência, permitiu criar uma tipologia para a classificação desses dispositivos.

Espera-se que este estudo sirva de inspiração para pesquisas futuras, com objetivos analíticos mais complexos. A descrição dos tipos de mecanismos aqui empreendida é apenas a sistematização de uma investigação pioneira, mas tem como principal mérito inserir as organizações hospitalares no âmbito dos objetos empíricos que podem ser focalizados ao tratar do tema da participação em saúde. 


\section{REFERÊNCIAS}

AVRITZER, L. Modelos de deliberação democrática: uma análise do orçamento participativo no Brasil. In: SANTOS, B. S. (Org.) Democratizar a Democracia: os caminhos da democracia participativa. Rio de Janeiro: Civilização Brasileira, 2002.

BAIERLE, S. G. Um Novo Princípio Ético-Político: prática social e sujeito nos movimentos populares urbanos em Porto Alegre nos anos 80, 1992. Dissertação de Mestrado, Campinas: Universidade Estadual de Campinas.

BRASIL. Ministério da Saúde. Norma Operacional Básica do Sistema Único de Saúde (NOB-SUS) n. 01/96, de 6 de novembro de 1996.

BRASIL. Ministério da Saúde. Norma Operacional da Assistência à Saúde do Sistema Único de Saúde (Noas-SUS) n. 01/02, de 27 de fevereiro de 2002.

BRASIL. Ministério da Saúde. Reforma do Sistema da Atenção Hospitalar Brasileira. Brasília: Ministério da Saúde, 2004.

BRASIL. Ministério da Saúde. Secretaria Executiva. Subsecretaria de Planejamento e Orçamento. Plano Nacional de Saúde: um pacto pela saúde no Brasil - sintese. Ministério da Saúde, 2005a.

BRASIL. Ministério da Saúde. Secretaria Executiva. Departamento de Apoio à Descentralização. Pacto de Gestão: garantindo saúde para todos. Brasília: Ministério da Saúde, 2005b.

CARAPINHEIRO, G. Saberes e Poderes no Hospital: uma sociologia dos serviços hospitalares. 3. ed. Porto: Afrontamento, 1998.

CECÍLIO, L. C. O. \& MERHY, E. E. A integralidade do cuidado como eixo da gestão hospitalar. In: PINHEIRO, R. \& MATTOS, R. A. (Orgs.) Construção da Integralidade: cotidiano, saberes e práticas em saúde. Rio de Janeiro: Instituto de Medicina Social da Universidade do Estado do Rio de Janeiro, Abrasco, 2003.

CÔRTES, S. M. V. Construindo a possibilidade de participação dos usuários: conselhos e conferências no Sistema Único de Saúde. Sociologias, 7: 18-48, jan.-jun. 2002.

CÔRTES, S. M. V. Fóruns participativos e governança: uma sistematização das contribuições da literatura. In: LUBAMBO, C.; COÊLHO, D. B. \& MELO, M. A. (Orgs.) Desenho Institucional e Participação Política: experiências no Brasil contemporâneo. Petrópolis: Vozes, 2005.

CÔRTES, S. M. V. Céticos e esperançosos: perspectivas da literatura sobre participação e governança na área de saúde. In: PINHEIRO, R. \& MATOS, R. A. (Orgs.) Gestão em Redes: práticas de avaliação, formação e participação na saúde. Rio de Janeiro: Cepesp, 2006.

CÔRTES, S. M. V. \& FERLA, A. A. (Orgs.) Fortalecimento da gestão hospitalar para oSUS: desenvolvendo um sistema de acompanhamento e monitoramento dos hospitais próprios do Ministério da Saúde a partir de uma modelagem centrada nas pessoas sob cuidado e na diretriz de participação da população. Relatório de Pesquisa. Porto Alegre, 2006. 
FEDOZZI, L. Orçamento Participativo: reflexões sobre a experiência de Porto Alegre. 2. ed. Porto Alegre, Rio de Janeiro: Tomo Editorial, Observatório de Políticas Urbanas e Gestão Municipal, 1999.

FERLA, A. A. \& JAEGER, M. L. Controle social como processo: a participação da população na saúde e o orçamento participativo do estado do Rio Grande do Sul. In: FERLA, A. A. \& FAGUNDES, S. M. S. (Orgs.) Tempo de Inovações: a experiência da gestão na saúde do Rio Grande do Sul. Porto Alegre: Editora da Casa, Escola de Saúde Pública, 2002.

FERLA, A. A. et al. Regionalização da atenção à saúde na experiência de gestão estadual do SUS no Rio Grande do Sul. In: FERLA, A. A. \& FAGUNDES, S. M. S. (Orgs.) O Fazer em Saúde Coletiva: inovações da atenção à saúde no Rio Grande do Sul. Porto Alegre: Editora da Casa, Escola de Saúde Pública, 2002.

INSTITUTO BRASILEIRO DE GEOGRAFIA E ESTATÍSTICA (IBGE), 1996. Disponivel em: <www.ibge.gov.br/home/estatistica/populacao/condicaodevida/ indicadoresminimos/suppme/analiseresultados1.shtm>. Acesso em: 16 out. 2006.

LUZ, M. T. Natural, Racional, Social: razão médica e racionalidade científica moderna. 2. ed. rev. São Paulo: Hucitec, 2004.

MACHADO, C. V. Novos modelos de gerência nos hospitais públicos: experiências recentes. Physis - Revista de Saúde Coletiva, 11(1): 106-198, 2001.

PARADA, R. A construção do Sistema Estadual de Saúde: antecedentes e formas de inserção. Physis - Revista de Saúde Coletiva, 11(1): 19-104, 2001.

PERETTI, H. S. et al. Uma alternativa de saúde mergulhada na história: gestão pública solidária e controle social na viabilização da Casa de Saúde da Coopfer. In: FERLA, A. A. \& FAGUNDES, S. M. S. (Orgs.) O Fazer em Saúde Coletiva: inovações da atenção à saúde no Rio Grande do Sul. Porto Alegre: Editora da Casa, Escola de Saúde Pública, 2002.

SANTOS, B. S. Orçamento participativo em Porto Alegre: para uma democracia redistributiva. In: SANTOS, B. S. (Org.) Democratizar a Democracia: os caminhos da democracia participativa. Rio de Janeiro: Civilização Brasileira, 2002.

SILVA, M. K. A construção da 'participação popular': análise comparativa de processos de participação social na discussão pública do orçamento em municípios da Região Metropolitana de Porto Alegre/RS, 2001. Tese de Doutorado, Porto Alegre: Programa de Pós-Graduação em Sociologia, Instituto de Filosofia e Ciências Humanas, Universidade Federal do Rio Grande do Sul.

SILVA, M. K. Sociedade civil e construção democrática: do maniqueísmo essencialista à abordagem relacional. Sociologias, 16: 156-179, jul.-dez. 2006. 


\section{SINTESE DO DEBATE SOBRE
DINÂMICAS 6. UMA SIN ANISMOS E SISTEMA PARTIPATTVASUUDE}

Soraya Vargas Côrtes

Os estudos aqui reunidos procuraram introduzir perspectivas de análise inovadoras para o debate sobre participação na área da saúde. A primeira delas foi a recusa a falsos dilemas, sobre "se os conselhos de saúde são deliberativos" ou "se as relações entre os atores no interior desses fóruns são igualitárias". Guiados por tais questionamentos chegar-se-ia à constatação do óbvio, de que os conselhos de saúde são deliberativos apenas no sentido em que discutem exaustivamente as questões que estão na agenda setorial; e também de que as relações de poder em seu interior não são igualitárias. Em vez disso, as lentes de análise utilizadas nas pesquisas buscaram compreender como participavam atores societais e estatais e qual o papel dos conselhos na arena decisória setorial.

A segunda perspectiva refere-se ao fato de as investigações não se limitarem a realizar estudos de casos, tão comuns quando se trata da temática. Embora o Conselho Nacional de Saúde (CNS) e o Conselho Estadual de Saúde do Rio Grande do Sul sejam 'casos', o fórum federal é único. Apenas o Conselho gaúcho se enquadraria plenamente na acepção de um 'caso', extraído de um universo de 27 fóruns similares. No estudo dos conselhos municipais de saúde da Região Metropolitana de Porto Alegre (RMPA), o universo considerado é formado por todos os fóruns da região. Os resultados obtidos são generalizáveis apenas para as cidades da RMPA. Entretanto, 
pode-se supor que, em regiões metropolitanas com características semelhantes às de Porto Alegre, seria possível chegar a conclusões similares. Observe-se ainda que foram descritos os mecanismos de participação existentes em todos os hospitais próprios do Ministério da Saúde. Desse modo, não é improvável que as conclusões apresentadas na maioria dos capítulos possam alcançar certo grau de generalidade.

Uma terceira perspectiva é que, em contraste com a maioria dos estudos sobre o tema, os artigos não focalizaram a análise nos participantes 'usuários'. O conceito foi útil apenas na análise de mecanismos de participação individual em hospitais. No entanto, não foi considerado adequado para a compreensão de processos políticos que envolvem atores coletivos. Assim, por um lado, as pesquisas utilizaram os conceitos de atores estatais e societais ao se referirem àqueles que agem, em geral, representando interesses de órgãos públicos ou de governo, no caso dos primeiros, ou representando interesses de coletividades ou particulares, no caso dos segundos. Os atores societais foram divididos em dois grandes tipos: os de mercado e os sociais. Os primeiros estão associados ao conceito de sociedade civil; os segundos estão relacionados à noção de economia de mercado. Por outro lado, os estudos identificaram a existência de articulações entre atores estatais e societais, que por vezes constituíam-se como comunidades de política, que desconsideravam os limites formais entre Estado e sociedade. Tais comunidades agem em contextos de redes de políticas e são integradas por individuos que compartilham uma determinada visão sobre quais devem ser os resultados das políticas. Eles ora agem em organizações da sociedade civil ou do mercado, ora ocupam postos em instituições governamentais.

Uma quarta perspectiva inovadora de análise foi o uso de uma abordagem teórica que ressalta as relações de interdependência entre as instituições, os atores estatais e os atores societais. Assim, os estudos utilizaram as contribuições do institucionalismo histórico e das vertentes teóricas políticoinstitucional, construcionista e estratégico-relacional, ao destacar a importância não apenas de redes de relações entre atores sociais, mas também entre eles e atores estatais. Essas abordagens permitem o uso da noção de 'configuração de relações', inspirada na obra de Norbert Elias, que concebe a sociedade como algo que está sempre 'se fazendo', mudando, ainda que de forma incremental.

Informados por tais perspectivas analíticas, os capítulos permitiram que se identificasse o papel que os mecanismos de participação do Sistema 
Único de Saúde (SUS) examinados desempenham na arena política setorial. No caso dos conselhos, propiciaram o aprofundamento da compreensão das relações sociais que tais fóruns engendram em seu interior e que se irradiam na rede de relações, mais amplas, que compõem a dinâmica política setorial.

O primeiro fórum analisado, o Conselho Nacional de Saúde (CNS), foi criado em 1937, mas somente a partir de 1990 passou a ter relevância na arena decisória setorial. De 1990 a 2006, do ponto de vista legal, as funções do Conselho permaneceram as mesmas, mas o seu papel, no contexto do sistema, e a sua composição modificaram-se. Entre 1990 e 1993, o fórum posicionava-se no centro da arena política setorial. Nesse conturbado período inicial de implantação do SUS, atores governamentais, sociais e de mercado disputavam principalmente ali a ampliação de sua influência sobre os rumos da política de saúde nacional. A partir de 1993, no entanto, o Conselho deixou de ter uma posição garantida e estável no centro do processo decisório. As variações nessa posição passaram a depender, em grande parte, do modo como se estruturavam as relações entre os gestores federais de saúde e o grupo de conselheiros oriundos de entidades sociais que lideravam os trabalhos do fórum.

O lugar relativamente secundário do fórum para a construção de consensos ou explicitação de conflitos sobre temas candentes da área se deveu, em parte, à criação das comissões intergestores que, depois de 1993, constituíram-se como o principal espaço colegiado decisório e de coordenação federativa do SUS. Não apenas os gestores federais de saúde, mas também os estaduais e municipais priorizaram a atuação nessas comissões. No entanto, a posição do Conselho na arena decisória setorial foi também o resultado da estratégia adotada pelos conselheiros provenientes de entidades sociais, que hegemonizavam os trabalhos do fórum.

Entre 1990 e 2006, tanto em termos relativos como absolutos, cresceu o número de conselheiros provenientes de organizações sociais - principalmente das categorias de profissionais e trabalhadores de saúde; de entidades étnicas, de gênero e de portadores de patologias ou deficiências; e de associações comunitárias, movimentos sociais e organizações não governamentais (ONGs) - enquanto diminuiu a participação dos representantes governamentais e de mercado. Como mostra o capítulo 2, em 2005 o aumento no número de conselheiros sociais no plenário era apenas um dos indicadores de sua predominância. Além 
disso, eles eram os mais assíduos às reuniões, eram aqueles que se manifestavam com maior freqüência durante as discussões, que coordenavam a maior parte dos debates e que mais vezes representavam o Conselho em atividades externas. Havia uma preponderância relativa desses conselheiros na condução das discussões e deliberações, ante a menor participação de conselheiros governamentais e o diminuto envolvimento de representantes de organizações de mercado.

Um 'núcleo duro' de seis conselheiros provenientes de entidades sociais - formado por quatro representantes de organizações de profissionais e trabalhadores de saúde e dois de entidades étnicas, de gênero e de portadores de patologias ou deficiências - influenciava fortemente as discussões e deliberações que ocorriam no fórum. Esses conselheiros adotaram como estratégia concentrar as discussões no funcionamento do próprio fórum e no controle social no SUS e procuraram restringir a influência dos representantes de entidades de mercado, de médicos e de gestores no processo decisório do fórum. Desse modo, inadvertidamente, estimularam os últimos, que ocupavam posições centrais na arena decisória setorial, a buscar defender seus interesses e apresentar suas propostas em outros espaços politicos. Conselheiros que representavam entidades de mercado, os médicos e os gestores reduziram a sua influência no interior do fórum, mas continuaram a ocupar posições muito influentes nessa arena.

No entanto, isso não deve obscurecer o fato de que o CNS exercia importante papel no contexto da política de saúde do país, ao fiscalizar a implementação de ações e ao deliberar sobre assuntos variados. Agindo como uma instância de fiscalização da execução da política de saúde, de forma constante, ele procurava obter informações sobre as ações das instituições públicas e privadas atuantes na área. Desenvolvia ainda uma intensa atividade deliberativa, no sentido de promover a discussão pública de propostas de políticas e de programas afetos à área.

Saliente-se que o fórum desempenhava também o papel de congregar atores individuais e coletivos comprometidos com o controle social e com a defesa dos princípios fundamentais do SUS. Sob a liderança de seus membros mais atuantes, o CNS tornou-se o principal espaço de articulação com os conselhos estaduais e municipais e um dos lugares centrais de conexão entre participantes importantes da rede da política de saúde, em especial da nova comunidade de política que se formara no final dos anos 90, na área da saúde. Era o principal espaço de articulação nacional de aliados e de 
difusão de idéias e propostas da nova comunidade, que disputava com outras comunidades, marcadamente com o movimento sanitário, a condição de herdeira legítima do movimento sanitário fundador do SUS.

A análise do Conselho Estadual de Saúde do Rio Grande do Sul (CES/RS) mostrou a existência de similaridades entre o fórum nacional e o estadual. Assim como no CNS, no CES/RS, além de discutirem-se intensamente politicas e programas de saúde - especialmente aquelas relacionadas à gestão e a questões financeiras -, articulavam-se e - por meio dessa articulação - fortaleciam-se politicamente atores sociais e governamentais que defendiam a implementação de politicas de saúde que seguissem os principios estabelecidos pelas leis que instituíram o SUS. Também no CES/RS havia a predominância de representantes de entidades sociais, e os representantes de organizações de profissionais e trabalhadores de saúde destacavam-se dentre os demais participantes ao hegemonizar debates e coordenar diversas instâncias. No fórum estadual, no entanto, as conexões entre os representantes de profissionais e trabalhadores de saúde e outros atores sociais eram menos consistentes. Outra diferença era a presença maior dos gestores estaduais na condução geral dos trabalhos do CES/RS em relação ao que foi verificado no fórum nacional. No CES/RS, além de disporem dos recursos de poder inerentes à condição de gestores, eles podiam agir diretamente sobre a definição da agenda política do fórum.

Assim como no CNS, a posição dominante dos atores sociais, no interior do CES/RS, não significava que o fórum ocupasse lugar central no processo decisório setorial. A dominância no interior do Conselho era o resultado de articulações entre representantes de organizações sociais, que atuavam nos conselhos estadual, regionais e municipais de saúde, e dirigentes estaduais de saúde. No entanto, os conselheiros provenientes de entidades de mercado, cuja posição no interior do fórum era hierarquicamente inferior à dos representantes de entidades sociais e dos gestores, fora do Conselho fortaleciam-se. Para isso podiam acionar os poderes Judiciário e Legislativo e, assim, garantir que as políticas de seu interesse fossem levadas a efeito e que medidas que a elas se opusessem não viessem a se efetivar.

Também o exame dos conselhos municipais de saúde da RMPA permitiu que se constatasse que eles exerciam funções deliberativas e de fiscalização. Assim como nos fóruns nacional e estadual, o significado de deliberação relacionava-se ao modo como as decisões eram tomadas, mediante discussão e votação. A fiscalização, por sua vez, referia-se não apenas ao destino de 
verbas e ao financiamento em saúde, mas também à qualidade do atendimento prestado e às ações do gestor público.

Nos fóruns municipais era expressiva a presença de atores sociais e governamentais não apenas na composição legal dos fóruns, mas também nas suas instâncias decisórias e no processo de formação de suas agendas. Os gestores de saúde municipais definiam a infra-estrutura para o funcionamento dos fóruns, além de serem muito influentes na formulação da agenda de debates e no próprio encaminhamento dado às decisões tomadas. Os representantes de entidades sociais tinham igualmente presença marcante nas discussões que ocorriam nas plenárias, nas instâncias de direção dos fóruns e na formação das agendas de debates. Observe-se ainda que não foi possivel identificar a existência de uma articulação de atores estatais e societais que se assemelhasse a uma comunidade de política, reformista ou não, atuando no setor, no nível metropolitano.

A análise dos mecanismos participativos em hospitais do Ministério da Saúde visava apenas a descrever os mecanismos existentes. A sistematização dos resultados dessa investigação pioneira teve como mérito inserir as organizações hospitalares no âmbito dos objetos empíricos que podem ser focalizados ao se tratar do tema da participação em saúde. A pesquisa, cujos resultados foram apresentados no capítulo 5, permitiu constatar que as políticas federais, que induziam à criação e à expansão desses mecanismos, tiveram reflexos na organização e no funcionamento dos hospitais estudados. A partir de 2003, ampliou-se a participação de indivíduos e de grupos, internos e externos aos hospitais examinados, o que resultou na inclusão das visões desses individuos e grupos nos processos decisórios dessas organizações.

Uma das contribuições mais interessante que os estudos de Participação e Saúde no Brasil oferecem para o debate sobre o tema é a constatação de que atores sociais exercem uma influência decisiva sobre a dinâmica de trabalho dos fóruns. Dentre esses atores, os representantes de profissionais e trabalhadores de saúde, e mesmo os profissionais de saúde individualmente, destacam-se como os protagonistas de eventuais articulações entre atores sociais realizadas no âmbito dos conselhos, como os dirigentes de instâncias assessoras ou de coordenação, tanto nos conselhos como nos hospitais, e como os agentes políticos com presença marcante na área. Investigações futuras poderão explorar as raízes sociológicas e simbólicas do poder de tais atores que extrapola os limites das instituições de saúde, nas quais reconhecidamente eles detêm o controle técnico e político, estenden- 
do-se também para os espaços participativos nos quais disputam com os atores governamentais a definição da agenda de debates e possibilidade de formular propostas de políticas para a área.

As conclusões apresentadas pelos estudos sobre as ações, as posições e o nível de influência de atores estatais e societais nos mecanismos participativos examinados - e sobre como tais mecanismos afetam a arena decisória da área da saúde - poderão estimular novas pesquisas sobre a temática que avancem no sentido de enriquecer os recursos teóricos e de método à disposição dos analistas. Porém, a expectativa mais ambiciosa dos autores que integraram o esforço de pesquisa empírica e o processo de elaboração dos textos aqui reunidos é de que as análises contribuam para que os atores politicos diretamente envolvidos na arena politica da área da saúde, particularmente aqueles que participam dos conselhos ou que estão envolvidos com a implantação de outros mecanismos participativos, reflitam sobre suas ações e sobre as condições institucionais em que elas se desenvolvem. Esse é o ponto de partida para a construção de estratégias de ação que favoreçam, de fato, a democratização da gestão em saúde do Brasil e, principalmente, que viabilizem a realização, ainda que parcial, dos objetivos que inspiraram a construção do SUS no país. 

Formato: $16 \times 23 \mathrm{~cm}$

Tipologia: Goudy Old Style e Century Gothic

Papel: Pólen $70 \mathrm{~g} / \mathrm{m}^{2}$ (miolo)

Cartão supremo $250 \mathrm{~g} / \mathrm{m}^{2}$ (capa)

CTP, impressão e acabamento: Imprinta Express Gráfica e Editora Ltda.

Rio de Janeiro, julho de 2009.

Não encontrando nossos títulos em livrarias, contactar:

EDITORA FIOCRUZ

editora@fiocruz.br | www.fiocruz.br/editora 
